
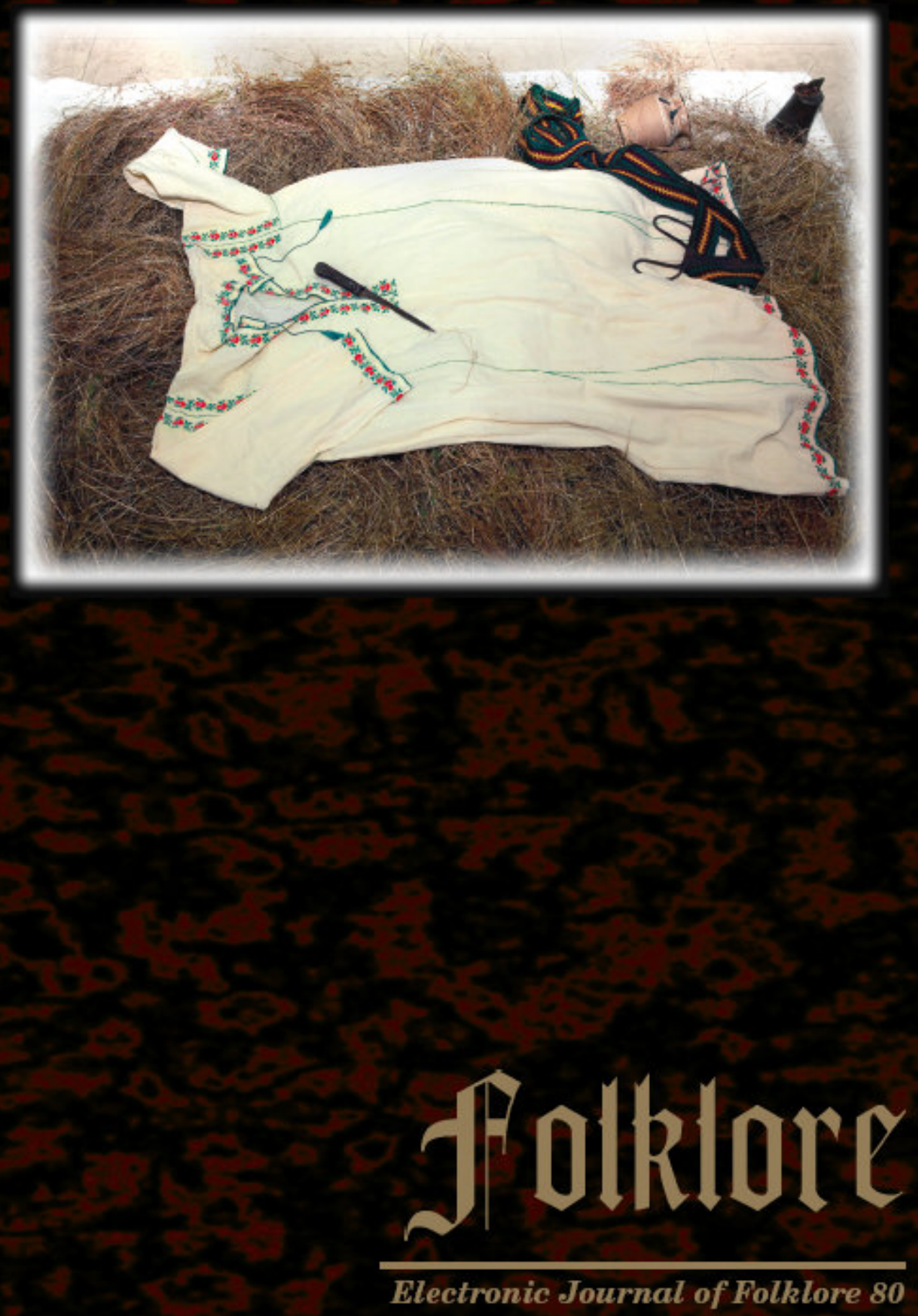


\section{Folklore}

Electronic Journal of Folklore http://www.folklore.ee/folklore Vol. 80

2020 
Folk Belief and Media Group

of the Estonian Literary Museum

Estonian Institute of Folklore

\section{Folklore}

Electronic Journal of Folklore

Vol. 80

Edited by Mare Kõiva \& Andres Kuperjanov

Guest editors Irina Sedakova \& Nina Vlaskina

ELM Scholarly Press

Tartu 2020 


$\begin{array}{ll}\text { Editor in chief } & \text { Mare Kõiva } \\ \text { Co-editor } & \text { Andres Kuperjanov } \\ \text { Guest editors } & \text { Irina Sedakova \& Nina Vlaskina } \\ \text { Copy editor } & \text { Tiina Mällo } \\ \text { News and reviews } & \text { Piret Voolaid } \\ \text { Design } & \text { Andres Kuperjanov } \\ \text { Layout } & \text { Diana Kahre }\end{array}$

Editorial board 2015-2020: Dan Ben-Amos (University of Pennsylvania, USA), Larisa Fialkova (University of Haifa, Israel), Diane Goldstein (Indiana University, USA), Terry Gunnell (University of Iceland), Jawaharlal Handoo (University of Mysore, India), Frank Korom (Boston University, USA), Jurij Fikfak (Institute of Slovenian Ethnology), Ülo Valk (University of Tartu, Estonia), Wolfgang Mieder (University of Vermont, USA), Irina Sedakova (Russian Academy of Sciences).

The journal is supported by the research grant of the Estonian Literary Museum EKM 8-2/20/3 and by the Centre of Excellence in Estonian Studies (TK 145) through the European Regional Development Fund.

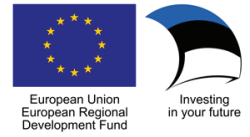

Indexed in EBSCO Publishing Humanities International Complete, Clarivate Analytics Web of Science (Arts \& Humanities Citation Index), MLA International Bibliography, Ulrich's Periodicals Directory, Internationale Volkskundliche Bibliographie / International Folklore Bibliography / Bibliographie Internationale d'Ethnologie, Open Folklore, C.E.E.O.L., Scopus

\section{Editorial address:}

Folklore: Electronic Journal of Folklore

Vanemuise 42-235

51003 Tartu

Estonia

phone: $\quad+3727377740$

fax: $\quad+3727377706$

e-mail: folklore@folklore.ee

home page: http://www.folklore.ee/folklore

All rights reserved

(C) Estonian Literary Museum

Estonian Institute of Folklore

Authors

Design Andres Kuperjanov

According to Creative Commons licence BY-NC-ND 4.0

ISSN 1406-0957

doi:10.7592/FEJF2020.80 


\section{CONTENTS}

Birthlore and Childhood in Archaic and Modern European Cultures:

An Introduction

Irina Sedakova, Nina Vlaskina

Rituals of Social Legitimization in the Lithuanian Childbirth Customs System: Traditions and Innovations

Rasa Paukštytè-Šaknienè

The Structure and Genesis of One Type of Magic Spell against

Children's Insomnia among Slavic Peoples

Tatiana Agapkina, Andrei Toporkov

Unlived Life: The Death and Funeral of a Child in Slavic Traditional Culture

Irina Sedakova

Child in the Natal Narratives of Modern Ukrainian Mothers:

Folkloric Symbols and Frequent Motifs

Oksana Labashchuk, Halyna Derkach, Tetiana Reshetukha

"How I Gave Birth" (and Why I Am Writing about It): Women's Narratives of First Childbirth Experiences from Internet

Publications

Natalia Gramatchikova

The Birth of a Child as Experienced and Narrated in the 1990s Finland

Lena Marander-Eklund

The Rite of Male Circumcision among the Muslim Population in the Western Balkans

Alexander Novik 
A Local Midwife or a Doctor? Two Systems of Knowledge in Birthing Practices of Russian Old Believers

Natalia Dushakova

Taking Hold of the Future: Active Childbirth Practices and Beliefs in Romania (in the Home Country and in Migration)

Adina Hulubaş

"Coming into the World: From Spirits to the Spirit". The First Childhood Museum in Romania

Anamaria Iuga

REview Essay

Jews in the Russian Empire, the Soviet Union, and the Russian

Federation

Anastasia Kharlamova, Alexander Novik

News IN BRIEF

Joint Estonian-Belarusian Webinar "Mission Possible V: Adaptations,

Transformations, and Fundamental Aspects of Vernacular Culture”.

Anastasiya Fiadotava

Book Reviews

Slavic Arboretum in the Light of Ethnolinguistics. Irina Sedakova 


\section{BIRTHLORE AND CHILDHOOD IN ARCHAIC AND MODERN EUROPEAN CULTURES: AN INTRODUCTION}

\section{Irina Sedakova}

Sc.D., Head of the Department for Typology and Comparative Linguistics

Institute for Slavic Studies, Russian Academy of Sciences, Russia

irina.a.sedakova@gmail.com

\section{Nina Vlaskina}

PhD, Senior Research Fellow

Southern Scientific Centre, Russian Academy of Sciences, Russia

nvlaskina@gmail.com

This issue is dedicated to a topic which has always been and will be of utmost interest to scholars of many humanitarian and social disciplines as well as of medical science. At the heart of this subject is an event which is both physical (natural, ontological) and symbolical in nature - the miracle of childbirth. It denotes and alludes to the origin and beginning of life, initiation and acquisition of a new status. As such it has been thoroughly studied by ethnographers, ethnologists, cultural and medical anthropologists, historians, sociologists and theologians, linguists and folklorists, psychologists and pedagogues from various countries. In the twenty-first century, with the advent of new technology and research methods, together with huge advances made in medical care for women, academic studies of childbirth and early childhood became multidisciplinary. Even so, the canonical works and traditional worldview concepts - mostly typical for rural spaces that had been introduced by classical scholars such as Victor Turner, Bronislaw Malinowski, Arnold van Gennep, and many others - are the backbone and foundation of any study. Archaic views on pregnancy, delivery, and the baby's initial socialisation, which do not seem at first glance to be applicable in the most modern urban settings equipped with modern medical and scientific facilities, prove to be amazingly stable. Parallel to this continuation of tradition is a new attitude to the personal life and emotions - a "new sincerity". This contrasts with the popular principles of secretive behaviour of the mother-to-be. Many stories about women's experiences of delivery posted 
on the Internet give scholars new insight into the material and open it up to a multidisciplinary analysis.

We aligned the articles according to the methodological principles and the kind of material the authors have used. The first two articles, one by Rasa Paukštytè-Šaknienè (Lithuania), "Rituals of social legitimization in the Lithuanian childbirth customs system: Traditions and innovations", and the other by Tatiana Agapkina and Andrei Toporkov (Russia), "The structure and genesis of one type of magic spell against children's insomnia among Slavic peoples", use diachronic methods. Though the first article covers the ritual practice of Lithuanian regions, and the second one sheds light on Slavic charms, the authors of the two studies start their research from old written texts. Then they compare them with corresponding oral versions and their modifications documented in modern times. Such a method allows the researchers to define the genesis of certain elements of the rituals or texts, to draw parallels inside the tradition(s), and to detect most stable points in the whole corpus.

Irina Sedakova (Russia) in her article "Unlived life: The death and funeral of a child in Slavic traditional culture" employs the ethnolinguistic approach, investigating the central theme - the premature death - with the help of linguistic, folklore, and ethnographic data. This complex methodology shows the tragic event as part of the family scenario and as a result of intricate reasons: God's will, the fate, the verdict of the Fates, parents' ban on the rules and lack of veneration of the saints, black magic, the evil eye, curse, etc. The dead child is seen as a small deceased human being who has not passed through all the stages of life, as an angel and as a kin's patron, one of the ancestries.

The next series of articles focus on modern narrations and narrative style. Oksana Labashchuk, Halyna Derkach, and Tetiana Reshetukha (Ukraine) and Lena Marander-Eklund (Finland) have put down interlocutors' stories about the experience in giving birth. The authors explicate different possibilities of the methodology of these texts-clichés. The Ukrainian scholars concentrate their attention on the child to be born and then the newly born baby. They find archaic themes and parallels in the modern depiction of the movements of a child in the womb and its appearance, which prove that the fundamental ideas have survived until nowadays. Lena Marander-Eklund highlights dramatic narrative means and stylistics; she describes the transformation of emotions during the interview, and portrays the anthropological vision of the body. Similar aspects are at the heart of Natalia Gramatchikova's study: showing the structure of the narrative and body experience, she touches upon other social issues like aggression, pain, and helplessness of the women in the maternity medical system. The scholar investigates different types of narratives - they are not a dialogue or an interview, but are mostly monologues, posted on the Internet for various 
reasons as self-expression and auto-reflection. These articles exemplify different research strategies as related to the material. Lena Marander-Eklund focuses on the narratives on childbirth, analysing deep interviews with 14 mothers who have had their first baby. She interviews them several times before the labour and after it, comparing their emotions and perception of the processes. Oksana Labashchuk, Halyna Derkach, and Tetiana Reshetukha have compiled a base of 500 non-structured interviews, which allows them to unravel the most frequent motifs and stable elements of the narratives. Natalia Gramatchikova also works with 'big data'; she does not communicate with the authors of the narratives, who are geographically dispersed in the Russian cities and in migration. Even more, it is difficult to determine the location. The major aim of these narratives is to verbalise the events, to mentor those who do not have this experience and knowledge of the Russian maternity hospitals.

Two articles by Alexander Novik (Russia), "Rite of male circumcision among the Muslim population in the Western Balkans", and by Natalia Dushakova (Russia), "A local midwife or a doctor? Two systems of knowledge in birthing practices of Russian Old Believers", discuss the transformation of the traditional culture under the pressure of the medical developments. Alexander Novik examines the shift of traditional ritual practice of circumcision from the jurisdiction of religious officials to the hospital, since circumcision is now performed by surgeons. He places the rite of circumcision in a broad cultural and geographical context and shows how the traditional Muslim society adopts technical progress and legitimises it. Natalia Dushakova's focus is on the issue of transition from home birth to hospital birth. She examines the symbolic and pragmatic functions of a midwife, the modern transformation of her role due to the fact that women are taken to hospitals to give birth, and the adaptation of the community to the new system of maternity care. The author collected her field material among Old Believers - the Slavs who today live in Moldova and in the Danube Delta in Romania.

Romanian material is presented in the following two articles by Adina Hulubas,, "Taking hold of the future: Active childbirth practices and beliefs in Romania (in the home country and in migration)", and Anamaria Iuga, "'Coming into the world: From spirits to the Spirit'. The first childhood museum in Romania". These two authors demonstrate how the topic of childbirth can be studied and exhibited in the city. Adina Hulubas analyses the ideas and practices related to pregnancy and the first year of a child's life (baptism, first bathing, fortune-telling about the future during the first haircut). Her interlocutors are Romanian women who live in the homeland or abroad. She identifies traditional rural symbols and patterns of behaviour in the life of city dwellers. The issue ends up with the article by Anamaria Iuga, who literally shows to 
the readers the museum representation of Romanian rituals of childbirth and early childhood. This experimental exhibition aims to embody intangible objects in material form. These ideas, beliefs, and ritual acts make up the 'fabric' of the birthlore and appeal to the emotions and feelings of the audience. Similar to other articles in the issue, this study proves that emotions and experiences are central to the episode of childbirth in many ways.

We hope the issue will provide new material and methods to the readers and will inspire them to work on similar topics.

Irina Sedakova, PhD, Sc.D., is Head of the Department for Typology and Comparative Linguistics, Institute for Slavic Studies, Russian Academy of Sciences. Her fields of interest are Slavic and Balkan studies, ethnolinguistics, sociolinguistics, folklore, childbirth and calendric customs.

irina.a.sedakova@gmail.com

Nina Vlaskina, PhD, is Senior Research Fellow at the Southern Scientific Centre of the Russian Academy of Sciences. Her research interests primarily concern traditional culture of the Don Cossacks and Old Believers of the Southern Russia.

nvlaskina@gmail.com 


\title{
RITUALS OF SOCIAL LEGITIMIZATION IN THE LITHUANIAN CHILDBIRTH CUSTOMS SYSTEM: TRADITIONS AND INNOVATIONS
}

\author{
Rasa Paukštytè-Šaknienè \\ PhD, Senior Research Fellow \\ Department of Ethnology and Anthropology \\ Lithuanian Institute of History \\ Vilnius, Lithuania \\ rasa.sakniene@gmail.com
}

\begin{abstract}
By comparing data of the descriptions of birth customs of Lithuania Minor at the end of the seventeenth century and personal fieldwork data collected in the villages and small towns of south-eastern Lithuania (Dzūkija ethnographic region) in 1992-2007, I discuss the problem of modernization of Lithuanian culture through the diachronic change of structural elements of the birth cycle performed after the birth of a child. I distinguish the three consecutive stages in the cycle of birth customs - the first visit to the baby and the mother (lankynos), baptism, and churching of the woman - and make an attempt to reveal changes in them in the twentieth and early twenty-first centuries in terms of historical development, chronological duration, and social interaction.
\end{abstract}

Keywords: baptism, contemporary society, cycle of birth customs, Lithuania Minor, social changes, south-eastern Lithuania

\section{INTRODUCTION}

Rituals in a person's life cycle reveal and mark the most important moments in their life, including the birth and socio-cultural legitimization of the baby. As Ronald L. Grimes mentioned, "Even a single rite of passage can divide a person's life into 'before' and 'after'. An entire system of such rites organizes a life into stages. These ceremonial occasions inscribe images into the memories of participants, and they etch values into the cornerstones of social institutions" (Grimes 2000: 5). The cycle of birth customs in the Lithuanian village in the late nineteenth-early twentieth centuries began with the woman falling pregnant, and ended with a ritualized return to regular social life after giving birth. Throughout this period, the woman acquired a special status in 
the family and village community (Paukštyte 1999). As research has shown, the ethnic factor plays a minimal role in the cycle of birth customs. According to Natalia Gratsianskaia and Aleksandr Kozhanovskii, compared to birth cycle customs in other European countries, unique features cannot even be noticed in Slavic nations whose ethno-cultural specifics in other topics are often widely declared (Gratsianskaia \& Kozhanovskii 1999 [1997]: 515). The customs associated with the social legitimization of a child's birth span the first months of his or her life, rarely going beyond a year. One of the most important acts of a child's social legitimization was and still is baptism, which is the most fundamental Christian rite of passage. It is one of the additional rituals which Christianity brings to the catalogue of rites performed by the humanity in the normal course of human life. By the use of water and in the name of the Holy Trinity, a person becomes a member of the Church (Davies 1994: 41-42). On the other hand, baptism has been not only a church sacrament but also a social act. ${ }^{1}$ This ritual constructed neighbourhood, community, and extended family bonds, while also carrying religious meaning for the child, family, and parish (Cressy 1999 [1997]: 149).

When analysing the life cycle of a person, Arnold van Gennep's "passage rites" theory from 1909 is still the most often cited reference point, which distinguishes three structural functional types of rituals that mark changes in the social status: rites of separation, transition rites, and rites of incorporation (Gennep 1960 [1909]: 11). Yet, this ritual theory often helps ascertain similarities in cultural characteristics rather than model how they change; nonetheless, it is an excellent instrument for revealing the structure of transition rituals, facilitating their diachronic comparison in relation to the social processes surrounding the ritual. According to Ursula Rao, "Ritual is seen as a medium for the integration of society. Interestingly, this idea remains important even where attention is shifted to conflict and change" (Rao 2006: 145).

The earliest sources describing the life led by the Baltic tribes show that people opposed Christian baptism and even tried to erase it by conducting home-based rituals (Paukštytė-Šaknienè 2009: 164-165), but ever since the baptism of Lithuania (in the late fourteenth-early fifteenth centuries) it was the church baptism that dominated and carried legal power. Up until the Soviet occupation, a person's birth, marriage, and death were legitimized in church across most of Lithuania. Besides, the ritual should not necessarily be related to religion or an archaic society (Grimes 2013). I would agree with the idea of Pascal Lardellier that all human societies are matrices of rituals. They permanently nourish social cohesion in their materiality and symbolism (Lardellier 2019: XXI). From 1945, church registry no longer carried any legal power, and baptism in church became unacceptable in Lithuania. ${ }^{2}$ Meanwhile, with the 
introduction of civil name-giving (in 1962), people still ignored the non-religious ritual in all manner of ways, often adding a Christian ritual in secret, i.e., by performing baptism before or after the secular name-giving. The social links to the local community and extended family were established during both of these rituals, which could have been different in each community or even in individual families.

This prompted me to analyse the socio-cultural acknowledgement rituals associated with a person's birth in Lithuania in two "critical" periods: the formation of the Christian legitimization ritual in the case of a child's birth, and the implementation of the socialist name-giving ritual. The aim of the first one was to replace pre-Christian rituals with Christian ones, while the second one was supposed to replace Christian rituals with secular ones. ${ }^{3}$ Looking at birth rituals from the perspective of the woman (from pregnancy to the return to "normal" life after giving birth) and the child (from birth to its socio-cultural legitimization), they consist of Church and/or state-regulated rituals as well as those based on folk beliefs and community traditions, whose interaction changes in the perspective of time. These rituals add significance to one or another element in the cycle of birth customs.

Many ethnologists who conduct diachronic cultural research prioritize the ethnographic field research method in their investigation. Undoubtedly, the potential of ethnographic field research allows us to focus on the situation in the twentieth century, while descriptions of birth cycle customs from the sixteenth-seventeenth centuries and earlier periods can be analysed only based on the available written sources. Their reliability is inconsistent as the authors did not always know Lithuanian, and they might not have had the chance to observe a specific community for themselves, and/or personal motives might have swayed them from presenting an objective image of life at the time.

In order to compare the seventeenth-century birth cycle customs with those from the twentieth century, the situation in two Lithuanian regions had to be compared. Most of the data about the earliest Lithuanian birth customs comes from Lithuania Minor. ${ }^{4}$ As the local population from this region had practically disappeared by the second half of the twentieth century, the Dzūkija ethnographic region in south-eastern Lithuania, where birth cycle customs in this period had retained the most traditional cultural elements, was selected for field research. The historical context and natural environment pre-determined a slower modernization of this region (as compared to other Lithuanian regions).

On the other hand, old written sources (seventeenth century and earlier) do not reveal birth rituals related to a woman's pregnancy or the birth itself. Therefore, I will limit myself to the analysis of the customs and rituals of social 
legitimization performed after the birth of a baby, which covers only a part of the cycle of birth customs.

Based on these provisions, the aim is to analyse diachronic changes of rituals of a child's social legitimization in the Lithuanian childbirth customs system in terms of the socio-cultural aspect. By using personal field research results and published ethnographic accounts, I shall aim to: 1) analyse the implementation of Christian baptism and the functioning of the child's social legitimization customs at the end of the seventeenth century; 2) reveal the customs and rituals related to the birth of a child in the twentieth-beginning of the twenty-first century; 3 ) analyse the duration and stability of baptism and lankynos (visiting of the baby and mother) in the perspective of history; 4) reveal changes in social interaction in the customs of baptism and lankynos.

The most comprehensive local ethnological research of contemporary birth customs in Dzūkija (spanning the second half of the twentieth century) was the research I conducted in the Merkinè (Varèna district) area in 2000-2001, with the results published in two articles (Paukštytė-Šaknienè 2002a; 2002b). Later, other locations in Dzūkija were similarly studied. In 2006-2007, I conducted research of baptism customs across 24 locations in this region, which encompassed the situation from the last quarter of the twentieth century to the beginning of the twenty-first century (Paukštytė-Šakniene et al. 2009).

Birth customs research by other authors conducted in the late nineteenthmid-twentieth centuries is important for the diachronic analysis. Among the publications dedicated to Dzūkija, I would distinguish the study by Vincas Krèvè-Mickevičius on the late nineteenth-early twentieth centuries (KrèvèMickevičius 1933). This is probably the most thorough study of baptism customs to have been made in the inter-war years (1918-1940), which helps us understand the traditional customs of the $d z \bar{u} k a i$ (the locals of this region) and remains significant to this day.

The regional particularities of birth customs in Lithuania were examined in monographs by me (Paukštytė 1995 (second edition Paukštytė-Šaknienė 2008); Paukštytè 1999) and Rasa Račiūnaitè (2002).

In order to understand the birth customs of the twentieth century in the perspective of time, the earliest sources testifying to their existence must be analysed. Of the earliest written sources, I would highlight the book by Theodor Lepner (Theodoras Lepneris), titled Der Preusche Littauer, which could be considered the first Lithuanian local ethnographic monograph, with a whole chapter dedicated to baptism (out of the total of 15). The author collected data from the local population starting in 1665, when he was serving as a priest in the Būdviečiai parish in the Ragainè (Ragnit) district, and wrote the book in 1690 (the first edition was published only in 1744) (see Lepner 1744; Lepneris 
2011). Baptism from around the same period was also described by Matthaeus Praetorius (Matas Pretorijus). The material was based on his findings in the Nybūdžiai parish in the İsrūtis (Insterburg) district, with data for comparison from other locales in Lithuania Minor (the final draft was prepared before 1699) (Pretorijus 2006: 644-657).

In addition, attention should also be turned to the situation in 1940-1990, when religious baptism was no longer tolerated and a non-religious "namegiving" ritual was being intensively formed and implemented. I have analysed the Soviet name-giving rituals in several papers, and also published a comprehensive article on this theme (Paukštytè-Šaknienè 2007).

\section{THE IMPLEMENTATION OF CHRISTIAN BAPTISM AND THE FUNCTIONING OF THE CHILD'S SOCIAL LEGITIMIZATION CUSTOMS AT THE END OF THE SEVENTEENTH CENTURY}

Lithuania was one of the last countries to adopt Christianity in Europe. Part of the Grand Duchy of Lithuania became Christian in 1387, while the western lands - Samogitia - were Christianized in 1413. In the nearby territories in Latvia and Prussia, inhabited by the Balts, this process had taken place several centuries earlier.

The earliest sources describing Baltic tribal culture testify to a forced implementation of Christian baptism. The Teutonic Order's peace treaty of 1249 with the Pomesanian, Warmian, and Notangian Prussians reveals the radical measures used to introduce baptism. The treaty explains how a newborn had to be baptized within no more than eight days, and those who were not baptized within that time had a month, after which time they would have their property confiscated and be driven out beyond the Christian lands (Vèlius 1996: 241-242). Baptism was rather difficult to implement as, for example, the events from the late twelfth-early thirteenth centuries described in the Livonian Chronicle of Henry tell us that Christian baptism could be washed away with river water (ibid.: 285). This fact is confirmed by later sources as well. The decree of the Sambian bishop Michael Jung (believed to have been written in 1426) indicates that children baptized by Christian clergymen could not be re-baptized in rivers or elsewhere, or change the names given to them at baptism. Violators of this decree were threatened with fines or lashings (ibid.: 483).

A source from 1647 reveals the motives behind re-baptism and granting another name in Livonia: “... if they remained unsettled for six weeks after being baptized, they would secretly re-baptize them and give them another name, believing that the child was so irritated and could not settle because 
it had received an unsuitable or uncomfortable name" (Vèlius 2003: 679). We can come to understand the birth customs of the early Lithuanians based on sources from Lithuania Minor, which presented more thorough data from the seventeenth-eighteenth centuries as well. An analysis of sources from that time and later birth customs from Lithuania Minor form the assumption that the goal was to baptize an infant as soon as possible (fearing that an unbaptized newborn would otherwise die, and the prevailing folk belief that an unbaptized infant was not protected from harm) and the self-inscribed honour to be chosen as godparents or the expectation to arrange an as large as possible baptism feast were not necessarily related to the Christian ritual. The unique features of the folk understanding of baptism were determined by beliefs that had been around for centuries and had nothing in common with Christian ideology. The analysis of early written sources proved that the cultural uniqueness of Lithuania Minor is important in order to reveal the birth customs in this and other regions around Lithuania (Paukštytè-Šaknienè 2011: 10-12).

A more complete overview of Lithuanians' birth rites can be reconstructed from the data in Lepner's late seventeenth-century work titled Der Preusche Littauer, in the chapter "On Lithuanian baptisms", and the summary that follows, "The baptism feast is odd, there are so many Lithuanian women involved". The chapter begins with a description of the situation up to the baptism:

Sometimes the woman blessed with child in her womb asks the priest to pray for her and her unborn child in church. When the infant enters this world, the parents make an announcement to others in their household and to neighbours that the šešauninke [henceforth translated as the newborn's mother - RPŠ] has given birth and that they are invited to come over and are offered vodka (if they have some) as well as other drinks and food. The neighbouring women and close relatives who are invited bring the newborn's mother flat crackers and eggs, and this feast, which can last for a shorter or longer time depending on how much there is to eat and drink, they call rodynas. ${ }^{5}$ The kūmai (godparents) (of which there are usually three or even five) are invited to the rodynas, which is organized by the father if he is at home, or in other cases - by someone else. (Lepneris 2011: 159)

After this feast, the infant was taken to be baptized. When the infant was baptized and everyone returned home, another round of feasting was usually held where only women participated. The midwife would kill a chicken on the spot where the child was born or nearby. The newborn's mother would have to pluck that chicken in the house or nearby, and leave the feathers to lie where they were. The midwife would boil this chicken, adding mutton, pork or some 
other kind of meat to the broth. Kneeling to say a prayer before having this feast, some women would call upon the Virgin Mary "to help the mother and infant". The women would begin their feast with a drink. When the midwife would take a drink from a large cup whilst kneeling, the other women would do likewise. Before drinking, each woman had to say the Our Father prayer. Then they would eat the boiled chicken and other meat and have some more drinks. However, this feast was not intended for women who had not given birth, or men. When they had finished, the bones would be wrapped into a cloth and dug into the ground where the chicken had been slaughtered; then they would say another prayer, and drink to the health of each other and the men sitting at another table. Six weeks later, women and the godparents would come to the infant's mother and they would all go to church. ${ }^{6}$ After church, they would gather again for another feast (Lepneris 2011: 160-161).

Lepner's description indicates such parts of the birth customs as the first visiting of the baby and the mother, the baptism and the presentation at church ("churching"), known as of the late nineteenth-early twentieth centuries. However, the baptism feast would be divided into two parts: 1) a feast just for those women who had given birth themselves, and 2) a feast set up at another table for women who had not given birth, and for men.

Another description analysing the period portrayed also by Praetorius gives a somewhat different account of the visiting ("showing the baby"). This account mentions a ritualized round of drinking and eating by the midwife and the newborn's mother and father. There would also be a sacrifice made to the goddess Žemyna ${ }^{7}$, and a prayer to the goddess Laima (Layme) ${ }^{8}$ or the Virgin Mary. Guests would be at a different table and be given different foods. When the godparents arrived, drinking and eating would continue with them, yet even the beer could not come from the same barrel that the newborn's mother had drunk (together with the midwife and father). When the child was taken away for baptism, the midwife would kill a chicken with a ladle, and cook it to be eaten only by the godmothers. However, instead of being presented at the church as mentioned by Lepner, a hair-cutting rite was performed:

...That would not be all - several weeks later (some would do this after several years), the godparents would be invited back and during a special ritual the child would be given over to the most respected godparent; they would pray and drink from a filled cup. Then this godparent would take the child on the knees and cut the hair off its head; the hair would usually be placed into a cup with the godparent saying a prayer above it, then they would drink the contents of the cup, the beer and hair, and they would have to give the family a gift, for example, a shirt or something; this person 
would be highly respected by all; by doing this the parents would buy back their child from the godparent, so to speak; some would repeat the haircutting rite mentioned above several times. (Pretorijus 2006: 653-657)

The ritualized hair-cutting used to be performed among the Eastern Slavs as recently as the end of the nineteenth century. The ritual would be performed on children one year old or older (Zelenin 1991: 331). ${ }^{9}$ Children of a similar age (even up to three years old) used to have their first haircut this way in eastern Lithuania in the late nineteenth century, believing that this would make them more intelligent and help start talking sooner (Balys 2004: 51). Around the same time analogous beliefs were known in Poland as well (Gantskaia 1999: 16). However, unlike in Lithuania Minor, the first haircut in Poland was not related to birth rituals and did not make up a separate part of the birth customs cycle.

An even earlier source tells us of the reliability of the hair-cutting rite. The German-Lithuanian dictionary (Clavis Germanico-Lithvana) by Fridericus Praetorius the Elder released in around 1680 indicates:

The Lithuanians used to have a custom where, when the child was already a few weeks old, another feast would be held during which a woman (not a man) would be invited to be a godparent: this godmother would cut the child's hair above a bowl or a pitcher filled with a drink and covered with a cloth, or, as they used to call it, a veil for catching the cut hair. Then she would throw in as much money as she could spare and this donation would be called "apgelai". After that, she would take the veil out of the drink and squeeze the liquid away, then the new godmother and the infant's mother would both drink from the bowl or the pitcher. This ritual would protect the child from water and fire and ensure a healthy head of hair. The cut hair would be dug under a hop pole.... Thus, becoming a godparent was known as "apgèlu, apgèlau, apgèlèsu, apgèlèti”. (Vèlius 2003: 96-97)

The notion "new godmother" or "new baptism mother" presumes the fact of practising pre-Christian elements of baptism, or even of attempts at repeating or overriding the Christian baptism. ${ }^{10}$ The purpose of this act was to protect the infant from fire and water. The combination of the ritual act with a seemingly unimportant aim, to ensure a healthy head of hair for the child, would indicate a reduction in the sacredness of the apgèlai rite. German ethnologist Elard Hugo Meyer believed that the German baptism was a synthesis of pagan ancient Germanic and Christian customs (Filimonova 1999 [1997]: 174). It appears that a similar situation can be observed in Lithuania Minor in the seventeenth century. The accounts presented here reveal associations with both Christian (Mary) and pre-Christian (Žemyna, Laima) guardians of infants. The available material reveals the following order of birth customs performed after the birth 
of the baby: the first visiting of the baby and mother (rodynos) $\rightarrow$ baptism $\rightarrow$ ritual cutting of the hair (apgèlai) $\longrightarrow$ "churching" (i.e., presentation at church).

These customs were reinforced through rituals where the main participants and actors were women. As we can guess from several accounts from the late seventeenth century, the ritual functions of women were narrowed down (e.g. the case of cutting the infant's hair).

The rodynos (radynos) and apgelai terms mentioned in the accounts functioned in Lithuania in the late nineteenth and mid-twentieth centuries. The concept of radynos as the custom of visiting the newborn's mother was known in south-eastern Lithuania, but in this territory the word could have also meant the fact of the child's birth (Vyšniauskaitè 1964: 466). The word apgèlai was used in eastern Lithuania as well, yet not in the sense of cutting hair but to signify the visiting of the infant's mother (Balys 2004: 31-32). This is evident from the relations between customs in Lithuania Minor and Dzūkija, even though a distance of over 300 kilometres separated these lands, and a whole three centuries - the rituals themselves. On the other hand, in the perspective of time and territory, we can see a change in the birth cycle custom titles. Rodynos (radynos) referred to visiting the infant (both in the seventeenth and twentieth centuries) and the infant's birth (twentieth century), whereas apgèlai signified the cutting of the baby's hair (seventeenth century) and visiting the baby (twentieth century). This shows a possible dynamics in the structure of the birth customs cycle, which I shall analyse in the chapters below.

\section{CUSTOMS AND RITUALS RELATED TO THE BIRTH OF A CHILD FROM THE BEGINNING OF THE TWENTIETH CENTURY TO THE BEGINNING OF THE TWENTY-FIRST CENTURY}

Pregnancy was a state which distinguished the mother, or a woman who had given birth, from other women and obliged her to adhere to certain inherited customs related to the infant's life and future. Up until the mid-twentieth century, women would be assisted during childbirth by a midwife. Her duty was to make giving birth easier, to perform a ritual cleansing of the newborn and handle the placenta, as well as take care of the mother and the infant. In addition, it was believed that the midwife looked after the infant's current state but would also perform rituals to try to determine his or her future. Immediately after birth, the newborn and the mother would be visited by the local women. This custom was a display of the village community's attention and assistance. Traditionally, the ultimate social legitimization of the newborn's existence was baptism. In the late nineteenth-first half of the twentieth centuries, baptism 
consisted of two parts: baptism in church and in line with secular customs. During these rituals, the newborn was introduced into the religious and village community (with the help of godparents, the midwife, parents, and guests). The end of the cycle of birth customs was marked by the mother's "churching", or presentation at church (in some places, she would be presented at the sauna as well). After the ritual rites in the church, the woman would return to regular village community life (previous taboos were now lifted: she could walk across strangers' fields, go to the common village bathhouse and attend church services) (Paukštytè 1999).

All of these stages were related to the woman's obligations towards her child, her family, the village and the church communities, and also to the care and control exerted by the afore-mentioned institutions. This social interaction formed the cycle of birth customs and stopped people from losing sight of the ideal lifestyle model propagated at that time. How did this model change in the second half of the twentieth-early twenty-first centuries?

When we observe the transformation of the cycle of birth customs in the twentieth century, we notice rapid changes in the traditional cycle. This includes the transformation or change of the customs of baptism and the rituals of the first visit of the baby and the mother. The radical shifts to the structural elements of birth customs depended not only on political and ideological circumstances (Soviet occupation and the atheist policies of the occupant regime) but on reforms within the Church itself. In the second half of the twentieth century, we see the disappearance of the presentation at the church (churching), which marked the end of the birth customs cycle and the mother's return to regular social life. Up to the point of her presentation at church, Lithuanians and other nations would consider the woman "unclean", and capable of harming the welfare of the neighbours (Balys 1979: 41-42). The function of concluding the cycle of birth customs was now performed by the increasingly delayed baptism (it was no longer associated with the return to the "not dangerous" state of the mother). However, during the Soviet period, this church sacrament was often given in secret.

Secular life cycle rituals were developed and introduced in many countries in order to complement or replace the Christian rituals (Roth \& Roth 1990: 114). The history of the Lithuanian name-giving ceremony is very simple. In 1962 the first model name-giving event was organized at the community centre (called culture house) of the "Aušra" collective farm in Kaunas district. At the request of the Culture Department of the Lithuanian SSR, the ceremony was filed officially to provide methodological guidance for culture and education workers authorized to organize such festivities in their local residential districts. A study on Lithuanian family traditions published by Angelè Vyšniauskaitė in 1967 
mentions that as early as in the 1st half of 1963 name-giving guidelines were introduced in many Lithuanian regions at the suggestion of residential district authorities. By 1965 "the name-giving tradition had become universally present in towns and collectivized villages of Soviet Lithuania" (Vyšniauskaitè 1967: 57-58). However, the Soviet regime failed to empower the newly created ritual of name-giving even though definite borrowings from the ritual of baptism and even wedding customs were used in it. Certain ritual functions were prescribed for the newborn's grandmother, who replaced the "old lady" (the midwife). As per the living traditions in Lithuanian village weddings, it was suggested to create "blocks" (a barrier to passage mostly made of wood) when welcoming the name-parents, or to organize "imposter name-parents" to take the place of the real name-parents at the dinner table, and so on (Paukštytè-Šaknienè 2014: 60). Parents with a higher social status, who carried more responsibility in the eyes of the community and the authorities, were offered the alternative of ending the cycle of birth customs with a civil name-giving ceremony. Thus, left with this choice, the birth customs cycle could be ended with a civil namegiving. As I already mentioned, often after this official name-giving ceremony the same infant would be baptized in church (or the other way round), while the celebration reinforcing the birth of the child would be the party at the parents' home attended by the participants in both the civil and religious acts. Babies were commonly taken to church for the baptism ritual either before or after the civil name-giving ceremony. For example, in the Merkine area, in most cases the godparents and name-parents were the same individuals. But they were called godparents, not name-parents (Paukštytè-Šaknienè 2002a: 168). The unification of the civil and religious acts that was practised during the Soviet period (the name-giving ceremony held at a so-called culture house or other official office $\longrightarrow$ baptism in church $\rightarrow$ a party at the parents' home) was not very long-lived. With the demise of the Soviet regime, the name-giving ritual disappeared. Theoretically, the ritual of name-giving is also possible in our days, yet it has never been practiced in recent decades. Baptism at church (in some cases chosen even by agnostics) prevails as a "family tradition"; it is practised by individuals seeking to act like Christians, and also by those who do not wish to stand out among the members of a local, professional or kindred community, or by those who just want an excuse for a celebration (PaukštytèŠaknienè 2002a: 167-169).

When independence was restored in Lithuania (1990), people no longer had to hide the fact of the sacrament of baptism. The more so, in the 1990s this sacrament started being given to adults, young and even senior people. It was a way of bringing the cycle of birth customs to a close, but not so much on the initiative of the parents but on the individual's own initiative. This phenomenon 
cannot be associated with the "ending" of the birth customs cycle in terms of the mother's social status. When baptizing young adults (often those who wanted to get married in church), the decision is mostly based on the will to become a member of the Christian community and to acquire the spiritual preparation to become parents.

Dzūkija is a Lithuanian ethnographic region where lankynos remained as a ritual up to the beginning of the twenty-first century. As baptisms were not held in the Soviet years, the lankynos marked the end of the birth customs cycle. In this case, according to Vyšniauskaite, who wrote about these customs in the $1960 \mathrm{~s}$, they were much more ceremonial:

Radynos (lankynos) would be celebrated in a very lively way in collective farm villages in Dzükija if a baptism was not held. In these cases, women and their husbands would participate, but usually they would arrive separately, the husbands coming later on after being invited by the father. (Vyšniauskaitè 1964: 468)

As the material from my field research shows, in the Soviet period, women from Dzūkija would bring their husbands along to the lankynos much more often, and as more visitors would gather, the feast would become larger. Becoming purely a social phenomenon, lankynos remained popular throughout the whole twentieth century. However, the changing cultural environment corrected not just the cycle of birth customs in the second half of the twentieth century but also the stages of the woman's return to regular life. Work on the collective farm, the changing duration of maternity leave periods, and the establishment of public nurseries changed the terms regulating a woman's return to the work collective. The lankynos element as an end to the cycle of birth customs, baptism, name-giving ceremonies, and presentation at church no longer correlated with the traditional end to the birth customs cycle.

Table 1. Diachronic changes of structural elements of the cycle of birth customs performed after the birth of a child

\begin{tabular}{|l|l|l|l|l|}
\hline \multicolumn{1}{|c|}{$\downarrow$} & $\begin{array}{l}\text { First } \\
\text { visiting of } \\
\text { the baby } \\
\text { and mother } \\
\text { (lankynos) }\end{array}$ & Baptism & $\begin{array}{l}\text { Ritual } \\
\text { cutting of } \\
\text { the hair }\end{array}$ & Churching \\
\hline $\begin{array}{l}\text { 1680-1699 } \\
\text { Lithuania Minor }\end{array}$ & widespread & widespread & known & widespread \\
\hline $\begin{array}{l}\text { 1900-1944 } \\
\text { SE Lithuania }\end{array}$ & widespread & widespread & not recorded & $\begin{array}{l}\text { common } \rightarrow \\
\text { disappearance } \\
\text { of the ritual }\end{array}$ \\
\hline
\end{tabular}




\begin{tabular}{|l|l|l|l|l|}
\hline $\begin{array}{l}\text { 1945-1989 } \\
\text { SE Lithuania }\end{array}$ & widespread & $\begin{array}{l}\text { common } \rightarrow \\
\text { forming an } \\
\text { alternative }\end{array}$ & not recorded & $\begin{array}{l}\text { only a few } \\
\text { cases } \\
\text { recorded }\end{array}$ \\
\hline $\begin{array}{l}\text { 1990-2007 } \\
\text { SE Lithuania }\end{array}$ & widespread & widespread & not recorded & not recorded \\
\hline
\end{tabular}

\section{BAPTISM AND LANKYNOS IN THE PERSPECTIVE OF HISTORY}

As we saw in the seventeenth-century accounts, the motivation behind baptism led to an early baptism in Lithuania Minor. Fast baptism was also recorded in Dzūkija in the late nineteenth century. Archival baptism documents from the Alytus church books of the Merkinè deanery for the years 1865, 1870, 1880, and 1890 show that infants were usually baptized the day after they were born (18 percent), less commonly two days (15 percent) or three days (15 percent) after they were born, or even on the day of their birth (8 percent) (Paukštytè 1999: 71).

Hurrying to baptize in Dzūkija in the late nineteenth-early twentieth centuries was caused not only by a high level of piety among the population, but also by the belief that the newborn needed special protection up to the point of baptism. According to this belief, the midwife had to constantly watch over the infant until it was baptized. A lantern would burn beside the baby at night to ward off witches who could kidnap the child or swap it for another; girls and young women would also sit by to watch over the baby. Not relying just on these measures, the midwife would also make the sign of the cross at windows, doors, on the ground and the ceiling. Windows and doors were marked with chalk blessed on the Feast of the Epiphany, the chimney and keyholes would be stuffed with sorb branches, and incense would be burned around the house each night (Krèvè-Mickevičius 1933: 37-38). In Western Europe, it was believed right up to the fourteenth century that a child who had died before being baptized would go to hell. Later, this belief changed to the child being stuck in limbo - an intermediate state between heaven and hell (Heywood 2001: 51). These beliefs were carried into the early twentieth century. According to people from Pavarènis (Varèna district), an unbaptized infant would not find peace until the Judgement Day. God would not allow infants to suffer, but they would have to wait on the threshold to heaven (Marcinkevičienè 1998: 134). The place where an unbaptized infant was buried was also important. Even up to 1940, unbaptized children would be buried separately from the other deceased, near those who had been hung or committed suicide. These graves were located separately in the corner of a cemetery or even outside the cemetery fence, on nonsacred land (Paukštytè 1999: 69-70). In critical cases, a dying infant could have 
been baptized by the midwife, and if the infant survived it would be baptized properly in church, yet the name given by the midwife would remain. During difficult births, before she knew the baby's gender, the midwife would give the child two names - one male and one female (Paukštytè-Šaknienè 2008: 469).

Even though baptism continued to be viewed as a Christian requirement in the second half of the twentieth and early twenty-first centuries, the time of baptism started to be postponed more and more. In the Merkinè area, in 1940-1965 christening on the 8th to 30th days after birth dominated, while in 1975-1999 baptisms done on the 31st to the 180th days prevailed (Paukštytè-Šaknienè 2002a: 154-156). In terms of Dzūkija in general, in 1974-1980 baptisms would be performed on children aged 0.87 months on average, in 1981-1990 - aged 3.79 months, in 1991-2000 - aged 4.67 months, and in 2001-2007, on children aged 5.84 months (Paukštytè-Šaknienè et al. 2009: 154-156). ${ }^{11}$

In the first half of the twentieth century, an infant would be visited when the mother had recovered some time after giving birth and before the baptism. When the baptism was performed after a longer interval, especially with the disappearance of midwives, people would wait until the mother felt strong enough to receive visitors. Thus, the time of the first visit was shifted by changes to the time of baptism and the trend to postpone the baptism for an increasingly longer time. Nonetheless, it was considered acceptable to visit the child before it was baptized. In the late twentieth-early twenty-first centuries, an opinion started to form that an infant could be visited after baptism, i.e., if the person wanting to see the baby had not visited the baby before it was baptized or had not been invited to the baptism ceremony or feast. According to a respondent born in 1967, sometimes babies would be visited up until they turned one year old, or people would express astonishment at the fact that "the child's already walking and some people are still visiting". Nonetheless, the survey of respondents showed that the lankynos usually lasted from one week up to 2-3 months. A certain order for visiting was followed up to the early twenty-first century: the first to visit would be the closest relatives and neighbours (1-2 weeks), then more distant relatives, co-workers, etc. In the case a child was not baptized or would be baptized already when they were older or had reached adulthood, the lankynos could be considered as the final structural element in the birth customs cycle.

Nevertheless, based on the experiences of the $d z \bar{u} k a i$, I can say that the lankynos and baptisms of the early twenty-first century still retained the traditional order of events, as there were only one-off cases where visiting would happen after the baptism. The timing of baptism in the first half of the twentieth century also depended on a stable period for being presented at church (from 3 to 9 , usually 6 weeks). As the custom of presenting the mother 
to church started to disappear, these terms started to be followed less rigidly. For example, a respondent born in 1928 (and married in 1948) stressed that a breastfeeding woman would not be taken into church and that she herself had only been taken into church a year after giving birth. Once this custom diminished in importance, the timing of the baptism rite was corrected in line with the traditional provision of not delaying an infant's baptism too long, and he or she was baptized according to the established customs for the particular period in the social environment. The personal decisions of women have also affected these customs. According to a female respondent from Kalesninkai (Šalčininkai district), born in 1951, it was best to baptize children while they were small, as up until then the parents would always "feel uneasy, so it paid not to drag out the process"; while being asked when a child should be baptized, some women responded that this depended on their health (Paukštytè-Šaknienè et al. 2009: 23).

According to this research, it may be concluded that the timing of baptism and the disappearance of the custom of being presented at church had a certain influence on birth cycle customs and their structure. On the other hand, all these structural chains in the cycle of birth customs are inseparable from social interaction factors.

\section{SOCIAL INTERACTION IN THE CUSTOMS OF BAPTISM AND LANKYNOS}

The rites that make up the cycle of birth customs mirror the social links that are active in a specific community. This is a space in which both magical and rational measures are harnessed by the family, local and religious communities to shield the mother and the child. In the late nineteenth-early twentieth centuries, a pregnant woman was held in high respect in daily life in Dzūkija. Members of the immediate and extended family as well as neighbours had to protect her from any discomfort and annoyances, yet on the other hand, in order to ensure a suitable appearance, character, physical and moral qualities and destiny for her child, the woman's social life was restricted (Krèvè-Mickevičius 1933: 30; Dunduliene 1999: 58-60). In these aspects, in the birthing period (and the first days after birth) the midwives truly stood out, and in the case of baptism, the role of the godparents was also important (Paukštytė 1995, 1999; Račiūnaitė 2002; Paukštytè-Šaknienè 2008). In the Soviet period and especially in the post-Soviet period, a woman's socio-cultural space underwent rapid changes. In the early twentieth century the range of her cultural contacts was considerably narrower (her home, village, the parish town, less frequently - journeys to visit relatives 
living in nearby parishes). In the Soviet years meanwhile, in the geographical sense, the circle of friends and relatives to be visited started to expand. The accelerated development of information and communication technology has had a significant influence on a person's way of thinking, behaviour, and perception of space in the twenty-first century (Floridi 2018). However, up until the twenty-first century, various superstitions that were related to determining the infant's future were still alive in Dzūkija (Paukštytè-Šaknienè 2002a: 143-172; Paukštytė-Šaknienè et al. 2009: 17-62). Being passed down from the grandparents' generation, they were often reinforced through personal experience and are thus recalled over the decades (Paukštytè-ŠSaknienè 2002a: 149); however, the place of giving birth has changed. Already in the Soviet period, home births with environmental and emotional links maintained in the village community via the midwife were replaced by the socially unfamiliar surroundings of medical institutions and interaction with professional medical personnel.

The changing social environment also altered the visiting tradition. In the early twentieth century, it was only women who participated in the lankynos (visiting), while from around the mid-twentieth century the husbands started to come as well. Modern visiting customs, according to the stories told by my research respondents, are often identified not just as "greeting a new person into the world", but also as a chance to catch up with friends who might live further away. A female respondent born in 1967 believed that lankynos was intended for a closer friendship among families. Also, it was a good opportunity to mend any arguments between neighbours. In this sense, lankynos maintained the traditional provision that anybody willing to come was welcome (unlike to a baptism). In the late nineteenth-second half of the twentieth centuries, almost the same people participated in lankynos and baptism, as most of the village community would be invited to the baptism, while in recent years (as respondents highlighted a number of times), the baptism feast would only be open to one's closest relatives and neighbours. Thus, the lankynos was left for those who wanted to visit the new family, for example friends, co-workers, and neighbours. A female respondent born in 1947 noticed certain diachronic changes to the lankynos custom. Even though now, as in her youth, the female neighbours would often visit the new baby together, they would come in smaller groups, only to visit a woman of a similar age with whom they shared a closer bond. Traditionally, the visitors would bring gifts (often for the baby) and would always be offered something to eat or drink. The respondents often said that only the closest relatives would be invited to baptisms, as they turned out to be expensive events. Also, it was said that they tried to organize the baptism rather soon after birth, as the treats offered to the constant visitors would also add up to a significant sum. Understandably, the quantity of visitors would 
depend on how many friends and relatives the parents had, and the closeness of their relationships. The difference was that during the lankynos, visitors would be offered what was on hand, while special meals would be organized for the baptism. However, it appears that these options were not that different in reality. The respondents replied that they had always planned ahead for the potential lankynos period and had thought about what they could serve their guests (especially during the Soviet years). Thus, I would say that the financial aspect of lankynos and the baptism feast is not as important in today's situation as the respondents claim it used to be. The difference is that there is a clearer trend where the baptism celebration is set aside for the closest relatives, while all the other community members who want to and feel obliged to visit the mother who has just had a baby choose to do so during lankynos. Perhaps the narrowing down of the circle of participants in the baptism ceremony was influenced by the fact of having to baptize in secret during the Soviet period, and the rejection of organizing a larger feast (so as not to draw the attention of neighbours). As a result, lankynos (a legal custom in all periods in history) remains as the most stable structural link in the social legitimization of a child within the cycle of birth customs. Parents could either organize the baptism and the post-ceremony feast or not, while anyone who wanted to honour the family would come under the pretext of lankynos.

Changes in social interaction when organizing a baptism are also evident in the choice of godparents. If in the late nineteenth-first half of the twentieth centuries it was usually reliable, religious people, relatives or neighbours (not prioritising either group specifically) who were chosen to be a child's godparents (Paukštytè 1999: 84; Paukštytè-Šaknienè et al. 2009: 23-24), in recent years in all the 24 locations I researched in Dzūkija, it was relatives chosen as godparents in 58 percent of localities, and friends as godparents chosen in 42 percent of locations. Meanwhile there were no results from any location where neighbours would be invited to act as godparents (Paukštytė-Šaknienė et al. 2009: 23-24).

When we look at the social interaction of baptism with the village community via the institution of midwives, there are also some fundamental changes that are visible. As the field research material shows, in the baptisms held in Dzūkija even today there is a symbolic "midwife" role; however, this duty is usually performed by an older woman from the family, most commonly the newborn's grandmother. In this case, for her services, i.e., preparing the infant ahead of baptism and handing it over to the godparents, she is given traditional gifts (as the midwife once was). A female respondent in the Varèna district, born in 1971, said that when her daughter was being baptized, her grandmother handed the dressed-up little girl to the godmother and received a shawl from her (Paukštytè-Šaknienè 2002a: 165). Towards the end of the baptism held 
in the Vilnius area, according to a woman born in 1969, a traditional "covering the infant" ritual was performed, asking to "buy roosters" from the guests participating in the baptism. In this way, money would be collected for the infant's grandmother (in earlier times, the midwife) (Paukštytè-Šakniene 2009 et al.: 31 ). The rite of bathing ${ }^{12}$ the infant's grandmother (or midwife, in earlier times) also still exists in Dzūkija. In earlier times, the midwife would be taken to be bathed "in order to ensure the infant's luck", yet this turned into a fun form of (symbolic) entertainment (Paukštytė-Šaknienè et al. 2009: 31-33). This is an evidence of modifying the baptism customs. In the late nineteenth-early twentieth centuries, the midwife was traditionally an important figure in the baptism rites, who sought to ensure the infant's protection until he or she acquired a new status, and she performed the role of a mediator between the family and the village community (Paukštytè 1999: 119-120). However, the experience of people from Dzūkija shows that the need to perform the midwife's role still remains, and this has been successfully adopted by a baptized infant's female relative. Thus, there is an obvious change in the dominant social interaction (moving from the village community to kinship networks). By looking at the customs involved in the birth cycle, we can see that even where some traditions have been preserved, the social meaning of these rites has changed. The goal to bring neighbourly relations closer in the late nineteenth-early twentieth centuries has been replaced in the late twentieth-twenty-first centuries with the need to intensify relationships between relatives of kin, enhancing blood relations with religion-based (spiritual kinship) links.

Table 2. Social interaction in birth cycle customs performed after the birth of a child

\begin{tabular}{|l|l|l|l|l|}
\hline \multicolumn{1}{|c|}{$\downarrow$} & $\begin{array}{l}\text { First } \\
\text { visiting of } \\
\text { the baby } \\
\text { and mother } \\
\text { (lankynos) }\end{array}$ & Baptism & $\begin{array}{l}\text { Ritual } \\
\text { cutting of } \\
\text { the hair }\end{array}$ & Churching \\
\hline $\begin{array}{l}\text { 1680-1699 } \\
\text { Lithuania } \\
\text { Minor }\end{array}$ & $\begin{array}{l}\text { local } \\
\text { community, } \\
\text { community of } \\
\text { relatives } \\
\text { (women) }\end{array}$ & $\begin{array}{l}\text { local } \\
\text { community, } \\
\text { community of } \\
\text { relatives, } \\
\text { confessional } \\
\text { community }\end{array}$ & $\begin{array}{l}\text { local } \\
\text { community, } \\
\text { community } \\
\text { of relatives } \\
\text { (women or } \\
\text { men) }\end{array}$ & $\begin{array}{l}\text { confessional } \\
\text { community, } \\
\text { local } \\
\text { community, } \\
\text { community of } \\
\text { relatives }\end{array}$ \\
\hline $\begin{array}{l}\text { 1890-1944 } \\
\text { SE Lithuania }\end{array}$ & $\begin{array}{l}\text { local } \\
\text { community, } \\
\text { community } \\
\text { of relatives } \\
\text { (women) }\end{array}$ & $\begin{array}{l}\text { local } \\
\text { community, } \\
\text { community of } \\
\text { relatives, } \\
\text { confessional } \\
\text { community }\end{array}$ & not recorded & $\begin{array}{l}\text { confessional } \\
\text { community, } \\
\text { local } \\
\text { community } \rightarrow \\
\text { disappearance } \\
\text { of the ritual }\end{array}$ \\
\hline
\end{tabular}




\begin{tabular}{|l|l|l|l|l|}
\hline $\begin{array}{l}\text { 1945-1989 } \\
\text { SE Lithuania }\end{array}$ & $\begin{array}{l}\text { local } \\
\text { community, } \\
\text { community of } \\
\text { relatives } \\
\text { (women and } \\
\text { men) }\end{array}$ & $\begin{array}{l}\text { local } \\
\text { community, } \\
\text { community of } \\
\text { relatives, } \\
\text { partly } \\
\text { confessional } \\
\text { community }\end{array}$ & not recorded & $\begin{array}{l}\text { only a few } \\
\text { cases recorded }\end{array}$ \\
\hline $\begin{array}{l}\text { 1990-2007 } \\
\text { SE Lithuania }\end{array}$ & $\begin{array}{l}\text { local } \\
\text { community, } \\
\text { community } \\
\text { of relatives } \\
\text { (women and } \\
\text { men) }\end{array}$ & $\begin{array}{l}\text { community } \\
\text { local } \\
\text { communitives, } \\
\text { confessional } \\
\text { community }\end{array}$ & not recorded & not recorded \\
\hline
\end{tabular}

\section{CONCLUSIONS}

The rituals of social legitimization of the birth of a child, analysed in the article, are an integral part of the system of birth customs covering the period from conception to the woman's introduction to the church after childbirth. By analysing sources testifying to the cycle of birth customs in Lithuania Minor in the seventeenth century, we find numerous analogies with the customs, their structure and social aspects in south-eastern Lithuania (the Dzūkija ethnographic region) of the late nineteenth-early twenty-first centuries. On the other hand, the changes to rite terminology over time (the same terms refer to different episodes) show a possible dynamic to the structure of birth custom cycles. Both in the seventeenth-century Lithuania Minor and in south-eastern Lithuania of the late nineteenth-early twenty-first centuries, we can distinguish a part of the childbirth custom system performed after the birth of a child: 1) lankynos (rodynos, radynos), 2) baptism, and 3) "churching" (being presented at church - only until the middle of the twentieth century). All of these stages were related to a woman's obligation to her future child, family, village or religious community, along with the protection and control of the afore-mentioned social institutions.

Each structural stage in the birth customs process signified both autonomous and general functions: becoming ready to perform the role of a mother, socially legitimizing the birth of a new person, and the woman's return to her usual social situation. As Grimes mentioned, ritual, like art, is the child of imagination, but the ritual imagination requires an invention, a constantly renewed structure, on the basis of which a bodily and communal enactment is possible (Grimes 2000: 4). The specific features of the birth customs cycle allow us to 
at least partially compensate for the disappearing structural links in this cycle. With the disappearance of the "churching" or presentation at church, some of the symbolic meanings of reintroducing a woman into her regular social situation have been taken over by baptism. By restricting the possibility of baptizing an infant and rejecting the civil name-giving ceremony as an alternative, we could say that the most stable link in the cycle - lankynos - has taken over the function of presentation back into regular social life. On the other hand, with the disappearance of the local community and with separate members making their own individual decisions more often, a late baptism (sometimes combining several children born in close succession) denies the meaning of this element in the birth customs cycle. The changing cultural surrounds of the second half of the twentieth century have modified the forms of these obligations, reducing the power of customs passed down from one generation to the next. Baptisms in the late nineteenth-first half of the twentieth centuries were dominated by representatives of the local community, who were replaced by family relatives, or people of kin, in the second half of the twentieth-early twenty-first centuries. Now it is usually relatives who are invited to baptisms, while the role of a female representative from the local community - the midwife - is usually performed by an older woman from the infant's family, usually a grandmother. On the other hand, when analysing the lankynos custom, we notice a reduction in the significance of the female community, its precedent being the late seventeenthcentury customs of lankynos and the ritual cutting of the infant's hair.

Our rapidly modernizing society has preserved only separate elements of tradition in our days, leading to a narrower scope of the birth customs cycle, the local community and female ritual space. Thus, the research has revealed the expression of only single elements of traditional culture in the diachronic perspective. However, in conjunction with the changing cultural environment even these elements, often retaining their early form, are expressed with a different meaning, denoting the birth of a new person through ritualized practices.

\section{NOTES}

1 In traditional culture, the fact of name giving is also very significant. A baby without a name is not a complete human being. Folk religiosity occasionally underlines the even bigger importance of the very name than that of christening. The death of an unbaptized unnamed baby was considered a sin, and the funeral was very different from the 'normal' ones (see also Sedakova 2020).

2 A civil birth registry was introduced in the Klaipedda District only in 1876, and in the rest of Lithuania in 1940. During the period under Nazi occupation (1941-1944/1945) 
it was abolished, before being reintroduced when Lithuania was occupied again by the Soviet Union.

3 In recent years, the increasingly popular Romuva Ancient Baltic Rite Society has been disclaiming Christian baptism and seeking to revive the pre-Christian name-giving/ baptism rite, during which one becomes a member of a family rather than a religious community (Trinkūnas 2000: 28-31; Romuva n.d.). Thus, the mid-twentieth century goal to abolish Christian rituals is being replaced by the desire of certain members of the society to revive pagan birth rituals in the early twenty-first century. Pre-Christian name-giving/baptism ceremonies in Dzūkija were not mentioned by respondents during the field research.

4 Lithuanians lived in a part of Prussia which from 1525 was called Lithuania Minor, or Prussian Lithuania. From the sixteenth century, the Evangelical Lutheran faith predominated on this territory, with Catholicism being the main faith in the rest of Lithuania. In 1923-1939 and after 1945, some of this territory belonged to Lithuania, while after 1945 the remainder of Lithuania Minor was annexed to Russia and came to be known as the Kaliningrad oblast (region). In 1940-1941 and 1945-1990 Lithuania was under Soviet occupation and was known as the Lithuanian Soviet Socialist Republic.

5 The term rodynos in historical sources is also referred to as radynos, but describes the same ritual. The word rodynos can be associated with the words in the Slavic languages: Belarusian радзіны, Russian родины. However, these concepts can be associated with the Lithuanian words "show" (rodyti) or "find" (rasti) a baby. In the twentieth century the term lankynos (visiting) was more commonly used.

6 Christian churches adhered to the Jewish tradition according to which a woman could not be in sacred places during 40 days after giving birth (Heywood 2001: 52-53).

7 Žemyna (from Lithuanian: žeme - earth) is the goddess of the earth in Lithuanian religion.

8 Laima (Laimè) is a Lithuanian and Latvian female mythical creature. In fairy tales and ethnographic sources, Laima is most often the creator of destiny, the goddess of destiny, and also the guardian of pregnant women.

9 For a review of the first hair-cutting tradition in different countries see also Hulubaş 2020.

${ }^{10}$ According to Irina Sedakova, one of the specific characteristics of traditional life cycle celebrations in Bulgaria was the frequent motif expressed in a particular lexis, and the belief that magical actions and rituals repeated twice could bring negative outcomes (Sedakova 2007: 253-273). In Lithuanian culture in the seventeenth century, a repeated baptism was perceived as a positive act.

${ }^{11}$ Based on families who baptized their children before they turned two years old.

12 Relatives or guests put the midwife or grandmother on a wheelbarrow or a cart and drove her to the nearest water body (river or pond) and then threw her into the water. 


\section{REFERENCES}

Balys, Jonas 1979. Vaikystè ir vedybos. [Childhood and Marriage.] Silver Spring: Lietuvių tautosakos leidykla.

Balys, Jonas 2004. Raštai. T. 5: Vaikystè. Vedybos. Mirtis ir laidotuvès. [Writings. Vol. 5: Childhood. Marriage. Death and Funerals.] Vilnius: Lietuvių literatūros ir tautosakos institutas.

Cressy, David 1999 [1997]. Birth, Marriage \& Death: Ritual, Religion, and the Life-Cycle in Tudor and Stuart England. Oxford: Oxford University Press. DOI:10.1093/acprof:oso/9780198201687.001.0001.

Davies, Douglas 1994. Christianity. In: Jean Holm \& John Bowker (eds.) Rites of Passage. London \& New York: Pinter Publishers, pp. 41-65.

Dundulienè, Pranè 1999. Senieji lietuviu šeimos papročiai. [Old Lithuanian Family Traditions.] Vilnius: Mokslo ir enciklopedijų leidybos institutas.

Filimonova, Tamara 1999 [1997]. Nemtsy. [Germans.] In: Natal'ia Gratsianskaia \& Aleksandr Kozhanovskii (eds.) Rozhdenie rebenka $v$ obychaiakh i obriadakh: strany zarubezhnoi Evropy. Moscow: Nauka, pp. 164-184.

Floridi, Luciano 2018. Ketvirtoji revoliucija: Kaip infosfera keičia mūsu tikrovę. [The Fourth Revolution: How the Infosphere Is Reshaping Human Reality.] Vilnius: Eugrimas. Available at http://www.lma.lt/uploads/files/KNYGOS/Ketvirtoji_ revoliucija_.pdf, last accessed on 22 October 2020.

Gantskaia, Ol'ga 1999. Poliaki. [Poles.] In: Natal'ia Gratsianskaia \& Aleksandr Kozhanovskii (eds.) Rozhdenie rebenka $v$ obychaiakh $i$ obriadakh: strany zarubezhnoi Evropy. Moscow: Nauka, pp. 7-22.

Gennep, Arnold van 1960 [1909]. The Rites of Passage. London: Routledge and Kegan Paul.

Gratsianskaia, Natal'ia \& Kozhanovskii, Aleksandr 1999 [1997]. Zakliuchenie. [Conclusion.] In: Natal'ia Gratsianskaia \& Aleksandr Kozhanovskii (eds.) Rozhdenie rebenka v obychaiakh i obriadakh: strany zarubezhnoi Evropy. Moscow: Nauka, pp. 510-515.

Grimes, Ronald L. 2000. Deeply into the Bone: Re-Inventing Rites of Passage. Berkeley \& Los Angeles \& London: University of California Press.

Grimes, Ronald L. 2013. The Craft of Ritual Studies. Oxford: Oxford University Press. DOI:10.1093/acprof:oso/9780195301427.001.0001.

Heywood, Colin 2001. A History of Childhood: Children and Childhood in the West from Medieval to Modern Times. Cambridge: Polity Press.

Hulubaş, Adina 2020. Taking Hold of the Future: Active Childbirth Practices and Beliefs in Romania (in the Home Country and in Migration). Folklore: Electronic Journal of Folklore, Vol. 80, pp. 191-214. https://doi.org/10.7592/FEJF2020.80.hulubas.

Krèvè-Mickevičius, Vincas 1933. Krikštynų apeigos Dzūkijoje. [Baptism Rituals in Dzūkija.] Mūsu tautosaka, Vol. 7, pp. 30-46.

Lardellier, Pascal 2019. The Ritual Institution of Society. Vol. 2. London: John Wiley \& Sons. DOI:10.1002/9781119508786.

Lepneris, Teodoras 2011. Prūsu lietuvis / Der Preusche Littau. Edited by Vilija Gerulaitienè. Vilnius: LII leidykla. 
Lepner, Theodor 1744. Der Preusche Littauer. Danzig: Johann Heinrich Rüdiger.

Marcinkevičienė, Nijolè 1998. Pavarènis. [Pavarènis Village.] Vilnius: Lietuvos liaudies kultūros centras.

Paukštytė, Rasa 1995. Gimtuvės. [Birth Customs.] In: Angelė Vyšniauskaitė \& Petras Kalnius \& Rasa Paukštytè. Lietuviu šeima ir papročiai. [Lithuanian Family and Traditions.] Vilnius: Mintis, pp. 396-441.

Paukštytė, Rasa 1999. Gimtuves ir krikštynos Lietuvos kaimo gyvenime XIX a. pabaigoje$X X$ a. pirmojoje puseje. [Birth and Baptism in Lithuanian Village Life: End of the 19th - 1st Half of the 20th Centuries.] Vilnius: Diemedis.

Paukštytė-Šaknienè, Rasa 2002a. Merkiniškių gimtuvės ir krikštynos: Tradicinių kultūros elementų sklaida XX amžiuje. [Birth and Baptism among Merkinė Inhabitants: Diffusion of Cultural Elements in the 20th Century.] Lietuviu kataliku mokslo akademijos metraštis, Vol. 21, pp. 143-172. Available at https://www.lkma.lt/ site/archive/metrastis/XXI/lkma-metrastis_t21_p143-172_Paukstyte-Sakniene. pdf, last accessed on 22 October 2020.

Paukštytė-Šaknienè, Rasa 2002b. Lokalinès kultūros struktūrinès kaitos kontūrai: Gimtuvių papročiu ciklas XX a. Dzūkijoje. [Contours of the Structural Change in Local Culture: The Cycle of Birth Customs in the 20th-Century Dzūkija.] Lietuvos etnologija. Socialinés antropologijos ir etnologijos studijos, Vol. 2, No. 11, pp. 71-88. Available at http://etalpykla.lituanistikadb.lt/fedora/objects/LT-LDB0001:J.04 2002 1367158123252/datastreams/DS.002.0.01.ARTIC/content, last accessed on 22 October 2020.

Paukštytė-Šaknienè Rasa 2007. Ritual, Power and Historical Perspective: Baptism and Name-giving in Lithuania and Latvia. Journal of Ethnology and Folkloristics, Vol. 1, No. 1-2, pp. 115-129. Available at https://www.jef.ee/index.php/journal/ issue/view/6, last accessed on 22 October 2020.

Paukštytė-Šaknienè, Rasa 2008. Gimtuvès. [Birth Customs.] In: Angelè Vyšniauskaitè \& Petras Kalnius \& Rasa Paukštytè-Šaknienè. Lietuviu šeima ir papročiai. [Lithuanian Family and Traditions.] Vilnius: Mintis, pp. 434-482.

Paukštytè-Šaknienè, Rasa 2009. Mažosios Lietuvos kultūrinio savitumo raiška senưjų rašytinių šaltinių kontekste. [Expression of Cultural Distinction of Lithuania Minor in the Context of Old Written Sources.] Lituanistica, Vol. 55, No. 3-4 (79-80), pp. 162-173. Available at http://mokslozurnalai.lmaleidykla.lt/publ/0235716X/2009/3-4/162-173.pdf, last accessed on 22 October 2020.

Paukštytė-Šaknienè 2011 = Paukshtite-Shaknene, Rasa. Malaia Litva i khristianskaia kul'tura: motivatsiia kreshcheniia detei. [Lithuania Minor and Christian Culture: Motivation for Child Baptism.] In: Grasilda Blazhene \& Nataliia Likhina (comps.) Kul'turnoe nasledie Vostochnoi Prussii: sbornik statei. Vol. 2. Kaliningrad: Izd-vo BFU im. I. Kanta, pp. 9-15.

Paukštytė-Šaknienè, Rasa 2014. Viara, ritual i religiozna kharmoniia. [Harmony of Faith, Ritual and Religiosity.] Bulgarski folklor, Vol. 1, pp. 56-67. Available at https:// www.ceeol.com/search/article-detail?id=126718, last accessed on 26 October 2020.

Paukštytè-Šaknienè, Rasa \& Savoniakaitè, Vida \& Šaknys, Žilvytis \& Šidiškienè, Irma 2009. Lietuvos kultūra: Dzūkijos ir Suvalkijos papročiai. [Lithuanian Culture: Traditions in Dzūkija and Suvalkija.] Vilnius: Lietuvos istorijos instituto leidykla. 
Pretorijus, Matas 2006. Prūsijos įdomybès arba Prūsijos regykla. [Prussian Attractions or Prussian Sight.] Vol. 3. Vilnius: LII leidykla.

Račiūnaitè, Rasa 2002. Moteris tradicineje lietuviu kultūroje: Gyvenimo ciklo papročiai (XIX a. pabaiga - XX a. vidurys). [Lithuanian Village Woman in Traditional Culture: The Customs of Life Cycle at the End of the 19th and First Half of the 20th Centuries.] Kaunas: Vytauto Didžiojo universitetas.

Rao, Ursula 2006. Ritual in Society. In: Jens Kreinath \& Joannes Augustinus Maria Snoek \& Michael Stausberg (eds.) Theorizing Rituals. Vol. 1: Issues, Topics, Approaches, Concepts. Leiden \& Boston: Brill, pp. 143-160. https://doi. org/10.1163/9789047410775_008.

Romuva n.d. = Romuva: Senoves baltu religinè bendrija . [Romuva: Ancient Baltic Rite Society.] Available at https://romuva.lt/apeigos/palaiminimas-vardynos/, last accessed on 22 October 2020.

Roth, Juliana \& Roth, Klaus 1990. The System of Socialist Holidays and Rituals in Bulgaria. Ethnologia Europaea, Vol. 1, No. 20, pp. 107-120. https://doi. org/10.16995/ee.1322.

Sedakova, Irina 2007. Balkanskie motivy v iazyke i kul'ture bolgar. Rodinnyi tekst. [Balkan Motifs in Bulgarian Language and Culture: Birthlore.] Moscow: Indrik. Available at https://inslav.ru/publication/sedakova-i-balkanskie-motivy-v-yazykei-kulture-bolgar-rodinnyy-tekst-m-2007, last accessed on 26 October 2020.

Sedakova, Irina 2020. Unlived Life: The Death and Funeral of a Child in Slavic Traditional Culture. Folklore: Electronic Journal of Folklore, Vol. 80, pp. 47-68. https:// doi.org/10.7592/FEJF2020.80.sedakova.

Trinkūnas, Jonas 2000. Baltu tikejjimas: Lietuviu pasaulejauta, papročiai, apeigos, ženklai. [The Faith of the Balts: Lithuanian Worldview, Customs, Rites, Signs.] Vilnius: Diemedis.

Vèlius, Norbertas (ed.) 1996. Baltu religijos ir mitologijos šaltiniai. [Sources of Baltic Religion and Mythology.] Vol. 1. Vilnius: Mokslo ir enciklopedijų leidykla. Available at http://www.sarmatija.lt/images/stories/Baltu\%20religija.pdf, last accessed on 26 October 2020.

Vèlius, Norbertas (ed.) 2003. Baltų religijos ir mitologijos šaltiniai. [Sources of Baltic Religion and Mythology.] Vol. 3. Vilnius: Mokslo ir enciklopedijų leidybos centras.

Vyšniauskaitè, Angelè 1964. Šeimos buitis ir papročiai. [Family Life and Traditions.] In: Angelè Vyšniauskaitè (ed.) Lietuvių etnografijos bruožai. Vilnius: Valstybinė politinès ir mokslinès literatūros leidykla, pp. 448-526.

Vyšniauskaitè, Angelè 1967. Lietuviu šeimos tradicijos. [Lithuanian Family Traditions.] Vilnius: Mintis.

Zelenin, Dmitrii 1991. Vostochnoslavianskaia etnografiia. [Ethnography of East Slavs.] Moscow: Nauka.

Rasa Paukštytè-Šaknienè is Senior Research Fellow $(\mathrm{PhD})$ at the Department of Ethnology and Anthropology, Lithuanian Institute of History, Vilnius, Lithuania. Her research interests are in the field of traditional and modern culture - family, family traditions, ritual, neighbourhood, ethnic minorities, ethnology of city, and history of ethnology.

rasa.sakniene@gmail.com 


\title{
THE STRUCTURE AND GENESIS OF ONE TYPE OF MAGIC SPELL AGAINST CHILDREN'S INSOMNIA AMONG SLAVIC PEOPLES
}

\author{
Tatiana Agapkina \\ Leading Research Fellow, Sc.D. \\ Institute for Slavic Studies \\ Russian Academy of Sciences, Russia \\ agapi-t@yandex.ru
}

\author{
Andrei Toporkov \\ Leading Research Fellow, Sc.D. \\ Corresponding Member of the Russian Academy of Sciences \\ Gorky Institute of World Literature, Russia \\ atoporkov@mail.ru
}

\begin{abstract}
Among Slavic charms for children who suffer from insomnia, there are texts depicting mothers going out of their houses, carrying their babies while looking at the forest or a single tree and reciting a magic spell addressed to a mythological character, asking for the creature's help in taking away the baby's cries and restoring the baby's sleep. One variation of such texts originates from a manuscript called Summa de confessionis discretione. This text was compiled in Latin by a monk named Rudolf, evidently in the middle of the thirteenth or the beginning of the fourteenth century. The fact that the magic spells for insomnia in children seem to have existed already in the thirteenth or fourteenth century, and that in the nineteenth and twentieth centuries they were widely spread on the broad territory where Eastern, Southern, and Western Slavs lived, testifies to the ancient origins of this type of magic spell.
\end{abstract}

Keywords: Forest Mother, insomnia, monk Rudolf, Slavic charms, Summa de confessionis discretione, Upper Silesia

\section{INTRODUCTION}

Magical charms for children who suffer from insomnia and night crying are widely known among various Slavic peoples. Of special interest are texts where a mother of a child suffering from insomnia goes out of the house carrying the baby, looks at the forest or a single tree and recites a magic spell addressed 
to a mythological character (for example, the forest woman - lesnaya baba) or a natural object (such as a forest, an oak), asking for the creature's help in taking away the baby's cries and restoring the baby's sleep (Budziszewska 1982; Vinogradova 1988; 2016: 269-278; Agapkina \& Toporkov 1990; Agapkina 2010: 264-269; 2019).

Similar texts were recorded numerous times in the nineteenth-twentieth centuries among Eastern Slavs (mostly among Ukrainians and Belarusians) as well as among Southern Slavs (Serbs and Bulgarians); among Western Slavs (Poles and Czechs) only single instances are known. Outside the Slavic world, these texts were also recorded among Romanians. The quantitative ratio between discovered texts is as follows: Ukrainian texts - 49, Belorussian - 45, Russian - 6, Serbian - 5, Bulgarian - 5, Czech - 1, Polish - 1, Romanian - 2.

\section{THE STRUCTURE OF MAGIC SPELLS FOR INSOMNIA IN CHILDREN}

For this type of magic spell, the following structural elements are common:

1. As a rule, these magic spells are addressed to mythological creatures (the forest woman - lesnaya baba, the old forest couple - lesnye baba $i$ ded) or to natural objects such as the forest itself, an oak, etc. The forest and the trees themselves (oaks and birches) are personified and often perceived as mythological creatures. These magic spells can be addressed to a sunset or to specific heavenly bodies.

2 . The spell's characters include a mother and her child and a female mythological creature and her child. In this case, the human mother and her child are taken as real, while the mythological creature and her child belong to an imaginary world. Many texts specifically mention that the human baby and the baby of the mythological creature are of opposite genders. Thus, if the human woman has a boy, then the mythological creature's child is a girl and vice versa. Some magic spells express a wish that these children marry, or that one child misses the other.

A number of publications contain two variations of the same text which vary in structure depending on the gender of the suffering child. Below we demonstrate an appeal to the trees from a Ukrainian magic spell:

(Коли хлопеиь): Дубе, дубе зеленьй! Маєшь дочки, березки. ... (Коли девчина): Березе, березе зеленая! Маєшь дубки, сынки... (Balagur 1847: 267-268). 
(If it is a boy) Oak, green oak! Your daughters are birch-trees. ... (If it is a girl): Birch-tree, green birch-tree! Your sons are oaks...

3. If we consider the dynamics of a magic spell, we should denote two situations - its beginning and its end, and we can identify the exchange of human and mythological babies' states, crying for silence. At the beginning of a magic spell, a woman's child is crying while the child of a mythological creature is sleeping quietly. After this, a wish is stated that the woman's child would, in turn, sleep quietly, while the child of the mythological creature would cry.

4. The desired situation should be the result of concrete actions taken by the subject performing a magic spell. On the one hand, a woman offers to form friendly relationships and even kinship between herself and the mythological creature. On the other hand, she asks the mythological creature to take away her baby's night crying and return it to sleep and peace. In Ukrainian and Belorussian magic spells, the offers to establish kinship are often expressed by the words 'posvataiemsya, pobrataiemsya', which may be translated as 'let's become relatives by marrying our children', and 'we will be sisters- and brothers-in-law'.

Thus, the process of healing a baby's insomnia is described in magic spells as a specific exchange of crying and sleep - crying for sleep and sleep for crying. Both are presented as material objects. In so doing, the idea of exchange and the idea of establishing kinship are reconciled with each other, because in folk culture recognition of symbolical kinship or fraternizing, as a rule, are accompanied by bodily contact (handshakes, kisses) and the exchange of personal items. We propose that in this case sleep and night crying serve as symbolical values, exchanges of which result in the formation of an artificial kinship between a human and a mythological creature.

5. In various Slavic traditions, the desires expressed by a subject of a magic spell are slightly different, but they can generally be summed up to three basic variants:

5.1. A woman informs a female mythological creature that she has a son, and the creature has a daughter (or vice versa), and offers to take away night crying of her baby. Here is an example from the Ukrainian magic spell:

Lis-lisowyna, pobratajemosia, poswatajemosia, u tebe doczka, a u mene syn; woźmy sobi s mojoho syna $i$ uroki-uroczyszcza... (Talko-Hryncewicz 1893: 214-215, № 24)

Forest, forest, let's be sworn brothers, let's be match-makers, you have a daughter, and I have a son; take bad luck from my son... 
5.2. A woman informs a mythological creature that she has a son, and a creature has a daughter (or vice versa), and offers to marry them. Here is an example from the Belorussian magic spell:

Zara-zaryca, Bożaja pamacznica, jość u Ciabie synok Wasilok (księżyc), a u mianie daczuszka (Hanulka), budziem ich żanić umieście! Jość u (Hanulki) babka-Bożaja matka, waźmi Ty jaje krywatù, tamatù i kryksy i płaksy rannyja i poznyja, paudnyja i dziannyja i daj jej son! (Wereńko 1896: 207, № 16)

Dawn-dawn, God's helper, you have a son, Vasilyok (the moon), and I have a daughter (Ganul'ka), we will marry them! (Ganul'ka) has a granny who is God's mother, take her crookedness, throbbing and crying early in the morning and late in the evening, during afternoon and during the day, and give her sleep!

5.3. A woman informs a mythological creature that up until then her baby has been crying about the baby of a mythological creature, and says that in the future the baby of the mythological creature will be crying about her baby. Consider a Serbian magic spell:

О, шумина мати, до сад плака моје дете за твојил дететол, а од сад нека плаче твоје дете из-за мојил! (Grbich 1909: 124)

Oh, forest mother, until now my baby has been crying about your baby, and from now on let your baby cry about my baby!

\section{MAGICAL TEXT FROM SUMMA DE CONFESSIONIS DISCRETIONE}

This group of magic spells has attracted special attention because one of the variants of these texts occurs in a manuscript called Summa de confessionis discretione, compiled in Latin by a monk called Rudolf, evidently in the middle of the thirteenth or the beginning of the fourteenth century. The handbook was stored in the Cistercian monastery of Rudy in Upper Silesia (near the modern Polish city of Katowice), and was later given to the university library in Wroclaw, where it is preserved now.

Included in the manuscript is an array of guides for confessors in their confessional practice - and it is known in academic literature as The Catalog of Magic by the Cistercian monk Rudolf. Three chapters of these penitentials (chapters VIII, IX, and X) are devoted to the rites and beliefs of local people. The manuscript describes, in detail, magic actions performed on behalf of children 
(chapter VIII), magic actions carried out by virgins and married women (chapter IX), and magic actions aiming to achieve happiness (chapter X). The materials in each section are presented systematically, accompanied by detailed descriptions of ritual actions and separate magic formulas. All of these observations suggest that the compiler had witnessed at least some of the described ethnographical facts.

For the first time, The Catalog of Magic was published by Joseph Klapper in 1915, parallel with a German translation (Klapper 1915). In 1955 Edward Karwot published The Catalog of Magic in Polish along with extensive research (Karwot 1955). Karwot calculated that the manuscript was compiled in Upper Silesia between 1235 and 1250, while not denying the possibility that Rudolf had collected some of the materials earlier in Małopolska, since the Rudy Cistercian monastery had been founded around 1255 by Prince Vladislav I of Opole, who relocated monks from Jędrzejów monastery in Małopolska.

Later on investigation of The Catalog of Magic developed along two basic directions of analysis. On the one hand, scholars analyzed the manuscript itself, which included Summa de confessionis discretione, the place of the manuscript in the Rudy Cistercian library, and the place of The Catalog of Magic in the religious and cultural context of the thirteenth-fourteenth centuries. On the other hand, scholars investigated folklore beliefs and magical practices, which were described by Rudolf, comparing them to similar beliefs and practices among Poles, Germans, and other Slavic and Germanic peoples (Barnat 2000; Bracha 2000; Smoczyńska-Reiner 2007).

While researching The Catalog of Magic, scholars have made many valuable observations, but there is no general agreement on the ethnicity of people practicing the rites described in the manuscript. If Karwot believed that Rudolf documented the customs of Slavic peoples from Upper Silesia or Małopolska, then Klapper and a group of researchers from the end of the twentieth century until the beginning of the twenty-first century thought that Rudolf described German beliefs. There remains an array of questions as to when and where Summa de confessionis discretione was compiled as well as what Brother Rudolf's ethnicity might have been.

We do not propose to settle the question of the origins of The Catalog of Magic but present a more modest project. The subject of our attention is a section in The Catalog of Magic devoted to the magic practice of calming babies who did not sleep at night and whose crying bothered those around them:

Retro ostium stantes vespere puerum in sinu gestantes vocant mulierem silvestrem, quod faunam dicimus ut puer fauni ploret, suus taceat (Karwot 1955: 23). 
In the evening, carrying a baby, someone goes out of doors and calls a forest woman, who we call Fauna, to make Fauna's baby cry, and their baby silent.

As far as we know, similar German magic spells have never been recorded, yet at the same time there are more than 100 similar texts documented among Slavic peoples, collected from the spread territory where Eastern, Southern, and Western Slavs lived.

The fact that the text was written down in Latin makes studying it more complicated, especially when there is no certainty about the original language (Slavic or German) in which it was recited. What is important is that Slavic tradition includes texts which provide parallels to the text from The Catalog of Magic not only in terms of separate words and phrases but also in terms of rites and related pagan beliefs. The parameters for comparison include the pragmatics of the ritual and its location, the mythological 'forest woman' and, finally, the tactics of human behavior towards otherworldly spirits.

\section{THE CHARM AGAINST CHILDREN'S INSOMNIA IN SLAVIC TRADITION}

Despite the fact that the text in Latin is concise, it does make it possible to judge which magical practices were used by Rudolf's informants to return a disturbed child to healthy sleep, and which magical formulas were recited during the ritual.

1. Although Rudolf's record does not say who performed this ritual, it is fairly obvious that it was a mother of a child or a female healer. We can say with a great deal of confidence that the ritual was performed by a woman and not by a man, because among Slavic and Germanic people the whole sphere of magic healing related to small children was controlled exclusively by women.

2. It is obvious that the ritual was performed over a baby because, according to Rudolf's description, the baby was held in somebody's hands. The woman was supposed to leave the house to perform this ritual. However, Rudolf did not say how far the woman went away from the house; by analogy with Slavic rituals recorded in the nineteenth-twentieth centuries we may guess that she performed a magic spell standing near the door of her house while looking at the forest or at a single tree somewhere nearby. Here is an example of a parallel description of a similar ritual recorded in Podol'ye (Ukraine) in 1867: 
For insomnia: in the morning before dawn stand at the place where trash from the house is thrown, look at the forest, first say the Lord's prayer, and then say the following:

"Добри вічір тобі ліси недобори; посватайлося и побратайлося, ти маешь сына, а я маю дочку ... на тобі плаксавицю, дай міні соновищю, нихай ні спит, ні дрілае, нихай по лісі гуляе, алоя хрещена порожена нихай спит як день, так нічь."

Good evening to you, forest, let's do match-making and be in-laws; you have a son, and I have a daughter ... take the crier, give me a sleeper, let [your baby] not sleep, not nap, let [your baby] walk in the forest, and my baptized [daughter], born by me, let her sleep day and night.

... You should certainly look at the forest; otherwise, according to the healer's words, you will take away sleep from the one whose house you are looking at. (M.B. 1867: 694)

Thus, the special structure of this ritual described in the nineteenth-twentieth centuries implies a relationship of two locations - a human habitation and forest, establishing contact between them via a human glance. Since Rudolf's record is rather brief, we cannot be certain about the place of the ceremony he described, but it is likely that the ritual referred to in the manuscript was not much different from the ones we found in the nineteenth- and twentiethcentury materials.

3. According to Brother Rudolf, the magic spell was addressed to 'the forest woman who we call Fauna'. Obviously, the bearers of tradition called this character the forest woman, and the expression 'which we call Fauna' is Rudolf's glossary. The fragment focusing on a 'forest woman who we call Fauna' is somewhere in between the ritual description (which is at the beginning of the record) and magic formula 'to make Fauna's baby cry, and their baby would become silent,' which completes the record.

In the similar Slavic and Romanian magic spells, recorded in the nineteenth and twentieth centuries, there are also words addressed to the forest woman or the forest mother, for example: Belorussian баба барава, лесавая баба, лисавая баба Марына, лесовые дзедь и бабы; Bulgarian баба Гора, горска майка; Serbian горска мајка, горска вештица, шулина мати; Romanian muma pădurii [mother of the forest]. In The Catalog of Magic and in the magic spells recorded in the nineteenth and twentieth centuries the forest woman is somehow connected with children's insomnia, because people addressed their words especially to her to help a child stop crying during the night. 
4. According to Rudolf's text, the forest woman also had her own child. The system of characters is based on the symmetry between a mythological forest world and the real human world, and includes at least four characters: the forest woman, the child of the forest woman, the human woman, and the child of the human woman. The ritual has a form of a dialogue between the woman and the mythological creature, the first using a magic formula; in response she expects help in healing her baby. It is interesting that she expects the forest creature to help solve her family problems; i.e., the forest world has a quite positive value. It may also be noted that Brother Rudolf does not blame the ritual performer worshiping evil spirits and does not condemn her; he documents the ritual in a neutral and objective way, the same way as a modern ethnographer would document this fact.

5. The text completes with the words 'let Fauna's baby cry, and my baby be silent', which define the purpose of the ritual. It seems that Rudolf's record rather closely conveys the magic formula which was part of the ritual. Obviously, in the original text the forest woman was mentioned and not Fauna, as she was called by Rudolf. Hypothetically, this formula could sound the following way: 'Let your child (or the child of 'the forest woman') cry, and my child be silent'.

There is little or no doubt that the magic spell laconically retold by Brother Rudolf had a longer original form. This produces some reservations about the text under consideration. In particular, it is unclear why the forest woman should accept such an unprofitable offer.

To resolve this question, it is helpful to review the records made in the nineteenth and twentieth centuries, which are significantly more comprehensive than Rudolf's. We have already outlined three basic variations of this type of the spell for children's insomnia. In the most widespread variants of this plot the woman offers the mythological being to exchange the cry of her baby for the sleep of the forest woman's child. That is, the situation is described as an exchange between a representative of the human world and a mythological forest character.

The pragmatic purpose of the magic spell is described in a way as to hide the real aim of the woman and to encourage the forest woman to accept an unprofitable deal. Using the tactic of deception, the performer of the magic spell offers the forest woman a mutually beneficial exchange, which seems to establish a kinship relationship between the human mother and the forest woman. Actually, the aim is to free her own child from crying and to transfer the crying to the child of the forest woman. 
In the texts of the second type, the woman proposes to a mythological being that their children marry, and in the texts of the third group it is suggested that the children have some feelings for each other. In both cases the pragmatic purpose of the magic spell is being concealed. It seems that the tactic of lying was quite acceptable for people who used magic for resolving their own problems and communicated with mythological creatures.

\section{CONCLUSION}

Thus, with the help of magic spells recorded in the nineteenth-twentieth centuries, it is possible to reconstruct hypothetically the inner logic and missing links of the medieval magical text, which Brother Rudolf recorded in an abbreviated form. Keeping in mind that the record not only has separate parallels in Slavic ethnographic materials of the nineteenth and twentieth centuries, but is also an organic part of the Slavic tradition, we could naturally assume that in this case Brother Rudolf received information from the Slavic bearers of tradition, who most likely told him this spell in Polish.

We do not attempt to extrapolate our conclusions about the Slavic origin of just one of Rudolf's records to the entire volume of The Catalog of Magic, but we also believe that it would be incorrect to totally ignore this observation.

The fact that the magic spells for children's insomnia which we analyzed seem to have existed already in the thirteenth or fourteenth century, and that in the nineteenth and twentieth centuries they were widely spread on the broad territory where Eastern, Southern, and Western Slavs lived, testifies to the ancient origins of this type of magic spells and their centuries-old migration on the territory of Eastern, Southeastern, and Central Europe.

\section{Translated by Yelena Minyonok}

\section{ACKNOWLEDGEMENTS}

This work was supported by the Russian Foundation for Basic Research (grant number 20-012-00117, "Russian magic folklore from unpublished sources from the 17th to the start of the 20th century; archival searches, preparation of scientific publication, research, and commentary"). 


\section{REFERENCES}

Agapkina, Tatiana 2010. Vostochnoslavianskie lechebnye zagovory v sravnitel'nom osveshchenii: Siuzhetika i obraz mira. [Eastern-Slavic Magical Healing Spells in Comparative Studies: Plots and the Image of the World.] Moscow: Indrik. Available at https://inslav.ru/images/stories/pdf/2010_Agapkina_Zagovory.pdf, last accessed on 10 September 2020.

Agapkina, Tatiana 2019. Paralleli v oblasti verbal'noi magii u vostochnykh i iuzhnykh slavian. [Parallels in the Sphere of Verbal Magic among Eastern and Southern Slavs.] In: Svetlana Tolstaia (ed.) Slavianskie arkhaicheskie arealy v prostranstve Evropy. Moscow: Indrik, pp. 10-38. Available at https://inslav.ru/sites/default/files/ editions/2019_slavjanskie_arxaicheskie_arealy.pdf, last accessed on 10 September 2020 .

Agapkina, Tatiana \& Toporkov, Andrei 1990. K rekonstruktsii praslavianskikh zagovorov. [To the Recomposition of Proto-Slavic Magic Spells.] In: Boris Putilov (ed.) Fol'klor i etnografiia: problemy rekonstruktsii faktov traditsionnoi kul'tury. Leningrad: Nauka, pp. 67-75. Available at https://www.academia.edu/5268605/K_ реконструкции_праславянских_заговоров, last accessed on 10 September 2020.

Balagur, Iats'ko 1847. Vorozhenie u rusinov. [Working with Magic among Rusyns.] In: Ivan Golovatskii (comp.) Venok rusinam na obzhinki. Part 2. Vienna: O.O. Mekhitaristov, pp. 262-272. Available at http://history-fiction.ru/books/ all_1/region_110_1/book_4340/, last accessed on 10 September 2020.

Barnat, Roman 2000. Problem wierzeń demonologicznych w Katalogu magii Rudolfa. [Problems of Mythological Beliefs in Rudolf's Catalog of Magic.] In: Antoni Barciak \& Teresa Rduch (eds.) Z dziejów Śląska: Zbiór studiów. Katowice: PAN O/ Katowice, pp. 9-27.

Bracha, Krzysztof 2000. Katalog magii Rudolfa (na marginesie dotychczasowych prac). [Rudolf's Catalog of Magic (on the Margins of the Previous Works).] In: Józef Dobosz \& Andrzej Marek Wyrwa (eds.) Cystersi w społeczeństwie Europy Środkowej: Materiaty z konferencji naukowej odbytej w klasztorze oo. Cystersów w Krakowie Mogile z okazji 900 rocznicy powstania Zakonu Ojców Cystersów, Poznań - Kraków - Mogita, 5-10 października 1998. Poznań: Wydawnictwo Poznańskie, pp. 806-820. Available at https://www.academia.edu/39845013/ Bracha_K._Katalog_magii_Rudolfa, last accessed on 10 September 2020.

Budziszewska, Wanda 1982. Fauna z Katalogu magii brata Rudolfa. [Fauna from Brother Rudolf's Catalog of Magic.] Poradnik językowy, Vol. 6, pp. 411-414. Available at https://poradnik-jezykowy.uw.edu.pl/issue/946, last accessed on 10 September 2020.

Grbich, Savatije 1909. Srpski narodni obichaji iz sreza Bolievachkog. [Serbian Folklore Customs from Bolevachkog County.] Srpski etnografski zbornik, Volume 14. Obichai naroda srpskoga. Book 2. Beograd: Drzhavna shtampariia Kralievine Srbiie, pp. 1-382. Available at https://www.antikvarne-knjige.com/elektronskeknjige/ assets/uploads/obicaji-naroda-srpskog-2.pdf, last accessed on 10 September 2020. 
Karwot, Edward 1955. Katalog magii Rudolfa: Źródto etnograficzne XIII wieku. [The Rudolf' Catalog of Magic: An Ethnographic Source of the 13th Century.] Wroclaw: Zakład im. Ossolińskich.

Klapper, Joseph 1915. Deutscher Volksglaube in Schlesien in ältester Zeit. Mitteilungen der Schlesischen Gesellschaft für Volkskunde, Vol. 17, pp. 19-57. Available at https://sbc.org.pl/Content/304952/ii4045-1915-01-0001.pdf, last accessed on 10 September 2020.

M.B. 1867. Sel'skie chary i zagovory - po Podol'skoi gubernii. [Countryside Magic and Magic Spells - in Podolsk Province.] Podol'skie eparkhial'nye vedomosti. Otdel neofitsial'nyi, No. 20, 15 October, pp. 689-695. Available at https://pravoslavnoeduhovenstvo.ru/media/priestdb/materialattachment/attachment/a5/a5/a5a503817b87-4824-9473-517a02a8fd39.pdf, last accessed on 11 September 2020.

Smoczyńska-Reiner, Daria 2007. Świat pogańskich wierzeń ludowych w dziele "Summa de confessionis discretione" brata Rudolfa. [The World of Pagan Folk Beliefs in "Summa de Confessionis Discretione" by Monk Rudolph.] Slavia Antiqua: rocznik poświęcony starożytnościom stowiańskim, Vol. 48, pp. 189-248. Available at http://cejsh.icm.edu.pl/cejsh/element/bwmeta1.element.38f4aa23-d63d3567-aa5d-2e1807dfde0f, last accessed on 11 September 2020.

Talko-Hryncewicz, Julian 1893. Zarysy lecznictwa ludowego na Rusi potudniowej. [Essays on Traditional Medicine in Southern Russia.] Kraków: Nakł. Akademii Umiejętności: Skł.gł. w Księgarni Spółki Wydawniczej Polskiej. Available at https://books.google.ru/books?id=xWvESIvADJ8C\&printsec=frontcover\&hl=ru \#v=onepage\&q\&f=false, last accessed on 11 September 2020.

Vinogradova, Liudmila 1988. Slavianskie zagovornye formuly ot detskoi bessonnitsy. [Slavic Magic Formulas for Insomnia in Children.] Etnolingvistika teksta: Semiotika malykh form fol'klora. Tezisy i predvaritel'nye materialy $k$ simpoziumu. Vol. 1. Moscow: Institut slavianovedeniia i balkanistiki AN SSSR, pp. 82-85. Available at https://inslav.ru/images/stories/pdf/1988_Etnolingvistika_ teksta_\%28Semiotika_malyx_form_folklora\%29_Tezisy.pdf, last accessed on 11 September 2020.

Vinogradova, Liudmila 2016. Mifologicheskii aspekt slavianskoi fol'klornoi traditsii. [Mythological Aspect of Slavic Folklore Tradition.] Moscow: Indrik.

Wereńko, F. 1896. Przyczynek do lecznictwa ludowego. [Contribution to Traditional Medicine.] In: Materiaty antropologiczno-archeologiczne i etnograficzne. T. 1, Dz. 2. Kraków: Nakł. Akademii Umiejętności, pp. 99-228. Available at https://rcin. org.pl/dlibra/show-content/publication/edition/1496?id=1496, last accessed on 11 September 2020.

Tatiana Agapkina is Leading Research Fellow (Sc.D.) at the Institute for Slavic Studies, Russian Academy of Sciences, Moscow, Russia. Her main research areas are calendar rites, ethnobotany, and verbal magic.

agapi-t@yandex.ru 
Andrei Toporkov is correspondent member of the Russian Academy of Sciences, Leading Research Fellow (Sc.D.) at the Gorky Institute of World Literature, Russian Academy of Sciences, Moscow, Russia. His main research areas include Russian and Slavic folklore and history of Russian literature.

atoporkov@mail.ru 


\title{
UNLIVED LIFE: THE DEATH AND FUNERAL OF A CHILD IN SLAVIC TRADITIONAL CULTURE
}

\author{
Irina Sedakova \\ Sc.D., Head of the Department for Typology and Comparative Linguistics \\ Institute for Slavic Studies, Russian Academy of Sciences, Russia \\ irina.a.sedakova@gmail.com
}

\begin{abstract}
This ethnolinguistic study based on the analysis of the archival and field data from various Slavic traditions gives an account of the reasons, meaning, and folk comprehension of untimely death - that of a child. Such a tragic event is seen as a result of intricate reasons: God's will, the fate, the verdict of the Fates, parents' ban on the rules, and lack of veneration of the saints, black magic, the evil eye, curse, etc. The amalgamation of Christian views and the pre-Christian perception of early death brings about a combination of notions that seem to be impossible, even more since fatalism comes along with the simultaneous assurance that an early death can be averted with the help of rites and magic acts performed on a newborn baby. Magic programming of a baby's longevity, which starts with the conception and goes through the delivery and postpartum period, various signs, omens, fortune-telling, and prophetic dreams are scrutinized in the first part of the article. Further on the specifics of the funeral of a baby are analysed, with special attention paid to the magic means to separate the baby from the mother and to prevent the death of other children. The types of commemoration and the obstacles of a baby's fate in the other world are also investigated in terms of reflecting the behaviour of the deceased child's relatives. To conclude, the author depicts the stability of some archaic beliefs which one can observe at a child's funeral, and commemorative practices nowadays.
\end{abstract}

Keywords: childbirth, death, ethnolinguistics, fate, funeral customs, magic, Slavic studies

\section{INTRODUCTION}

The article considers popular ideas and beliefs related to early death (in infancy or in childhood), its causes and ways of prevention. Specific Slavic features of a child's funeral and commemoration, beliefs about their posthumous fate are also analysed. As far as I know, these issues have not been subjected to special investigations. An article by Galina Lozanova is devoted to children's funerals among the Southern Slavs (Lozanova 1989), several publications are devoted to local traditions (see Korolyova 2018); certain chapters on "irregular burials" 
can be found in a series of monographs on life circle rites of the Slavs (Navrátilová 2004; Bizeranova 2013). Some topics related to death and child's funeral are elucidated in ethnolinguistic dictionaries (Tolstoi 1995-2012; Makarijoska 2016). I have drawn upon data of folklore and ethnographic studies, archive materials and my own records, made predominantly among Bulgarians living in Bulgaria and in diasporas, and have used these as my principal material. I do not provide a reference for some widespread and well-known beliefs and ethnographic facts. The situation I am characterizing embraces the end of the nineteenth up to mid-twentieth centuries, though some superstitions are still alive and can be documented in most archaic Slavic regions and even in urban settings.

The main methodology of this study lies within the Moscow (Slavic) Ethnolinguistic School, founded by Nikita Tolstoi in the 1970s, and maintains its popularity with many followers up to the present day. The Slavic Ethnolinguistic School uses a multidisciplinary approach to the linguistic and extra-linguistic facts, adducing data from languages, all folklore genres, beliefs, and rituals.

Before I begin the special analysis of rites and beliefs connected with an early death, I would like to mention, at least briefly, the popular views about a human life term (Russian век) as allotted to a person, i.e., the term of mortal life. A life lived 'normally', as it is thought, ends at a venerable age with a natural death. The life 'unlived', without going through all the life stages (growing into adulthood, being wed, the birth of children and grandchildren, and ageing), taken away by accident - a premature death - is perceived in traditional culture as an anomaly, an aberration, and an unhappy fate of the departed and also of their relatives. Also, the death of a son or a daughter, even if they do not die young, presents a tragic anomaly, a permanent grief, a violation of 'life rules' for the parents who survive their child.

An early departure from life in babyhood, childhood, in adolescence or even at a more mature age, but prior to parental death, is believed to be conditioned by a whole set of reasons. According to beliefs, a child's death is written in his or her fate or even in the fates of their parents that are designated by the Fates or other spirits (Plotnikova \& Sedakova 2012; Sedakova 2012). According to other beliefs, such a premature tragic death is prescribed by God; occasionally the midwife sees it after the baby is born, but with no chance to be changed, since this is His will (Vlaskina 2009: 237). Besides, the Slavs traditionally believed in the effectiveness of the evil eye, spells, curses, and verbal magic. A child may die due to a curse sent during a 'bad time', which came true (Vasilevich 2010: 166). A cause of early death was often thought to be due to the parents' non-compliance (mothers are the more frequent culprits) with recommendations specific to traditional communities (a mother's work during feast days and 
a disregard of patron saints), a neglect of traditional folk restrictions and recommendations that turn unhappy events off, of magic acts against evil spirits, etc.

The amalgamation of Christian views and the pre-Christian perception of early death brings about a combination of contradictory views, i.e., fatalism and the simultaneous assurance that early death can be averted with the help of rites and magic acts that may model a long life for a newborn baby (Sedakova 2012). The modelling of a normal, happy life including longevity is mainly written into the birth ritual scenario. The major intention of the pregnant woman, the mother, is the life and health of her offspring as opposed to death. Magic acts aimed at longevity are at the centre of ritual practice before and after labour. In addition, a great amount of attention is paid to various signs, omens, and fortune-telling, prophetic dreams, life facts, and coincidences that are interpreted predominantly in terms of life and death throughout pregnancy, as well as during and after the childbirth.

\section{PREVENTIVE MEASURES AGAINST EARLY DEATH: DIVINATIONS AND OMENS}

\section{Pregnancy}

The Slavs began to take care of healthy and viable yet-to-be-born children at the wedding and immediately after the wedding. Young couples were forbidden to eat bread brought from burials and commemorational services in the year following their wedding; otherwise their children would not stay on the Earth (would not survive). Each folk tradition specifies unlucky days for conception, so on certain days sexual contacts were forbidden. For example, according to Bulgarian beliefs, a quick death awaited children conceived the night before a Friday, Wednesday, or Saturday (Sedakova 2011: 186).

People feared mentioning and showing off a pregnancy because of the many dangerous things which could be 'done', as was believed, to the mother and the foetus; women would wear wide dresses until it was impossible to hide the belly. This is in drastic contrast to the behaviour of modern mothers-to-be; on the internet, they do declare their pregnant status immediately after it has been confirmed, and wear tight-fitting dresses that show the belly (Sedakova 2016: 171-172).

In traditional views, pregnant women had to follow a number of bans to ensure the safety of their children in the future, and to protect them from accidental deaths due to specific circumstances. Bulgarian women never worked on Fridays to avoid the death of their children by fire; they never sat on the 
place where logs for home ovens were chopped up to avoid the death of their children by an axe, and Serbian women did not take baths in rivers to avoid their children drowning in the future (Sedakova 2011: 186). Byelorussian pregnant women were not allowed to sit down on the well wall nor to bring in home fire from another house, or the child will either hang himself/herself or be drowned (Vasilevich 2010: 48).

A set of ideas and interdictions are known (and occasionally still practiced) to prevent the death of a child due to cord entanglement during birth. To avoid this fate, pregnant women were forbidden to wear beads, to knit, and to step over ropes (Kabakova 2009). It was thought that if a baby born with cord entanglement survived, it would augur an evil event: when the child became an adult, they would either hang themselves or be hanged.

Certain omens were thought to predict an early death of a child, even if they appeared during pregnancy. If black blots were seen on the nails of a pregnant woman or if she wanted to eat fish, it was thought, in the Russian North, that she would give birth to a stillborn child or that her child would die in the mother's womb long before the term of labour was due (Sedakova 1997: 9). Byelorussians believed that if a pregnant woman wanted to eat honey or salted fish, her child would have a short life (Vasilevich 2010: 48). Honey as a commemorational food, the colour black and fish are associated with death; as such the symbolism here is crystal clear.

\section{Labour and postpartum period}

If the childbirth was successful, the mother, the midwife, and occasionally some other people present tried to guess whether the baby would live or not. A child's term of life was related to the phases of the moon at the moment of his or her birth: a young or full moon predicted a long life and a birth after the change of the moon augured an imminent death. The position of the sun was also taken into account: children born after midday, particularly at sunset, were doomed to an early death and were not viable. Days of the week when a birth took place were interpreted differently. It was a widespread belief that early death or serious illness awaited children born on a Friday (Sedakova 2007: 354). The Slavs also thought that the birth, just like the conception, on a Wednesday, Friday, and especially on a Saturday augured an early death and a short life. When a birthday coincided with a big feast like Christmas, Easter, commemorative days, days of funerals of grandparents, and serious losses or damages to a household, or just "an unlucky day", these predicted a short life for a baby (Loginov 1993: 107). Months also had their meanings: according to the beliefs of Eastern Slavs, children born in March would not live long. 
The first sounds of a baby served as a basis for guessing its life expectancy. Byelorussians believed that those who cried out right upon being born would live long, while 'revived' babies (those who had been born silent and had given sounds only after a pause) would be ailing and not viable (Vasilevich 2010: 102).

The appearance of a baby also predicted a great deal about its health and longevity. It was thought that a corpulent, heavy child would not live long because the Earth 'pulled him down', while a 'raw' (i.e. 'unready', 'uncooked') child with a 'dilapidated', 'forked' head and long hair, blunt eye corners, soft ears, and a pointed chin was doomed to an early death or a short life. Feet wet with fat and the skin colour were deemed signs to think about the potential term of a baby's life. White and blue skin, especially on the bridge of the nose, was interpreted as a sign of an imminent, early death.

There are many magic actions in birth rites that were aimed not only at producing longevity but also preventing of evil magic which might cause severe illnesses or death. In Bulgaria, it was forbidden to use black thread for fastening the umbilical cord in order to prevent a child's death (Mikhailova 1986: 212). There are eyewitnesses' accounts that it was forbidden to take out the afterbirth from the yard where a child was born because it was thought that the mother and the newly born child would follow the same path ('feet first') (ibid.: 213). In popular medical ideas the afterbirth was perceived as the child's twin and therefore connected to the child's life. It was believed that if somebody were to dig it out, it might be used for harm and the child could die, while his mother would remain childless forever (Popov 1994: 127).

The choice of name had a magical nature, too, the major intention being longevity (on other aspects of choosing the name see Sedakova 2007: 108-115). The Slavs tried to choose a 'strong' saint's name (George, Michael, Nedelya, Petka, etc.) for a newborn baby, especially if labour was difficult or if the child was particularly desired and impetrated after a long, childless marriage. It was forbidden to name somebody in honour of a saint whose feast had already passed; otherwise the newborn would not live long.

In some regions, it was forbidden to give the same names to children within a family; this foretold an early death to one of the namesakes (Listova 2001: 607,611 ), though it was a widespread practice to give names in honour of living grandmothers and grandfathers among the Balkan Slavs. An exception was made occasionally for the first child born immediately after the death of the person whose name the baby was supposed to take on. Early death was explained by the use of the name of the dead relative. The very name with transparent meaning 'to stay, to survive' often implied opposition to death (e.g. South Slavic names Zhivko, Traiko, Stoian, Stoika; for more details see Tolstoi \& Tolstaia 1998; Krusteva-Blagoeva 1999; Sedakova 2007: 108-128). Names given before 
baptism were kept in secret (Serbs sometimes did that until the wedding), to drive away the evil spirits capable of taking the baby with them.

The first wrapping of a child in diapers was also associated with counteracting death. The idea of a long life could be expressed by the usage of clothes of senior relatives, grandfathers and grandmothers, to make diapers; this transferred the seniors' longevity to the child. For the same reason many Slavs used to put an ancient coin into the water in which a child took a bath (Simonides 1988: 31). Also, white wool was brought to feasts in commemoration of a child's birth. Elderly guests praised the child wishing them health and long life, for example, "Stay healthy, live long like me, until your hair grows white (grey)" (Mikhailova 1999: 365; Popov 1994: 137).

The recommendations for taking care of babies did not contain only positive activity. The set of rules also included actions that warded off evil magic because babies were thought to be the most vulnerable to harm. Particular attention was paid to sleep, in addition to the fact that sleep is required for the normal development of a child (see Agapkina \& Toporkov 2020). In archaic thought, sleep in many respects is tantamount to death, and the cradle is taken as an analogy to coffin (Tsiv'ian 1982). Therefore, people paid attention when a child fell asleep quickly after being placed in the cradle for the first time; if this happened, then an early death was expected. If a child slept with open or semi-open eyes, it was thought that they would not live until their third birthday. There were many bans that existed along with the aforementioned signs. For instance, it was forbidden to demonstrate a sleeping child to those who had not seen them yet; this was done to avert the child's death. The Slavs tried not to bring a cradle into the house before the birth of the first child; they had a universal ban on rocking empty cradles, and one of the explanations was that it was feared to draw death to a child. In a series of items and actions that people associated with death and funeral-commemoration rites, I would like to mention one more warning which is related to the careful treatment of mirrors: the Slavs believed that if a child would see his or her image in the mirror, they would die.

Safety prescriptions also dealt with potential accidents. For instance, mothers were forbidden to touch the house fire for three days after birth to prevent the death of a child caused by fire when the baby begins to crawl. In Bulgarian diaspora in Moldova I put down a memorate about the tragic death of a girl who was eaten by wolves, because her mother had violated the ban to work on the so-called Wolves' Days in November. On these days mothers are not allowed to work so that their children would survive and would not meet wolves (Sedakova 2007: 354). 
Baptism, like birth, is connected with the motifs of life and death through magical acts, omens, and fortune-telling. The time for baptism was chosen specifically: if a child was born during a period of fasting, the christening was postponed to the period of time when the consumption of meat was permitted; otherwise the child would die soon. Those who were invited to bake ritual loaves for birth and baptism celebration were selected carefully: they should not have had recent deaths in the family (Mikhailova 1999: 362). This contributed to the prolongation of the child's bloodline.

Sometimes women died in labour and their children did not survive either; in this case both of them were buried together. The mother passing away had the will to take her child with her to the other world. It is said that the mother of a daughter who had given birth to a child and was departing, asked the daughter what would be done with the child, and got the response: "Don't worry; I'll take it with me". The next day the absolutely healthy baby was found dead; in such a case the child's death was perceived as good: the child was saved from an orphanage or from being a 'superfluous' mouth in an alien family (Bizeranova 2013).

If a mother gave birth to a dead child, it was required to buy calico for 40 shirts or 40 crosses and to dispense them to 40 pregnant women to ensure a better posthumous life for the dead baby (Naumenko 1998: 119).

\section{WHEN A CHILD DIES...}

\section{The perception of a child's death, its reasons and omens}

Views on the death of a child, the ritual complex of his or her burial and commemoration, and the care of the deceased's fate in the other world have much in common with the perception and ritual execution of the natural departure of an aged person (Tolstaia 2012). At the same time there are some specific, 'little' (in literal as well as in figurative sense) moments that make a child's funeral different from the funeral of an adult person.

A. Navrátilová (2004: 244-247) used archaeological data obtained from children's burials, and proved that dead children were perceived as inferior members of society. They did not pass through socializing and thus were not integral members of the society. A child is tightly connected with his or her mother and the family, so the death is written into the family scenario; it changes the status of the parents and influences their fertility in the future. So, a death similar to a birth is not only a physiological act, but a sociological one, too. Mothers and fathers with a dead child, as well as children who had 
a death in the house, were not permitted to take part in many rituals and were restricted from performing some calendar and life cycle customs.

In popular Christian narrations there are texts that explain the reasons for children's death. These interpretations are in line with the explanations of many other phenomena that are presently not still understood. I can adduce a legend told by a Bulgarian elder from the Rouptsi village in 1948 to a girl named Boyana Marinova, who was thirteen or fourteen years old at that time.

Once the Lord, Saint Rangel (Archangel) Michael and the Blessed Mother of God met to discuss and to settle the question in what sequence people should depart to the other world. The Lord said that people should depart in the order of their coming to the Earth, but Saint Rangel interfered and said to the Lord and pleaded him not to interfere since that was not his business. But the Mother of God said that only her words are true and valid, and that there was a need for everybody in the other world, for old people who would take care of the children, and for young people who would work and feed the old and the children. And it became as the Mother of God had said, the old as well as the young, and the children would die. (Bizeranova 2013: 121)

According to the information obtained even as early as the nineteenth and twentieth centuries, under the conditions of indigence and a lack of medical aid, children's mortality was high and a child's death was not an exclusive event. Verbal reactions such as "God has given it and God has taken it away", and "One mouth less", "Thank God, who relieved me of one eater", and "God will not take the soul and it will not leave the body by itself" are known. It was deemed that the parents of a child who died ought not to anger God, otherwise God would not give them any other children. The Slavs knew that their children had been given to God (Bizeranova 2013: 280). The Czechs explained the ban on regretting the death of a child with there being a danger that the child would face an expulsion from Heaven (Navrátilová 2004: 121).

However, even in the poorest families with many children, the departure of a baby was connected with oppressive sorrows that were experienced by mothers with a particular keen. A full integrated analysis of the material in totality makes the ambivalence of the approach evident: on the one hand resignation, the acceptance of death as God's will and the ritual ignoring of death; on the other hand protest, the unacceptance of death reflected with particular intensity in emotional keens for a dead child are observed. A specific situation can be observed in families where children had not stayed alive and several babies had already died. To avoid the death of newborn babies, plenty of ritual actions 
were performed at the death of one of the children in the family as well as at the birth of the next child (Sedakova 1997; Tolstaia 2002).

If a son or a daughter died in infancy, the idea of the whole family's future acquired a particular importance. The departure of a child did not involve the death of other children, and parents were not left alone and childless. Due to those views rigorous regulations were related to the mother in particular as well as to the other participants of the funeral and commemorative actions. Another view of funeral and commemorative rites was focused specifically on the deceased child and their posthumous fate. This also prescribed demanding prescriptions in performing rites.

The causes of an early death could have been lack of hygiene, illnesses, epidemic diseases, or accidents that happened due to lapses of the surrounding people. Even the most natural events were perceived in the context of popular beliefs described above: the evil eye, a curse, the influence of the Fates, a punishment for non-compliance with bans on work on certain days of the week and on feast days, a disregard of saints, the 'errors' of the mother during pregnancy, etc. Such ideas have persisted for a very long time, right up to the present day - people search for a reason to explain their loss. According to field records from Bulgaria, a curse sent to a pregnant woman with the wish for her or for her child to die in labour came true: the following day after the birth of a baby girl, the girl in question died (Bizeranova 2013: 80). In folk songs, the topic of the effectiveness of a curse addressed to an unfaithful girl (or boy) friend is developed (Sedakova 2007: 242). There are many stories of a child's death as a punishment to relatives for the non-compliance with various rules. For instance, people were punished for settling in a new house that had not been blessed yet and soon after that a misfortune came: their child drowned (Popov 2002: 150). Many expeditionary records narrate death as a result of the evil eye, black magic, etc.

Omens of a child's death, as is the case with adults, could occur in the form of prophetic dreams: mothers could have dreams that their hair or one of their breasts was cut off, or that they sustained damage to one of their limbs, that they were standing on the verge of a deep pit, or that they had wandered around the dark woods (Bizeranova 2013: 99-111), or a bird flew off the roof of a house, or a sheep was lost from the herd. One woman had a dream before the death of her grandchild; she saw her late husband who took a piglet from her and carried it away in the same way as one would carry a dead body (Bizeranova 2013: 99). 


\section{Baptized/unbaptized dead babies}

Several parameters affect the perception of a child's death, the ritual execution of their funeral and the regulation of the parents' behaviour. As a rule, the fact of a human's baptism and the giving of a name to him or her was fundamental for Christian society and this fact dictated the instructions for a person's funeral and presaged the posthumous fate. Those "without a cross" (not baptized) and a personal name would go to Hell and would be there as if they "were not born" (Shcherbak 2008: 7). So the striving to baptize a child as soon as possible is understandable; if a baby was born weakened, then the priest would allow the midwife or the mother-in-law to perform the baptism; even the father would be allowed to do this (if the child survived, the complete rite of baptism was performed later).

Much has been written about children who died unbaptized, since the belief that they turn into evil spirits and have a hard post-mortal fate is widely spread in Indo-European mythology. I merely mention the facts that are important in the perspective of an early death and the funeral rites. Unbaptized, and consequently 'nameless' children who died were assigned to be buried in the following places: beneath the house, under a window, in the yard, under a tree in the garden, under a rose bush, in a pound for sheep, in the woods, at a crossroads, usually outside cemeteries, but sometimes also near the fence or in a corner of a cemetery. Such children were buried, predominantly, without a cross. There is plenty of information from the Polesie (an archaic area in Byelorussia and Ukraine) region that unbaptized children were buried under thresholds to make people step over them and this way cross them with legs (BD PA). Occasionally before death (or after it) unbaptized children were given names and sprinkled with holy water; after burial the graves were also sprinkled with holy water (BD PA; Popov 1994; Sedakova O. 2004).

The Slavs' beliefs assert that in the other world, the unbaptized child was blind; they sat on the grass, under a tree. They would not go to Heaven; they would go nowhere. Many Slavic (and, in a wider sense, Indo-European) beliefs are recorded and narrate that unbaptized children turn into daemons, into birds that fly crying out in search of their names (for details see Kabakova 1999: 86-87; Radenkovich 2004; O'Connor 2005), or into horses (Sedakova O. 2004: 255).

\section{Age of the baby and obstacles of death}

The manner in which a child died is particularly important. Children who were accidentally suffocated by sleeping mothers were allocated in a particular group. 
Mothers who did that attempted to pray their sin away; they would spend three nights in church, repenting. In the Smolensk region, people recounted:

One aged woman was stricken for three days and lay as a dead person... then revived. Answering the question "Where have you been?" she responded: "A burial ground was shown to me; and I saw that children who had accidentally suffocated in their sleep had a black flower in their hand, while children who died their own deaths held pink flowers." And it was said to her: "Go and announce that to every mother and tell them not to sleep tightly with their children to avoid such a sin." (Naumenko 1998: 119)

The age of the deceased child determined certain aspects of the ritual execution of the funeral and influenced the ideas of what their post-mortem fate would be like. It was deemed that children who died soon after birth would go to Heaven; moreover, they saved their mothers from Hell (Rks: 306). It was believed that there was an apple tree in Heaven with a multitude of shoots resembling female breasts, and that the departed children would make use of these shoots (Bizeranova 2013: 133). Babies have a particular bond with their mothers; if a baby died, extra measures were taken to prevent his or her visits to the mother for breast milk (the mother hid, did not spend nights at home, etc.). Besides babyhood, in descriptions of funerals and commemorations the following age periods were indicated: younger than 3 years, younger than 7 years, younger than 10 years, younger than 12 years. It is noted that elements of a weddingfuneral are included in the commemoration of the dead who had reached the age of thirteen-fourteen (Lozanova 1989: 20).

Children younger than 7 were deemed innocent, guiltless, and therefore they died easily, with no pain. If a child did experience pain, the cradle was put on the floor beneath the house icon and people said: "Its pain is the result of its labour for its parents' sins".

\section{Rituals and beliefs}

It was not customary to spread the news of a child's death as it was done in the case of an adult person's death; information of the tragic event was available only to family members. No funeral wreath or a cloth as a visual sign of a death in the family was to be hung on the gate. The custom known to many Slavs (when a person living in a village died, members of the community needed to discharge barrels and draft fresh water) was not complied with when a child died (Vakarelski 1990: 77). 
Ukrainians put a child's corpse not on a bench in the room, as it was done with adult corpses, but on a table because the dead child was "like an angel". The child was dressed for its funeral in a special way. Ukrainians covered the dead children's faces with a wrap or a piece of cloth. The funeral shirt was sown with a 'living thread' (without knots), irrespective of gender. In the Poltava region the deceased child was often covered with a krizhmo, i.e., a cloth the godmother presented for the baptismal feast (Shcherbak 2008: 73). More often than not, boys and girls were dressed identically: with no headwear, in white shirts and slippers (Fiadosik 1986: 22, 132; BD PA), but gender differentiation is also known: girls got dresses and boys got long shirts; both girls and boys had wreaths placed on their heads.

Children that had passed away were dressed in completely new, holiday clothes presented by the godmother (Mikhailova 1999: 5, 225, 245), with an obligatorily belt. It is explained that the unbelted child would endure hardship in the other world: if an apple were to be given to a child, they would lose it because they would put the apple under their shirt (Bizeranova 2013: 280; Levkievskaia 2009).

There was a belief that a child who died would still grow. Therefore, the sides of their shirt were not sown or even the shirt was cut to avoid any obstacles to the growth. The idea of posthumous growth was understood demonologically. In the Russian North, people believed that children in the other world might overgrow their fathers if they were not stopped. Such dead corpses could turn into evil spirits and 'walk' and 'frighten' people. To prevent this, a thread as long as the father's (or mother's) height was put into the coffin, so the child would not grow taller than the parent (Listova 2001: 623).

Wood shavings, birch leaves or a pillow stuffed with leaves or thyme were placed into the coffin which was normally unpainted. In the Vologda region, Russia, an egg used to be placed for a little one under the pillow and people said: "Let him play with the egg with joy" (Vlasova 1999: 392).

In Bulgaria, the midwife came without fail to the funeral of a baby. She locked the door latch and put it under the dead child's back while the key was dropped into the well to prevent the death of other children. Sometimes the latch was dropped into the grave in order to expel death and to seal the way for it (Mikhailova 1999: 225).

Children's funerals were modest: the child was carried by the godmother, the midwife or the father (Korepova 2013: 171). The Nekrasov Cossacks who emigrated from Russia to Turkey had a custom according to which the dead child was taken to the cemetery by an orphan girl (orphans were also supposed to dig out the grave (Vlaskina 2016: 91-92). In the Polesie region, a dead child (younger than 7 years old) was taken to the grave by six girls who carried the 
corpse on special blankets (Sedakova O. 2004: 243; Fiadosik 1986: 155). If a child was younger than 10, they were carried by coevals (Korepova 2013: 107).

As an example of the account above, I adduce a short description of an archaic rite of the funeral of a baby who was about one or two months old, from the Gymzovo village in north-western Bulgaria; the funeral took place in the 1960s. The description reflects important moments typical for the perception of a child's death as a significant event in the life of the family. The child (regrettably, the author did not specify whether the child was baptized or not, but supposedly it was 'without a cross') was wrapped in diapers and carried out (feet first) through the window. Then, the corpse was buried in the garden in a place that had not been dug out previously, for nothing had been planted there for a long time. The grave was dug out and the coffin was placed with the deceased's head pointing westward in the grave. Though a cross was not put up, the grave was arranged as it is usually done in the cemetery, and flowers were planted. On commemoration days the grave was avoided. S. Bizeranova, who recorded the rite, quotes the words of a female informant: "Thus people strove to prevent the death of the next child who would be born" (Bizeranova 2013: 218).

\section{To keep fertility in the family}

Having quoted this account, I proceed to a very important part of the topic: customs and rites that were qualified to protect a family that had lost a child from the loss of other children. Whether the firstborn died or there were other children in the family, was deemed as an important circumstance to consider. In any case, a preventive ritual was developed in detail. In the Serbian village Oshlyane, before the deceased child was deposed on the bier, all of the buttons on his or her shirt were unfastened; otherwise their mother would be unable to conceive again. Cases of an inability to conceive explained with the non-compliance with the aforementioned rule have been recorded. To 'correct' this mistake, the grave was exhumed and the buttons were unfastened. The mother soon conceived and gave birth to a healthy baby (Krstich 2003: 155).

When the procession went to the cemetery, somebody had to stay at home to prevent the death of the other children. The door was closed for a minute after people stirred from the house with the same reasoning. All the Slavs banned the participation of the mother and often also the father in the funeral of the firstborn child. Parents were even disallowed to approach the coffin of their child, particularly if the deceased child was the firstborn; the time and the place of the funeral were concealed. A mother would not bury her firstborn; if this ban 
was violated, the mother would bury 'all of the other children'. If a boy died, his grave was circled around three times cum sole to ensure that his mother could give birth to other children. Bulgarians whirled wreaths of geranium and decorated the mother with them, and she danced in the yard "to prevent the evil's joy" after the lifting of the body (Rks: 79).

When a firstborn child died, mourning clothes were not worn for them, though they were worn for subsequent children: Bulgarian men did not wear headgear, girls did not plait their hair, and women did not wear beads and straps for three days. Some parents kept on observing the mourning period until the end of their own lives (Bizeranova 2013: 203, 204, 269, 279).

For a single child in the family a window was cut in the coffin in order not to lock the way to other children. The child's items were destroyed for the same purpose. Southern Slavs' fathers used to burn the cradle behind the mother's back. Diapers were burnt or were given away to the Romany (Popov 1994: 205; 2002: 138). The Bulgarians living in the Sakar region had a custom to destroy the house where the firstborn child died, and to build a new house with the clothes of the deceased put under the foundation (Popov 2002: 138). Southern Slavs practiced a considerable array of magical acts in the case when one of the twins or of the children born in the same month or on the same day, although in another year, died (Plotnikova 2004).

\section{Posthumous acts and commemorations for the children}

Food for children, sweets, eggs, and milk were put on the table at wakes and subsequent commemorations. Fruits were left at the grave and the grave was watered. The custom to dispense food on commemorative days (it was an accepted practice among the South Slavs) presupposed the baking of special loaves, but these were smaller; Byelorussians baked special biscuits called ladki to prevent the deaths of other children in the family (Fiadosik 1986: 170). There are many interesting local and ethnic details regarding the way and the kind of the food served for the children. The Cossacks from the Don Delta would not lay the table, but put the bowls with sweet milk and egg pasta on the floor or on a meadow covered with a cloth. This food was cooked especially for the children of the same age as the deceased child was (Matishov et al. 2012: 179-180). As Albert Baiburin argues, a commemorative meal placed close to the earth was usually meant for those who had not died in a normal way and untimely (Baiburin 1983: 156).

Age-mates of the deceased were gathered at wakes and remnants of the commemorative food were given to a child of the same gender as the deceased one. 
Children performed an important role in funeral and commemorative rites, particularly if they were age-mates of the deceased child. There was a custom among Romanian Old Believers I documented in Tulcha in 2007: the mother would select a child of the same gender and age as her deceased child, and make presents and clothes for him or her for every feast. At Whitsun, the parents of the deceased child gathered children of the same age and treated them to food and sweets. Living children are actually intermediaries between parents and their deceased children. A particular piece of evidence of this might be the following dream: the mother of a deceased child dreamed that he carried plenty of cookies; she asked where the boy got the cookies and he answered that these were the cookies that she had bought and dispensed (Korepova 2013: 182).

Information and field materials on the terms and dates of commemoration are contradictory. For example, according to the data adduced by S. Bizeranova, in north-western Bulgaria a deceased child was not commemorated after the fortieth day (Bizeranova 2013: 280-281). But there is information that in another region of Bulgaria, in Lovech, a mother who had lost her child visited all of the funerals in her village and bewailed her child (Mikhailova 1999: 416). However, the commemoration of a deceased child (not only a baby but also an adult one who died before parents) for the rest of the mourner's life was more widespread.

Bulgarians believe that a deceased child remains with his or her mother until the fortieth day. On that day, the Mother of God tries to separate the child from the mother but the child cries and does not want to follow the Mother of God. She then throws an apple and the child chases it. A well-known restriction bans the mothers whose child has died to eat apples until the Feast of Transfiguration of Our Lord (August 6/19). People believe that the Mother of God dispenses apples only to those children whose mothers follow the recommendation and deprive those children whose mothers do follow the restriction (Belova 2012). We can see some allusions to it in the habit of the Byelorussian mothers who have lost their children: they leave the first three seasonal berries they have gathered on the ground (Vasilevich 2010: 166).

\section{The child in the other world}

The relatives and villagers comment on the posthumous fate of deceased children in detail. A deceased child is deemed to be 'pure from sin' and is perceived as an 'angel', a cherub; though there are differences that depend on the age of the child. For instance, Russians believe that children of two-three years of age become angels by all means, while a child of seven years of age will go 
to Heaven (Naumenko 1998: 116). If a child reaches eight years of age, then their fate is determined "in accordance with their sins" (Shcherbak 2008: 73).

In any case, a deceased person of any age is 'the ancestor': "Be it a baby, or a youngster three years old, it is the servant of God nevertheless" (Korepova 2013: 161). This idea is important for the understanding of the relations between the child and the other dead ('ancestors'), and with those who are still alive. Help for the dead was sought from 'ancestors'; if in the family an adult person died, they were pleaded to take under their protection all the children and youngsters who had died earlier.

It is believed that a child's soul, until the fortieth day, would appear in the form of an insect, a fly, a butterfly or a cricket. Everybody watches where the insects fly to; it is believed that they will go to Heaven. Back in 1983, in a Bulgarian village in Moldova, I was interviewing a woman whose daughter had died two weeks earlier. A butterfly had flown into the room, and the lady immediately reacted: "See, my daughter Mariyka's soul has come to see us."

Tears and lamentations are the frequent motifs in the description of a child's funeral. It is said that until death came, nobody was allowed to cry (the same behaviour was prescribed in the case of an adult's death). However, the reasoning is different: if a dead person is bemoaned, they will descend to a great depth; if they are not bemoaned, they will be translated into Heaven. But people were absolved of crying for the dead because they were angels (Sedakova O. 2004: 170). According to Croatian beliefs, a mother's tears must not get onto the coffin, otherwise the child would sink in the other world or would wear a wet shirt the whole time there (Alaupović-Gjeldum 1999: 156). The ban on tears for a deceased child was explained by the following reasons: the deceased would sink or lie in water. Dreams related to this topic are frequently narrated; for instance, a woman saw her daughter walking along a flooded road; the water had reached her neck and she was close to drowning. An old woman (a grandmother) interpreted the dream and said: "Do not sob; you will sink her in your tears" (Korepova 2013: 181). To stop a mother's longing for her deceased child, charms were read. The grief was 'washed off' in bathhouses where the parents went after the wake, and sand from the grave was scattered beneath the mother's collar; earlocks were sewn up in a small pouch which the mother would then wear on her body. 


\section{CONCLUSION}

The death of a child is an infrequent event now, but its tragic nature surpasses the traditional perception expressed in the saying "God has given, God has taken away". Present-day records bear witness that the beliefs have retained their archaic features in many respects; an early death causes oppressive sorrows for parents and other relatives who are eager to find a logical reason for the tragic event until the end of their lives.

Motifs of an early departure and a life unlived intensify in lamentations over a child. These motifs are transferred by virtue of metaphors, through addressing the child as a premature berry, a cherry, an apple, etc. (Fiadosik 1986: 315; Koval'-Fuchilo 2012: 303, 647).

Deep grave emotions, strict regulations for the performance and behaviour in the family, fear for the future of the deceased person in the other world are typical of all the deaths as perceived in an archaic society. The difference would be in the size of everything that surrounds the death of a child - less information in the village, smaller processions and commemoration rituals.

Infantile motifs have been retained in the present-day funeral and commemorative practices with some innovations. The motif of a 'tiny one' is still dominating: toys, sweets, and other dainties are brought to children's graves, and the names inscribed on monuments (tombs) are pet and diminutive forms (see Russian Lilichka, Tomochka, Bulgarian Dimo, Shushi) (Fig. 1).

Figure 1. A grave of a girl called Lilichka at the Pyatnitskoe cemetery in Moscow. Photograph by Irina Sedakova 2019.

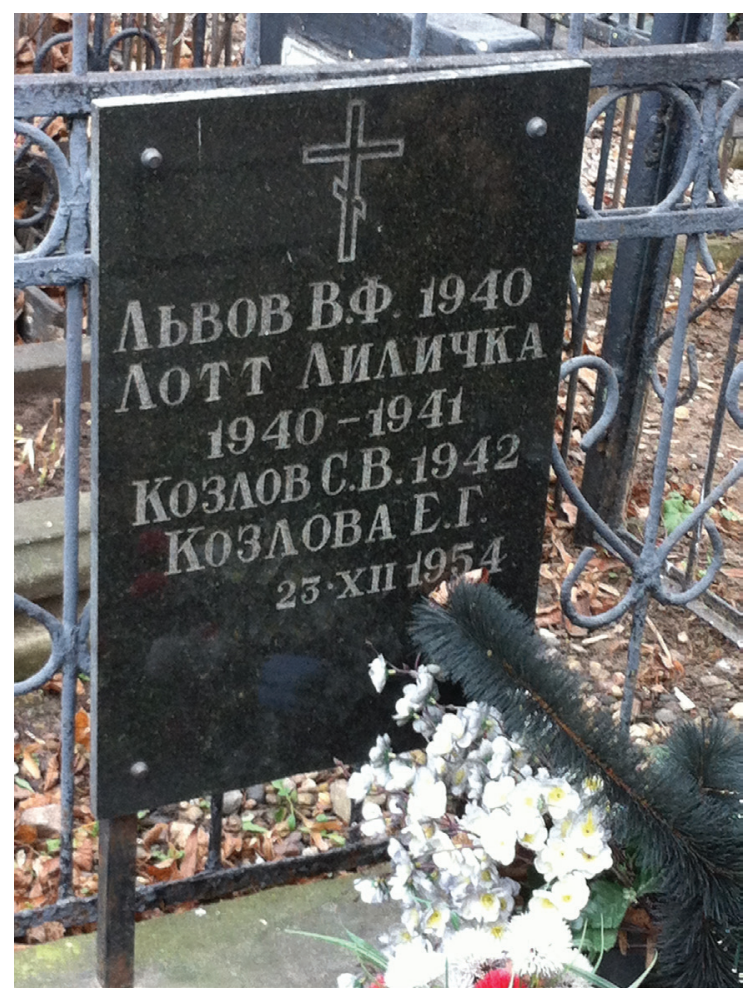




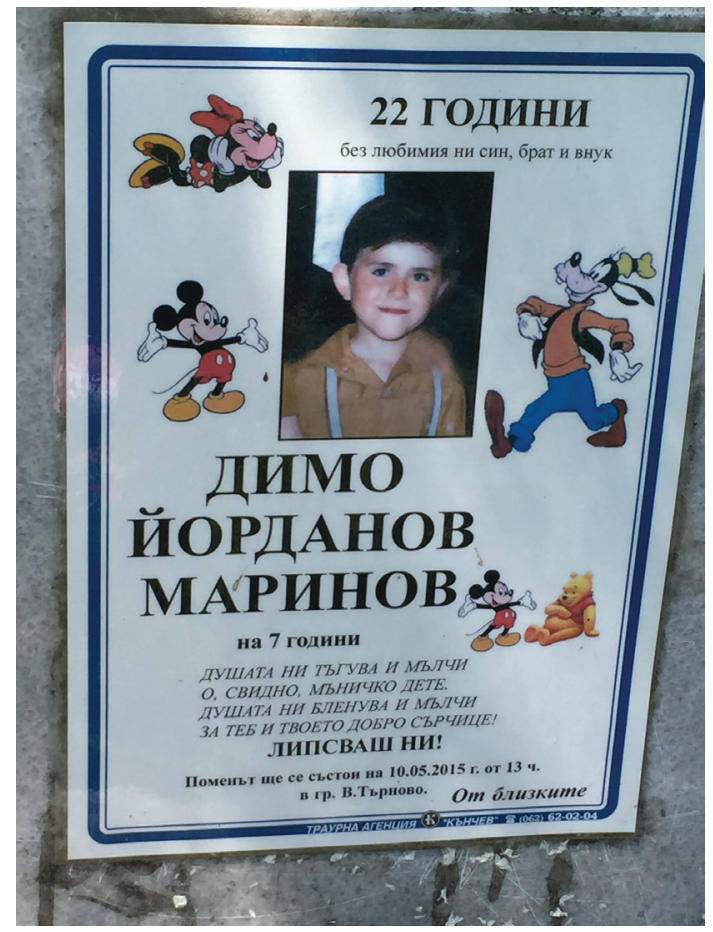

Figure 2. A Bulgarian obituary for a boy of 7 years. Veliko Tarnovo cemetery. Photograph by Irina Sedakova 2017.

Heroes of fairy-tales and decorative elements dominate in obituaries that are widespread in Bulgaria and Northern Macedonia (Fig. 2).

The elements that allude to childhood have particular strong expressions in the commemorations of tragic situations that took many lives, as it happened in the Beslan school act of terrorism, the fire at the "Winter Cherry" mall in Kemerovo, the mass death of children due to bad weather and lack of expertise of the instructors at Lake Syamozero in Karelia, etc.

\section{ARCHIVAL SOURCES}

BD PA = Database "Polessian Archive". Institute for Slavic Studies, Russian Academy of Sciences

Rks = Archival collection of graduate theses written under the guidance of Academician Stefan Romanski. Sofia University "St. Kliment Ohridski” 


\section{REFERENCES}

Agapkina, Tatiana \& Toporkov, Andrei 2020. The Structure and Genesis of One Type of Magic Spell against Children's Insomnia among Slavic Peoples. Folklore: Electronic Journal of Folklore, Vol. 80, pp. 35-46. https://doi.org/10.7592/ FEJF2020.80.agapkina_toporkov.

Alaupović-Gjeldum, Dinka 1999. Običaji zivotnog ciklusa u Imotskoj krajini i zapadnoj Hercegovini, od konca XIX. stoljeća do Drugog svjetskog rata. [Life Cycle Customs in the Region of Imotski and Western Herzegovina from the End of the 19th Century to World War II.] Ethnologica Dalmatica, Vol. 8, pp. 149-168. Available at https://hrcak.srce.hr/file/159857, last accessed on 3 November 2020.

Baiburin, Al'bert 1983. Zhilishche v obriadakh i predstavleniiakh vostochnykh slavian. [Housing in the Rituals and Beliefs of Eastern Slavs.] Leningrad: Nauka. Available at https://eusp.org/sites/default/files/archive/et_dep/Baiburin/baiburin_ zhilishe_v_obriada.pdf, last accessed on 3 November 2020.

Belova, Ol'ga 2012. Iabloko. [Apple.] In: Nikita Tolstoi (ed.) Slavianskie dreunosti: etnolingvisticheskii slovar'. Vol. 5. Moscow: Mezhdunarodnye otnosheniia, pp. 608-611. Available at https://vk.com/doc35528094_464711466?hash=48064 84bb6725d6c54, last accessed on 3 November 2020.

Bizeranova, Sashka 2013. Mezhdu zhivota i smurtta: Pogrebalni i pomenalni obichai pri bulgari i vlasi vuv Vidinsko. [Between Life and Death: Funeral and Memorial Customs among Bulgarians and Vlachs in the Vidin Region.] Vratsa: Aleksprint.

Fiadosik, Anatol' (ed.) 1986. Pakhavanni. Paminki. Galashenni. [Funeral. Commemoration. Lamentation.] Minsk: Navuka i tekhnika.

Kabakova, Galina 1999. Deti nekreshchenye. [Unbaptized Children.] In: Nikita Tolstoi (ed.) Slavianskie dreunosti: etnolingvisticheskii slovar'. Vol. 2. Moscow: Mezhdunarodnye otnosheniia, pp. 86-88. Available at https://vk.com/doc83903602_438147196?hash=23372cb20d6c57b799, last accessed on 3 November 2020.

Kabakova, Galina 2009. Pupovina. [Umbilical Cord.] In: Nikita Tolstoi (ed.) Slavianskie drevnosti: etnolingvisticheskii slovar'. Vol. 4. Moscow: Mezhdunarodnye otnosheniia, pp. 353-354.

Korepova, Klara (ed.) 2013. Fol'klor Sosnovskogo raiona Nizhegorodskoi oblasti. [Folklore of Sosnovskoe District of Nizhniy Novgorod Region.] Nizhniy Novgorod: Rastr-NN.

Korolyova 2018 = Koroleva, Svetlana. "V golbche-to u nas mogil'nik": detskie zakhoroneniia vne obshchego kladbishcha v XX veke (praktiki i narrativy Severnogo Prikam’ia). ["There Are Graves in Our Cellar": Burials of Children Outside Common Cemeteries in the 20th Century (Practices and Narratives of Northern Kama River Basin).] Traditsionnaia kul'tura, Vol. 19, No. 3, pp. 138-149. Available at http://www.trad-culture.ru/sites/default/files/files_pdf/korolyova_0.pdf, last accessed on 3 November 2020.

Koval'-Fuchilo, Irina (ed.) 2012. Golosinnia. [Lamentations.] Kyiv: In-t mistetstvoznavstva, fol'kloristiki ta etnologiï.

Krstich, Dejan 2003. Obichaji i verovanja vezani za smrt u selu Oshljane. [Customs and Beliefs in Connection with Death.] Razvitak, Vol. XLIII, No. 213-214, pp. 147-168. 
Krusteva-Blagoeva 1999 = Krusteva-Blagoeva, Evgeniia. Lichnoto ime v bulgarskata traditsiia. [Personal Name in the Bulgarian Tradition.] Sofia: Akademichno izdatelstvo "Professor Marin Drinov".

Levkievskaia, Elena 2009. Poias. [Belt.] In: Nikita Tolstoi (ed.) Slavianskie drevnosti: etnolingvisticheskii slovar'. Vol. 4. Moscow: Mezhdunarodnye otnosheniia, pp. 230-233.

Listova, Tatiana 2001. Obriady i obychai, sviazannye s rozhdeniem i vospitaniem detei. [Rituals and Customs Associated with the Birth and Upbringing of Children.] In: Irina Vlasova (ed.) Russkii Sever: Etnicheskaia istoriia i narodnaia kul'tura XII-XX veka. Moscow: Nauka, pp. 575-660. Available at http://static.iea.ras.ru/ books/Russian_North_Part_2.pdf, last accessed on 4 November 2020.

Loginov, Konstantin 1993. Semeinye obriady i verovaniia russkikh Zaonezh'ia. [Family Rituals and Beliefs of the Russians in Zaonezhye.] Petrozavodsk: Karel'skii nauchnyi tsentr RAN.

Lozanova, Galina 1989. Osobenosti na obredite pri pogrebenie na detsa u iuzhnite slaviani $v$ kraia na XIX i nachaloto na XX $v$. [Specificities of the Funerary Rites for Children among the Southern Slavs in the Late 19th and Early 20th Century.] Bulgarska etnologiia, No. 1, pp. 17-30. Available at https://www.ceeol.com/search/articledetail?id=226857, last accessed on 4 November 2020 .

Makarijoska, Liljana 2016. Rechnik na makedonskata traditsionalna kultura. [Dictionary of Macedonian Traditional Culture.] Skopje: Institut za makedonski jazik "Krste Misirkov".

Matishov, Gennadii \& Vlaskina, Tatiana \& Venkov, Andrei \& Vlaskina, Nina 2012. Sotsial'no-istoricheskii portret del'ty Dona: kazachii khutor Donskoi. [A SocialHistorical Portrait of the Don Delta: A Cossack Hamlet of Donskoi.] Rostov-onDon: Izdatel'stvo IuNTs RAN.

Mikhailova, Ganka (ed.) 1986. Plovdivski krai: Etnografski i ezikovi prouchvaniia. [Plovdiv Region: Ethnographic and Language Studies.] Sofia: BAN.

Mikhailova, Ganka (ed.) 1999. Loveshki krai: materialna i dukhovna kultura. [Lovech Region: Material and Spiritual Culture.] Sofia: Akademichno izdatelstvo "Professor Marin Drinov".

Naumenko, Georgii 1998. Etnografiia detstva: sbornik fol'klornykh $i$ etnograficheskikh materialov. [Ethnography of Childhood: Collection of Folklore and Ethnographic Materials.] Moscow: Belovod'e.

Navrátilová, Alexandra 2004. Narození a smrt v české lidové kultuře. [Birth and Death in the Czech Folk Culture.] Praha: Vyšehrad.

O'Connor, Anne 2005. The Blessed and the Damned: Sinful Women and Unbaptised Children in Irish Folklore. Bern \& Oxford \& New York: Peter Lang.

Plotnikova, Anna \& Sedakova, Irina 2012. Sudzhenitsy. [The Fates.] In: Nikita Tolstoi (ed.) Slavianskie drevnosti: etnolingvisticheskii slovar'. Vol. 5. Moscow: Mezhdunarodnye otnosheniia, pp. 199-203. Available at https://vk.com/doc35528 094_464711466?hash=4806484bb6725d6c54, last accessed on 3 November 2020.

Plotnikova, Anna 2004. "Odnomesiachniki", "odnodnevniki”. ["Born in One Month", "Born on One Day”.] In: Nikita Tolstoi (ed.) Slavianskie drevnosti: etnolingvisticheskii slovar'. Vol. 3. Moscow: Mezhdunarodnye otnosheniia, pp. 533-534. Available at https://vk.com/doc-83903602_438147292?hash=1572836179c1dabeeb, last accessed on 3 November 2020. 
Popov, Rachko (ed.) 1994. Rodopi: Traditsionna i sotsialnonormativna kultura. [Rhodopes: Traditional and Social-Normative Culture.] Sofia: BAS.

Popov, Rachko (ed.) 2002. Sakar: Etnografsko, folklorno i ezikovo izsledvane. [Sakar: Ethnographic, Folklore and Linguistic Research.] Sofia: Akademichno izdatelstvo "Professor Marin Drinov".

Radenkovich, Liubinko 2004. Nazvaniia demonov, vedushchie proiskhozhdenie ot detei umershikh do kreshcheniia, u slavian. [The Slavic Names of Demons, Originating from Children Who Died before Baptism.] Balcanica, Vol. XXXIV, pp. 203-221. Available at http://www.balcanica.rs/balcanica/uploaded/balcanica/balcanica\%20 34/13\%20Ljubinko.pdf, last accessed on 4 November 2020.

Sedakova, Irina 1997. "Zhilets" - "nezhilets". Magiia i mifologiia rodin. [Survivor or NonSurvivor: Magic and Mythology in Birthlore.] Zhivaia starina, No. 2, pp. 9-11. Available at https://yadi.sk/i/6mIlTALK3P9vrA, last accessed on 4 November 2020 .

Sedakova, Irina 2007. Balkanskie motivy v iazyke i kul'ture bolgar: Rodinnyi tekst. [Balkan Motifs in Bulgarian Language and Culture: Birthlore.] Moscow: Indrik. Available at https://inslav.ru/publication/sedakova-i-balkanskie-motivy-v-yazykei-kulture-bolgar-rodinnyy-tekst-m-2007, last accessed on 4 November 2020.

Sedakova, Irina 2011. Kategoriia vremeni v slavianskom "tekste rozhdeniia": zachatie i beremennost'. [Category of Time in the Slavic "Text of Birth": Conception and Pregnancy.] In: Svetlana Tolstaia (ed.) Prostranstvo i vremia v iazyke i kul'ture. Moscow: Indrik, pp. 181-197. Available at https:/inslav.ru/sites/default/files/ editions/2011_prostranstvo_i_vremja.pdf, last accessed on 4 November 2020.

Sedakova, Irina 2012. The Notion of Fate (Russian cyдьбa) in Slavonic Folk Tradition: An Ethnolinguistic Approach. Cosmos: The Journal of the Traditional Cosmology Society, Vol. 28, pp. 154-169. Available at https://www.academia.edu/10810716/, last accessed on 4 November 2020.

Sedakova, Irina 2016. Clothes as Symbolic and Magic Objects in Slavic Childbirth Customs. Folklore: Electronic Journal of Folklore, Vol. 66, pp. 165-174. https:// doi.org/10.7592/FEJF2016.66.sedakova.

Sedakova, Ol'ga 2004. Poetika obriada: Pogrebal'naia obriadnost'vostochnykh i iuzhnykh slavian. [Poetics of the Ritual: Funeral Ritual Complex of Eastern and Southern Slavs.] Moscow: Indrik. Available at http://www.olgasedakova.com/books/1359, last accessed on 4 November 2020.

Shcherbak, Inna 2008. Obriadovi formi statevoi identifikatsiï ditei. [Ritual Forms of Children's Status Identification.] In: Marina Grimich (ed.) Narodna kul'tura ukraïntsiv: zhittevii tsikl liudini. Tom 1. Diti. Ditinstvo. Ditiacha subkul'tura. Kyiv: Dulibi, pp. 60-81.

Simonides, Dorota 1988. Od kolebki do grobu. Śląski wierzenia, zwyczaje i obrzędy rodzinne $w$ XIX wieku. [From the Cradle to the Grave: Silesian Childbirth Beliefs, Customs and Rituals in the 19th Century.] Opole: Instytut Ślaski w Opolu.

Tolstaia, Svetlana 2002. "Ako se detsa ne drzhe": magicheskie sposoby zashchity novorozhdennykh ot smerti. ["If Babies Die": Magic Preventive Ways of the Death of Newborns.] Kodovi slovenskikh kultura, Vol. 7, pp. 55-87. Available at https:// www.rastko.rs/rastko/delo/11884, last accessed on 4 November 2020. 
Tolstaia, Svetlana 2012. Smert'. [Death.] In: Nikita Tolstoi (ed.) Slavianskie drevnosti: etnolingvisticheskii slovar'. Vol. 5. Moscow: Mezhdunarodnye otnosheniia, pp. 5871. Available at https://vk.com/doc35528094_464711466?hash=4806484bb6725d 6c54, last accessed on 3 November 2020.

Tolstoi, Nikita (ed.) 1995-2012. Slavianskie drevnosti: etnolingvisticheskii slovar'. [Slavic Antiquities: Ethnolinguistic Dictionary.] Vol. 1-5. Moscow: Mezhdunarodnye otnosheniia.

Tolstoi, Nikita \& Tolstaia, Svetlana 1998. Imia v kontekste narodnoi kul'tury. [Name in the Context of Folk Culture.] In: Problemy slavianskogo iazykoznaniia. Tri doklada $k$ XII Mezhdunarodnomu s"ezdu slavistov. Moscow: Institut slavianovedeniia RAN, pp. 88-125. Available at https://inslav.ru/publication/ problemy-slavyanskogo-yazykoznaniya-tri-doklada-k-xii-mezhdunarodnomusezdu-slavistov-m, last accessed on 4 November 2020.

Tsiv'ian, Tatiana 1982. Prostranstvo i vremia v balkanskikh okhranitel'nykh obriadakh, sviazannykh s rozhdeniem rebenka. [Space and Time in the Balkan Preventive Rituals Related to Childbirth.] Makedonski folklore, Vol. 29-30, pp. 117-123.

Vakarelski, Khristo 1990. Bulgarski pogrebalni obichai: Sravnitelno izuchavane. [Bulgarian Funeral Customs: A Comparative Study.] Sofia: Izd-vo na BAN.

Vasilevich, Uladzimir (comp.) 2010. Zhytstsia advechny lad: Belaruskiia narodnyia prykmety i paver'i. [The Traditional Way of Life: Byelorussian Folk Omens and Beliefs.] Vol. 2. Minsk: Belarus'.

Vlaskina, Nina 2009. Kontsept Sud'ba v iazyke i kul'ture donskikh kazakov. [The Concept of Fate in the Language and Culture of the Don Cossacks.] In: Anastasiia Stakheeva \& Nina Vlaskina. Funktsional'nye i etnokul'turnye aspekty izucheniia russkogo iazyka. Rostov-on-Don: Izd-vo IuNTs RAN, pp. 167-373.

Vlaskina, Tatiana 2016. Predstavleniia kazakov-nekrasovtsev o smerti. [Concept of Death among the Nekrasov Cossacks.] Traditsionnaia kul'tura, No. 4 (64), pp. 86-97. Available at http://www.trad-culture.ru/sites/default/files/files_pdf/0 7\%D0\%92\%D0\%BB\%D0\%B0\%D1\%81\%D0\%BA\%D0\%B8\%D0\%BD\%D0\%B0.pdf, last accessed on 4 November 2020.

Vlasova, Marina 1999. Russkie sueveriia. [Russian Superstitions.] Moscow: Azbuka.

Irina Sedakova, $\mathrm{PhD}$, Sc.D., is Head of the Department for Typology and Comparative Linguistics, Institute for Slavic Studies, Russian Academy of Sciences, Russia. Her fields of interest are Slavic and Balkan studies, ethnolinguistics, sociolinguistics, folklore, childbirth and calendric customs.

irina.a.sedakova@gmail.com 


\title{
CHILD IN THE NATAL NARRATIVES OF MODERN UKRAINIAN MOTHERS: FOLKLORIC SYMBOLS AND FREQUENT MOTIFS
}

\author{
Oksana Labashchuk \\ PhD, Professor, Department of Theory and Methods of the Ukrainian \\ and World Literature \\ Ternopil Volodymyr Hnatiuk National Pedagogical University, Ukraine \\ lov081168@elr.tnpu.edu.ua
}

\section{Halyna Derkach}

PhD, Assistant Professor, Department of Foreign Languages

Ternopil Volodymyr Hnatiuk National Pedagogical University, Ukraine halder@tnpu.edu.ua

\section{Tetiana Reshetukha}

PhD, Assistant Professor, Department of Journalism

Ternopil Volodymyr Hnatiuk National Pedagogical University, Ukraine reshtetyana@tnpu.edu.ua

\begin{abstract}
The article focuses on the manner natal narratives accumulate and transmit prevailing traditional ideas about motherhood and the baby in modern society. It lists and exemplifies the major motifs that are typical of oral tradition of the Ukrainians, Slavs, and other peoples. This research is based on stories of more than 500 women about personal experience of pregnancy and childbirth, which were recorded using the narrative interview method. The thick description method (Clifford Geertz 1973) has been applied for material interpretation. The authors analyse animal-child symbolism in the narration of pregnancy, the accents on weather and time while telling about the moment of birth, and the manifestation of each child's uniqueness in the mother's interpretation.
\end{abstract}

Keywords: childbirth, maternal daily life, narrative interview, natal narrative, oral tradition, pregnancy, thick description

\section{INTRODUCTION}

The narratives of pregnancy and childbirth reflect the woman's daily life in the context of a remarkable and extraordinary event in her life. In today's Ukrainian society, everything that accompanies the expectation and birth of 
a child is extremely relevant and is always emotionally coloured. The object of the following research is women's oral stories about their pregnancy and delivery of a baby, recorded in the form of a narrative interview. The subject of our research is the content of the stories about pregnancy and childbirth. The unit of the analysis is the text of a narrative interview, i.e., the natal narrative.

The topics of pregnancy, birth, and baby care have attracted the attention of folklorists, ethnographers, and anthropologists for a long time. As the article focuses on Ukrainian data, we should first mention here the numerous publications on the traditional maternity rituals of the Ukrainians (Boriak 2001; Chubinskii 1877; Gavriliuk 1981; Gvozdevich 1997; Iashchurzhinskii 1893; Kaindl 2000; Kravchenko 1928; Malinka 1898; Mushinka 1961; Onishchuk 1912; Shekerik-Donikiv 1918). For our study, the publication of records by Marko Grushevskii is considered to be the most significant, since it contains not only ethnographic materials, but also a detailed recording of "conversations of women in the countryside", i.e., stories about pregnancy and childbirth, coming from the lips of the people (Grushevskii 1906, 1907).

The anthropological turn from the analysis of the rural maternity rite in archaic cultures towards modern urban societies is of particular importance for our study. Anthropologists scrutinize the contemporary women's experience of giving birth in maternity hospitals, as well as the social institution of motherhood in general (Belousova 1998; Budrowska 2000; Davis-Floyd 1992; Krugliakova 2001; Rich 1976; Shchepanskaia 1999; Thurer 1994). One of the research areas in the modern anthropology of birth is the study of narratives about delivering a baby. It has been elaborated in different countries: the USA (Bird 1994; Davis-Floyd 1992; Miller 2005; Rich 1976; Thurer 1994), Poland (Budrowska 2000; Florek 2007; Zielińska 2007), Russia (Belousova 1998, 2003; Razumova 2000), Finland (Marander-Eklund 2000, 2020), etc. This topic is also being discussed at academic meetings, among which the conference "Retelling Familiar Tales of Pregnancy and Birth in European Cultures", held at Oxford University in July 2012, is the most significant.

Nowadays, scholars pay attention to the potential of modern folklore to express hidden symbolic values (Bogdanov 2001; Cherednikova 2002; OrszulakDudkowska 2008; Orshuliak-Dudkovska 2010). Mothers' stories about their personal experience of childbirth contain concepts, beliefs, and stereotypes which reflect our contemporaries' symbolic picture of the world. In this article, the most important semantic elements manifested in birthlore narratives are touched upon. 


\section{MATERIALS AND METHODS}

The methodological approach used for the analysis of the semantics of the natal narrative is partly developed on the basis of the Interpretation of Cultures by American anthropologist Clifford Geertz (1973). Geertz considers Max Weber's statement that a person can be interpreted as an animal "suspended in the webs of significance he himself has spun" (Geertz 1973: 5) as the key to understanding such phenomena. Geertz explains his point of view in the following way:

I take culture to be those webs, and the analysis of it to be therefore not an experimental science in search of law but an interpretive one in search of meaning. It is explication I am after, construing social expressions on their surface enigmatical. (ibid.)

The specificity of our approach to the analysis of the semantics of the natal narrative is based on the identification of meanings in the oral text. Traditional ethnography or anthropology would seek to identify the meaning on the basis of the analysis of the maternal rite or certain forms of social organization, but we are interested in semantic and symbolic layers, which can be found in the text of a woman's story about the experience of pregnancy and childbirth.

Humans inherit the existing cultural symbolic patterns, adding to them a speck of their own designs, based on their personal experience and background. Human behaviour is formed under the influence of two forces: on the one hand phenomena and processes caused by the innate mechanisms, and on the other those (phenomena and processes) controlled by the mechanisms of culture. People can neither perceive nor interpret their individual bodily experiences without alluding to the semiotic basis provided by the culture:

Between what our body tells us and what we have to know in order to function, there is a vacuum we must fill ourselves, and we fill it with information (or misinformation) provided by our culture. The boundary between what is innately controlled and what is culturally controlled in human behavior is an ill-defined and wavering one. (Geertz 1973: 49-50)

People need to semiotize the phenomena occurring to them, thus the experience of pregnancy and childbirth, which in themselves are physiological processes, can be understood and mastered by women through certain cultural mechanisms. Geertz regarded culture as a peculiar context on the grounds of which the phenomena of social life and the behaviour of individuals can be studied. This method is known as "thick description" (Geertz 1973: 10). In our work with the material, we also rely on the contextual approach suggested by Elizabeth Calvert Fine (1984) and Oleksandra Britsina (2006). 
A number of scholars emphasize the importance of the narrative interview method in folklore studies; this method has been the most appropriate for our investigation. Modern folklorists actively use the strategy of autobiographical interview in their research (Orshuliak-Dudkovska 2010; Simonides 1973). For this reason Jeff Todd Titon's suggestion “to define and develop an approach to the life story as a self-contained fiction, and thus to distinguish it sharply from its historical kin: biography, oral history, and the personal history (or "life history" as it is called in anthropology)" is worth mentioning (Titon 1980: 276). Robert Atkinson emphasizes the role of stereotypical scenarios, universal elements, and personal mythology in telling people's life stories (Atkinson 1995), and so does Tatiana Dianova using Russian data (Dianova 2009). Personal narratives are an important source for folklorists in their study of "the social construction of the self through time and the transformation of experience through materials readily at hand" (Kirshenblatt-Gimblett 1989: 142). Elliott Oring writes about the uniqueness of individual life stories as one of the ethnological genres (Oring 1987).

For the aims of the research presented in this article, the collector's conversation with informants was recorded on digital media and then transcribed in accordance with current requirements to preserve lexical, grammatical, and syntactic features of a narrator's speech.

The method of conducting a narrative interview involves the following steps: posing an open question; careful listening to a narrative; non-interference in conversation (except phrases showing the interviewer's active interest). At the end of an interview it was allowed to put first open and then closed questions. For us the method of dividing the recorded stories into separate blocks and segments, which facilitates further research interpretation, has been very useful (Grinchenko 2007).

In total, we interviewed about 500 women who had experienced pregnancy and childbirth. Some narrators were re-recorded. Interviews were conducted in the years 2006-2016. Our respondents are women who mainly live in the western regions of Ukraine. For ethical reasons, we encrypted their surnames, first names, and patronymics in the attached list of informants. ${ }^{1}$ This allows us to keep privacy and confidentiality of the narrators' personal data.

The purpose of this paper is to evaluate the possibilities of contemporary personal narrative usage for the interpretation of today's women's experience associated with childbirth, and to ascertain the semantics of a yet unborn child and a newborn in natal narratives (mother's stories), and its determining by folklore and mythological traditions.

The most important motifs in the natal narratives discussed below are: a child-fish; a child-mouse; unique abilities and extraordinary mind of a child 
in the mother's womb; special weather outside at the time of delivery; a child choosing the best time to come into this world; a unique child; a baby-the-giant, an ugly child.

\section{THE BABY BEFORE BIRTH}

\section{Animal symbolism of a yet unborn child}

In the natal narrative, a child as the object of a woman's desires and expectations is depicted in a positive way, even idealized. The materials at our disposal show that a woman never blames her child for all the difficulties she had to endure; on the contrary, she always perceives her newborn as a source of joy, her greatest happiness and fulfilment of her dreams. A woman's awareness of her own mission of childbearing as a process of creation opens up her way in search for the highest spiritual value - the very value of an infant to his or her mother, the value our interlocutors have told us about in their stories.

Children in the natal narration manifest themselves firstly in the form of a being that appears in a mother's womb and begins to show certain signs of existence, and then - as a newborn infant. But, before that, they express their presence in a symbolic way, primarily through dreams. For example, seeing a live fish or catching a fish in a dream foretells pregnancy. The universality of this idea, as well as its prevalence, ${ }^{2}$ is very impressive.

That's what my mother told me, and her grandmother, and greatgrandmother ... She said: "This dream was pursuing me ... Constantly the same dream ... The fish is swimming, and the water is clear, and then I ... I am coming up to the water. And as I'm walking, I see fish swimming around. The same dream again and again". ${ }^{3}$

When women talk about the first movements or flutters of a baby in the womb, the motif of fish again sounds in their stories.

The feeling is ... like a fish ... with its tail - splash! ${ }^{4}$

And I had a feeling, you know, like you take a live fish, you know, into your hands, and it moves its tail and turns around, like a splash ... Such feelings... well ... maybe a baby in the water... like a fish... is splashing. ${ }^{5}$

The first movements of the baby are similar to those ... like a little fish is floating inside and tickling. ${ }^{6}$

As scholars argue, fish in dreams is a very typical symbol of an expected baby for all the Slavs (Gura 2009: 505). 
The strong child-fish association can also be found in a wider historical and cultural context, and below are random examples from various traditions. Bronisław Malinowski, describing the system of beliefs about pregnancy on the Trobriand Islands, writes about several taboos pregnant women should observe:

She is also allowed to eat meat and fish, but she must abstain from certain kinds of the latter. The fish which is forbidden to eat are such species as live in the submarine holes of the coral. The natives say that just as it is difficult to haul these fish out of their hiding places, the baby would not easily be brought forth. (Malinowski 1929: 227)

It is also prohibited to eat "fish with sharp, pointed and poisonous fins", otherwise "the child would be ill-tempered and continuously wailing" (ibid.). The Slavs do not advise pregnant women to eat fish for various reasons: the baby would sleep with open eyes, would be dumb, etc. Here Irina Sedakova's statement is worth mentioning: "Symbolic and ontological features of various animals in the context of childbirth are usually transferred to the baby" (Sedakova 2018: 149).

Carl Kerényi, a researcher of ancient mythologies, who worked with Carl Gustav Jung, writes about an early Christian theological discussion at the Court of Sassanides, which tells us about a mother called Hera-Pege-Myria, who was pregnant with a child-god, and carried it in her womb like in the sea. "She has but one fish, it is added - the same that is also called her ship" (Jung \& Kerényi 1971 [1949]: 46).

There is a well-known fairy tale about a queen falling pregnant after eating a fish or a snake. Boris Putilov gives an example of maternal magic in the story "The Serpent Bridegroom": "In order to cure the infertility, it is necessary to weave a special beaded net, throw it into the sea and catch a fish with six wings; take one wing, cook it and give it to the childless Queen, and throw the fish back into the sea" (Putilov 1999: 58).

Some peoples of the world (in Brazil, Mongolia, Venezuela, etc.) have a mythical idea about the fish transformation into the first people or women (Berezkin \& Duvakin n.d.).

In the narratives of Ukrainian women, it is not only a fish that predicts pregnancy, but other living creatures, too: "As for me, my pregnancy was preceded by a dream: I was at home and was warming four or five small storks under a large table lamp." We can assume the connection of this dream motif with the belief that the stork brings babies, widely known among the Slavs (Gura 1997: 659-661) and, in particular, the most intensely recorded in western Polesie and in the lands of the historic Galicia (Halychyna) and the Carpathian region (Vinogradova 1995: 174-175) where our study was conducted. 
Belief, unlike a biographical memoir, outlines a wider range of living creatures that can foreshadow pregnancy: "If you see a calf in your dreams, it means that you might be pregnant"; "when a chicken hatched from an egg in your hands, it means pregnancy and you will soon have a baby."

According to our materials, not only dreams, but also other situations and contexts give signs about a baby to come to the world. We have put down a story from a woman who symbolically links the beginning of her pregnancy to a crane, repeatedly arriving in her yard. ${ }^{10}$ The symbolic proximity of the images of a crane and a stork is observed in the Slavic languages and folk customs (Gura 1997: 646).

In the analysed narratives, besides fish and other animals, the child's first movements are compared with the movements of a mouse: "Well, it's like a mouse waved with its tail"; "11 "You know... it's like a mouse is rustling... slipping"; 12 "It feels like you have a mouse in your belly". ${ }^{13}$

According to the ideas of some inhabitants of the Trobriand Islands, at the beginning of pregnancy a spirit-child or pre-incarnated baby penetrates into a woman's body: "It was simply like the foetus in the womb ... looks like a mouse" (Malinowski 1929: 176-177).

Mice are connected symbolically not only with children, but also with their mothers. In western Ukraine, there is a belief that the belongings of a lady who refuses to help a pregnant woman will be destroyed by mice. Other examples of the mother-mouse association may be found in Belarus: if a peasant going to the field to sow or carrying grain harvest home meets a pregnant woman on his way, the bread will be eaten by mice (Gura 1997: 406). A decoction made by boiling a mouse in the water or milk was given to nursing mothers so they would produce more breast milk (Gura 1997: 403).

As mentioned above, women often compare the first moves of their unborn babies with the movements of various living beings: chicken, worm, duckling, butterflies, etc.

One day I felt that there was something in my tummy that seemed to be a chicken and it moved with its tail, such was the feeling I had... and I realized that it was my baby moving. ${ }^{14}$

The first kick ... the move was as if a worm was slipping. ${ }^{15}$

The first time it moved was like a duckling pecking inside my tummy. ${ }^{16}$

Then, somewhere at the beginning of the fifth month, I began to feel that the child was moving inside ... at first it was like butterflies in the womb. ${ }^{17}$

In the imagination of a mother her baby is associated with a white dove, which she perceives as a heavenly angel. 
And three weeks before I gave birth, my husband went away to Canada for work, and I had to live with my parents. And once we had a fight... well, it was some ordinary domestic conflict, and I ran out into the garden, crying. I felt terrible. And I thought, if it were not for the child, I would live in Ternopil and nobody would humiliate me. [crying] ... And suddenly and unexpectedly in front of my eyes, God knows where it came from, a beautiful white-white dove appeared. It flew and sat on the fence and looked at me with such clever black eyes. And I felt God's grace. I thought it was from Heaven that my yet unborn daughter's guardian angel flew to make me stop thinking such foolish sinful thoughts and to make it clear that my child, like that white snow dove, emm ... due to its purity, innocence, nobility and kindness (well, it's just the way our Nastunia is), will be a great joy and support for me in the future. Thus, having calmed down, I went home and made it up with my parents. ${ }^{18}$

In his Notes about the Southern Rus, Panteleimon Kulish presents the following story illustrating the animal-child symbolism in folk culture:

Once a woman was out in the fields, and a wise woman hid in the corner [of the room] to observe. Suddenly a child crept from a cradle: oh, look! It was not a child, but an old man. Short, with a very long beard! [He] took out the pots from the stove with an oven fork, and began to stodge the meal, groaning. Having done his work, he turned into a child again. When the wise woman started beating him with a broom, he revealed his secret: "I, Granny, have repeatedly transformed, not once and not twice: first I was a fish, then I became a bird, an ant, an animal, and now I have tried to be a human." (Kulish 1856: 34-35)

The animal hypostases of an unborn child are interpreted by Mircea Eliade, who relates similar views to the myths about Mother Earth, which is the mother of all living creatures on Earth. A woman becomes pregnant when souls-children, living inside the Earth, penetrate into her. Thus, according to European beliefs of the nineteenth century, children are brought by aquatic animals (Eliade 1959). Balkan peoples use zoological language code, such as 'sparrow', 'puppy', 'kitty', etc. for the denotation of a not yet christened child, claims Irina Sedakova (Sedakova 2007: 43-44).

Therefore, we can see that the connection of an unborn child with animal hypostases, especially a fish and a mouse, is deeply rooted in the culture of different peoples worldwide and is preserved in the Ukrainian modern oral tradition. In general, the correlation child-animal is a characteristic feature for both traditional and contemporary cultures (Panchenko 2004). 


\section{Child's behaviour in the mother's womb}

One more motif we should pay attention to is how a child shows its presence in the mother's womb. In addition to the first moves, which women compare with the movements of various animals, there are other manifestations of an unborn child that are reflected in the natal narratives.

First of all, women often express surprise at the fact that a "creature" is moving in their belly:

Because a kind of life has appeared in my belly ... and it knocks, rumbles, kicks, moves its hands, feels everything. And I think, when it is born, what will happen next. ${ }^{19}$

It is impossible to describe what it looks like. It's as in the movie "Alien", when something is formed in your tummy and moves with its feet and hands. ${ }^{20}$

For a present-day mother it is natural to compare a boy in the womb with a football player: "It was such an interesting feeling, my baby was moving so much as if a footballer lived in my tummy." ${ }^{\prime 1}$

Most women, when describing their unborn children's first movements, note a special pleasure, emphasizing on the uniqueness of such feelings and the impossibility to experience them in any other way.

It was very interesting when the child started to move. It was such a feeling that someone lives inside of you, that you give somebody life.... it seems it wants to say something to you. ... It's so nice, so it's some kind of an unusual feeling. It cannot be described by words, it only needs to be experienced, and it only needs to be tried. ${ }^{22}$

And I always, when I was on the seventh or the sixth month, when I had already such a tummy, I always loved to put my hands on my tummy, when ... there was nobody near, I put my hands on my tummy, and I talked to my son. ${ }^{23}$

However, in contrast to these idyllic stories, some women point out that it was difficult to endure the very active and sharp movements of the child:

I remember the feeling, but how to describe it? Sasha hit my liver and scratched with his nails. I was told that there could not be such things, but that was really the case. He was born with such a manicure. ... He scratched like a real rat. It hurt so much that I got goose bumps. And they fought like horses, both. I thought that my tummy would break. ${ }^{24}$ 
Such evidence can be taken as a text implementation of the epic motif "Even being in the womb, my child was exceptional", as well as the motif associated with heroic deeds: "During pregnancy I had to endure incredible difficulties".

A child, according to some women's stories, not only "talks" with the help of the language of movements with its parents, but even understands and listens to them:

And our daughter loved when her dad was stroking her. When he put his hand on my tummy, she tried to place herself under his hand. They say that a child feels its family. I think that's true. Always, when Andriy or I touched my tummy, she would always place herself in our hands. It was very nice to understand that she knew her mum and dad. ${ }^{25}$

When my tummy had gotten bigger, and when the child began to move, my husband and I started to read her fairy tales. We had the impression that she was listening... even when we were reading fairy tales, we talked to her and said: 'If you hear us, knock on mum's tummy' - and she knocked and even pressed with her leg or hand, or a finger, which could be seen. ${ }^{26}$

Once it was like a hurricane in my tummy, but when my husband touched it, there was silence at once, as if they knew that with their dad they should be calm... ${ }^{27}$

The next motif, realized in some mothers' stories about their unborn child, is as follows: "Unlike other children, my baby was unique even in my womb; besides, it has already had special abilities and an extraordinary mind":

We even laughed: "Viki should be very smart, because she has already completed a master's degree programme with me". ${ }^{28}$

I became smarter. I came up with such brilliant ideas that I was surprised myself. When I was taking my exams, I asked my baby to help me. I asked him to control my intuition and told him that he was very intelligent. And I passed my exams well. ${ }^{29}$

The baby develops household abilities: "I remember that every week I had to sweep the yard, so I can say that Vasul'ko [her son], even when being in my tummy, helped me to do my housework."30

Your own child, as the narratives manifest, is not only the most intelligent and hardworking, but his or her behaviour is different.

For example, my husband puts my hand on my tummy, and our baby kicks right in the place where his hand was. ... even the leg was visible [smiles] .... he was very fast, as he is now ... here and there ... And when we were 
doing ultrasound, they all said that they had not seen that a child was moving so much inside [laughs]. ${ }^{31}$

The key formula that doctors "have not seen such a baby or quality yet" is often present in the stories of an unusual birth and uncommon behaviour of the infant.

The next motif reveals the idea that a child behaves in the womb regardless of his or her mother's will. All changes in mother's activities, as well as her preferences and tastes, are determined by the wishes of her child.

Well, I had a large foetus ... It was my own fault... Mine and Olezhyk's... fifty-fifty! Because he was a great eater! [laughs] And I was getting up at night to eat meat. ${ }^{32}$

I became very plain, even ugly, face ... [laughs] Yes! ... the face was covered with pigment spots. [to her daughter]: You have probably stolen away my beauty! ... And I always wanted to eat. That's why we have such a gourmet now! $!^{33}$

It was quite an important moment ... When my husband was watching football matches on television I sat with him and watched ... Probably because I was bearing a boy. My husband would say to me in amazement: "But you hate football!" At that time, football became quite an interesting game for $m e{ }^{34}$

The child even determines the time to be born:

Dimochka took his time to be born. I gave birth to him on the forty-first week, not on the fortieth. ${ }^{35}$

Tamila wanted to see the world as soon as possible, she knocked to get out, during the last months it was impossible to withstand pregnancy, she almost wanted to escape... ${ }^{36}$

The child's emotions and feelings can directly master the process of childbirth: "Though I was having a contraction, my uterus did not open, perhaps the baby was afraid..." 37

Here is another motif inherent in the natal narrative: mother's behaviour influences the formation of her future child's character traits. The features a child manifests while in the womb will mould their character:

I was into books when I was pregnant, so you [to her first daughter] are such a bookworm - studied at school very well, graduated from school with honours, study all the time. Nastya, [another daughter]...when I was pregnant with Nastya, I was in motion, so Nastya is such a mobile girl. She likes physical education, sports. She is the first to help about the kitchen, 
likes to cut groceries. Therefore, during pregnancy it is important to take into account your own behaviour, activities, words or even the kind of music you listen to. What you do greatly influences the foetus. It's true. ${ }^{38}$

When I was pregnant with Olya I was dancing almost all the time, till the delivery... at my brother's wedding I was dancing and waltzing around ... and Olya - she loves parties, dancing and singing. But with this oneVitalik - I was nervous, was studying ... thus he is so annoying. ${ }^{39}$

In the traditions of all the Slavs, the period of pregnancy was full of prescriptions, prohibitions, and observations because it was believed that the behaviour of the expecting mother affects the appearance, character, health, and behaviour of the future child both directly and, to a greater extent, also symbolically (Tolstaia 1995: 160-164). In a broader perspective, the abovementioned stories allow us to draw a parallel between the natal narrative and the etiological legend, which, in fact, explains the properties of certain phenomena, objects, and creatures by the peculiarities of their origin (Kachmar 2010). Similarity is seen at the semantic level: even being in the mother's womb, a human possesses certain traits which are revealed after birth and develop into their characteristic features. Actually, such features become apparent because they were formed in the womb.

\section{DELIVERY: WEATHER AND TIME SYMBOLISM IN NARRATING}

The birth of an extraordinary infant - a future god, a hero, the founder of a ruling dynasty - is a well-known and frequent motif in a great number of mythological texts (Campbell 2004 [1949]: 295-308). Unusual or 'magic' infants, according to Ewa Nowina-Sroczyńska, are extraordinary children: they are born in uncommon circumstances and behave differently. In the texts representing various mythological traditions and traditional culture, "the signs of the newborn's superiority were supernatural - as they thought - phenomena that marked their birth" (Nowina-Sroczyńska 1997: 52). Such births are accompanied by storms, earthquakes, and volcanic eruptions.

In the natal narratives of the modern Ukrainian women, the weather outside at the time when a child was born is a common motif.

I remember: I'm lying and looking through the window. Such a strong, heavy rain and wind, the weather was not so good, but I was so happy and it was so easy... easy and so good, it was good..$^{40}$

I was in the maternity ward, and, despite August, it was terribly cold. There was a thunderstorm outside the window. ${ }^{41}$ 
When he was born, it was dull weather ... I wondered: why so? The whole week before, until the ninth of September ... it was warm and sunny, but on that day the weather changed at once: the rain started, the sky was overcast, the wind was blowing. ${ }^{42}$

Other women remember that at the moment of their child's birth, the weather was very good, consonant with their great mood:

Having given birth, I looked through the window. It was a very bright sunny day. And my first feeling was something weird and very, very pleasant. Apparently, I was the happiest person in the world then. ${ }^{43}$

I was lying on the table in the maternity home and looking through the window: it had stopped raining, and I remember golden leaves with droplets of rain sparkle in the sun; the weather was wonderful outside. ${ }^{44}$

Well, I was lying, and it was an extremely beautiful dawn ... it was June, such a beautifully pleasant June morning ... the sun was so nice... such a pleasant morning. ${ }^{45}$

Actually, looking up at the sky during the most significant moments of life is what Mircea Eliade writes about: "The sky remains ever present in the religious life by virtue of its symbolism" (Eliade 1959: 128). According to one woman's story, the weather on her daughter's day of birth influenced all her next birthdays: "My daughter Larisa's birthday always falls on rainy days... Always rainy, you know ... maybe because she was born on a rainy day. ${ }^{346}$

Another narrator connects the girl's cheerful mood with the weather and the time of the day of her birth:

It was a wonderful morning. The delivery was easy ... when I was giving birth, and the rising sun was shining into my eyes. And then I thought that my child would be as joyful and bright as that day was ... And so it is! $!^{47}$

In various Slavic traditions, different weather conditions being observed during delivery acquire a special magical and prognostic status (Kabakova \& Sedakova 2004: 260). We assume that in the modern narratives, these weather observations may take on a similar meaning.

An important motif for the natal narrative is that the time when a baby comes into this world is the best for it. Even today there are beliefs that each child chooses the time of his or her birth: "Well, I do not know ... a child... will be born at the appropriate time." ${ }^{.8}$

Ewa Nowina-Sroczyńska writes that 'holy children' tend to appear at a particular sacred time, especially at midnight or at dawn, or on the day of a great religious feast (Nowina-Sroczyńska 1997). At the same time, it could 
be considered as a cultural universalia that "individual calendars of a woman and her child fit into other calendars - natural and festive - and the points of coincidence or sameness are recorded and marked ... Time of the day, day of the week, season, year, church and family holidays - all these points are extremely important in a prospective and retrospective interpretation of life circumstances" (Sedakova 2011: 183; see also Grushevskii 2006: 48; Shcherbak 2008: 51-52).

In our research materials, some examples of the role of the temporal factors within the framework of the ritual year could be found. A woman whose worldview is oriented to the Ukrainian traditional culture emphasizes that both her children were born on major religious holidays: "My children were both born on big religious holy days. You, Julia, on Pentecost Saturday, and Taras on Easter Monday." 49

In the narratives of these women who are carriers of modern culture, we still find time reference as a significant obstacle:

It's a great time, s-u-u-u-mmer! I want all children to be born in summer, because ... our child was baptized two weeks later and we went outside for a walk with him... for nearly the wh-o-o-ole day. ${ }^{50}$

But I am very happy that my daughter was born in my favourite season, autumn. I really love autumn; I myself was born in November ... for me it is very important. ${ }^{51}$

My Nastya was born at $6 \mathrm{pm}$. The thing that it was not at night ... I was very afraid of giving birth at night. I don't know why. Probably, I was afraid if the doctors could manage ... Maybe I realized that it had already begun. But the very fact of night frightened me. I'm afraid of darkness. ${ }^{52}$

The semiotization of calendar periods in which the child was brought into the world is also characteristic of traditional culture. Thus, Inna Shcherbak writes:

The names of children were associated with the season in which they were born: 'zymak' (from Ukrainian zyma - winter, for a child born in winter), 'osin'chuk' (from Ukrainian osin'- autumn, for a child born in autumn); with a religious fast - 'petrivchenia' (for a child born during St. Peter's fast), the month of the year - 'marchuk' (for a child born in March). (Shcherbak 2008: 57)

Women's extraordinary attention towards the time of their children's birth is a relevant point in such birth stories. One of our interlocutors emphasized the symbolic coincidences of the day of the month and the time when her children were born, whatever question we would ask her regarding children: 
That was the case. Both my children were born on the 15th day of the month. Son at $4 \mathrm{pm}$, and daughter at $4 \mathrm{am} .{ }^{53}$

I had been giving birth for approximately ten minutes. At seven forty-five. Exactly. By the way, [to her child] you were also born at seven forty-five. ${ }^{54}$

For example, my son was born on 3 April, wasn't he? For me, number 3 is a landmark, well, I do not know why ... I was born on the third, but only in September ... so, number 3 inspires me with some kind of confidence, hope, optimism, and this number somehow helps me in my life..$^{55}$

The date and time of a baby's birth in some women's stories undergo symbolization and change into meaningful numbers which have an impact on their child's future fate.

I do not know, it seems to me, because of the fact that I was giving birth on such a great day (it was Easter Friday), on the eve of the most incredible and greatest holiday in the world - Easter, everything was so easy ... And on 13 April, at 14:20, I gave birth to a girl. ... Since my second baby was born on Easter Friday, on the 13th day of the month, I believe that number 13 should bring her only good luck and goodness. ${ }^{56}$

In addition to the daily and calendar birth symbols, it is necessary to mention that in traditional Ukrainian culture the mother was the donor of the fate of her child. The fate is given at the moment of birth, and its good or evil luck depends on the mother (Ivanov 1992 [1991]: 344). The belief that at the moment of birth a baby receives its destiny was widespread among the Hutsuls - an ethnic subgroup of Ukrainians spanning parts of western Ukraine and Romania (Shekerik-Donikiv 1918).

\section{NARRATIVES ABOUT A NEWBORN BABY}

The narratives of Ukrainian women depict the birth of a child as an extraordinary event in a mother's life, and correspondingly the child is unique, not like other children. In part, this motif is realized when a mother tells about her 'not ordinary, unusual' pregnancy, 'not ordinary' childbirth and a child who even in the womb behaves 'in another way'. For each mother, her child has unique abilities; it behaves differently, clearly showing its distinct features. Among contemporary natal narratives, there are memories of a special cry, a special look, a special mind, a special beauty of the baby right after the birth. In this regard, modern narratives about children have something in common with the 
traditional description of fairy-tale's children, which are usually treated as different (Nowina-Sroczyńska 1997).

And you know ... he never cried like any other baby. Children cry, but he simply screamed: 'oh', 'e', 'oh', ' $u$ ', and then 'ma', 'ba'.... Well, he screamed so much that I remember everything. And while he was screaming there, they all stood around him; in short, he was born, and at once gathered the audience around himself. ${ }^{57}$

As she was born, they showed her to me. It seemed to me that I hadn't given birth to a child, but a very nice doll. Sometimes, as you look at someone's baby, you think it is ugly, wrinkled ... And mine, she was such a beauty, the prettiest of all in the whole maternity house. ${ }^{58}$

However, as Ewa Nowina-Srochyńska observes, the most exposed motif for the birth of a 'holy child' is the motif of adult reactions and adult behaviour (Nowina-Sroczyńska 1997: 59). Present-day mothers often say that their newborn babies, unlike other children, looked much older:

On the first day when my husband came in the evening, he took photos of our daughter somewhere eight or nine hours after her birth, and sent the photos to our relatives ... It seemed that it wasn't just a newborn, but a one-week-old baby. ${ }^{59}$

Marichka was plump from the very beginning. She looked like a onemonth-old baby; it wasn't terrible to hold her. ${ }^{60}$

The baby weighed 3,400, and was 51 centimetres tall, but it was very big! A very large head, very broad shoulders, like a three-month-old baby. ${ }^{61}$

The baby was born large: its weight was 4 kilograms, and she was 50 centimetres tall. It was such a big child ... at the age of one week he looked like a baby of a month and a half... It was such a very big, beautiful baby. It seemed as though it was about two months old. ${ }^{62}$

The first meeting of a mother with a premature baby is also described with the motif of special abilities the infant acquires immediately after birth:

There I saw my baby, he was lying under the hood, and then I realized why he was not given to me. There was nobody near him; I came up, he was so pretty, like an angel: his hair was black, his cheeks were small and he clenched his fists and put them under his little head and slept in such a way; he always slept like that, and doctors were surprised that such a small baby knew how to sleep. ${ }^{63}$ 
However, according to our material, the most exposed motif used by mothers when they are telling about their first meeting with the child is the motif of a baby-the-giant.

Vladik ... surely was a giant. In my ward, two women gave birth to girls, they were so thin, so miniature; their mother could take them under the armpit and lie down. And then they brought me my Vladik, he was so... plump cheeks ... and I remember that there were two girls and he was between them, like a knight. ${ }^{64}$

In our opinion, the motif of a baby-the-giant is an example of the direct influence of the heroic epos on the tradition of telling about the birth of a child, which we observe in present-day mothers' stories.

Another frequent storyline shows a baby unattractive at first glance, who then turns out to be handsome, as if a miraculous transformation took place.

Oh, my God, I will tell you honestly, when I saw my first child, I was scared. It was so ugly, blue, and miserable! But when I got her, washed, dressed, swaddled and hugged, when I saw her beautiful hazy eyes, I couldn't believe how pretty she was. ${ }^{65}$

He was so terrible, you cannot imagine. He had such swollen lips... swollen eyes; he looked like my husband when he was drunk. Well, but when I looked at him in the morning, I saw - he was so handsome. ${ }^{66}$

When I looked at my husband, he was standing there in fear, looking at the baby, and then quietly said: "And why is she so ugly? I was even a little hurt. But when our daughter was beautifully dressed, swaddled ... she became like an angel. ${ }^{67}$

A baby was born with such a long head like a squash [laughs]. ${ }^{68}$

Sometimes the motif of an ugly child becomes an impetus for the deployment of a story about maternal fears and emotional experiences.

I remember when Ira was brought for the first time. Our dad had been in Chernobyl, and everyone asked me whether I was afraid to give birth, because the child might be somehow abnormal, with defects. So, Ira was brought ... At that time children were swaddled, not dressed into clothes, as it is now. And my child's face was swaddled very tightly. I looked-all children were as children, and I had a hamster. I was terrified ... I didn't say anything to anyone ... But when the child was brought for the second time I saw that everything was okay, and I calmed down". ${ }^{69}$ 
These ideas can be linked to the traditional Slavic beliefs, which view the infants before christening as not real human beings, but part of the 'other', demonic world (Kabakova 1999: 86). They are regarded as evil spirits, ${ }^{70}$ unclean, ugly, bad (see the list of over 80 pejorative names the Bulgarian call their babies until they are christened in Sedakova 2007: 45-47). These ideas may have some influence on the symbols in the modern natal narratives under discussion.

Another important idea is that of a baby as a gift. Stories about taking a newborn home from the maternity hospital emphasize that a child is a treasure a woman gains after enormous pain and suffering:

My husband came and we went to the room where babies were dressed. It was very nice to see how such a small God's creature was swinging with its little arms and legs ... She was very thin and little. And a midwife gently dressed her into new clothes, bought by her daddy, a hat, an undershirt... My husband bought everything. My daughter's grandmother, my mother, had made a very beautiful blanket slip... ruched, a hat with flowers embroidered all around... she was like an angel. The baby was dressed and wrapped, because she was little and needed the warmth. ... so, she was wrapped and handed to her dad. And she was tied with such a pink ribbon, with a bow ... The happy dad went down the stairs ... descended, and sat in the car. We arrived home ... arrived, and there was nobody at home. Grandmother and grandfather were at work. We arrived home, and at home everything was clean, the flowers ... because everyone was waiting for the baby to arrive. We put the baby into the crib, unwrapped her, and looked at her with admiration. ${ }^{71}$

Some more stories depict an infant as a precious and at the same time a fragile treasure:

We were desperate when Timur was brought to me for the first time, and you cannot believe that it is your child, and you think: "Oh, God, what should I do next?" It is so weak, you are afraid to hold it ... the scene is so moving. ${ }^{72}$

When the nurse left and I needed to dress up Vika, I was so scared; I didn't know how to dress her up. I was afraid lest I should break her arm or leg. And I wondered about how to change her. I asked the nurse, and she said: "Take it, it is your child, change her", and went out. A woman in the ward said: "Tanya, come on, I'll help you" ... She came, and we changed her. ${ }^{73}$

A day later we bathed our baby. After bathing, she slept like a little angel, and I listened to whether she was breathing. ${ }^{74}$ 


\section{CONCLUSION}

The natal narrative depicts a child as an object of a woman's desire and expectation, which is why it is portrayed positively, even idealized. The materials analysed show that a woman never accuses her child of all the difficulties and pains she had to go through; on the contrary, she always perceives her newborn as a source of joy, a gift, her greatest happiness and the fulfilment of her dreams. A child in the natal narrative is shown first of all as a creature that appears in the mother's womb and begins to manifest certain signs of existence, and later as a newborn. Each mother speaks about her child as a unique one, very different from other children. A 'unique' child still being in the womb behaves differently: moves in a special way, shows unusual mind, 'communicates' with parents, etc. The natal narrative realizes the following notion: an unborn child influences its mother: all the changes in her behaviour, preferences, and tastes are determined by the baby.

In the stories about a child in the mother's womb, animal images of a mouse or a fish are often used. The correlation child-animal is well-developed in the texts under analysis and has a symbolical basis deeply rooted in many traditions.

In the modern narratives, the birth of her very child for each mother is an extraordinary event, and her child, unlike other children, is special: a baby is gifted with unique abilities and features that expressly testify to its uniqueness; its behaviour is special even in the womb. The baby is born at a special time, for example, on a religious holiday; it chooses the best season of the year, the best time of the day, rainy or sunny weather. The motif of describing the sky and the weather right after the birth of a child is typical of the natal narrative. A 'unique' baby immediately manifests its exceptional features: loud voice, sensible look, precocious mind, unusual beauty, etc.

The most exposed motif at the birth of a 'unique' child is the motif of adult reactions and adult behaviour. In our opinion, the motif of a baby-the-giant is an example of a direct influence of the heroic epic on the tradition of telling about the birth of one's (own) child, which we trace in today's mothers' stories. One of the cliché expressions that is still used to characterize a newborn boy is "the future head of the collective farm". Such a nomination, although it is an echo of the Soviet era, demonstrates the desire of a woman to distinguish her baby among other newborns, show its strength, physical health, and high social status in the future. Stories about returning home with a child from maternity home emphasize that a child is a precious treasure that a woman gained through pain and suffering.

The main symbols and ways to ascertain values to child's characteristics in the modern narratives under investigation show the parallels with the 
respective elements of the Slavic traditional cultures, the Ukrainian one in the first place, but also beliefs from all over the world. This proves the high potential that the narratives about life events have for studying the symbolic picture of the world of our contemporaries.

\section{NOTES}

1 The data mentioned in the references are presented in the following order: the collector's name and the year of recording; the initials of the narrator; the age of the woman at the time of recording; number of births.

2 A fish has multiple symbolic meanings in the texts of birthlore. In dreams it predicts pregnancy, but for a pregnant woman there are some activities with fish which are considered dangerous for the future baby. Thus the idiom "He is dumb as a fish" is taken literally, and produces restrictions: scaling or gutting and eating fish is considered to be a taboo for pregnant women - the child may be delayed in speech if this prohibition is violated: "You see... Lenka's boy was silent for three years, he did not speak at all, only 'mu-mu', 'liu-liu', 'siu-siu' ... Dimka [her husband] was a fisherman, and on Sundays she scaled and gutted fish... Wherever there is a superstition - follow it!" (Labashchuk: 2016, KAD, 46, two children).

3 Labashchuk: 2008, HOS, 51, three children.

4 Labashchuk: 2009, GP, 39, two children.

5 Labashchuk: 2006, RTV, 35, three children.

6 Rybak: 2008, BHP, 23, one child.

7 Kaftan: 2009, POM, 19, one child.

8 Pitula: 2009, GHI, 62, three children.

9 Vozniuk: 2009, UTS, 34, three children.

${ }^{10}$ Verbovskaia: 2012, XIV, 23, two children.

${ }^{11}$ Labashchuk: 2016, KAD, 46, two children.

${ }^{12}$ Labashchuk: 2009, SAS, 36, two children;

${ }^{13}$ Pitula: 2009, ILG, 39, two children.

${ }^{14}$ Gavronska: 2012, BOV, 42, one child.

${ }^{15}$ Kalinovska: 2012, KMM, 22, one child.

${ }^{16}$ Kharkovets: 2012, KhZhM, 41, two children.

${ }^{17}$ Shandyba: 2012, HLV, 21, one child.

${ }^{18}$ Starko: 2011, SOH, 44, two children. 
${ }^{19}$ Denega: 2011, ROM, 32, two children.

${ }^{20}$ Savchuk: 2011, DMM, 40, three children.

${ }^{21}$ Belaia: 2011, NNT, 23, one child.

${ }^{22}$ Mostova: 2011, TIM, 24, one child.

${ }^{23}$ Vovk: 2011, SUB, 26, one child.

${ }^{24}$ Labashchuk: 2008, PIM, 39, two children.

${ }^{25}$ Loshniv: 2012, SWL, 24, one child.

${ }^{26}$ Soltys: 2011, ROV, 26, one child.

${ }^{27}$ Verbovska: 2012, KIV, 23, two children.

${ }^{28}$ Mostova: 2011, TsIM, 24, one child.

${ }^{29}$ Kalinovska: 2012, KMM, 22, one child.

${ }^{30}$ Babak: 2011, GVI, 28, one child.

${ }^{31}$ Rozvadovska: 2011, ShIV, 21, one child.

${ }^{32}$ Zymnytska: 2011, CAZ, 44, two children.

${ }^{33}$ Starko: 2011, SOG, 44, two children.

${ }^{34}$ Vitiak: 2011, UIV, 23, two children.

${ }^{35}$ Vovk: 2011, NLM, 23, one child.

${ }^{36}$ Mular: 2011, LOB, 41, two children.

${ }^{37}$ Romaniv: 2011, OGP, 46, two children.

${ }^{38}$ Salamandra: 2011, SNB, 39, two children.

${ }^{39}$ Fedirko: 2011, HNM, 46, two children.

${ }^{40}$ Rutka: 2012, ROP, 42, three children.

${ }^{41}$ Starko: 2011, SOG, 44, two children.

${ }^{42}$ Kostetska: 2011, AKV, 23, one child.

${ }^{43}$ Babak: 2011, GVI, 28, one child.

${ }^{44}$ Maidaniuk: 2011, MOA, 37, four children.

${ }^{45}$ Shmilo: 2011, ShHP, 41, two children.

${ }^{46}$ Kolesnik: 2012, VOS, 40, two children.

${ }^{47}$ Starko: 2011, SOG, 44, two children. 
${ }^{48}$ Fedirko: 2011, GNM, 46, two children.

${ }^{49}$ Havryliak: 2012, SOV, 46, two children.

50 Zimnytska: 2011, ZAS, 44, two children.

${ }^{51}$ Krischuk: 2011, SNB, 25, two children.

${ }^{52}$ Loshniv: 2012, ShLW, 24, one child.

${ }^{53}$ Labashchuk: 2012, SSG, 36, two children.

${ }^{54}$ Kohut: 2011, KMI, 46, two children.

${ }^{55}$ Soliak: 2011, ShNL 32, one child.

56 Oliinyk: 2011, OOY, 49, two children.

${ }^{57}$ Labashchuk: 2009, THY, 50, two children.

${ }^{58}$ Novosad: 2012, NMM, 50, three children.

${ }^{59}$ Mostova: 2011, TsIM, 24, one child.

${ }^{60}$ Maksymets: 2011, KMB, 31, two children.

${ }^{61}$ Bachun: 2011, ChTA, 28, two children.

${ }^{62}$ Smakous: 2012, STI, 42, two children.

${ }^{63}$ Holovatiuk: 2012, FIV, 24, one child.

${ }^{64}$ Muliar: 2011, ATO, 27, one child.

${ }^{65}$ Savchuk: 2011, DMM, 40, three children.

${ }^{66}$ Savchuk: 2011, DMM, 40, three children.

${ }^{67}$ Maidaniuk: 2011, MOA, 37, four children.

${ }^{68}$ Dmytryshyn: 2011, DOM, 65, one child.

${ }^{69}$ Kohut: 2011, KMI, 46, two children.

${ }^{70}$ See also an early Western European belief about the souls of children who died unbaptised that would go to hell (Paukštytė-Šaknienè 2020).

${ }^{71}$ Oliinyk: 2011, OSO, 49, two children.

${ }^{72}$ Muliar: 2011, LOB, 41, two children.

${ }^{73}$ Mostova: 2011, TIM, 24, one child.

${ }^{74}$ Shmat: 2011, SHIL, 39, one child. 


\section{REFERENCES}

Atkinson, Robert 1995. The Gift of Stories: Practical and Spiritual Applications of Autobiography, Life Stories, and Personal Mythmaking. Westport, CT \& London: Bergin \& Garvey.

Belousova, Ekaterina 1998. "Nash malysh": sotsializatsiia novorozhdennogo v sovremennoi gorodskoi kul'ture. ["Our Baby": Socialization of a Newborn in Modern Urban Culture.] Zhivaia starina, No. 2, pp. 24-25. Available at https://inslav.ru/sites/ default/files/zhs-1998-2.pdf, last accessed on 7 October 2020.

Belousova, Ekaterina 2003. Rodil'nyi obriad. [Maternity Rite.] In: Aleksandr Belousov \& Inna Veselova \& Sergei Nekliudov (eds.) Sovremennyi gorodskoi fol'klor. Moscow: RGGU, pp. 339-369.

Berezkin, Iurii \& Duvakin, Evgenii n.d. Tematicheskaia klassifikatsiia i raspredelenie fol'klorno-mifologicheskikh motivov po arealam. Analiticheskii katalog. [World Mythology and Folklore: Thematic Classification and Areal Distribution of Motifs. Analytical Catalogue.] Electronic edition. Available at http://www.ruthenia.ru/ folklore/berezkin/e26.html, last accessed on 7 October 2020.

Bird, S. Elizabeth 1994. It's the Talking That's Important: Pregnancy Folklore as Women's Discourse. Women's Studies in Communication, Vol. 17, No. 2, pp. 45-67. https://doi.org/10.1080/07491409.1994.11089782.

Bogdanov, Konstantin 2001. Povsednevnost' i mifologiia: issledovaniia po semiotike fol'klornoi deistvitel'nosti. [Daily Life and Mythology: Studies on the Semiotics of Folklore Reality.] St. Petersburg: Iskusstvo-SPb. Available at https://www. booksite.ru/localtxt/pov/sed/nev/nost/index.htm, last accessed on 7 October 2020.

Boriak, Olena 2001. Z rukopisnikh fondiv IMFE: materiali do "zhinochikh studii' u pol'ovikh zapisakh Liudmili Shevchenko. [From the Manuscript Fonds of the Institute of Fine Arts, Folklore and Ethnology (IMFE) of the National Academy of Sciences of Ukraine: Materials on "Women's Studies" in Liudmila Shevchenko's Field Notes.] Arkhivi Ukraïni, Vol. 1-2, pp. 42-56.

Britsina, Oleksandra 2006. Ukraïns'ka usna traditsiina proza: pitannia tekstologiï ta vikonavstva. [Ukrainian Traditional Oral Prose: Questions on Textology and Performance.] Kyiv: Institut mistetstvoznavstva, fol'kloristiki, ta etnologii.

Budrowska, Bogusława 2000. Macierzyństwo jako punkt zwrotny $w \dot{z} y c i u$ kobiety. [Motherhood as a Turning Point in a Woman's Life.] Wrocław: Wydawnictwo Funna. Available at http://www.isns.uw.edu.pl/pliki/materialy_od_wykladowcow/ gender/Macierzynstwo-jako-punkt-zwrotny.pdf, last accessed on 7 October 2020.

Campbell, Joseph 2004 [1949]. The Hero with a Thousand Faces. Commemorative edition. Princeton \& Oxford: Princeton University Press. Available at http:// www.rosenfels.org/Joseph\%20Campbell\%20-\%20The\%20Hero\%20With\%20A\%20 Thousand\%20Faces,\%20Commemorative\%20Edition\%20\%282004\%29.pdf, last accessed on 7 October 2020.

Cherednikova, Maina 2002. "Golos detstva iz dal'nei dali..." (Igra, magiia, mif v detskoi kul'ture). [“The Voice of Childhood from a Far Distance...” (Play, Magic, and Myth in Children's Culture).] Moscow: Labirint. Available at https://www.booksite.ru/ fulltext/cherednikova/text.pdf, last accessed on 7 October 2020. 
Chubinskii, Pavel 1877. Trudy etnografo-statisticheskoi ekspeditsii v Zapadno-Russkii krai, snariazhennoi Imperatorskim Russkim geograficheskim obshchestvom. Iugo-zapadnyi otdel. [The Works of Ethnographic and Statistical Expedition into Western Russia Lands, Equipped by the Imperial Russian Geographical Society, South-Western Department.] Vol. 4: Obriady: rodiny, krestiny, svad'ba, pokhorony. St. Petersburg: Tipografiia V. Kirshbauma. Available at http://irbisnbuv.gov.ua/ulib/item/UKR0002510, last accessed on 7 October 2020.

Davis-Floyd, Robbie E. 1992. Birth as an American Rite of Passage. Berkeley \& Los Angeles \& London: University of California Press. Available at https://archive. org/details/isbn_9780520084315, last accessed on 7 October 2020.

Dianova, Tatiana 2009. Avtobiograficheskii diskurs i ustnaia fol'klornaia traditsiia: $\mathrm{k}$ metodologii issledovaniia. [Autobiographical Discourse and Oral Folklore Tradition: To the Methodology of Research.] Traditsionnaia kul'tura, No. 4, pp. 4-10. Available at http://www.trad-culture.ru/sites/default/files/files_pdf/ c4e614_e6a222e900cc4e57bb3af88448ed6b98.pdf, last accessed on 7 October 2020.

Eliade, Mircea 1959. The Sacred and the Profane: The Nature of Religion. New York: Harcourt, Inc.

Fine, Elizabeth Calvert 1984. The Folklore Text: From Performance to Print. Bloomington: Indiana University Press.

Florek, Stefan 2007. Genetyczne i środowiskowe determinanty miłości macierzyńskiej. [Genetic and Environmental Determinants of Maternal Love.] In: Bożena PłonkaSyroka (ed.) Miłośc kobiety: Społeczno-kulturowe mechanizmy kreowania emocji. Antropologia mitości, Vol. 1. Wrocław: Arboretum, pp. 27-49.

Gavriliuk, Natalia 1981. Kartografirovanie iavlenii dukhovnoi kul'tury (po materialam rodil'noi obriadnosti ukraintsev). [Mapping of the Phenomena of Spiritual Culture (Based on the Materials of the Maternity Rituals of Ukrainians).] Kyiv: Naukova dumka.

Geertz, Clifford 1973. The Interpretation of Cultures. New York: Basic Books, Inc. Available at https://monoskop.org/images/5/54/Geertz_Clifford_The_Interpretation_of_ Cultures_Selected_Essays.pdf, last accessed on 8 October 2020.

Grinchenko, Gelinada 2007. Usna istoriia: metodichni rekomendatsii $z$ organizatsiï doslidzhennia. [Oral History: Methodological Recommendations for Research Organization.] Kharkiv: Kharkivs'kii natsional'nii universitet imeni V.N. Karazina. Available at http://oralhistory.com.ua/assets/images/img_pubpraktikum/Metodyka_1_Grinchenko.PDF, last accessed on 8 October 2020.

Grushevskii, Marko 2006. Ditina u zvichaiakh i viruvanniakh ukraïns'kogo narodu. [Child in the Customs and Beliefs of the Ukrainian People.] Kyiv: Libid'. Available at http://chtyvo.org.ua/authors/Hrushevskyi_Marko/Dytyna_u_zvychayah_i_ viruvanniah_ukrainskoho_narodu/, last accessed on 8 October 2020.

Grushevskii, Marko (comp.) 1906. Ditina v zvichaiakh i viruvanniakh ukraïns'kogo narodu. Materiali z poludnevoi Kï̈vshchini. [Child in the Customs and Beliefs of the Ukrainian People. Materials from the Southern Kyiv Region.] Materiali do ukraïns'ko-rus'koï etnologiï, Vol. 8. Available at http://irbis-nbuv.gov.ua/ulib/ item/UKR0001197, last accessed on 8 October 2020.

Grushevskii, Marko (comp.) 1907. Ditina v zvichaiakh i viruvanniakh ukraïns'kogo narodu. Materiali z poludnevoï Kï̈vshchini. [Child in the Customs and Beliefs 
of the Ukrainian People. Materials from the Southern Kyiv Region.] Materiali do ukraïns'ko-rus'koï etnologiï, Vol. 9. Available at http://irbis-nbuv.gov.ua/ulib/ item/UKR0001202, last accessed on 8 October 2020.

Gura, Aleksandr 1997. Simvolika zhivotnykh v slavianskoi narodnoi kul'ture. [Symbolism of Animals in the Slavic Folk Culture.] Moscow: Indrik. Available at https:// inslav.ru/publication/gura-v-simvolika-zhivotnyh-v-slavyanskoy-narodnoytradicii-m-1997, last accessed on 8 October 2020.

Gura, Aleksandr 2009. Ryba. [Fish.] In: Nikita Tolstoi (ed.) Slavianskie drevnosti: etnolingvisticheskii slovar', Vol. 4. Moscow: Mezhdunarodnye otnosheniia, pp. 505-506.

Gvozdevich, Stephania 1997. Rodil'na obriadovist' ukrantsiv. [Maternity Rituals of the Ukrainians.] Narodoznavchi zoshiti, No. 2, pp. 111-122. Available at https:// archive.org/stream/zoshyty/\%D0\%9D\%D0\%B0\%D1\%80\%D0\%BE\%D0\%B4\%D 0\%BE\%D0\%B7\%D0\%BD\%D0\%B0\%D0\%B2\%D1\%87\%D1\%96\%20\%D0\%B7\%D 0\%BE\%D1\%88\%D0\%B8\%D1\%82\%D0\%B8\%201997\%202\#page/n49/mode/2up, last accessed on 8 October 2020.

Iashchurzhinskii, Hrisanf 1893. Pover'ia i obriadnosti rodin i krestin. [Birth and Christening Beliefs and Rituals.] Kievskaia starina, Vol. 42, pp. 74-83. Available at https://runivers.ru/bookreader/book479609/\#page/78/mode/1up, last accessed on 8 October 2020.

Ivanov, Petr 1992 [1991]. Narodnye rasskazy o dole. [Folk Stories about Fate.] In: Anatolii Ponomariov \& Tamara Kosmina \& Olena Boriak (eds.) Ukraïntsi: narodni viruvannia, povir’ia, demonologiia. 2nd ed. Kyiv: Libid', pp. 342-374. Available at http://irbis-nbuv.gov.ua/ulib/item/UKR0001994, last accessed on 8 October 2020.

Jung, Carl Gustav \& Kerényi, Carl 1971 [1949]. Essays on a Science of Mythology: The Myth of the Divine Child and the Mysteries of Eleusis. Revised edition. Princeton, N.J.: Princeton University Press.

Kabakova, Galina 1999. Deti nekreshchenye. [Unbaptized Children.] In: Nikita Tolstoi (ed.) Slavianskie dreunosti: etnolingvisticheskii slovar', Vol. 2. Moscow: Mezhdunarodnye otnosheniia, pp. 86-88. Available at https://vk.com/wall112143772_8486, last accessed on 8 October 2020.

Kabakova, Galina \& Sedakova, Irina 2004. Mladenets. [Infant.] In: Nikita Tolstoi (ed.) Slavianskie drevnosti: etnolingvisticheskii slovar', Vol. 3. Moscow: Mezhdunarodnye otnosheniia, pp. 257-264. Available at https://vk.com/wall-112143772_8486, last accessed on 8 October 2020.

Kachmar, Mariia 2010. Ukraïns'ka etiologichna legenda na storinkakh chasopisu "Zhite i slovo". [Ukrainian Etiological Legend on the Pages of "The Life and the Word" Periodical.] Ukraïns'ke literaturoznavstvo, No. 72, pp. 218-226. Available at http:// institutes.lnu.edu.ua/franko/wp-content/uploads/sites/7/ukr-literaturoznavstvo/ 72_2010/72_2010_m.kachmar.pdf, last accessed on 8 October 2020.

Kaindl, Raimund Fridrikh 2000. Gutsuli: ïkh zhittia, zvichaï ta narodni perekazi. [The Hutsuls: Their Life, Customs, and Folk Stories.] Chernivtsi: Molodii bukovinets'. Available at https://chtyvo.org.ua/authors/Kaindl_Raimund_Fridrikh/Hutsuly_ ikh_zhyttia_zvychai_ta_narodni_perekazy/, last accessed on 8 October 2020.

Kirshenblatt-Gimblett, Barbara 1989. Authoring Lives. Journal of Folklore Research, Vol. 26, No. 2, pp. 123-149. Available at http://www.jstor.org/stable/3814238, last accessed on 8 October 2020. 
Kravchenko, Vasil 1928. Zhittia rodinne v s. Bekhakh. Vesillia. Narodzhenets'. Vmirannia. [Family Life in the Village of Bekhi. Marriage. Childbirth. Dying.] Archive of the Institute of Art History, Folklore and Ethnology named after M. T. Ryl'skii of the National Academy of Sciences of Ukraine, fund 15, storage unit 158. Manuscript. Krugliakova, Tatiana 2001. Byt i fol'klor dorodovogo otdeleniia. [Life and Folklore of the Prenatal Service Department.] In: Sergei Nekliudov (ed.) Rodiny, deti, povitukhi $v$ traditsiiakh narodnoi kul'tury. Moscow: Rossiiskii gosudarstvennyi gumanitarnyi universitet, pp. 217-235. Available at https://www.booksite.ru/fulltext/ rodiny/text.pdf, last accessed on 8 October 2020.

Kulish, Panteleimon 1856. Zapiski o Iuzhnoi Rusi. [Notes about the Southern Rus'.] Vol. II. St. Petersburg: Tipografiia Aleksandra Iakobsona. Available at https:// cutt.ly/2rtVqOd, last accessed on 8 October 2020.

Malinka, Aleksandr 1898. Rodyny i khrestyny (material sobran v m. Mrin Nezhinskogo uezda). [Childbirth and Christening (Materials Collected in the Town of Mrin, Niezhyn County.] Kievskaia starina, Year 17, Vol. 61, pp. 254-286. Available at https://runivers.ru/bookreader/book479882/\#page/300/mode/1up, last accessed on 8 October 2020.

Malinowski, Bronislaw 1929. The Sexual Life of Savages in North-Western Melanesia: An Ethnographic Account of Courtship, Marriage, and Family Life among the Natives of the Trobriand Islands, British New Guinea. New York: Eugenics Pub. Co. Available at https://archive.org/details/sexuallifeofsava00mali/page/n3/mode/2up, last accessed on 8 October 2020.

Marander-Eklund, Lena 2000. Berättelser om barnafödande. Form, innehåll och betydelse $i$ kvinnors muntliga skildring av födsel. [Narratives of Childbirth: The Form, Content and Meaning in Women's Oral Depiction of Birth.] Diss. (PhD Thesis). Turku: Åbo Akademis förlag.

Marander-Eklund, Lena 2020. The Birth of a Child as Experienced and Narrated in 1990s Finland. Folklore: Electronic Journal of Folklore, Vol. 80, pp. 125-150. https://doi.org/10.7592/FEJF2020.80.marander_eklund.

Miller, Tina 2005. Making Sense of Motherhood: A Narrative Approach. Cambridge: Cambridge University Press. https://doi.org/10.1017/CBO9780511489501.

Mushinka, Mykola 1961. Narodzhennia ditini u zvichaiakh sela Kuriv Bardiïvs'kogo okrugu. [Childbirth Rites in the Village of Kuriv, Bardyiv District.] Duklia, No. 2, pp. 107-114.

Nowina-Sroczyńska, Ewa 1997. Przezroczyste ramiona ojca: Studium etnologiczne o magicznych dzieciach. [Father's Transparent Arms: Ethnological Study on Magical Children.] Łódź: Wydawnictwo Universytetu Łódźkiego.

Onishchuk, Antin 1912. Z narodn'ogo zhitia Gutsuliv. Rodini i khrestini, ta ditina do shostogo roku zhittia. [Childbirth, Cristening and Child until Six.] Materiiali do ukraïns'koï etnol'ogï, Vol. 15, pp. 90-113. Available at https://www.twirpx.com/ file/2155029/, last accessed on 8 October 2020.

Oring, Elliott 1987. Generating Lives: The Construction of an Autobiography. Journal of Folklore Research, Vol. 24, No. 3, pp. 241-262. Available at http://www.jstor. org/stable/3814333, last accessed on 8 October 2020.

Orszulak-Dudkowska, Katarzyna 2008. Ogtoszenie matrymonialne: Studium z pogranicza folklorystyki i antropologii kultury. [Matrimonial Advertisement: A Study from the 
Borderline of Folklore and Cultural Anthropology.] Łódzkie studia etnograficzne, Vol. XLVII. Łódz: Polskie towarzystwo ludoznawcze.

Orshuliak-Dudkovska, Katazhina 2010. Smaki mogo domu: Pamiat' - mif - naratsiia. [The Tastes of My Home: Memory - Myth - Narrative.] Studia methodologica, Vol. 30, pp. 49-54. Available at https://www.academia.edu/2450947/Studia methodologica_30, last accessed on 6 October 2020.

Panchenko, Aleksandr 2004. Otnoshenie k detiam v russkoi traditsionnoi kul'ture. [Attitude towards Children in Russian Traditional Culture.] Otechestvennye zapiski, No. 3, pp. 18-28. Available at https://magazines.gorky.media/oz/2004/3/ otnoshenie-k-detyam-v-russkoj-tradiczionnoj-kulture.html, last accessed on 8 October 2020.

Paukštytė-Šaknienè, Rasa 2020. Cycle of Birth Customs in Lithuania: Structural and Social Changes in Contemporary Society. Folklore: Electronic Journal of Folklore, Vol. 80, pp. 11-34. https://doi.org/10.7592/FEJF2020.80.paukstyte_sakniene.

Putilov, Boris 1999. Ekskursy v teoriiu $i$ istoriiu slavianskogo eposa. [Excursus into the Theory and History of the Slavic Epos.] St. Petersburg: Peterburgskoe vostokovedenie. Available at https://www.booksite.ru/fulltext/epos/text.pdf, last accessed on 9 October 2020.

Razumova, Irina 2000. Potaennoe znanie sovremennoi russkoi semi: Byt. Fol'klor. Istoriia. [Secret Knowledge of the Modern Russian Family: Everyday Life, Folklore, History.] Moscow: Indrik.

Rich, Adrienne 1976. Of Woman Born: Motherhood as Experience and Institution. New York \& London: W. W. Norton \& Co. Available at https://ru.scribd.com/ doc/242774285/Rich-Adrienne-Of-woman-born-Motherhood-as-experience-andinstitution-pdf, last accessed on 8 October 2020.

Sedakova, Irina 2007. Balkanskie motivy v iazyke i kul'ture bolgar. Rodinnyi tekst. [Balkan Motifs in Bulgarian Language and Culture: Birthlore.] Moscow: Indrik. Available at https://inslav.ru/publication/sedakova-i-balkanskie-motivy-v-yazykei-kulture-bolgar-rodinnyy-tekst-m-2007, last accessed on 8 October 2020.

Sedakova, Irina 2011. Kategoriia vremeni v slavianskom "tekste rozhdeniia": zachatie i beremennost'. [Category of Time in the Slavic "Text of Birth": Conception and Pregnancy.] In: Svetlana Tolstaia (ed.) Prostranstvo i vremia v iazyke i kul'ture. Moscow: Indrik, pp. 181-197. Available at https://inslav.ru/sites/default/files/ editions/2011_prostranstvo_i_vremja.pdf, last accessed on 8 October 2020.

Sedakova, Irina 2018. Bolgarskie predstavleniia o homo perfectus (Na materiale rodil'noi obriadnosti). [Bulgarian Views on Homo Perfectus (On the Data of Childbirth).] In: Svetlana Tolstaia (ed.) Obraz cheloveka v iazyke i kul'ture. Moscow: Indrik, pp. 144-160. DOI: 10.31168/2619-0834.2018.7.

Shchepanskaia, Tatiana 1999. Mifologiia sotsial'nykh institutov: rodovspomozhenie. [The Mythology of Social Institutions: Delivery Care.] In: Konstantin Bogdanov \& Aleksandr Panchenko (comps.) Mifologiia i povsednevnost': materialy nauchnoi konferentsii (Sankt-Peterburg, 24-26 fevralia 1999 goda). Vol. 3, pp. 389-423. Available at http://www.poehaly.narod.ru/repr-1.htm, last accessed on 8 October 2020.

Shcherbak, Inna 2008. Diti u narodnii terminologiï: leksika i simvolika. [Children in Folk Terminology: Vocabulary and Symbols.] In: Marina Grimich (ed.) Narodna 
kul'tura ukraïntsiv: zhittevii tsikl liudini: istoriko-etnografichne doslidzhennia. Vol. 1. Diti, ditinstvo. Ditiacha subkul'tura. Kyiv: Dulibi, pp. 50-59.

Shekerik-Donikiv, Petro 1918. Rodini i khrestini na Gutsul'shchini (v s. Golovakh i Krasnoïli Kosivs'kogo povitu). [Childbirth and Christening in Hutsul Region (in the Villages of Holovakh and Krasnoily, Kosiv District.] Materiali do ukrä̈ns'korus'koï etnologiï, Vol. XVIII, pp. 86-122.

Simonides, Dorota 1973. Współczesne podanie wierzeniowe. [Contemporary Belief Application.] Lud, Vol. 57, pp. 95-109.

Thurer, Shari L. 1994. Myths of Motherhood: How Culture Reinvents the Good Mother. New York: Penguin Books.

Titon, Jeff Todd 1980. The Life Story. The Journal of American Folklore, Vol. 93, No. 369, pp. 276-292. DOI: 10.2307/540572.

Tolstaia, Svetlana 1995. Beremennost', beremennaia zhenshchina. [Pregnancy, Pregnant Woman.] In: Nikita Tolstoi (ed.) Slavianskie drevnosti: etnolingvisticheskii slovar'. Vol. 1. Moscow: Mezhdunarodnye otnosheniia, pp. 160-164. Available at https:// vk.com/wall-112143772_8486, last accessed on 9 October 2020.

Vinogradova, Liudmila 1995. Otkuda deti berutsia? Polesskie formuly o proiskhozhdenii detei. [Where Do Children Come From? Formulas about the Origin of Children from the Region of Polesie.] In: Nikita Tolstoi (ed.) Slavianskii i balkanskii fol'klor: etnolingvisticheskoe izuchenie Poles'ia. Moscow: Indrik, pp. 173-187. Available at https://inslav.ru/images/stories/pdf/SBF-1995.pdf, last accessed on 9 October 2020.

Zielińska, Magdalena 2007. Postawy kobiet wobec macierzyństwa. [Women's Attitudes towards Motherhood.] In: Bożena Płonka-Syroka (ed.) Mitośc kobiety: Spotecznokulturowe mechanizmy kreowania emocji. Antropologia miłości. Vol. 1. Wrocław: Arboretum, pp. 49-67.

Oksana Labashchuk is Professor (PhD) at the Department of Theory and Methods of the Ukrainian and World Literature at Ternopil Volodymyr Hnatiuk National Pedagogical University, Ukraine. Her main research areas are anthropology and narratology studies, folk beliefs and narratives, folklore.

lov081168@tnpu.edu.ua

Halyna Derkach is Assistant Professor ( $\mathrm{PhD}$ ) at the Department of Foreign Languages at Ternopil Volodymyr Hnatiuk National Pedagogical University, Ukraine. Her latest research deals with comparative studies, anthropology and narratology studies, folklore.

halder@tnpu.edu.ua

Tetiana Reshetukha is Assistant Professor (PhD) at the Department of Journalism at Ternopil Volodymyr Hnatiuk National Pedagogical University, Ukraine. Her latest research deals with social communications, anthropology and narratology studies, folklore.

reshtetyana@tnpu.edu.ua 


\title{
"HOW I GAVE BIRTH" (AND WHY I AM WRITING ABOUT IT): WOMEN'S NARRATIVES OF FIRST CHILDBIRTH EXPERIENCES FROM INTERNET PUBLICATIONS
}

\author{
Natalia Gramatchikova \\ Senior Research Fellow \\ Center of History of Literature, Institute of History and Archeology \\ Ural Branch of the Russian Academy of Sciences, Russia \\ n.gramatchikova@gmail.com
}

\begin{abstract}
This article is dedicated to the research of the structures and meaningful concepts of women's stories about the first childbirth, obtained by their personal experience in the governmental obstetrical system. Narratives of childbirth contain complex knowledge including description of physiological and emotional reactions and characteristics of Russian maternal initiation practices, culminating in the maternity ward. Similar narratives posted on social network and web pages of family portals reveal elements of hypertext and several leading factors of their origin, such as being the consolidation of a new identity through a retrospective autobiographical story, joining the community of motherhood, broadcasting experience to its new members, etc.
\end{abstract}

Keywords: childbirth, family, maternity hospital, narrative, pain, personal history, repressiveness, women in labor

\section{INTRODUCTION}

The first draft of this research, presented as a lecture in Moscow at the 3rd National Russian Congress of Folklore in 2014, received a critical response unexpected for the author. The criticism partially referred to the selection of material and the author's approach to it. Other replies repudiated the very interpretation of narratives on childbirth as a story of the existing discriminating practices, referring them to the irrelevant Soviet past. Meanwhile, the recent (at that time) empirical repeated experience of the author (who has had four children through caesarean section) as well as the collected first-hand materials witnessed of the inverse. 
In Russia, for a couple of past decades, research on motherhood and childhood has developed in several different directions. Folklorists, ethnographers and ethnolinguists collected and processed field materials on the transformation of traditional birth rites, which remains beyond the scope of this article. Anthropologists, sociologists, and historians formed an interdisciplinary field of research in the context of humanization of medicine and bioethics. Gender and feminist studies have driven this 'new wave' of the anthropology of motherhood development. The bibliography of such studies includes hundreds of Russian-language publications. However, this amount continues to lag behind its foreign counterparts.

The popularity of works such as Birth in Four Cultures by Brigitte Jordan (1978) and Human Birth: An Evolutionary Perspective (Foundations of Human Behavior) by Wenda R. Trevathan (1987) showed signs of understanding the necessity to humanize birth and to pay attention to the emotional condition of women in labor. The first collection of articles devoted to pregnancy and births, seen from an intercultural point of view, Anthropology of Human Birth, edited by Margarita A. Kay (1982), and Ethnography of Fertility and Birth, edited by Carol P. MacCormack (1982) were based on the approach suggested by Jordan. ${ }^{1}$ Similar Russian studies developed with some delay due to a different social and academic context. There were a few works on childbirth written by folklorists and anthropologists in the 1990s, while the thesis of birth ritualism preservation in the state establishments sounded as a forward-looking one (Belousova 1999). However, in the past 15 years, Russian studies of the obstetrical system, motherhood and childhood were carried out by researchers of virtually all disciplines of the humanities and social sciences. Feminist values are actualized in these studies.

Folklorists indicate that current childbirth rites show signs of transformation in female knowledge and behaviors, characteristic of peasant and metropolitan culture (Shchepanskaia 1999; Nekliudov 2001; Olson \& Adonyeva 2012). Historians study material related to motherhood, pregnancy, etc., based on the data of various social strata of different epochs (Mukhina \& Pushkareva 2012; Pushkareva \& Mitsiuk 2015; Mitsiuk \& Pokusaeva 2016). Sociologists were among the first researchers to record the problem of a trust gap, publishing a collection of articles in 2009, under the heading Health and Trust: A Gender Approach to Reproductive Medicine (Zdravomyslova \& Temkina 2009), including works by researchers who continue to study these issues (Elena Zdravomyslova, Anna Temkina, Olga Brednikova, Ekaterina Borozdina, Olga Tkach, etc.). Voluminous works on obstetric aggression are in high demand not only among the researchers but also among the professional medical community (Mikhel' 2017; Radzinski 2017). ${ }^{2}$ 
A survey of Russian and foreign sources that covers the topic of obstetrics and childbirth has become the topic of several historiographical articles that demonstrate the rapidly accumulating package of research (Nartova 2016; Pushkareva \& Mitsiuk 2017; Kuksa 2019).

The greater part of the aforementioned studies used archival data, interviews, and ego-documents as their foundational materials. However, in the past two decades women began to express their labor experiences in a new way, through posts on the social media, forums, and blogs. This new type of expression has created new research frames. Thus, the narrative study of the structures and objectives of the female childbirth stories, derived from sites and forums offering a space for the exchange of personal experiences on the subject, proves to be a valuable philological task (Raynor 2005), especially considering the fact that the Russian-language sector of the Internet has yet to be properly examined.

\section{MATERIAL AND PROBLEMS OF INVESTIGATION}

A woman can never be fully prepared for childbirth. Birth, like death, can encroach unexpectedly. During childbirth, a woman teeters on the boundary between life and death, only to return with the title of Mother. Although only the first birth is socially complaisant, it is precisely the first birth that affirms the new stage of family life and transforms partners into parents, in accordance with relatives' expectations.

The first birth is normative for the obstetrical system, revealing the condition of the perinatal culture, and it is important for the examination of alternative childbirth methods (birth in water, at home, etc.). A complete picture of a present-day birth can only be attained by analyzing all birth methods, including through the socialized medical system, at a private paid clinic, at home, by caesarean section, second and further births, as well as childbirth with complications. However, the first childbirth experience is the litmus test for the condition of the obstetrical system, since it occurs without the woman seeking an option of particular comfort or safety.

The source of the material collected for analysis was Russian-speaking women writing about their first personal childbirth experiences in the governmental obstetrical system, on internet sites and forums devoted to motherhood and childbirth. The greater portion of texts I obtained for the analysis were collected from the websites 7ya.ru, Дети@Mail.ru, and Kid.ru as well as the VK.com social network (the group Stories of childbirth. How I gave birth. Birth of my child). The list of sites is extensive, but texts analyzed for my purposes 
are definitively illustrative. ${ }^{3}$ The timeframe covers the last 20 years, since some texts were written with considerable time lags, because often the author's decision to speak about her first birth was a direct result of the experience of the second and further births.

Using these materials, I focused on the following questions:

1) What is the structure of the narrative initiated by the woman herself and not by the interviewer?

2) What is the narrator's position in these posts? In what manner does the woman's position enter into the medical prenatal system? How does she evaluate the system and how does she communicate this evaluation to the community? What moments of her childbirth experience are reflected as traumatic?

3) What are the objectives and meanings found in the messages in internet texts? Are these messages caused by the desire to remember and share experiences? Are they meant for cheering up, warning or scaring? What enquiries of the audience do these messages answer?

\section{INTERNET NARRATIVES OF CHILDBIRTH: GENERAL REMARKS}

Internet narratives differ from those obtained by interviewing, performing the function of autobiographical communication and horizontal translation of experience. Verbal communication is highly significant in Russian culture in general and, as a result, also valued in current birth rituals (see also Belousova 1999), causing us to pay particular attention to these aspects in such stories.

It is difficult to impose typology on these narratives because of differences in such factors as education, health, financial status, social status, places of residence, proximity of spouse and other close relatives and their relationships as well as the level of skills and professionalism of medical workers. Nevertheless, from the philological point of view, narratives of childbirth often contain features peculiar to supertexts (Toporov 1995 [1971]: 275) because they contain uniform structural parts, created in the general narrative model (which is connected to physiological stages of birth and to realities of birth aid in maternity wards). A certain genre model was assimilated while reading similar stories, but before posting their own. "I have read a lot of stories about childbirth and thought that when it finally happens to me, I will write about my experience..." (Marchenkova n.d.). On the other hand, narratives are often formed in an oral manner, then later posted on the Internet. 
Why did I write about this? Because I have an acquaintance who wants to have a baby, but she's afraid. She asked me to tell her how it was with me. After our talk, I had the idea to share my story with others. (Nastia 2019)

Characteristic of these types of narratives is the high concentration of numbers included: the expected delivery date, the time the contractions begin, their length and how often they occur, measurement of dilation of the cervix, what time the water breaks, and how long is the time between water breaking and birth, length of the labor, weight and length of the newborn, and even the number of doctors in the delivery room ("There were a total of seven medical workers plus Nadia and me. That had to mean something" (bjbj2 n.d.)), etc. The condition of consciousness changes time perception: a slow-motion effect exists during the labor and for some time after birth: "So ten days ago today, my son came into this world" (Marchenkova n.d.); a few hours of contractions seems comparable to weeks of pregnancy: "A 42-week pregnancy and birthing in ten hours" (Evgeniia 2012).

However, colors and smells are not fixated as clearly in the memories (with the exception of the memory of a milk-like smell of the newborn or a long-term complex negative feeling: “...The pain is making me sick to my stomach. With every contraction, I was with my 'white friend' (by the way, to make matters worse, it was broken and stunk all night)" (Mashinova 2020)); and tactile feelings are most often expressed as painful. The level of acuity of words and actions and not only their own words, but those of their roommates, of the doctors and midwives, etc., is very high. ${ }^{4}$

For the most part, the internet audiences of childbirth narratives are female, usually cooperative with the medical system. Their firsthand experiences demonstrate that the governmental obstetric system is most loyal to women who "do everything correctly": register the pregnancy in a timely manner, are young, married, with a desire to give birth at the maternity hospital and are open to the recommendations and actions of the medical personnel there.

Most of the authors of the narratives consider their first birth positive and favorable overall; the titles of their stories reveal that in retrospect, they often accentuate the humorous side of their personal story. It is worthwhile to note that the narratives we studied do not in any manner claim to cover the full extent of childbirth stories. Rather, they are selections demonstrating our basic premise (considering it would be impossible to reproduce the population while overlooking the well-being of the first-time mother's birthing experience). Close concomitants in the material I consider here are stories of aggression and abuse during childbirth, medical neglect, stillborn cases, etc. The boundary between the 'good' and 'bad' is rather fluid, and in every story, topics of (dis)trust and 
aggression emerge, though they are not always acknowledged by the narrators themselves.

\section{THE MAIN NARRATIVE ELEMENTS}

Next, the parts of the childbirth narrative and their semantic content are considered. Highlighting the successive elements of the narrative structure associated with the physiological stages of delivery and logistics of the maternity hospital, particularly important themes occurring within each department related to that stage of childbirth (the emergency room, the labor and delivery room, etc.) are discussed. Reference points of the childbirth story are so tenacious that, even if the mother did not have a particular experience, they will still note their absence typically with relief, since the marker was a connection to unpleasant aspects of childbirth:

For ten years, I listened to other people's stories about childbirth. ... Each story was worse than the one before it ... But I still wanted a baby so bad, and I was ready to be the hero... when my long-awaited baby began to form within me, my fears also grew ... I'll die from unbearable pain during labor ... the rude nurse will ignore my suffering without even a drop of sympathy ... I will be torn during delivery ... my newborn will be dropped on the cement floor. (Elena 2007)

\section{Introduction: An unexpected inception}

The introduction to the story of childbirth is often a brief narrative about how the pregnancy went. The beginning of this birthing process is almost always described as unexpected. Everything that happened immediately before the onset of labor is imprinted in the memory as the last moments of peaceful life with its coziness, comfort, and tastes: many women remember what they ate just before the start of childbirth: bread with milk, apple and plum pie; ice cream, nuts, peaches, cherries.

Here, the qualities that a woman demonstrates in her normal status and social environment are important. Rational reasoning and planning can be positioned as leading features, and this style will project throughout the narrative from pregnancy to childbirth: "I'm used to planning important events in my life. And child planning was no exception ... I never wanted surprises, especially during pregnancy" (Matiz 2015). ${ }^{5}$ In the concept of labor, the woman 
in the analyzed texts is active, she has a respected status in the family, including among relatives of the older generation: "My mother-in-law was really worried about me and talked me into staying at home so that labor didn't start outside, but I went everywhere with my husband, walked in the evening" (Marina 2008). "I started to shout out commands. I'm in labor, take me to the hospital..." (Marchenkova n.d.).

The broader context, in which the date of birth was included in the preparatory period, literally collapses at the onset of labor: "April 20th... It's Hitler's birthday... I wanted to give birth already" (Calypso 2010). The comic relief contained in this message makes it clear to the audience how the measurement of time and the idea of good days vary for a woman tired of waiting.

\section{Emergency department of the maternity hospital:}

\section{Entrance to the 'other world'}

The initial part of the stories about childbirth, as a rule, contains internally opposed episodes: the inevitable bustle of arriving to the emergency room and being admitted to the maternity hospital. No matter what titles the expectant mother has taken on heretofore ('the planner', 'the organizer of the nest' and even 'the silly friend'), she makes the decision that it is time to go, and communicates this decision to the family, thus maintaining an accentuated subjectivity. However, even when admitted to the maternity hospital, a woman's activity is threatened in the face of strict rules in which the 'necessary' and 'required', including personal belongings, are determined by the medical staff.

From the moment of the woman's admittance to the maternity ward, her narrative expresses the framework of a journey to the 'other world'6, with features similar to a travelogue guide. The following scheme is well-known: farewell to your spouse (or any other person who came with you) - enema - shower - official clothes. The narrative marker of this new world is the maternity gown ("They put an UGLY gown on me ... and gave me an ugly robe too (of course, I'm not worried about THAT, but it just wasn't possible not to mention IT" (Jane 2006)), shaving ("Hungry, scared, took off my clothes and took a shower. The water wasn't hot enough, a hunk of household soap, a blunt razor..." (Zlato-serebro 2009)), and an enema ("I never remember in my whole life I had an enema, and I came out of the toilet with the feeling that the worst is behind me" (Olga 2001)). Even just one familiar person on the staff has the potential to change the woman's perspective immensely. 
They gave me a shirt to change into, put in the enema, and sent me to wash off in the shower. I love showers, even while in labor - even washed my hair while I was in there - for that I got a lecture from the nurse. Went to my room - where my friend, Nadiusha was happy to see me, maybe this won't be so bad. (bjbj2 n.d.)

Each of these three elements - the gown, shaving, and the enema, are connected to the loss of the status, reducing the expectant mother to the lowest rank in societal hierarchy with the loss of property and even gender and age attributes (with the act of shaving). Nevertheless, most narrators are simply mundane about these procedures: "Asked me if I agreed to an enema. Sure. It wasn't as awful as I thought it would be...." (Shepka n.d.), but often this attitude is paid for by a contrasting difficult experience:

The doctor put his finger up my uterus. I let out a scream in pain not expecting it. Doctor says, how do you expect to give birth? Changed into the maternity gown. Enema. I was worried about it, but it wasn't as bad as I thought it would be. (Elisaveta777 2015)

Let us note the obvious associative connections and meanings that are embedded in these three things, because they are actualized in the narratives. The maternity gown, especially since birth and death are deeply related to each other, can be considered as the antithesis of mortal clothing. The clothing of the deceased has to be clean, new, and belong to them; in contrast, the typical maternity gown is used, foreign, and, although sterile, visually impure. The impression of the gown is further aggregated when given menstrual pads made from rags (Olga 2001). Shaving of the genitals and having an enema are the first formidable threats of the liminal state, destroying intimacy and producing shame. The procedure for setting up an enema during contractions is painful and is reflected narratively with a lack of trust. Many women make attempts to avoid the procedure, claiming that they have not eaten for many hours, or have already taken laxatives at home, but usually these tricks are fruitless. The topic of trust deficit increases as it is supported by further deprivation: "When they admitted me, they couldn't believe my contractions were so close together and so long ... My husband called. And they made me turn off my phone" (Marina 2008).

The commanding intonations of the medical staff, noticed in the texts of maternity hospitals, further disidentify the woman with her own body, adding to the confusion caused by a new bodily experience. Paradoxically, high-quality theoretical training in the courses of expectant mothers often determines the deep discursive conflict that a woman who is accustomed to listening to her 
body goes through, juxtaposed with the fact that the stages of her birth are determined by the medical staff as follows: from "you aren't even screaming" to "okay, time to put you in stirrups" (see, e.g., Petrova 2009: 354, 361). Only a few people insist on the correctness of their own feelings and demand changes in the birth plan, making sure to note this in their stories: "I told them off", "I went up to her and hit the desk", "I barked out my demands", and so on. It is important to remember that one of the functions of the autobiographical narrative is to serve as a framework for self-identity, so these statements can also be interpreted as rhetorical decorations that allow the woman in labor to retrospectively assert their own subjectivity, comparable in significance to the will of the medical staff. Thus, in women's narratives, one can find a struggle for subjectivity developing in spite of procedural realities that lower the status, where the author manages to show it at least by rhetorical means.

\section{Prenatal ward}

The hours of labor contractions begin in the prenatal ward. From the outside, they look like an inactive waiting, but from the inside, from the position of the narrator, this is the most dramatic, seemingly endless stage, through which a woman passes in pain and subjective loneliness, experiencing a loss of control over the body and the complexity of interaction with the hospital staff.

\section{Birth pain: Self-encounter and scenario collapse}

The main issue of this narrative stage is the description of the growing pain and associated fear. It is important to note that most of all pregnant women are afraid of facing the pain. They try to clarify its nature and strength through questions in the comments; thus, the request for a description of labor pain is supported on both sides: narrators try to find words for the experienced feelings resorting, mostly, not to metaphor, but to 'increasing the volume' through using all upper case letters and pedaling the main meaning of words, and the audience greedily listens to this.

I was skeptical about women who YELL while in labor and told myself the pain is bearable and you can grit your teeth and bear it ... Pain is something you CAN BEAR ... I was even able to live through THE UNBEARABLE!!! It's torture... I SCREAMED bloody murder for the whole 5-6 hours. And it wasn't because I don't have any self-control or because I'm a brat or whatever else - THAT WAS HOW I REALLY FELT. (Jane 2006) 
Birth pain, revealing the failure of speculative schemes, turns out to be the locus communis of eternal maternal initiation, opening up the possibility of identification with any of the mothers who lived on our planet. ${ }^{7}$ Pain becomes an end-to-end plot of 'women's genealogy', preserving its ambivalent nature:

I had one persistent thought: 'These people are crazy. My mom. My grandma. All the women who've ever given birth to a second or even a third child, crazy! It's just not normal - consciously come here a second time. It's insane. Schizophrenia. Sadomasochism.'(Shepka n.d.)

Pain also sets the value of a child who is "worth the pain".

It is at the stage of labor pain that unexpected behavior occurs most often. In the experience of pain, a woman meets a hitherto hidden side of her physicality, sensitivity, and will. It can be cautiously said that women who are characterized by high standards and demands on themselves and others are less likely to show satisfaction with how they are going through the birth process. Markers of a disappointing discrepancy with the intended scenario are the words: "Everything went wrong", "I didn't want it to be like that and could have never imagined it would be like that".

The unpredictability of childbirth, which doctors often talk about, is reflected in the coexistence of paired narrative scenarios (natural childbirth and caesarean section), among which one - emergency caesarean section - occurs directly during childbirth and, therefore, does not allow mental preparation for it in advance. So, it is an emergency caesarean that is understood by women retrospectively, over a long period of time. Without specifically focusing on this story, I note that the narrators offer several techniques for dealing with the unexpected that has invaded their life: "You have to find strength within yourself to defeat these negative emotions. You should understand that it was the ONLY way to save your baby's life. Consider it your sacrifice for your child's welfare" (Kasparova 2002). Although physical recovery after operative childbirth is imminent, the plot continues to develop, because it is the mother who feels responsible for the appearance of the 'caesarean', whose beginning of life in public opinion is considered less successful than in natural childbirth.

Therefore, facing a birth pain often occurs in stories about the birth moment that runs the script change due to the initiative of relatives worried about the state of expectant mothers. Evidence of this perception of pain and its influence on what happens in childbirth is abundant (Margo 2009, etc.). 


\section{Medical staff: On whose side?}

With pronounced discursivity, childbirth stories are deeply personal, where individual memory is maintained conventionally: the condition 'write only about your experience', not including the stories of your wardmates, is displayed on many internet sites and activated in the comments. A kind of maternity travelogue from the beginning of labor to delivery is marked by a search for allies and helpers among the staff of the hospital.

In traditional culture, the entire burden of accompanying and symbolically filling the birth process lies with the midwife. Although Ekaterina Belousova (1999) considers obstetricians as direct heirs of midwives, there are clear differences. In contrast to the midwife who accompanies a woman during childbirth from the beginning to the end, doctors are distanced from women in labor, often anonymous. Teams change depending on the order of duty, while the woman continues to give birth. Often women in childbirth do not know the names of doctors and midwives, sometimes giving rationality to these arguments: "In childbirth, apparently, euphoria and encephalopathy occur, because I asked the doctor's last name several times, but I did not remember" (Akishina 2005). Women's attempts to establish personal contact with doctors are not always successful, but remarkable for their constancy. In texts, they are mostly presented as women's initiative, choosing a personal, non-systemic style of relations.

The need for a person nearby is noted by many women in childbirth. "The midwife came in and sat down beside me, rubbed my stomach with her cool, gentle hand, and believe it or not, I felt so much better. As soon as she left, the pain and fear took over again" (Zlato-serebro 2009); "After they came in to give me a shot to sleep, I hugged the nurse, and held her tight and then was able to make it until they could give me anesthetics!" (Kozupitsa 2009)

In the statements of doctors, women also highlight not the physiology of pain, but its moral value. Their conversations with doctors describe pain as an inevitable 'redemption': "The doctor... gave me a strict judgmental look: 'Ok, get ready for some terrible pain. Unbearable pain. And no kind of pain relievers are going to help you. So get ready!"' (Olga 2001). At this stage, pity turns into something that hinders, depriving you of strength: "Ladies, my best advice: don't feel sorry for yourself during labor!! It will only make things worse. It's really hard to push when it just makes the pain worse" (Margo 2009).

Thus, if the severity (but not rudeness) of the staff in these moments in general is accepted by the expectant mother as inevitable in an emergency situation, the medical manipulations are often assessed by mothers as physically unnatural for her (such as check-ups on an examination chair during 
a contraction). On the other hand, doctors, taking the 'side of the pain', protect the woman and child from irrational actions the woman in labor could take if she were in complete control, driven only by the desire to get rid of the pain. In this case, women are grateful to doctors after the fact for providing more acceptable conditions:

All of a sudden, I had a terrible pain in my abdomen, unbearable pain, like I had a boiler inside me; everything is heating up and wants to come out. I'm screaming, they check my cervix. Yes, sweetie, they said, you would have given birth on your back, would have torn terribly. You should be thankful that we practice vertical birthing. (Oksana 2005)

\section{Medical staff: Roles and functions}

In the narratives of women who gave birth, the roles of midwives, gynecological surgeons, and anesthesiologists are different. ${ }^{8}$ Obstetric nurses-midwives are often referred to either as a source of verbal aggression or, conversely, with gratitude. Surgeons have a radical influence on the future of maternal and female destiny. The medical staff also inherits the prophetic functions of midwives, who, according to traditional beliefs, can reveal the future fate of the child. For example, in one narrative, a nurse delivering twins suddenly mentions that she is also a twin, and her sister died in childbirth; in turn only one of the twins delivered by the woman in labor survives, the second dying due to an error by the medical staff. The medical staff themselves have a number of professional tips that they share with incoming patients: "The birth will go as the enema goes!" (Liudmila n.d.) Even agreements with doctors can be filled with performative power, because they occur in a special place and at a special time (Calypso 2010).

In women's stories, anesthesiologists are singled out in a special group taken that the measure of pain and the fullness of a woman's presence at her own birth (concerning the epidural or general anesthesia) depend on them. Communication with the patient is an important part of their official duties; they know the woman in labor by name and build quite long dialogues with her. Anesthesiologists, more often than others, become involved in stories about doctors being lightly flirtatious: after all, the meeting with them often occurs in a 'normal' state and not during labor. They are joked with, needled, begged, reasoned with; they use a wide range of rhetorical reactions.

Examples of aggression (often verbal) on the part of women in childbirth in their narratives are expected to be less than the opposite, but they occur. As 
a rule, their existence is justified for the narrator by subsequent erroneous or rude actions of the doctors; i.e., the motivation has a prospective, anticipating further conflict: ${ }^{9}$

I felt like I was being torn apart from the inside out. I screamed. She [the midwife] says:

'What are you yelling at?'

And I scream 'GO TO HEELLL!'

'Sure, thank you'.

And she leaves. (Kukusikii 2019)

In fact, the woman and the doctors are fighting against her organism, nature itself, which at the moment the woman is aware of as beyond her control. The doctors fight and support a woman's body at the same moment. ${ }^{10}$ In this case, removing the obstacle with actions and words of a frightened woman in labor is quite logical, but after some injections her ability to maintain self-control sharply decreases, which only increases the alienation from her own body and distrust of the staff.

After neutralizing the nervous patient with injections, doctors are forced to mobilize her will with more aggressive and louder communication.

Then they gave me a shot to go to sleep, but it didn't help the pain, I just dropped off to sleep between the contractions, but when the contractions started, I'd wake up again. Thanks to the midwife, she really helped me during that time, she came in every once in a while and talked to me really sternly, so that I would wake up, and look at her ... She's the only one I remember. Who else was there? I have no idea. The only thing I remember is her big gray eyes and her stern voice! (Ismailova 2012)

Thus, in the current state of affairs, there is a vicious cycle: not trusting a woman burdened by her 'nerves', doctors try to eliminate the interfering factor, and then they have to use ruder, more aggressive and commanding methods to motivate her to cooperate. In the last fragment, the strictness of the labor nurse is welcomed, since it promotes concentration and serves as a beacon to get out of pain when the usual means of control and interaction are not available due to a difficult physical condition.

Women in labor especially remember the words and actions of the medical staff, which contrast strikingly with their condition, and emphasize the routine nature of what is happening for doctors. These memories are also ambivalent: they are defiantly dissonant to the experience of women in labor, exhibiting a complete lack of empathy, but they also serve as a kind of anchor in relation 
to the everyday world, from which the woman in childbirth is temporarily separated, but whose steadfastness supports confidence in their own successful outcome:

The medical team was having a good time laughing at me. Irina, don't do that. Breathe... Irina... don't groan, breathe... and later behind the maternity hospital, the grass was burning and the firemen came... the whole medical team came in my room so they could look out the window and watch how the young men put out the fire... The fire was in me, I was burning up, I was shaking from pain... I was about to eat the bed, I was in so much pain... and all the while they were distracted by what was going on outside my window, making comments about the handsome firemen, laughing, and in between all of this every once in a while telling me, Ira, push... (Calypso 2010)

\section{Responsibility and guilt in a crisis of subjectivity}

In the part of the stories related to the prenatal ward, doctors are represented as episodic and unfaithful allies of women in labor because contact with them is fickle, their actions are not predictable for women suffering from labor pain, their intonations range from strict and even rude to routine-empathic.

However, complications in childbirth, which are detected in the labor room, are expensive to both parties (the mother and the doctors), as they influence the future maternal life of the woman, the child's condition and the extent of legal liability for the medical staff. Generally, a woman includes in her story medical terminology defining the cause of the complications (as doctors called it: "clinically narrow pelvis", "weak labor activity", “double entwining”, etc.), but the semantic development of this line in narratives becomes the experience of responsibility and guilt, as well as their distribution between the actors of childbirth. ${ }^{11}$

According to the law in Russia, a woman must give written consent for any medical procedures. This often happens in an environment of psychological pressure and, in fact, lack of full-fledged choice, because the woman in labor is afraid of pain and cannot adequately assess all the consequences of her actions. Aggression on the part of doctors can be explained by the wish to protect the interests of the child, but the mother is forced to take the blame for the harm caused to the baby (Mashinova 2020). 
However, it would be wrong to assume that repressive mechanisms are supported only by the medical community. The problem is systemic and rooted in Russian society as a whole, as evidenced by the texts generated by women. Similar social mechanisms work inside the maternity hospital, which have already been noted in other closed systems: the army, boarding schools, prison, etc. Verbal and behavioral repression may be habitual and not reflexive, but it is easily recognized in the text. Here is a typical example where a woman is the object of manipulation, being in the position of a punished child who has to seek permission for any action:

I was dying to get up and walk around. I called the nurse. She gave me permission. I walked around for about ten minutes, it helped a little. Then a different nurse came in and started yelling at me, made me get back in bed and connected me to that apparatus again. I had a strong urge to push, but they wouldn't allow it. They said the head had to crown first. Don't move, just breathe. I begged someone, anyone, to stay with me, but to no avail. At that point, I put my hand down there and realized I was touching the head of my baby! I start to panic. I yell, the head is coming out! The team comes running in, someone yells at me for making a mess by spilling water on the table. (Evgeniia 2012)

In general, the repetition of the rapport "ask - not allowed", "did - scolded, praised" is one of the most frequent mechanisms of a text about childbirth. In the analyzed cases, most informants allow themselves to be treated in this way, because such relationships are not unique and all those who have passed elementary educational institutions are familiar with and adapted to them; the repressiveness is recorded almost without value, simply as a fact of reality.

\section{Delivery room: Return to cooperation}

So, the most dramatic moments of the narratives are over; what is the final part of the birth remembered for? The pain does not go away, on the contrary, the sense of inevitability of disaster increases:

I thought about what I would compare my experience to-it's like you are going to pop a melon. And you totally understand that it's not possible, not even a little... And most importantly, it's like no one understands your problem, like you are completely alone with your feelings - feelings of complete helplessness. (Gorlova 2017) 
However, at this stage, attempts require coordinated work of women and the medical staff. Women report that it is at this stage of delivery that control is once again given back to them: "Here you are completely responsible for the birthing process of your child" (Marchenkova n.d.). The woman finally feels the child is again the goal for which she came to hospital.

I squatted down on my haunches and continued to push even harder. It was like coming to the end of a long-distance cross-country race. When you have very little strength left, and every bone in your body is hurting, but the goal is so close, you're almost there! (Olga 2001)

The transition to the delivery room means the end of the process is close at hand, and therefore is colored with positive emotions. The asceticism of the situation does not frighten them; cultural memory kicks in at this point, offering stereotypical knowledge of traditional places of birth: "Now I understand how our ancestors gave birth in the fields or in the bathhouse - at that point, you don't care where you are or who's around you" (Olga 2001). It is interesting that women often note the everyday nature of the 'last march' to the maternity chair (in flip-flops). Most likely, in this consistent detail of collective memory, the principle of contrast works: most women still remember the scope of the wedding and the special care of relatives during pregnancy. But in the gateway to motherhood, you have to walk in dressed in a washed-out hospital shirt on half-bent legs, clutching your stomach instead of riding in a troika sleigh with bells jingling.

I finally heard the long-awaited announcement... We're going to the delivery room...!!!!!!!!!! and I waddled like a penguin... I felt my baby between my legs... and I was so scared to make any false move ... was very proud of myself, because no one had to carry me, or even help me ... I made it there all by myself and got up on the chair of torture. (Calypso 2010)

The transition to the delivery room is not only a sign that the hard work is coming to an end, culminating in meeting the newborn, but also a place of cooperation between the woman and the team of doctors, returning the woman in labor to the center of attention.

The midwife commanded me to push during the contraction, but I didn't feel them. Then the doctor and I decided she would lightly tap on my stomach with her finger as a sign that it was time to push. Fortunately, the doctor didn't need to tap for very long; I gave birth to my son at 21:45 after just three pushes. (Matiz 2015) 
It is in this part of the memoirs that the collective 'we' appears, including the woman in labor and the doctors, and often the child:

There were four people around me and, as a team, we started to give birth together ... The only thing I did wrong - was suddenly laying down, when a contraction was over. But the attentive eye of the doctor noticed my oversight and we quickly corrected the situation. (Chemyakina 2009)

Once in the chair, only a few minutes away from the happiness of meeting her own child, women remember the scolding of doctors during labor almost without malice, although, according to those who have given birth and even their husbands, the woman is often berated here: "I didn't even feel when my baby was coming out, I thought that he hadn't even crowned yet, but they keep that from you and just berate you saying you don't really want to deliver your baby" (Ismailova 2012).

The story about the delivery can be accompanied by comical moments (wet the doctor, mother, etc.), serving as a discharge of the previous tension. The behavior of a woman in labor is often verbally evaluated by obstetricians, and then rewards follow (“They praised me for my strength (I didn't scream not even once) and my positive attitude ... Later they rolled me over to the telephone at the nurse's station and let me call Sasha and mama" (Olga 2001)), or punishment ("The midwife told me she wasn't going to put my son on my stomach because he was tired from being born because his mama couldn't even deliver a baby right" (Marchenkova n.d.)). The priority of medical procedures over the desire and right of the mother to feel physical intimacy with the child at this moment is generally recognized by new mothers who are satisfied with the moments when they are shown the child or allowed to put it to the breast. ${ }^{12}$

The woman here is often in a state of euphoria, overwhelmed by tears of joy and gratitude to doctors and midwives:

They brought him to me, showed him to me. Oooh! It's such a miracle, a real miracle, I wanted to burst into tears of joy and happiness, but because of my state of shock, the tears didn't come for some reason. Because my head was spinning from the shock, I begin talking nonsense, saying the doctors were saints, thank you so much. Finally an elderly lady scolded me: lady, stop acting like that. (Marchenkova n.d.)

According to the law of the emotional pendulum, the one who holds back from crying out in pain also wants to repress the tears.

The delivery of the afterbirth is recorded in narratives as an option; it is mentioned only in passing when discussing how relatives are notified about the birth of the baby. 
The final point of communication between the medical staff and the woman is a ritual question: "Will you come back for a second child?" The answers from the same woman often differ depending on what stage of the process she is asked. For instance, while in the birthing chair, her answer contrasts to her answer after the birth. Her answers are expressed sharply like "No way!", "only caesarean", "let my husband come for the second one", while these fresh impressions change after weeks, months, and years to "certainly". This change of position is more than understandable, but the very rituality of the question is interesting to interpret. Perhaps, on the part of doctors, this is a ritualized sign of feedback, which completes the initiation by returning to the normative, dialog mode of the woman and obstetricians. It is significant that any response is considered acceptable: a negative one increases the value of the child gained through suffering, while a positive one eliminates all the negative experiences of childbirth, including the pain and rudeness of the staff.

\section{Postnatal ward: Instructing young people as a narrative coda}

It is interesting to mark that there are surprisingly few descriptions of the first impression of a newborn in the birth narratives, and it is clear that the focus of the narrator and the audience is not on the baby (cf. Marander-Eklund 2020). The impressions are rather a continuation of the evidence of the altered state of the participants in the process:

They brought me my boy. My first reaction: he's ugly, ruddy, swollen, bald, with some kind of thick balm on his eyes ... And I couldn't for the life of me remember his length and weight, I asked several times, and finally wrote it in my phone. Later, in the postnatal unit, I found that information on his medical bracelet and laughed that I didn't think to look at the cheat sheet. (Matiz 2015)

The cadence of the narrative is giving a formula for their readers to follow if/ when they give birth. From brief: "Girls, give birth, don't be afraid! Good luck to everyone" to the expanded and paradoxical:

While I was in hospital to give birth, I tried to remember how painful it was, because I had heard that you forget the pain and you want to give birth again. But I didn't want to repeat that experience! ... In summary, ladies, it's very painful and scary giving birth, so you should do it! Because kids are a reward from the Lord, and there is no better gift than the gift of motherhood. The result of your giving birth is so great and precious, 
and worth the sacrifice even more than days of pain and exhaustion. (Ismailova 2012)

In the context of internet sources, this information is a confirmation of the mother's initiation, the essence of which is to overcome pain and fear.

Ladies, it was so painful... indescribable pain... and when I called my husband, I told him if he wanted a daughter, he would have to give birth himself. I pass... P.S. After almost 9 months... I want another baby and I'm scared. (Calypso 2010)

\section{CONCLUSION}

As it has been for centuries, childbirth is one of the most important episodes in a person's biography. The vast majority of texts about second births begin with the moment of reflection on the first, and the duration of the pregnancy is devoted to finding the optimal conditions for a particular woman for the next birth. That is why the analysis of 'unprepared' first acts of childbirth should precede further research on alternative childbirth practices, because they are called natural, in fact, secondary in choice and marginal in quantity, in opposition to the generally accepted practice of childbirth in hospital.

In addition, birth narratives become the texts that are constantly present in every culture, thanks to the interactivity of Web 2.0, available to a huge number of users. These narratives speak about being in an altered state of consciousness and returning to the 'normal world'. In these autobiographical narratives, authors often use the possibilities of active compensatory subjectivity provided by the very act of creating a text. Requests from the readers (determined through the reactions of commenters) vary depending on their status. For those who have not yet given birth, it is important to translate cognitively learned concepts into language representations:

I'm afraid of giving birth and that's all I can think about all day ... Ladies, what does a contraction feel like? What about pushing? Of course, everyone has a different experience, but maybe it will help me to be a little less panicked. (Petrukhnova 2020)

This language is constantly in need of updating, and although it is very difficult to describe labor pain and other physiological processes in a new way (the narratives are formed discursively), it is popular for the audience to request fresh stories: "I'm laughing after every your sentence; for those who are afraid 
to give birth, maybe they should read your article. Their fear will vanish right away.)))) Could anyone write about caesarean in the same way" (comments to Calypso 2010). Overcoming the fear of the inevitable is one of the main motivating factors of the popularity of such texts.

According to the authors, during pregnancy they used several sources of information to raise their awareness and reduce anxiety, such as literature, forums, and personal experiences of past births. These searches often become the reference points that women rely on to form their own narrative, especially its final, analytical part. In this sense, I can conclude that narratives about childbirth are not alien to the research intention - to write a text that they themselves would like to read when they are pregnant - now this knowledge is obtained by them in their own unique experience:

I'm asking myself these questions:

- Is labor really painful?

- Yes, but you'll survive.

- What if I look stupid or do something wrong?

- You're in such a state that you aren't even thinking about that.

- Is being a mom difficult?

- It's different at different times. It's pure joy, but also around the clock without days off or even a lunchbreak:)

- If I knew how difficult it was, would I do it again?

- YES! Because, beyond exhaustion, looking terrible, and other issues, there's this huge plus ...LOVE. The love that inevitably comes into the life of any mother. (Elisaveta777 2015)

Didactic endings are less common. They occur as a specific recommendation: "I want to give you ladies some advice. No matter how painful it gets, try not to lose your head. Listen to the midwife and the doctor. Read as much as you can about childbirth, so that you will be ready at least a bit" (Anonymous 2020), and generically didactic in character: "I know for sure that I'm ready to give birth again, if necessary. You'll live through it. My baby has grown now and I'm pregnant with our second one. We're doing wonderfully. But that's because we all respect each other..." (Nastia 2019).

Although the story of childbirth is most often posted on the websites of forums for women, it can also be designed as an appeal to the newborn and, in this case, asserts the uniqueness of the child's connection with the mother:

I dedicate my story to you, my little hero, who has changed my life forever ... We will discover the world together. But most important is that we have 
each other. And I'll be the only one who will know you 9 months longer than anyone else. (maksimka13 2015)

Especially appreciated (by both pregnant women and those who have already given birth) are the practices of overcoming the ordeal of childbirth, fighting fear and anxiety. Among them, as I have already noted, is a strong subjective position (granted if not by reality, then by discourse), a statement of the value of the experience as a unique one. A kind of repressive and censoring mechanism works within the community (this relates to the state of Russian society as a whole). This censorship manifests itself as a reaction to comments related to evidence of rudeness and incompetence of the medical staff, confessions of a lack of maternal love, etc., with aggressive condemnation, which, in my view, indicates a powerful demand not for the truth, but for overcoming fear.

A sense of humor becomes a lifesaver, hotly demanded by the audience. Leaving a woman in the hours of labor pain, it returns to her in the story of the experience, becoming a means of strengthening the author's position. At the same time, the comedy also touches on the 'holy of holies' - the newborn, whose acquaintance becomes the main intrigue of the future motherhood:

They laid this little blue Avatar on my breast - he quieted and you couldn't hear him breathing; I asked if he was alive, the doctor smiled ... But he's like having been colored with a blue marker, a bruise on his head - from drilling his way out of me, a big bruise on the bridge of his nose because I couldn't get his nose out for a long time - but he's still truly the most beautiful baby to me, and very manly. (bjbj2 n.d.)

In conclusion, I would like to remind you that such a contingent, the first-time young expectant mother, is the most compliant in its interaction with the system and its representatives. Any complication and aggravation of introductory procedures, such as having many children, a second or third caesarean section, the age of a woman, the presence of chronic or detected diseases during pregnancy, for example, dramatically increases the repressiveness of the system at every stage from the consultation to the maternity ward. However, the analyses of the narratives of complications during childbirth deserve a separate article.

Translated by Dana Evans and Konstantin Tsibizov 


\section{ACKNOWLEDGEMENTS}

The study was supported by a grant from the Russian Science Foundation (project No. 19-18-00221), and proofread by Dana Evans.

\section{NOTES}

1 A complete survey of literature, except for titles published in the most recent decade, is available in the article by Carolyn Sargent and Lauren Gulbas (2011).

2 The topic of aggressiveness in the perinatal culture is gaining a large following in mass media: for example, a specialized community Violence in Birth has existed on the Russian social network InContact (VK) since 2016, currently containing about 500 messages (see https://vk.com/humanize_birth, last accessed on 8 October 2020).

${ }^{3}$ Narratives of childbirth have a common structure. However, not all narratives contain all positions of the virtual supertext I have distinguished. Due to that, of about 300 total analyzed narratives, I adduce here only the most illustrative texts. Meaningful omissions of positions in some narratives are stipulated specifically.

4 Visual impressions in the materials are specifically not accented by women; yet, in a narrative of a home birth, they are significant, often reaching ekphrasises.

5 With this self-perception, the health problems of a pregnant woman are described in the mode of disidentification with the body (Matiz 2015). In general, in narratives about childbirth, everything that remains without visible consequences for the child, most often fits into a short list: "There were so many problems - with the right kidney, a short cervix, colds, conjunctivitis, insomnia, and the crowning moment, terrible hemorrhoids (three days before birth). I don't even remember all of it anymore" (Elisaveta777 2015).

${ }^{6}$ Cf. the perception of the admission into the maternity ward as a symbolic border, and the midwife as a guard in Finnish stories about childbirth (Marander-Eklund 2020).

7 For other functions and meanings of pain, see also Belousova 1998.

8 Ekaterina Belousova considers doctors as a collective hero in the function of assistant, uniting doctors of all specialties, midwives, and nurses (Belousova 1999), but I tend to differentiate the roles of the medical staff, following the authors of the stories.

9 Further biography of this woman includes cleaning without anesthesia, when the nurse claps her hand over the patient's mouth, damaged veins on both hands from intravenous drips... and the conclusion: "In general, I do not want to give birth anymore. They say I'll forget everything. My son is almost six years old, and I remember every detail" (Kukusikii 2019). The request to overcome fear, rather than the 'truth' on sites with birth stories, is rationalized, in my opinion, by aggressive responses to such stories: "Why do I need this information? I gave birth easily. No lacerations, no 
blood loss. Everything is fine. And now what? Do I need to tell the whole world about it?" (Marusya84 in comment to Kukusikii 2019).

${ }^{10}$ It is this change in the relationship style that characterizes the degree of pain and confusion more than the actual rudeness of the staff demonstrated in this dialogue:

'Oh, my God, do something, do something for the pain'.

'No... It's too late.'

'Give me a C-section.'

'You're a fool, you'll give birth yourself...' (Calypso 2010).

${ }^{11}$ It is the shifting of all responsibility to the mother that becomes an introductory motivating block in the narratives of supporters of a natural childbirth: women recount their dialogues with doctors, in which they see the reluctance of doctors to share responsibility for the course of childbirth and the health of the child.

${ }^{12}$ In the repression that persists in the Russian maternity system, there are several layers: from the common practice of childbirth in a chair, lying on the back, a pose convenient for doctors, to the inclusion of maternity hospitals in the health system (Soviet in origin) basing its activities on the doctrine that the doctor as a professional is more valuable, making the patient (as an amateur) of secondary value. All this converts childbirth from the main event in the life of the family into one of the conveyor operations of the medical institution, where the result is evaluated by issuing a product - a newborn - regardless of what the woman endures within the walls of the maternity hospital.

\section{INTERNET SOURCES}

https://www.7ya.ru/pub/birthRussia/, last accessed on 28 September 2020. http://deti.mail.ru/birthstories/, last accessed on 28 September 2020.

http://www.kid.ru/forum/index.php?showforum=9, last accessed on 28 September 2020. https://www.kemdetki.ru/biblio/stories/, last accessed on 28 September 2020.

https://vk.com/moi_rodi, last accessed on 28 September 2020.

Akishina, Irina 2005. Glavnoe - sootvetstvuiushchii nastroi. [The Main Thing Is the Appropriate Motivation.] 7ya.ru, 25 May. Available at http://www.7ya.ru/article/ Glavnoe-sootvetstvuyuwij-nastroj/, last accessed on 24 September 2020.

Anonymous 2020. Vot i nastala pora napisat' mne svoiu istoriiu rodov. [Now It's Time to Write My Birthing History.] Vk.com, 26 June. Available at https://vk.com/ moi_rodi?w=wall-80494791_13690, last accessed on 25 September 2020.

bjbj2 n.d. Rody prikhodiat obychno neozhidanno. [Childbirth Usually Comes Unexpectedly.] Kemdetki.ru. Available at https://www.kemdetki.ru/biblio/ stories/490/, last accessed on 24 September 2020.

Calypso 2010. Kak ia rozhala nedeliu! [How I Gave Birth a Week!] Kemdetki.ru. Available at https://www.kemdetki.ru/biblio/stories/7103/, last accessed on 24 September 2020 . 
Chemyakina, Cveta 2009. Samyi schastlivyi den' - piatnitsa, 13-e. [The Happiest Day Is Friday the 13th.] 7ya.ru, 1 July. Available at https://www.7ya.ru/article/Samyjschastlivyj-den-pyatnica-13-e/, last accessed on 25 September 2020.

Elena 2007. Rody: Komediino-eroticheskii triller. [Childbirth: A Comedy-erotic Thriller.] 7ya.ru, 13 February. Available at http://www.7ya.ru/article/Rody-Komedijnojeroticheskij-triller-Chast-1/, last accessed on 24 September 2020.

Elisaveta777 2015. Rozhdenie nashego angelochka. [The Birth of Our Little Angel.] Kemdetki.ru. Available at https://www.kemdetki.ru/biblio/stories/1071/, last accessed on 24 September 2020.

Evgeniia 2012. Beremennost' dlinoi 42 nedeli i rody za 10 chasov. [A 42-week Pregnancy and Birthing in 10 Hours.] 7ya.ru, 17 November. Available at http://www.7ya. ru/article/Beremennost-dlinoj-42-nedeli-i-rody-za-10-chasov/, last accessed on 24 September 2020.

Gorlova, Anetta 2017. Rody 15 chasov - ad i rai v odnom flakone! [Childbirth 15 Hours Hell and Heaven in One Bottle!] 7ya.ru, 5 November. Available at https:// www.7ya.ru/article/Rody-15-chasov-ad-i-raj-v-odnom-flakone/\#null, last accessed on 25 September 2020.

Ismailova, Nina 2012. Vse ravno eta bol' zabyvaetsia. [All the Same, This Pain Will Be Forgotten.] 7ya.ru, 22 January. Available at https://www.7ya.ru/article/Vseravno-jeta-bol-zabyvaetsya/, last accessed on 25 September 2020.

Jane 2006. Dolgii rasskaz o dolgikh rodakh. [A Long Story about a Long Birth.] Materinstvo.ru, 27 September. Available at https://materinstvo.ru/art/436, last accessed on 24 September 2020.

Kasparova, Iuliia 2002. S chego nachinaetsia zdorov'e. [What Does Health Start from.] 7ya.ru, 10 October. Available at https://www.7ya.ru/article/S-chego-nachinaetsyazdorove-Chast-1-Beremennost/, last accessed on 25 September 2020.

Kozupitsa, Julia 2009. Moi pervye rody. [My First Childbirth.] Deti.mail.ru, 20 February. Available at http://deti.mail.ru/birthstories/15410/, last accessed on 24 September 2020 .

Kukusikii 2019. Kak ia rozhala. 10 iz 10. [How I Gave Birth. 10 out of 10.] Pikabu.ru, 17 April. Available at https://pikabu.ru/story/kak_ya_rozhala_10_iz_10_6650050, last accessed on 25 September 2020.

Liudmila n.d. Rasskaz o pervykh rodakh. [A Story about the First Birth.] Homestead. narod.ru. Available at http://www.homestead.narod.ru/birth.htm, last accessed on 25 September 2020.

maksimka13 2015. Moi 6 kg schast'ia. [My 6 kg of Happiness.] Kemdetki.ru. Available at https://www.kemdetki.ru/biblio/stories/1006/, last accessed on 25 September 2020.

Marchenkova, Oksana n.d. Kak ia rozhala synuliu. [How I Gave Birth to My Son.] Kid. ru. Available at http://www.kid.ru/pregnancy/index610.php3, last accessed on 24 September 2020.

Margo 2009. Pervyi sneg, pervye rody. [First Snow, First Birth.] 7ya.ru, 25 December. Available at http://www.7ya.ru/article/Pervyj-sneg-pervye-rody-11784/, last accessed on 24 September 2020. 
Marina 2008. Kak Ilian prishel v etot mir. [How Ilian Came to This World.] 7ya.ru, 30 January. Available at https://www.7ya.ru/article/Kak-Ilian-prishel-v-jetotmir-7939/, last accessed on 24 September 2020.

Mashinova, Maria 2020. Mnogo bukv. [Lots of Letters.] Vk.com, 24 May. Available at https://vk.com/moi_rodi?w=wall-80494791_13376, last accessed on 24 September 2020.

Matiz 2015. Vse po planu. [All According to Plan.] Kemdetki.ru. Available at https:// www.kemdetki.ru/biblio/stories/8965/, last accessed on 24 September 2020.

Nastia 2019. Kak ia rozhala. [How I Gave Birth.] Myslo.ru, 9 October. Available at https://myslo.ru/club/blog/kurilka/8xvw795mokGJac_SeVU9aw, last accessed on 24 September 2020.

Oksana 2005. Moi vertikal'nye rody na stule. [My Vertical Childbirth on a Chair.] 7ya. ru, 28 September. Available at https://www.7ya.ru/article/Moi-vertikalnye-rodyna-stule/, last accessed on 24 September 2020.

Olga 2001. Rodit' po-russki. [Giving a Birth in a Russian Way.] Sanikate.narod.ru, 2 November. Available at http://sanikate.narod.ru/birth1.htm, last accessed on 24 September 2020.

Petrukhnova, Anastasiia 2020. Boius' rozhat'. [I'm Afraid to Give Birth.] Vk.com, 17 June. Available at https://vk.com/moi_rodi?w=wall-80494791_13520, last accessed on 25 September 2020.

Shepka n.d. Malen'kii komochek schast'ia, ili schastlivoe chislo dnia rozhdeniia. [A Small Lump of Happiness, or a Happy Birthday Number.] Kemdetki.ru. Available at https://www.kemdetki.ru/biblio/stories/1082/, last accessed on 24 September 2020.

Zlato-serebro 2009. Esli komu interesno... [If Anyone Is Interested...] Deti.mail.ru, 20 February. Available at https://deti.mail.ru/birthstories/15403/, last accessed on 24 September 2020.

\section{REFERENCES}

Belousova, Ekaterina 1998. Rodovaia bol' v antropologicheskoi perspektive. [Birthing Pain in an Anthropological Perspective.] Arbor mundi, No. 6, pp. 48-57. Available at http://www.ruthenia.ru/folklore/belousova1.htm, last accessed on 25 September 2020 .

Belousova, Ekaterina 1999. Predstavleniia $i$ verovaniia, sviazannye s rozhdeniem rebenka: sovremennaia gorodskaia kul'tura. Avtoreferat dissertatsii na soiskanie uchenoi stepeni kandidata kul'turologii. [Ideas and Beliefs Related to the Birth of a Child: Modern Urban Culture. Abstract of the Dissertation for the Degree of Candidate of Cultural Studies.] Moscow: Rossiiskii gosudarstvennyi gumanitarnyi universitet. Available at http://www.ruthenia.ru/folklore/belousova5.htm, last accessed on 25 September 2020.

Jordan, Brigitte 1978. Birth in Four Cultures. A Crosscultural Investigation of Childbirth in Yucatan, Holland, Sweden, and the United States. Montreal: Eden Press Women's Publications. 
Kay, Margarita Artschwager (ed.) 1982. Anthropology of Human Birth. Philadelphia: F.A. Davis. Available at https://archive.org/details/anthropologyofhu0000unse, last accessed on 25 September 2020.

Kuksa, Tatiana 2019. Teoreticheskie podkhody k issledovaniiu praktik rodovspomozheniia i tekstov o rodakh. [Theoretical Approaches to Obstetric Practices Studies and Texts about Childbirth.] Meditsinskaia antropologiia i bioetika, Vol. 17, No. 1, pp. 168-200. http://doi.org/10.33876/2224-9680/2019-1-17/08.

MacCormack, Carol P. (ed.) 1982. Ethnography of Fertility and Birth. London \& New York: Academic Press.

Marander-Eklund, Lena 2020. The Birth of a Child Experienced and Narrated in the 1990s Finland. Folklore: Electronic Journal of Folklore, Vol. 80, pp. 125-150. https://doi.org/10.7592/FEJF2020.80.marander_eklund.

Mikhel', Dmitrii 2017. Meditsinskaia antropologiia: Uchebnoe posobie. [Medical Anthropology: A Handbook.] Moscow: Delo.

Mitsiuk, Natalia \& Pokusaeva, Vita 2016. Vedenie beremennosti v dorevoliutsionnoi Rossii: ot traditsionnykh praktik $\mathrm{k}$ meditsinskomu znaniiu. [Maintaining Pregnancy in Pre-Revolutionary Russia: From Traditional Practice to Medical Knowledge.] Vestnik Smolenskoi gosudarstvennoi meditsinskoi akademii, No. 2, pp. 85-94. Available at https://cyberleninka.ru/article/n/vedenie-beremennostiv-dorevolyutsionnoy-rossii-ot-traditsionnyh-praktik-k-meditsinskomu-znaniyu/ viewer, last accessed on 25 September 2020.

Mukhina, Zinara \& Pushkareva, Natalia 2012. Dorodovoi period i rody v zhizni krest'ianki poreformennoi Rossii (preimushchestvenno Tsentral'nykh gubernii). [Prenatal Period and Childbirth in the Life of a Peasant Woman in Post-reform Russia (Mainly in the Central Provinces).] Nauchnye vedomosti Belgorodskogo universiteta, Vol. 22, No. 7 (126), pp. 160-168. Available at https://cyberleninka. ru/article/n/dorodovoy-period-i-rody-v-zhizni-krestyanki-poreformennoy-rossiipreimuschestvenno-tsentralnyh-guberniy/viewer, last accessed on 28 September 2020 .

Nartova, Nadezhda 2016. Materinstvo v sovremennoi zapadnoi sotsiologicheskoi diskussii. [Motherhood in Contemporary Western Sociological Debate.] Zhenshchina $v$ rossiiskom obshchestve, No. 3 (80), pp. 39-53. https://doi.org/10.21064/ WinRS.2016.3.4.

Nekliudov, Sergei (ed.) 2001. Rodiny, deti, povitukhi v traditsiiakh narodnoi kul'tury. [Maternity Rite, Children, Midwives in the Traditions of Folk Culture.] Moscow: Rossiiskii gosudarstvennyi gumanitarnyi universitet. Available at https://www. booksite.ru/fulltext/rodiny/text.pdf, last accessed on 28 September 2020.

Olson, Laura J. \& Adonyeva, Svetlana 2012. The Worlds of Russian Village Women: Tradition, Transgression, Compromise. Madison: The University of Wisconsin Press.

Petrova, Elena 2009. Dve nedeli v roddome: ozhidanie i rody. [Two Weeks in the Hospital: Waiting and Birthing.] In: Elena Zdravomyslova \& Anna Temkina (eds.) Zdorov'e i doverie: gendernyi podkhod $k$ reproduktivnoi meditsine: sbornik statei. St. Petersburg: Izdatel'stvo Evropeiskogo universiteta v Sankt-Peterburge, pp. 344-368. 
Pushkareva, Natalia \& Mitsiuk, Natalia 2015. Gendernye razlichiia v vospriiatii rodovogo akta ( $\mathrm{k}$ istorii rossiiskoi dvorianskoi povsednevnosti kontsa XIX nachala XX v.). [Gender Differences in the Perception of the Childbirth Act (To the History of Russian Noble Everyday Life of the Late 19th - Early 20th Centuries).] Nauchnye vedomosti Belgorodskogo gosudarstvennogo universiteta. Seriia: Istoriia. Politologiia, No. 13 (210), pp. 133-141. Available at https:// cyberleninka.ru/article/n/gendernye-razlichiya-v-vospriyatii-rodovogo-akta-kistorii-rossiyskoy-dvoryanskoy-povsednevnosti-kontsa-xix-nachala-xx-v, last accessed on 28 September 2020.

Pushkareva, Natalia \& Mitsiuk, Natalia 2017. Rodovspomozhenie i kul'tura detorozhdeniia $\mathrm{v}$ noveishei zarubezhnoi istoriografii (1975-2015). [Culture of Childbirth and Obstetrics in Contemporary Western Historiography (1975-2015).] Etnograficheskoe obozrenie, No. 4, pp. 147-163. Available at http://journal.iea.ras. ru/archive/2010s/2017/no4/147.htm, last accessed on 28 September 2020.

Radzinski, Viktor 2017. Akusherskaia agressiia v. 2.0. [Obstetric Aggression V. 2.0.] Moscow: StatusPraesens.

Raynor, Rachel Lucia Judith 2005. Storied Beginnings: Description and Analysis of Internet Childbirth Narratives. Diss. (PhD Thesis). University of California. Available at https://search.proquest.com/openview/0c00aa19711da2d7a180 $7496863226 \mathrm{a} 1 / 1$ ?pq-origsite $=$ gscholar $\& \mathrm{cbl}=18750 \&$ diss $=y$, last accessed on 28 September 2020.

Sargent, Carolyn \& Gulbas, Lauren 2011. Situating Birth in the Anthropology of Reproduction. In: Merrill Singer \& Pamela I. Erickson (eds.). A Companion to Medical Anthropology. Chichester, West Sussex \& Malden, MA: Wiley-Blackwell, pp. 289-304. https://doi.org/10.1002/9781444395303.ch14.

Shchepanskaia, Tatiana 1999. Mifologiia sotsial'nykh institutov: rodovspomozhenie. [The Mythology of Social Institutions: Delivery Care.] In: Konstantin Bogdanov \& Aleksandr Panchenko (comps.) Mifologiia i povsednevnost': materialy nauchnoi konferentsii (Sankt-Peterburg, 24-26 fevralia 1999 goda). St. Petersburg: Institut russkoi literatury Rossiiskoi akademii nauk, Vol. 3, pp. 389-423. Available at http://www.poehaly.narod.ru/repr-1.htm, last accessed on 28 September 2020.

Toporov, Vladimir 1995 [1971]. Peterburg i "Peterburgskii tekst russkoi literatury" (Vvedenie v temu). [St. Petersburg and "St. Petersburg Text of Russian Literature" (Introduction to the Topic).] In: Vladimir Toporov. Mif. Ritual. Simvol. Obraz. Issledovaniia v oblasti mifopoeticheskogo: Izbrannoe. Moscow: Progress - Kul'tura, pp. 259-367. Available at http://biblio.imli.ru/images/abook/folklor/Toporov_V.N. Mif._Ritual._Obraz._Simvol._1995..pdf, last accessed on 28 September 2020.

Trevathan, Wenda R. 1987. Human Birth: An Evolutionary Perspective (Foundations of Human Behavior). New York: Aldine De Gruyter.

Zdravomyslova, Elena \& Temkina, Anna (eds.) 2009. Zdorov'e $i$ doverie: gendernyi podkhod k reproduktivnoi meditsine: sbornik statei. [Health and Trust: A Gender Approach to Reproductive Medicine: A Collection of Articles.] St. Petersburg: Izdatel'stvo Evropeiskogo universiteta v Sankt-Peterburge. 
Natalia Gramatchikova $(\mathrm{PhD})$ is Senior Research Fellow at the Center of History of Literature at the Institute of History and Archeology of the Ural Branch of the Russian Academy of Sciences, Russia. Her main research areas are autobiographies, ego-documents, familial and historical memory, history of Ural literature and periodicals.

n.gramatchikova@gmail.com 


\title{
THE BIRTH OF A CHILD AS EXPERIENCED AND NARRATED IN THE 1990s FINLAND
}

\author{
Lena Marander-Eklund \\ PhD, Professor \\ Department of Folklore, Åbo Akademi University, Turku, Finland \\ lena.marander-eklund@abo.fi
}

\begin{abstract}
In this article, I examine the way Swedish-speaking first-time mothers living in Finland narrate their experience of giving birth between 1993 and 1997. The object is narrating about the moment of birth and experiential dimension of giving birth. This includes an analysis of stylistic means used in narration, and the points of narration. The material consists of childbirth stories told by 14 Swedish-speaking first-time mothers in interviews during the 1990s. I define the story as a personal experience narrative. The stories show that the women's experience is embodied. The birth-givers are more focused on giving birth than giving birth to a child and they relate to ambient norms and values in their narration.
\end{abstract}

Keywords: childbirth narratives, experience, interviews, narration, narrative style

\section{INTRODUCTION}

“And so, then and... but then he finally arrived."(IF mgt 1994/55)

The quote is a part of a childbirth story by Carita, one of my interviewees, describing the experience of birth. The narrative is constructed from many details and by dramatic means, but nonetheless it seems that Carita herself has little to tell when describing the moment of birth. Birth does not become the climax of the story, even though it would be natural to expect so. The peak of the story does not coincide with the peak of the experience.

In this article, I examine the way first-time mothers narrate their experience of the moment of giving birth. The object is, on the one hand, telling about the moment of birth and, on the other hand, the experiential dimension of birth. My material ${ }^{1}$ consists of childbirth stories told by 14 Swedish-speaking firsttime mothers in interviews conducted in Finland in the 1990s. The names I have given the interviewees are encrypted, based on the alphabet in the order 
that I interviewed them (Anita, Benita, Carita, and so on). The mothers lived in Turku and Parainen, and I contacted them through maternity counselling services in both cities. The women decided on their own participation and thus most were motivated to tell me about their experiences. Their motivation to participate was, for example, the need to talk about their childbirth experience, the possible interest of other mothers in hearing about their experience, or a sense of duty to participate in scientific research. I interviewed these women several times between 1993 and 1997. ${ }^{2}$

I define the birth experience as a personal experience narrative where the experiences are narrated in the first person singular form. Personal experience stories are also dramatic and truth-based (Stahl 1977: 20; Koskinen-Koivisto 2013: 29). In this paper, I use a broad definition of the concept of narrative, meaning the narrative consists of retold events; it has an internal structure and includes some kind of peak (Labov 1972; Adelswärd 1992). The story includes causes and consequences and involves evaluation. At the same time, narration is a form of self-representation: it is used to present oneself. It is a perception of experiences in which the interaction of form and meaning is central. This means that how something is told is as interesting as what is expressed (Nylund Skog 2002: 17). It is also a way of presenting "the way things seem to us" (Herman 2009: 145). These elements are also found in childbirth stories. They consist of experienced events with clear cause-and-effect relationships and a problem to be solved. The narrative reflects the values and norms associated with childbirth, but at the same time the way that the mother values and evaluates events.

Although I use a broad definition of narrative, I want to separate childbirth narratives into their own group. They are very consistent narratives with a precise beginning and end. The material was formed in the interview situation in response to my prompt to "tell me how your birth went, from start to finish". Some women presented their experiences relatively briefly and referentially within minutes. Others outlined their experiences as long, detailed, very cohesive stories lasting 15 to 30 minutes. I analyse the narrative formula that includes the moment of birth as well as the stylistic means of constructing a narrative that culminates in the telling of the actual birth. In addition, I analyse the experiential dimension of the story, in which the evaluation of the experience is central. So, my article is built around two key themes - the perception of the moment of birth and the experiential dimension of childbirth. First, I will briefly provide a background for birth stories as a genre and childbirth in the $1990 \mathrm{~s}$, the time of my research. 


\section{BACKGROUND TO BIRTH STORIES}

\section{Birth stories as a genre}

Childbirth has been described in different ways at different times. The most famous birth story in Christian culture is probably the Christmas gospel description of the birth of Jesus. There are tales and stories about birth. Various thoughts about pregnancy and childbirth have also developed into beliefs. These include, for example, perceptions of how the gender, appearance and characteristics of a future child could be affected in different ways, or which actions should be taken to facilitate childbirth (Tillhagen 1983, 1985; Koivu 1982; Wessman 1952).

Contemporary stories, in turn, can tell how a woman cracks from navel to lumbar spine because, contrary to better knowledge, she has called for natural childbirth (Klintberg 1986: 138). There are plenty of descriptions of childbirth in fiction, and in scenes in movies and TV series. In older films, birth takes place behind locked doors, while in contemporary filming the viewer is involved in the course of events. Childbirth stories of public figures are available in women's magazines, and tabloids report on the complications of childbirth that are supposed to be of wider interest. In addition, the medical and popular scientific literature on childbirth has, from time to time, published an obstetric birth report. Nowadays, it is common to publish your own birth story on the Internet.

What has been considered an inappropriate topic and what has been acceptable has varied over time, place, and situation. Talking about childbirth was still a matter of privacy and taboo in Finnish society in the 1940s and 1950s. Both pregnancy and childbirth were topics that were not mentioned but were silently ignored (Wrede 1998: 113). The silence was due to the fact that pregnancy and childbirth were considered shameful and also as a dangerous situation and therefore pregnancy had to be hidden for as long as possible. This silence led to ignorance. There was no talk about pregnancy and childbirth, but children were perceived to be a natural consequence of marriage (Marander-Eklund 2014: 82). Historian Yvonne Hirdman writes about the double silence associated with a woman's bodily functions, which "echoes the silence in which these women grew up and in what they carry forward" (Hirdman \& Bohman \& Rörslett 1995: 48). Hirdman interprets the silence as being based on shame about femininity and a sense of worthlessness. However, silence at the same time reflects the secret pride of femininity. According to Hirdman, the weakening of the taboo was influenced by sex education at school and awareness-raising campaigns in Sweden beginning in the 1930s (Hirdman \& Bohman \& Rörslett 1995: 49). 
Ethnologist Hilkka Helsti has estimated that this taboo disappeared in Finland when women got used to talking about pregnancy and childbirth while visiting a maternity clinic (Helsti 1995: 150). The changed attitude towards birth-related taboos can be seen in the life stories of women of different ages. Taboos and shyness no longer prevent women from talking about childbirth, probably due to the influence of the media and popular psychology (Mattsson 1998: 165). Childbirth is no longer considered a particularly private matter. Overall, attitudes towards sexuality have generally become more permissive. Society has changed at the same time as the private sphere of life has democratised; both bodily and sexual issues are discussed more openly (Giddens 1995). Sociologist Kristin Mattsson (1998), who used life history material as a starting point, has stated that younger women have patterns and linguistic means of talking about childbirth. Corporeality is strongly present in their narratives. Talking about childbirth has become legitimate and a daily routine for new mothers. Since the $1990 \mathrm{~s}$, midwives have discussed childbirth with every expectant mother, going through the course of events based on medical record. The purpose of the conversation is to help the woman adjust to her role as a mother and reduce her feelings of helplessness (Kivivirta et al. 1994: 19).

\section{Childbirth in the 1990s Finland}

In 1995, more than 60,000 children were born in Finland, which was considerably less than in the previous year. The average age of first-time mothers rose. In 1995, it was 27.8 years (Gissler \& Toukomaa \& Virtanen 1996: 2). The reason for the decline in birth rates is seen to be related to lifestyle rather than economic factors (Salmi 1994: 67). Childbirth is a physiological, bodily event, but the perceptions and norms associated with it have been very different at different times and in different societies. Perceptions of a natural and normal childbirth have varied (e.g. Oakley 1993: 124). The mother's perceptions and expectations of the upcoming event are greatly influenced by the information she has received from the media, expert literature, coaching courses, and other people's stories (Nylund Skog 1998).

In addition to perceptions, the conditions of childbirth and the persons assisting have varied. The presence of the becoming fathers during preparation and childbirth has been quite common in Finland since the 1970s (Jordan 1993 [1978]; Öberg 1996). The debate in society about childbirth gained momentum in the early 1970s, at the same time as other women's issues were being discussed (Nätkin 1997). Since the early 1980s, proponents of natural childbirth 
have been part of this debate, emphasizing the experiential side of childbirth (Odent 1986).

In 1944, statutory municipal maternity counselling was initiated, which meant investing in preventive care and counselling during pregnancy (Hänninen 1965: 234; Schoultz-Ekblad 1988: 44). Today, maternity clinics run courses to prepare parents for childbirth. In the 1990s, the courses emphasized the psychoprophylactic method, which aimed at the active participation of both mother and father in childbirth. The guide under the heading We are expecting $a$ baby, distributed to all future parents, highlighted childbirth as a natural event. It was also emphasized that families can express their wishes about the postpartum position and the time of treatment. Home birth was not recommended because it was considered to involve risks (Vi väntar barn 1995, 1997). The maternity field of the 1990s was characterized by a discussion of natural childbirth (Fjell et al. 1998). The ideas of natural childbirth with its right to self-determination were raised by, among others, the Active Childbirth Association (Klemettilä 1996: 28).

Attitudes towards pain and pain relief during childbirth have varied at different times. The debate over pain started to receive attention in the 1990s as studies showed that women feared labour pains (Suonio et al. 1993). However, at the same time, expectant mothers felt that their fear of giving birth was not taken seriously (Saresma \& Ruotsalainen 1998). In the mid-1970s, women fought for more effective pain relief, and the demand was met by increasing the number of anaesthesiologists (Hollmen \& Jouppila \& Työläjärvi 1987). Relatively quickly, the debate turned to support a more natural relationship to pain. The natural movement emphasized the positive side of pain: the pain was not pathological but active, positive, and soft - something that only women who gave birth naturally would have known (Miettinen-Jaakkola 1992: 44). Childbirth pain relief has increased rather than decreased in Finland in the 1990s, despite the fact that advocates of natural childbirth have gained a foothold (Gissler \& Toukomaa \& Virtanen 1996: 2). The review of the 1996 maternity care practice emphasized that an organic alternative should be provided instead of pharmacological relief and that the opinion of the expectant mother should be decisive. In the $1990 \mathrm{~s}$, it was popular to give birth in a semi-sitting position, on a maternity stool, or in a water bath (Salmenmaa 1998: 121). 


\section{NARRATING THE MOMENT OF BIRTH}

In women's narratives, the actual moment of birth is framed by other events that accompany childbirth. In fact, it is necessary to present the whole birth story from the beginning to the end, determined by the women themselves, in order to understand how women describe the moment of birth. Although the experiences of the interviewees are unique events, they share their experiences of childbirth in a similar way. The narratives largely follow a specific narrative pattern, to which I will return later.

I first asked my interviewees to retell the course of events. The stories begin with a depiction of the starting point situation: how, when, and where the delivery began. At this point, the women describe the events before going to the maternity hospital. Most often, they tell about their first sensations of contractions: they awoke to contractions or to the fact that their waters had broken. Narration thus begins with bodily reactions in which the mother is the central actor. Time and place are important at this point - mothers tell you where they were when the contractions started and how often they came. These events are included in a narrative that is evaluative, argumentative, and explanatory in nature. This preliminary section was included in the descriptions of most women. The decision to go to a maternity hospital is often justified by the time between contractions. Judith, who expresses herself relatively briefly, begins by saying:

Hhmm... It is said that it all started exactly like that, according to the book, so that everything happened exactly as it should. It was a few days before so I had pre-contractions, a few hours it hurt a bit and I knew that yeah, now it's starting, and then it started at night, the real pains started. (IF mgt 1995/102)

Judith assesses events, including the pain of contractions. She refers to the "book", that is, the professional literature in the field. When narrating, she compares her own experience with the normal picture of a childbirth presented in literature. In those stories where this section does not exist, the course of events has been different due to, for example, caesarean section or inducement of labour.

The stories continue with transitional events describing the arrival at the maternity hospital, which is often depicted in great detail. Central to the story at this stage is the decision to leave home and the reception at the maternity ward. There is the reception at the ward and the decision on whether the mother can stay there. The midwife acts as some kind of border guard who decides who is asked to stay and who is advised to come back later (Fjell 1998). The stories 
show that this is a matter of consultation between the expectant mother and the maternity hospital staff. Arguments in favour of the expectant mother are described in the story with references to bodily processes. At that point, the waters had broken, the cervix had opened sufficiently, or the contractions had continued long enough.

The stories continue with a depiction of events related to the opening phase of labour. This section is in the stories of all the women, despite the fact that the course of their births had taken different forms. They describe the pains and justify the use of pain relief. Dagmar says she "can't last any longer" and that she "can't cope with the pain" (IF mgt 1994/63). The pain is perceived as severe and an overall evaluation of the situation is given. It is about experiencing or avoiding pain and managing the situation and the body's reactions. Narrators describe worry and fear. At this stage, other procedures arise for the women, such as, for example, an infusion of oxytocin used to accelerate or initiate labour.

This is the longest part of the story. Similarly, the opening phase is described in the obstetric literature as the longest stage of labour, normally 8-12 hours for a first child (Saarikoski 1994 [1992]: 123). The long and gruelling physical labour of the opening phase is reflected in the stories of the mothers. Emilia felt the delivery had stopped. She tells about it with impatient and disappointed feelings and says:

And the next morning when they checked again how much it had opened, it was still that one centimetre ... And it was a disappointment that nothing really happened [laughter] even though there were pains that I started to feel pretty much like... disgusted then already. (IF mgt 1994/66)

Going forward, the woman narrates on the events related to the effort phase of childbirth. These events are given less space in the stories than the events of the opening phase. According to the obstetric literature, the effort phase in a first-time mother takes about an hour, including birth (Saarikoski 1994 [1992]: 131). The women I interviewed retell in which position the birth took place: sitting on a stool, in a semi-sitting position, or lying on the maternity bed. They narrate on what measures the staff thought were necessary to ease the birth. The effort phase is the active phase in the course of childbirth, which is also reflected in the stories. There is rarely any surrender or impatience in these parts of the accounts. In this section, too, talking about pain does not come to the fore.

From an obstetrics point of view, the effort phase is the most dramatic phase of labour, in which progress can in some cases be hindered for various reasons and the situation can become threatening (Saarikoski 1994 [1992]: 155). There is nothing in the women's stories to suggest a fear of complications. I do not 
think that means they were not afraid of complications for themselves or the child. Detailed and systematic reporting of childbirth is, in my view, one way to manage fear and keep it under control. In addition, the women knew the outcome when they spoke about it - everything had gone well. Only a few of them, according to their own assessment, were at risk. It is at this point in the story that there is no room for fear. This can be explained by the fact that the narrative in this section focuses on the actual emergence of the child, and there is simply too much happening to depict. Verbalizing fear is also not easy, and it is especially difficult in an interview situation where personal experiences are being told to a stranger.

The events described continue to lead to the goal of the whole story, the birth of a child, which most women describe. In this respect, Emilia's story is an exception. She does not really say that the child will be born at any point, but she describes the effort phase, evaluates it, and then moves on to evaluating her own experience. Judith outlines the experience of the birth herself by saying what time the baby arrived: "But so the girl was born then, at twenty to four in the afternoon" (IF mgt 1995/102). Nanny, in turn, concludes her story briefly and succinctly: "And then the boy was born... [sighs]... ten past one. And then... then it was over [laughter]" (IF mgt 1996/23). The quote shows that birth marks the end and, in this case, the end of a congruent narrative.

Only a few of the stories end as described above. Most women continue on their own without my prompting by evaluating events and telling about the encounter with their newborn child or what happened after birth. Women describe how they and the new fathers reacted to the newborn child and how they discovered the sex of the child. Women mention the weight and length of the child or describe the general condition of the child. The events are depicted with much use of evaluation. Sometimes women describe how it felt to hold their newborn baby; for example, Dagmar says:

I got the girl as soon as she had come out, so I got to keep her under my shirt for a little while, but not so that she would have started eating or something. She had me for a little while and then they sucked the mucus from her. (IF mgt 1994/63)

Postpartum events are usually included in women's stories. The women describe how the umbilical cord was cut, the wounds were sutured, and how the child was washed and weighed. This section also describes how the mother tidied herself up, took a shower, ate or called her parents, and told the big news. These events are also being evaluated.

In many accounts, the events depicting meeting the child and the aftermath constitute an ending. The women report how they were transferred from the 
maternity ward to the neonatal ward or evaluate the birth as a whole. This part could range from a few sentences to a rather lengthy statement about feelings. It constitutes the end of the story where no new events are addressed. Rather, it is a question of finalizing what has already been said or of concluding the story and returning the listener to the present, the interview situation. Here's how Flora concludes:

That's how it was then, so for me [sighing] it was a really great experience in every way. That I don't have much like ... those pains belonged there, but it was positive, seriously. That's how it went then. (IF mgt 1995/32)

Flora's concluding comment also shows that she reached the end of her story. The events described and the events forming the plot have a strong connection with the physiological course of childbirth.

\section{Birth narrative events}

The analysis described above shows that the events of the narratives can be divided into parts. The introductory part of the beginning of childbirth stories deals with the events before a woman leaves for the maternity ward and the reasons for the decision to leave. This part is characterized by a certain drama - women narrate the beginning of childbirth with varying emotions. The second recurring part deals with departure and arrival at the maternity hospital. This part is transitional in nature and is not described particularly dramatically. The third part describes the events of the opening phase in the maternity ward. Here the drama grows and intensifies in the fourth part, the effort phase. The events of this stage move the story towards the culmination, the goal of the whole story, the birth of a child. In the stories, the cause is the progressive birth and the birth of the child as a result.

Although birth is the culmination of the story, it is retold in most women's stories almost in passing. The birth itself, the fifth part, becomes an anti-climax and there is no drama involved in describing it, although the narrative always aims at it as a result of the afflictions experienced by the mother. Most continue their story even after this with a section dealing with meeting the child immediately after birth (part six). However, this is not as clear as, for example, the section on dilation. The events are hardly dramatized, but the narrative is mainly descriptive and evaluative. The part describing the meeting of the child alternates with the part describing postpartum labour (part seven). This often includes evaluative materials. The last, eighth recurring section includes a transition to the neonatal ward or an indication that the individual story is complete. 
The eight parts I found in the narratives fit very well with the narrative structure of both the obstetric literature and the complete narrative presented by linguist William Labov (1972: 363). The complete story consists of parts that include an abstract, orientation, complicating actions, evaluation, resolution, and coda. The abstract consists of a summary of the story and invites the audience to listen. The orientation presents the actors, place, time, and situation of the events. This is the part of my material that describes the beginning of childbirth. The complicating actions part describes what is essential to be told: events or problems (Arvidsson 1999). This creates a tension that then finds a solution either as an explanation for what happened or as information about how the problem was solved. The complicating actions part continues in women's stories until the end of the effort phase of labour. The evaluation is partly placed along the course of the story; partly it is placed in the report after birth. Birth corresponds to the resolution, but this also includes meeting the child and other postpartum events. The last part of the story, coda, corresponds to the final comments of the narrative.

My intention is not to examine whether the birth stories follow Labov's narrative structure, but to show that they largely follow the narrative pattern of personal experiences. In addition, I show that there is a tension in the stories between cause and effect and problem and resolution. The problem is the body working to give birth, and the solution is the birth of a child.

\section{Dramatization of birth: Stylistic means of narration}

Why does the narration of the birth itself become a narrative anti-climax? This becomes clear when examining by what kind of narrative means the story is constructed. In building up an anticipation and excitement in the narration, the women I interviewed used dramatic means: for example, strong adjectives, repetitions, laughter, sighs, irony, emphasis, and direct quotation (MaranderEklund 2002: 113). These dramatizing means are being used more and more effectively the closer we get to the climax of events and of the narrative, i.e. birth. It is often a matter of intolerable pain, general fatigue, or fear of losing control. Flora represents those who feel the urge to give up. She says, "So I thought now [laughter], if it doesn't come out now, then I'll give up [laughter]. She was hugely good, that midwife, and she said to me a little more. She encouraged me very much" (IF mgt 1995/32). Flora laughs embarrassingly at her desire to give up. At the same time, the quote shows the importance of the midwife's support. In a separate article on the importance of laughter in childbirth stories, my research shows that women resort to laughter when dealing with difficult 
physical matters. Laughter is used to explain, apologize, smooth, increase or decrease drama, underline or mark things (Marander-Eklund 2008).

Anita underwent a planned caesarean section. She describes how the anaesthesia began to affect her and how the surgeon came in. In addition, she evaluates the feelings of concern and fear that she felt during the operation. She goes on to recount the birth itself, mentioning its duration: "But it went awfully fast, it was about five minutes and so they took the boy out" (IF mgt 1993/22). She then moves on to judging the experience itself: how wonderful it was to see the child lifted out of her belly. Benita also describes the birth of a child with a precise expression of time: "But so that after an hour and $57 \mathrm{~min}$ utes [laughter] the boy then was born. And it was so weird [whispers] when he came out." Benita then goes straight to assessing what happened. She states that she forgot to tell how her waters broke at an earlier stage of events and how she was amazed that "it was such QUANTITIES [loud and emphatic]. It flowed [emphatically] out of me" (IF mgt 1994/60). Benita jumps back in time to explain and clarify what happened. This shows that Labov's narrative formula is only the starting point for narration. Because women know how the birth story should proceed, they can easily make deviations from the structure of the story without breaking it down. After the deviation, Benita returns to events after birth, and as a listener I have no difficulty following.

Hagar dramatized her story by repeating word for word what those present were talking about. She describes a conversation involving her husband, a midwife, a doctor, and herself. All mothers, except one had company of their husbands or partners in the birth situation, but the becoming father is quite absent in the stories. Usually, when interviewing others, the interviewees do not translate the midwives' speech from Finnish into Swedish, even though the story was otherwise produced in Swedish. For example, Hagar puts it: "It goes well" [in Finnish], while the man's encouragement is in Swedish: "Jo, jo, det går bra, det här går ju riktigt strålande" (Yes, yes, it goes well, it goes quite brilliant). The same goes for the doctor's comment on Hagar's way of giving birth: "Oh, it likes to give birth like that" (IF mgt 1995/77). The use of the pronoun "it" shows that the doctor talks to the midwife and ignores Hagar in the situation.

Carita, for her part, narrates the birth itself dramatically because it was difficult for the baby to fit through and the midwives and doctors threatened to take a suction cup. She says:

And when we then decided to take it [suction cup], then there really came a lot of doctors. It was almost unpleasant because like all those people rolled in and then I lay down and felt that, yeah, what was happening now. Then came another midwife who jumped on my belly and one 
doctor, a gynaecologist, one paediatrician and one nurse. As they want to immediately check that it has gone well, the suction cup. (IF mgt 1994/55)

In her story, Carita dramatizes the events using strong words like "unpleasant" and explains how doctors rolled in and how the midwife jumped on her stomach. The birth itself she narrates as follows:

That's when I was not quite there and I yelled pretty much [laughter]. And so, and ... but then the boy finally arrives. They said he had then come easily with a suction cup, after all it was almost that he didn't fit. (IF mgt 1994/55)

Birth is described in few words and without drama ("but then he finally arrived"), while the situation just before birth is told very dramatically. The statement "he almost didn't fit" means that the next procedure would have been a caesarean section. The situation was thus "almost" a caesarean section. Dramatizing the experience with such "almost" events also occurs in the stories of other women: there was an "almost" suction cup, they "almost" gave birth to a toilet bowl, or "almost" fainted in the shower. These "almost" narratives are so-called close call stories and contain a clear tension between the complicating action and the subsequent resolution (Labov 2013: 226). In that respect, they are very similar to the narratives on which Labov developed the breakdown of the basic structure of the narrative. In Harlem, he studied stories based on young boys' own experiences. They dealt with the boys' lives on the streets of Harlem and described a relatively dangerous life that included violence and situations that could have gone badly. There are also situations in birth stories I researched that could have gone very badly. These parts can be seen as a way to dramatize events, but also as a way to show the listener that giving birth is hard work.

Emilia narrates about the effort phase and birth, and then goes on to tell about the sex of the child anecdotally:

And then I got to start straining him out but then I didn't have such severe labour pains yet, so I got that kind of... snuff [hormone in snuff form]. And that stage wasn't as painful for me. Maybe because you knew it was about to pass or hoped [laughs] at least that it would go faster in the end. Then when it was when the child had really arrived and I heard him scream and didn't see him, it felt pretty awful, I gave birth on all fours, so my husband, who was involved, said "guess, guess what?" [laughing] So, then I, I remember, became wildly angry, "Well, say now whether a girl or a boy has arrived" [laughing] or at least I thought, yes, I did say something angry [sighing]. (IF mgt 1995/73) 
The effort phase and the associated impatience that the situation is not progressing faster are described above. Emilia laughs as she says she hoped the birth would go faster. Birth is not really verbalized other than "when the child had actually arrived". Instead, a dialogue between Emilia and her husband on the gender of the child is described, with dramatizing elements such as sighing and direct quotes. Also, in the other women's stories you can find the transition from birth to dealing with the sex of the child. In her story, Carita explains the midwife's words, "So she took my hand and put her hand between Carl's [child's] legs and said, 'Look what kind of football player you've got now' [laughing]" (IF mgt 1995/45). Ingegärd, for her part, asks the midwife for the sex: “Which is it?' - 'I can't say yet,' said the midwife" (IF mgt 1995/80). The use of direct quotation results in women changing the tense in their narration and using the so-called historical present in a context where the imperfect is otherwise prevalent.

The women have been expecting to give birth and have prepared for childbirth. Yet they are almost amazed that the result is a child. Flora describes how the midwife asked her to feel her child's head in the effort phase: "So I felt a small soft slimy lump [laughing]. I thought, is this a small human head?" (IF mgt 1995/32) Flora is almost amazed that she really gives birth to a human. This astonishment is shared by many others, indicating that they are prepared primarily for childbirth and not for the birth of a child. The focus is thus more on action and process than on the outcome of childbirth. Gudrun's surprise is related to the child's appearance:

And then the midwife said now it shows its head and it has black hair... And then I remember that I went just like, WHAT? ... it was all wrong [a little laughing] but I hadn't had any picture of that baby, but I was still thinking of a three kilo bald baby, even though I hadn't thought of any facial features, or something... who it would resemble. But that was completely wrong, a big black-haired baby. (IF mgt 1995/75)

Women tell about birth by dramatizing the events around the birth itself. These include the pain of the opening phase, the slow progress of the birth in their opinion, and the hard work of the effort phase. The birth itself is presented in few words and relatively undramatically. Most often women just say what time it was when the child was born. It feels like the birth-givers do not really have any more to tell. Instead, it describes events related to the child - for example, the amazement that the child was born - as well as telling the child's gender and describing their appearance. The actual birth of a child into the world is seen as the result of hard physical labour. It is a relief for the mother if no complications have occurred. The moment of birth is also over relatively 
quickly. It is therefore logical that the story focuses on the child, its gender and appearance, or what it felt like when the child was born.

Childbirth manuals, counselling, and stories from other women do not provide narrative models for the narration of the moment a child is born, as the steps that precede this require more attention. The fact that the moment of birth is described only in few words does not diminish its significance, but rather shows how important the evaluation of events is for women. This is related to the individual experiential dimension of childbirth, which I address below.

\section{BIRTHGIVING AS EXPERIENCE}

\section{Individual experience and shared experiential knowledge}

The analysis of personal narration raises questions about the relationship between the concepts of individual experience (Erlebnis) and shared experiential knowledge (Erfahrung) (cf. Hovi 2007: 22). Individual experience means that a person is involved in an event, while experiential knowledge means awareness and knowledge contained in the experience. Experiential knowledge also includes individual experiences (O'Dell 2002: 20). I use the concept of individual experience as an interpretation of an event in which the interviewee has been involved and which has a beginning and an end. Meanings and expressions are given to this individual experience through linguistic means (Svalastog 1998: 29).

In the interviews, the mothers talk about their individual childbirth experience and interpret this event while expressing it in words. Individual experience, in turn, leads to experiential knowledge. The empty shell of the narrative is filled with individual, embodied experience and an evaluation of the events that are included in the experience and that form the starting point for the personal narrative. Evaluating and assessing an individual's experience highlights the narrator's perspective on the experience, demonstrates attitudes towards what happened, and expresses emotions (Labov 1972; Adelswärd 1996).

As I have already mentioned, the women I interviewed were specially prepared for the experience of childbirth. They had prepared, among other things, by reading the relevant literature and had high expectations specifically for childbirth. In their accounts, they compare their expectations with their experience. In some cases, expectations fit well with the experience, but some women also say that everything went differently than they had thought. The stories express expectations in different ways: "as I had thought", "as I had expected", "I thought", and "I had planned". Expectations and their fulfilment 
are also expressed more precisely if something during childbirth, such as pain, was "much harder ... than I could have ever imagined" (IF mgt 1995/32). Unfulfilled expectations are described by phrases like "so it didn't go exactly as planned" (IF mgt 1995/135). This could relate to the whole course of childbirth or to some individual procedure or event that the mother had hoped to avoid. Expectations may relate to the course of events in general, so that the mother can control both herself and the whole situation. Women also talk about their expectations about the hospital, such as the place of delivery and the quality of the pain, the fear of the need for premature effort, the desire to avoid epidural anaesthesia, but also the anticipation of the child and his or her appearance.

Supported by these expectations, the mothers built their story based on a plan of what the course of the birth should be like. Creating a more or less conscious plan was part of mental preparation for childbirth. Expectations show that there is an intertextual relationship between texts and ideas about childbirth (cf. Honko 1998: 33). In the birth story, the outline or mental text of this plan appears as the expectations described by the narrators. Expectations form the starting point or formula by which women narrate, although this is not uttered aloud.

A plan based on pre-conceptions would have allowed women to narrate childbirth-related events even before they had gone through their individual experiences. However, they could not have told in advance how they experienced childbirth or what it was like to become a mother. The dimension of the story's individual experience shows that they had positive expectations for childbirth. That is why they narrate events as birth-givers and not as new mothers. They were confused by the result of childbirth: the fact that they had a child. At some level, this became, of course, clear to them, but their preparation had not focused on the child but on childbirth. I can only make assumptions about why this is like that. Perhaps one reason is the notion of childbirth as a revolutionary peak experience that prevailed in the 1990 s and is still likely to prevail. The concept of peak experience was created by psychologist Abraham Maslow. It has been used to show positive events that fundamentally change an individual's way of perceiving themselves (Petri \& Cofer n.d.). There are strong positive emotions associated with peak experience. Such is the case, for example, with the feeling that extreme athletes experience after a demanding performance (Lassila 2007: 77). Thus, giving birth becomes an experience comparable to extreme sports. At the same time, the human need to be a unique individual and to invest in one's own life is satisfied (Bauman 2001: 172). 


\section{A fantastic or confusing experience?}

The women evaluated individual events throughout the story. In addition, half of the women present in their story a unified spontaneous assessment of their entire childbirth experience. In many cases, the assessment is at the end of the story, after the description of the birth itself. Evaluation is a reflection of the whole course of events with the starting point as the self, its understanding of the course of childbirth and its own contribution to it. As in Judith's story, in many cases a significant part of the end of the story is the evaluation of the experience presented by the mother. Judith describes the birth and then voluntarily evaluates both a few events and the experience as a whole:

And so the girl was born, at twenty to four in the afternoon. So, it didn't take an awful long time. So, that's how the course of events was, the course like how it went. And in my mind you react to it somehow, as you thought it would react, so that when you're in the middle of it, I didn't think so much that I did keep my head pretty cool [laughing] so that I could act even though it hurt, it did hurt. But that ... but then there were other things that could be forgotten that had just been imagined [laughing] about childbirth positions and more. It was like a secondary thing [in Finnish]. Then when you're in it ... That you can't then, I felt afterwards, then it feels like you couldn't imagine ... at all that yeah, yeah so I want to give birth hanging from a curtain rod [laughing] that it, it... Then there are other things that are more important, at least for me ... So that, so that it was now then a brief summary. (IF mgt 1995/102)

Above, Judith connects to her previous expectations of the duration of childbirth and her own reactions to pain and childbirth as a whole. For her, expectations were partly met and partly unfulfilled. Flora evaluates childbirth twice, and the latter evaluation concludes in the form of an elegant final summary:

But to be a first-time mother so it probably went terribly well, as if it was right... ideal childbirth, no complications or nothing like that ... So it was like that, so for me [sigh] it was kind of wild, such a great experience in every way. That I didn't have much like... those pains were of course one thing that was involved, but that it was yes indeed positive. That so-so it went. (IF mgt 1995/32)

Based on her pains, Flora estimated that hers had been an ideal birth. Dagmar, on the other hand, represents those who do not give a clear overall evaluation in their story. However, she explains her feeling of surrender during childbirth. 
Hagar's account is very reflective, and she ponders deeply about her role in an active childbirth. Certain women, such as Marta, did not evaluate their experience voluntarily, but did so only when I had specifically asked about it.

In their evaluations, women highlight different aspects of the experience. Ingegärd evaluates her experience spontaneously and positively: "So that, I don't know, I have a hugely positive experience of it all. That it was not ... I have never had such an idea of what I have begun, no, I won't do that again" (IF mgt 1995/80).

Emilia's assessment of the experience focuses on the duration of childbirth, which in her own perception took a long time. Konstance commented at the end of her story on the enormous fatigue she felt after the birth of the child. The experience of meeting the newborn child also appears in the assessments of some women. Among other things, Gudrun talks about how she felt the child really was a stranger. She compares the experience of giving birth to other great experiences of her life and proudly says about her performance in giving birth to a child:

It felt like... when there's something left behind when you've done something big. A bit the same feeling as when I received the school graduation certificate, an ever so solemn occasion, so now that I have achieved something, and just at that moment ever so happy. (IF mgt 1995/75)

Gudrun says she did not live through a "nirvana experience" that she had heard other women talk about. She also refers to her own mother's experience of childbirth and her ability to hold the reins in her hands during childbirth. Gudrun combines the expectations she has gained from other women's experiences and knowledge with her own assessment of her experience. Hagar also attaches to her assessment her expectations, especially her desire to be able to give birth actively and naturally. She estimates that she had thought it more difficult to have a child than she had experienced in the end. Stories often state that women are satisfied that they had "survived" childbirth. In these cases, the individual experiential dimension is on the surface, and women share their experiences as birth-givers rather than new mothers.

An emotional examination of childbirth is reflected, for example, in the assessment of pain. The experience is often seen as positive and joy-filled, but expressions of fear and confusion are also used. Anita says she was "happy, fearful of death and full of horror" (IF mgt 1993/22). Dagmar stands out from my interviewees because she expresses strong emotions when evaluating events. She says: 
I thought I couldn't stand it anymore, as if I wouldn't make it [almost crying], I didn't think at all that I had a child to give birth to, I just thought that, well now I'm about to die [laughing]. (IF mgt 1994/63)

Dagmar uses the Swedish term stryka med (perish), which can be thought of as a euphemism for death. At the same time, the quote again shows how childbirth is dominant and perceived as burdensome, and that the child remains secondary at this stage. Fear also emerges in contexts where women felt they did not control the situation they described. A good example of this is the previous quote from Dagmar's account, which uses soothing laughter.

In assessing the whole birth, Dagmar refers to another place and another time, the mythical time "before". She compares her own ability to women "who have given birth at home and who gave birth before and such" (IF mgt 1994/63). Gudrun also reflected on her situation by comparing it to a historical time, the beginning of the twentieth century, when women gave birth without medical technology. She is horrified by what would have happened then to her child, who was almost pulled out and whose clavicle broke as a result. This shocked Gudrun: "When I still think about it I am a little scared when I think that if I hadn't been giving birth in the twentieth century, how would I have done 100 years ago?" (IF mgt 1996/44)

The quotations above express the concern or fear that women felt about the situation and this is related to the perception of a "primitive" woman who gave birth without much effort. Folklorist Susanne Nylund Skog (2002: 63) presents the notion of a "mother giving birth in the middle of potato harvest", a woman who works in a field at harvest and unnoticed deviates from her job to give birth to a child. This perception, according to Nylund Skog, was still valid in the Scandinavian context in the 1990s. Despite high-tech hospitalization - or perhaps due to its impact - women compare their own ability to give birth to a mythical era, the "birth myths" they know, and exemplary narratives.

The examination of women's birth experiences shows in how many ways they evaluate and view the experience in the form of a narrative. Evaluation is one way to fill a story with meanings. Some women have a single evaluative section at the end of the story, while others have more fragmented comments. Relatively few women directly say the experience was good or bad. Some emphasize that childbirth was a fantastic experience, while others view it with mixed feelings. How big a part of the experiential dimension of childbirth in women's stories depends on women's attitudes toward childbirth? Those who hope for a normal birth focus on having a child and do not experience childbirth as a great experience. In contrast, those women who plan their childbirth in detail and become familiar with the literature in the field have strong opinions 
about how childbirth should go. They also have high expectations of the experiential dimension of childbirth, which is also reflected in their accounts. For these women, the experiential nature of childbirth is central.

Above, I showed that narration is largely form-bound, although women's experiences of childbearing differ and are largely unique. The narrative pattern can be seen in the narratives of all women, yet there are significant differences in the narrator's personality, in the amount of detail, dramatization, explanation, or how entertainingly they tell their stories in different types of interview situations. The story becomes the woman's own one, based on what kind of evaluation she makes, how she dramatizes events, and what message she wants to convey in her story. Finally, I consider the meanings of the birth story, its idea, and the meanings of experience and telling.

\section{CONCLUSION: POINTS OF EXPERIENCE AND NARRATIVE}

I have demonstrated above how evaluation expresses the narrator's perspective on experience, which shows their attitudes and creates ways to express their emotions. With this evaluation, the narrator emphasizes the point of the story. Laughter, the use of direct quotes, and anecdotes also denote the point of the story (Bauman 1986; Kaivola-Bregenhøj 1988). But what does the story deal with on a deeper level? What message does the first-time birth-giver transmit in her account of childbirth, obstetric care, and herself as a birth-giver?

The key message in these narratives is that new mothers show that they have survived the giving birth to a child. Childbirth may have been perceived as more difficult or easier than expected, but they still managed to do it. It is an accomplishment that mothers tell about with joy and pride. In their stories, women address the experience and describe it in a consistent format, emphasizing their own action. They tell about themselves as birth-givers who have endured childbirth and thus become part of the maternal community. Their stories deal with women's identities as women, birth-givers, and new mothers.

The experience of giving birth is central to the story. Even those women whose experience was not ideal unexpectedly share their experiences, building a happy-end version. They can deal with this story and live with it. They turn a negative event into a positive one as if to correct what happened (Lehmann 1978). The stories deal with the birth self, which strengthens identity as both a woman and a birth-giver. They also create a part of the life story.

In general, the providers of my material were satisfied with the obstetric care received. It was essentially adapted according to the wishes of the mother 
to natural or conventional childbirth. However, the stories involve tacit criticism of the hospital. This comes to the fore when women talk about weak autonomy and helplessness in the hospital machinery, the difficulty of getting their wishes forward, and the reluctance of the hospital staff to fulfil their aspirations. The feeling of being at the mercy of others also contributed to the fact that the woman might not have wanted or dared to express her wishes. The birth-giver was at a disadvantage in relation to the trained staff. The stories also address the fact that high expectations were not met and that the women felt tortured, suffered, and were insecure about both the course of childbirth and their own role in it. Confused laughter shows that pain and other bodily reactions were central parts of the experience. At the transition level, there is also existential fear in the narratives. However, the message of the stories is also the happiness experienced since the birth of the child, which the women expressed enthusiastically and proudly.

Those women whose births went as expected presented hero stories. In them, proudly and dramatically using, among other things, a laugh-reinforcing element, they talked about things that "almost" happened - but in the end everything went tremendously well. The experiential dimension is strong in the narrative and puts the actual birth-giver at the centre. Birth becomes the culmination of the story. This is reflected in the fact that postnatal events are described in a temporal and local vacuum, and they form the anti-climax of the narrative rather than its climax. The story deals more with childbirth than with the birth of a child. Psychologically oriented researchers emphasize that a mother may not feel like a mother when she is still giving birth. Rather, it is a matter of process, and the woman who has given birth to a child gradually becomes a mother (Stern 1999). Women have high expectations, and childbirth as well as childbirth experience is important to them. In contrast, they are less prepared for motherhood on both an emotional and practical level. Some stories do not elicit any actual message or point. In this case, the narrative itself, the detailed description of the events, becomes the main idea.

The narrative shapes a wide range of key points. According to Viveca Adelswärd (1992, 1996), a researcher in speech communication, they have, first of all, an anecdotal point, where the idea is to tell a good story in itself. Women's stories are mostly very entertaining to listen to. This is also shown by the large amount of the narrator's amused laughter intertwined with the narrative. Often women put themselves in a comic position and thus laugh at themselves as well. Secondly, Adelswärd talks about points of embedded values. These reflect women's views of pain, corporeality, femininity, and childbirth as an embodied experience. Women's stories describe the values associated with childbirth, the movement between natural and medical childbirth. Indeed, 
women approach their births differently in their accounts. They emphasize safety and not question hospitalization but do give both praise and reproaches to obstetric care. The stories also reflect women's relationship to their bodies. They are stories of power, control, intuition, and knowledge. They highlight the norms of Finland's ideal birth in the 1990s, where naturalness is at one end of the scale and the possibility of choosing interventions at the other. The story illustrates how giving birth to a child is seen as part of the formation of femininity and sex-related values. Women talk about these things ironically, critically, and bitterly but also with humour, enthusiasm, and pride.

Thirdly, the narratives describe the narrator's goal to create coherence in the narrative. Women narrate childbirth both as birth-givers and as women. There are norms associated with both childbirth and femininity. The notion of a "proper" childbirth is on the line between refusing medical intervention on the one hand and avoiding suffering on the other. Women talk about childbirth as performance: you must be determined and cope with childbirth, which for some means coping without pain relief and for others coping with childbirth as such. The narrator can depict a difficult experience with self-pity. In their stories, however, most women translate their experiences into one that they not only survived but coped well with. At the same time, the birth itself remains in the story a matter that is depicted in a few words and no emotions at all: "but then the boy finally arrived".

\section{NOTES}

1 I conducted the interviews myself and, while gathering this material, ethical questions were especially important to me. Maintaining the anonymity of the interviewees was vital, and no one can be identified from the interviews. I made a contract with each woman to use the interviews. I have examined my interview material in my doctoral thesis in folkloristics, Berättelser om barnafödande: Form, innehåll och betydelse $i$ kvinnors muntliga skildring av födsel (Marander-Eklund 2000). The main aim of the doctoral thesis was to study how first-time mothers articulate their corporeal childbirth experiences in their childbirth narratives. I kept in touch with the mothers and told them about the progress of the research. The women have had a chance to study the portraits of the mothers in my doctoral thesis and approve their contents. The material is archived in Cultura, the Åbo Akademi University Folklore Archive. This article is translated and proofread by Jorma and Maria Vatanen.

${ }^{2}$ For my doctoral thesis I conducted recurrent interviews of which the first one was made before the birth, the second one soon after the birth, and the third one a year after the birth. The aim was, on the one hand, to study women's expectations about childbirth and, on the other hand, to compare two different variants of a childbirth narrative. In this article, I am not studying the pre-conceptions nor do I compare variations with each other. Instead I focus on the stories, described soon after the 
birth. These interviews were carried out in the interviewees' homes 3-4 weeks after the child was born. During the first interview we had become acquainted with each other which had, in my opinion, a positive influence on our interaction in the second interview.

\section{ARCHIVAL SOURCES}

Turku, Åbo Akademi University, Cultura Folklore Archive: IF mgt 1993/22

IF mgt 1994/55, 60, 63, 66

IF mgt 1995/32, 45, 73, 75, 77, 80, 102, 130, 135

IF mgt 1996/1, 23, 44

\section{REFERENCES}

Adelswärd, Viveca 1992. Den första älgen. Om strukturen i en typ av narrativ. [The First Elk: About Narrative Structure.] In: Staffan Hellberg et al. (eds.) Svenskans beskrivning, Vol. 19. Lund: Lund University Press, pp. 62-72.

Adelswärd, Viveca 1996. Att förstå en berättelse: eller historien om älgen. [Understanding a Narrative - or the Story of the Elk.] Stockholm: Bromberg.

Arvidsson, Alf 1999. Folklorens former. [The Forms of Folklore.] Lund: Studentlitteratur. Available at https://www.academia.edu/34681003/Folklorens_Former_2.pdf, last accessed on 12 October 2020.

Bauman, Richard 1986. Story, Performance, and Event. Contextual Studies of Oral Narrative. Cambridge: Cambridge University Press. https://doi.org/10.1017/ CBO9780511620935.

Bauman, Zygmunt 2001. Det individualiserade samhället. [The Individualized Society.] Uddevalla: Daidalos.

Fjell, Tove Ingebjørg 1998. Fødselens gjenfødelse: Fra teknologi til natur på fødearenaen. [Rebirth of Birth: From Technology to Nature on the Birth Arena.] Kristiansand: Høyskoleforlaget.

Fjell, Tove Ingebjørg \& Hagström, Charlotte \& Marander-Eklund, Lena \& Nylund Skog, Susanne (eds.) 1998. Naturlighetens positioner: Nordiska kulturforskare om födsel och föräldraskap. [Positions of Naturalness: Scandinavian Cultural Researchers on Birth and Parenthood.] Åbo: Nordiskt nätverk för folkloristik.

Giddens, Anthony 1995. Intimitetens omvandling: Sexualitet, kärlek och erotik $i$ det moderna samhället. [The Transformation of Intimacy: Sexuality, Love and Eroticism in Modern Societies.] Nora: Nya Doxa.

Gissler, Mika \& Toukomaa, Henri \& Virtanen, Martti 1996. Perinatalstatistik 1995. [Prenatal Statistics.] Helsinki: Stakes.

Hänninen, Sisko-Liisa 1965. Kätilötyön vaiheita. [Phases in Midwifery.] Helsinki: Otava. 
Helsti, Hilkka 1995. Raskaus ja synnytys parin sukupolven takaa. [Pregnancy and Childbirth Two Generations Ago.] In: M. Sorvettula (ed.) Naisen terveys: Hyvän elämän strategiset mitat. Helsinki: Kirjayhtymä, pp. 145-178.

Herman, David 2009. Basic Elements of Narrative. New Jersey: John Wiley \& Sons.

Hirdman, Yvonne \& Bohman, Kristina \& Rörslett, Maj Birgit 1995. Påminnelser: om kvinnors liv $i$ Sverige. [Reminders: About Women's Life in Sweden.] Stockholm: Carlsson.

Hollmen, Arno \& Jouppila, Riitta \& Työläjärvi, Riitta 1987. Synnytyskivun lievityksen kehitys ja nykytila Suomessa sekä tulevaisuuden haasteet. [Developing Pain Relief during Birth in Finland.] Suomen lääkärilehti, Vol. 42, pp. 1158-1164.

Honko, Lauri 1998. Att synliggöra textualiseringsprocessen. [Making the Process of Textualisation Visible.] Tradisjon: tidsskrift for folkeminnevitskap, Vol. 1, pp. 33-41.

Hovi, Tuija 2007. Usko ja kerronta: Arkitodellisuuden narratiivinen rakentuminen uskonliikkeessä. [Belief and Narration: The Narrative Construction of Everyday Reality in the Faith Movement.] Elore, Vol. 14, No. 1, pp. 1-4. Available at https://journal.fi/elore/article/view/78636/39535, last accessed on 12 October 2020.

Jordan, Brigitte 1993 [1978]. Birth in Four Cultures. A Cross-Cultural Investigation of Childbirth in Yucatan, Holland, Sweden and the United States. Revised and expanded by Robbie Davis-Floyd. Long Grove, Illinois: Waveland Press, Inc.

Kaivola-Bregenhøj, Annikki 1988. Kertomus ja kerronta. [Narrative and Narrating.] Helsinki: Suomalaisen Kirjallisuuden Seura.

Kivivirta, Louise \& Vehviläinen-Julkunen, Katri \& Lauri, Sirkka \& Callister, Lynn Clark 1994. Eri kulttuureissa elävien naisten kokemuksia synnytyksestä ja äitiydestä. [Experiences of Birthgiving and Motherhood by Women from Different Cultures.] Turku: Turun kaupunki.

Klemettilä, Sinikka 1996. Kymmenen vuotta aktiivista synnytystä. [Ten Years of Active Birth Giving.] Vauva, No. 2, p. 28.

Klintberg, Bengt af 1986. Råttan i Pizzan: folksägner $i$ vår tid. [The Rat in the Pizza: Legends of Our Time.] Stockholm: Norstedt.

Koivu, Leena (ed.) 1982. Syntymä: Enteitä ja uskomuksia. [Birth: Omens and Superstitions.] Helsinki: Suomalaisen Kirjallisuuden Seura.

Koskinen-Koivisto, Eerika 2013. A Greasy-Skinned Worker - Gender, Class and Work in the 20th-Century Life Story of a Female Worker. Jyväskylä: University of Jyväskylä. Available at https://jyx.jyu.fi/bitstream/ handle/123456789/42505/978-951-39-5517-5_2013.pdf?sequence=1\&isAllowed=y, last accessed on 12 October 2020.

Labov, William 1972. Language in the Inner City: Studies in the Black English Vernacular. Philadelphia: University of Pennsylvania Press.

Labov, William 2013. The Language of Life and Death: The Transformation of Experience in Oral Narrative. Cambridge: Cambridge University Press.

Lassila, Janina 2007. Vår tids och vår kulturs gränstänjning - en studie om extremsportutövarens jaggestaltning. [Pushing Boundaries of Our Time and Our Culture - A Study of the Extreme Sportsman's Self-Management.] In: Anna-Maria Ånäs \& Janina Lassila \& Ann-Helen Sund \& Lotta Wessberg (eds.) Extremt? Etnologiska analyser av kvinnorock, extremsport och Ultimate Fighting. Turku: Åbo Akademi, pp. 53-182. 
Lehmann, Albrecht 1978. Erzählen eigener Erlebnisse im Alltag. Tatbestände, Situationen, Funktionen. Zeitschrift für Volkskunde, Vol. 74, No. 2, pp. 198215. Available at https://www.digi-hub.de/viewer/image/DE-11-001938277/554/ LOG_0200/, last accessed on 14 October 2020.

Marander-Eklund, Lena 2000. Berättelser om barnafödande. Form, innehåll och betydelse $i$ kvinnors muntliga skildring av födsel. [Narratives of Childbirth: The Form, Content and Meaning in Women's Oral Depiction of Birth.] Diss. (PhD Thesis). Turku: Åbo Akademis förlag.

Marander-Eklund, Lena 2002. Narrative Style: How to Dramatize a Story. Arv: Nordic Yearbook of Folklore, Vol. 58, pp. 113-123.

Marander-Eklund, Lena 2008. Narrative and Emotions: Revealing and Concealing Laughter. Folklore: Electronic Journal of Folklore, Vol. 39, pp. 95-108. http:// dx.doi.org/10.7592/FEJF2008.39.eklund.

Marander-Eklund, Lena 2014. Att vara hemma och fru: En studie av kvinnligt liv $i$ 1950-talets Finland. [Staying at Home and Being a Wife: A Study of Woman's Life in the 1950s Finland.] Helsingfors: Svenska litteratursällskapet i Finland. Available at https://www.sls.fi/sv/utgivning/att-vara-hemma-och-fru, last accessed on 14 October 2020.

Mattsson, Kristin 1998. Från värkar till sammandragningar: Olika sätt att tala om graviditet och förlossning. [From Labour Pain to Contractions: Different Ways of Talking about Pregnancy and Childbirth.] In: Harriet Silius \& Ann-Catrin Östman \& Kristin Mattsson (eds.) I dialog med kvinnoliv. Turku: Åbo Akademi, pp. $165-188$.

Miettinen-Jaakkola, Aila 1992. Nainen naiselle: Luonnollinen syntymä. [From Woman to Woman: Natural Birth.] Helsinki: Kääntöpiiri.

Nätkin, Ritva 1997. Kamppailu suomalaisesta äitiydestä: Maternalismi, väestöpolitiikka ja naisten kertomukset. [The Struggle of Finnish Motherhood: Maternalism, Population Politics and Women's Stories.] Helsinki: Gaudeamus.

Nylund Skog, Susanne 1998. Den ideala förlossningsupplevelsen: Tre kvinnors berättelser om barnafödande. [The Ideal Birthgiving Experience: Three Women's Stories about Childbirth.] In: Tove Ingebjørg Fjell \& Charlotte Hagström \& Lena Marander-Eklund \& Susanne Nylund Skog (eds.) Naturlighetens positioner. Nordiska kulturforskare om födsel och föräldraskap. Åbo: Nordiskt nätverk för folkloristik, pp. 97-114.

Nylund Skog, Susanne 2002. Ambivalenta upplevelser \& mångtydiga berättelser: En etnologisk studie av barnafödande. [Ambivalent Experiences and Ambiguous Narratives: An Ethnological Study of Childbearing.] Stockholm: Stockholms universitet.

Oakley, Ann 1993. Essays on Women, Medicine \& Health. Edinburgh: Edinburgh University Press.

Öberg, Lisa 1996. Barnmorskan och läkaren: Kompetens och konflikt $i$ svensk förlossningsvård 1870-1920. [The Midwife and the Doctor: Competence and Conflict in Swedish Childbirth Care 1870-1920.] Diss. (PhD Thesis). Stockholm: Ordfront.

O’Dell, Tom 2002. Upplevelsens lockelser, tingens dynamik. [Enticement of Experience, Dynamics of Things.] In: Tom O'Dell (ed.) Upplevelsens materialitet. Lund: Studentlitteratur, pp. 11-34. 
Odent, Michel 1986. Luonnonmukainen synnytys: onnellinen ja turvallinen menetelmä äidin ja lapsen parhaaksi. [Birth Reborn: A Happy and Safe Method for the Benefit of Mother and Child.] Jyväskylä: Gummerus.

Petri, Herbert L. \& Cofer, Charles N. n.d. Motivation. Applications in Society. Britannica. com. Available at https://www.britannica.com/topic/motivation/Applications-insociety, last accessed on 12 October 2020.

Saarikoski, Seppo 1994 [1992]. Synnytysopin perusteet. [Introduction to Obstetrics.] 2nd ed. Tampere: Legekustannus.

Salmenmaa, Virpi 1998. Synnytyksen hoitokäytäntö Suomessa. [Clinical Practice of Birthgiving in Finland.] Tidskrift för barnmorskor, No. 2, pp. 12-13.

Salmi, Lauri 1994. Perheen lapsiluvun suunnitteluun vaikuttavat tekijät: Tutkimus turkulaisista naisista. [Factors Influencing the Planned Number of Children: A Study of Turku Women.] Turku: Turun yliopisto.

Saresma, Tuija \& Ruotsalainen, Erja 1998. Synnytyspelot ovat yhä vaiettuja ja vähäteltyjä. [Fears of Birthgiving Are Still Silenced and Belittled.] Anna, Vol. 36, No. 20 , pp. 56-60.

Schoultz-Ekblad, Birgitta 1988. I livets tjänst: Ett historiskt sökande av barnmorskans paradigm under tiden 1896-1970. [In the Service of Life: A Historical Search for the Midwife's Paradigm during the Period 1896-1970.] Helsinki: Helsingfors svenska sjukvårdsinstitut.

Stahl, Sandra 1977. The Oral Personal Narrative in Its Generic Context. Fabula, Vol. 18, pp. 18-39. http://dx.doi.org/10.1515/fabl.1977.18.1.18.

Stern, Daniel N. 1999. En mor blir till: Hur moderskap förändrar dig för all framtid. [Birth of a Mother: How Motherhood Changes You Forever.] Stockholm: Natur och Kultur.

Suonio, Sakari \& Vartiainen, Heikki \& Laasanen, Tuula \& Saarikoski, Seppo 1993. Synnyttäjän yleiset ja synnytykseen liittyvät pelot. [Anxiety among Birthgivers.] Suomen Lä̈̈kärilehti, Vol. 32, pp. 3133-3138. Available at https://www.laakarilehti. fi/tieteessa/alkuperaistutkimukset/synnyttajien-yleiset-ja-synnytykseen-liittyvatpelot/, last accessed on 14 October 2020.

Svalastog, Anna Lydia 1998. Det var ikke meningen ... Om konstruksjon av kjønn ved abortingrep, et feministteoretisk bidrag. [I Didn't Know... Induced Abortion and the Process of Gender Construction, a Theoretical Feminist Contribution.] Diss. (PhD Thesis). Uppsala: Uppsala universitet.

Tillhagen, Carl-Herman 1983. Barnet $i$ folktron: tillblivelse, födelse och fostran. [The Child in Folk Belief: Creation, Birth and Education.] Stockholm: LT förlag.

Tillhagen, Carl-Herman 1985. Konsten att skaffa sig vackra barn. [The Art of Making Beautiful Children.] Stockholm: LT förlag.

Vi väntar barn 1995, 1997. [We Are Expecting a Baby.] Helsinki: Stakes.

Wessman, Vilhelm Eliel Viktorinus (ed.) 1952. Finlands svenska folkdiktning. [The Folklore of Swedish Finland.] VII. Folktro och trolldom. 3. Människan och djuren. Helsinki: Svenska Litteratursällskapet. Available at http://folkdiktning.sls.fi/\#/ publication/47/cover/, last accessed on 14 October 2020.

Wrede, Sirpa 1998. "Hon är inte en i hopen": Barnmorskor som publicerar minnen. [She Wasn't One in the Huddle: Midwives' Published Memories.] In: Harriet Silius \& Ann-Catrin Östman \& Kristin Mattsson (eds.) I dialog med kvinnoliv. Åbo: Åbo Akademi, pp. 112-142. 
Lena Marander-Eklund is Professor in folkloristics at Åbo Akademi University in Turku, Finland. Her research interests are narratives and narration, methodological aspects of interviews and questionnaires, life stories, emotions, weather folklore and folk medicine.

lena.marander-eklund@abo.fi 


\title{
THE RITE OF MALE CIRCUMCISION AMONG THE MUSLIM POPULATION IN THE WESTERN BALKANS
}

\author{
Alexander Novik \\ PhD \\ Head of the Department of European Studies \\ Peter the Great Museum of Anthropology and Ethnography (Kunstkamera) \\ Associate Professor \\ Saint Petersburg State University, Russia \\ njual@mail.ru
}

\begin{abstract}
The article deals with the rite of circumcision among the Muslims in the Western Balkans, one of the most widespread ritual practices, held with some variations mostly at the age of 3 to 7 . The tradition that never gets explicitly brought up in the sacred text of the Quran has become practically mandatory. Among the rites of passage, circumcision is considered by Muslims a significant act, as it symbolizes the transition from the status of a child to the status of an adult who has all the rights of a "full-fledged" man. In the Balkan Muslim community, an uncircumcised man is regarded as an exception to the rule.

In the second half of the twentieth century, the technical side of the rite was radically changed, but it has not affected its sacred and traditional elements. Nowadays, in its origins, its religious roots, its folk depictions and its place in the relations between "us" and "them", the circumcision ceremony is a rite of initiation and is one of the most remarkable ritual practices that demonstrates committal to Islam. The article is mainly based on the actual field data gathered by the author in Albania, Kosovo, North Macedonia, Montenegro, and other countries of the region during the last three decades.
\end{abstract}

Keywords: Albanians, Balkan Muslims, beliefs, circumcision, customs, folk Islam, folk medicine, innovations, interpretations of traditions, rites of passage, ritual practices

\section{INTRODUCTION}

For a long time circumcision has been one of the most persistent ritual practices among many peoples of the world. Representatives of particular religions - first of all, Jews and Muslims - do not consider the rite of circumcision one of the main conditions of accepting the fundamentals of the faith (though, for example, 
the text of the Quran does not explicitly mention the necessity of circumcision for a righteous Muslim) (The Noble Qur'an; Denny n.d.). On the Balkan Peninsula, circumcision spread widely due to the Ottoman invasion and the local ethnic groups' conversion to Islam in the fourteenth-seventeenth centuries. Currently, the Balkan people view this rite not just as a sign of adherence to Islam, but also as a part of tradition, a rule established by their ancestors and therefore mandatory (Xhagolli 2008: 21-37).

The aim of the current study is to analyze the perception of the rite of circumcision by the peoples of the Western Balkans, particularly the Albanians of Albania, Kosovo and North Macedonia, with data from other ethnic groups (predominantly Muslims as well as Orthodox and Catholic Christians). It is very important, in my opinion, since over the last few decades there has been an increase of influence of the radical forms of Islam, with attempts of spreading the practices that are not traditional for the Balkan regions, such as female circumcision. I am focusing on male circumcision, which is considered a traditional practice in the Balkans - as opposed to the foreign rules and stereotypes introduced from the outside (cf. Elbasani \& Roy 2015).

The rite of circumcision is one of the main rites of passage that symbolize the transfer from the status of a child to the new status of an adult (in this case, of course, it is a matter of confessional rather than biological age). The boy's initiation marks the border between childhood and adult life - the rite signals that the Muslim community has just become bigger and now has a new member (Çoçaj 2012: 15-17).

So far there have been no studies on this particular topic (except for the few papers dedicated to details of the festivities surrounding the rite). Together with Yefim Rezvan, we have developed a pilot project of research of Islam in the Balkans, which also includes the topic of circumcision (Novik \& Rezvan 2019: 119-153). The main goal of the project is the study of beliefs and ritual practices of the so-called folk Islam (other term: popular Islam) with the aim of discerning mechanisms of preserving and passing on traditions in the spiritual and material spheres of people's life.

This study is mainly based on the fieldwork I carried out in the Western Balkans in 1990-2019, as well as the analysis of ethnographic, folklore, and historic records preserved in the archives of the Institute of Cultural Anthropology and Art Studies (Tirana), the Institute of Linguistics and Literature of the Academy of Sciences of Albania (Tirana), and the Institute of Albanian Studies (Pristina). The main methodological principles underlying the study are the descriptive, typological, and comparative approaches. The principal methods employed here are structural and functional analyses. A historical approach allowed me to reveal the main strands of the genesis of the circumcision custom and the evolution of the old ritual practice until today. 


\section{HISTORICAL AND THEORETICAL OVERVIEW OF THE TOPIC}

The circumcision of an orthodox Muslim (khitan, Arabic: ختخ; khatna, Arabic: Tتخ; sunnat - an Islamic term for circumcision) is one of the main demands of Islamic teaching in most of the world's region (Wensinck 1986: 20-22). In the modern practices of the Balkan peoples this religious custom is observed almost unfailingly.

In human history, we can find very early instances of the circumcision practice (Gennep 2004 [1909]: 69-72). There are different versions of the practice's origins, which usually explain the practical significance of the procedure from the hygienic aspect. This operation involves the surgical removal of the foreskin from the male genitals, which leaves the head open (Circumcision n.d.). The absence of the foreskin contributes to the cleanliness and does not demand as much care for the penis as in the case of uncircumcised men. According to various authors, this fact has contributed to the tradition of circumcision spreading among different peoples at the early stages of human history.

On the other hand, many anthropologists claim that the practice has been established not because of hygienic cleanliness, but in accordance with the ideas of religious cleanliness - the openness of genitals, in the opinion of priests and others who had "the connection to higher powers", led to the openness in the conversation with gods (Xhagolli 2008: 21-37).

We can give a great deal of examples of the tradition of circumcision in the past and present (Gennep 2004 [1909]: 69-72). However, we cannot discern any general tendencies. In any case, both main versions of the origin of circumcision have their weak points as well as strengths. For example, not all peoples of the world have this tradition, which means that circumcision is not a definite cultural, civilizational, religious or social universal. History has recorded cases when peoples who have practiced circumcision for a long time later give up the tradition (for example, the Armenians, who had practiced it as far as the end of the first millennium AD) (Karpov 1996), while others, on the contrary, acquire this tradition as an innovation, dictated by religious demands or matters of cleanliness and hygiene - anyway, it is an influence of factors of social fashion, which sometimes changes traditional institutions, lifestyles, and customs.

Different religions of the world have different approaches to circumcision.

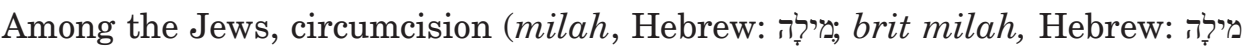
, li: literally 'testament of circumcision') is one of the main rites of initiation to the faith (Oren (Nadel') \& Prat 1992). In Christianity circumcision is neither a mandatory nor a recommended rite (though the Christian church calendar has the feast of Circumcision of Christ ${ }^{1}$ ). In most of the schools of Islam circumci- 
sion is a mandatory rite. In Hinduism, circumcision has not been recorded. For Buddhists, circumcision is optional - the religious teachings do not demand it.

In the modern world, many peoples in the Old as well as in the New World have adopted circumcision as a tribute to the demands of medicine, new fashions, and tendencies in cleanliness. ${ }^{2}$

Currently, the situation with circumcision practice, in accordance with religious and medical demands, is different worldwide: for example, there are countries and territories where 99.8-99.9 percent of men are circumcised (Afghanistan, Tunisia, Morocco, the West Bank, the Gaza Strip); by way of comparison, in Russia 11.8 percent of men are circumcised (for statistics on male circumcision in 237 countries and territories of the world, as of April 2016, see Novik \& Rezvan 2019: 122).

As mentioned above, circumcision has religious significance among the Muslims. In the opinion of most of the Muslim spiritual leaders, circumcision opens the believer's path to Allah. However, it is important to remember that Sunnah first appeared almost fourteen centuries ago, on territories with hot climate and limited water resources, and at that time maintenance of physical cleanliness simply guaranteed survival in the desert. This is why both the Quran and the Muslim sacred tradition fairly often refer to the topic of cleanliness - physical as well as spiritual. ${ }^{3}$

\section{CIRCUMCISION RITE IN THE BALKANS: THE POWER OF TRADITION AND/OR A SYMBOL OF FAITH}

The Muslims of the Balkan Peninsula practically unfailingly observe the instruction to perform the rite of circumcision - it is viewed by the majority as the act of adopting Islam (here we are talking about the views of the folk Islam - the beliefs and practice spread among the general public). Circumcision is one of the main rites of passage, held usually at the age of 3 to 7 with some variations (Gennep 2004 [1909]: 69-72; Xhagolli 2008: 21-23), during which a boy is transferred from the condition of uncertainty (first of all, confessional uncertainty) to the world of adult Muslim men-believers. This event is so significant in Islam that many peoples of the Balkan Peninsula view it as one of the main events in human life. In Albanian, the circumcision rite is called dásma e vogël 'little wedding', which is a sign of the event's high status not just from the religious standpoint, but also from the social one, for a large circle of relatives and acquaintances, often from the entire $f s^{4}$ and krahina ${ }^{5}$. A sumptuous ceremony is hosted for that occasion, with invitations for the numerous relatives, neighbors, friends, etc. Traditionally it has been a rite to which the 
imam or the mullah is invited. After the completion of the circumcision, there is a generous feast for the guests, where the menu is as carefully arranged as the dishes for an "adult" wedding. Often the guests take a ride around the town or the countryside: a cavalcade of cars, decorated for such an important and happy occasion, goes around the neighborhood to the sound of horns and loud music, to let the countrymen know that the Muslim community has grown another man has become a full-fledged member of the Islamic society, and the belief in Allah lives on (Novik \& Rezvan 2019: 125).

The family begins to prepare for the circumcision ceremony in advance besides the cooking and the invitation of relatives and friends, a special set of clothes - the so-called "sultan's attire" - is bought to the boy who is going to be circumcised (see Fig. 1). It consists of a wide shirt, wide trousers, a cloak and an essential head-dress with a plumage. This tradition is relatively new in the Balkans; it has become widespread in the last 30 years.

Figure 1. Showcase of a children's clothing store with a costume for the rite of circumcision. Ferizaj, Kosovo. Photograph by Alexander Novik, August 2011.

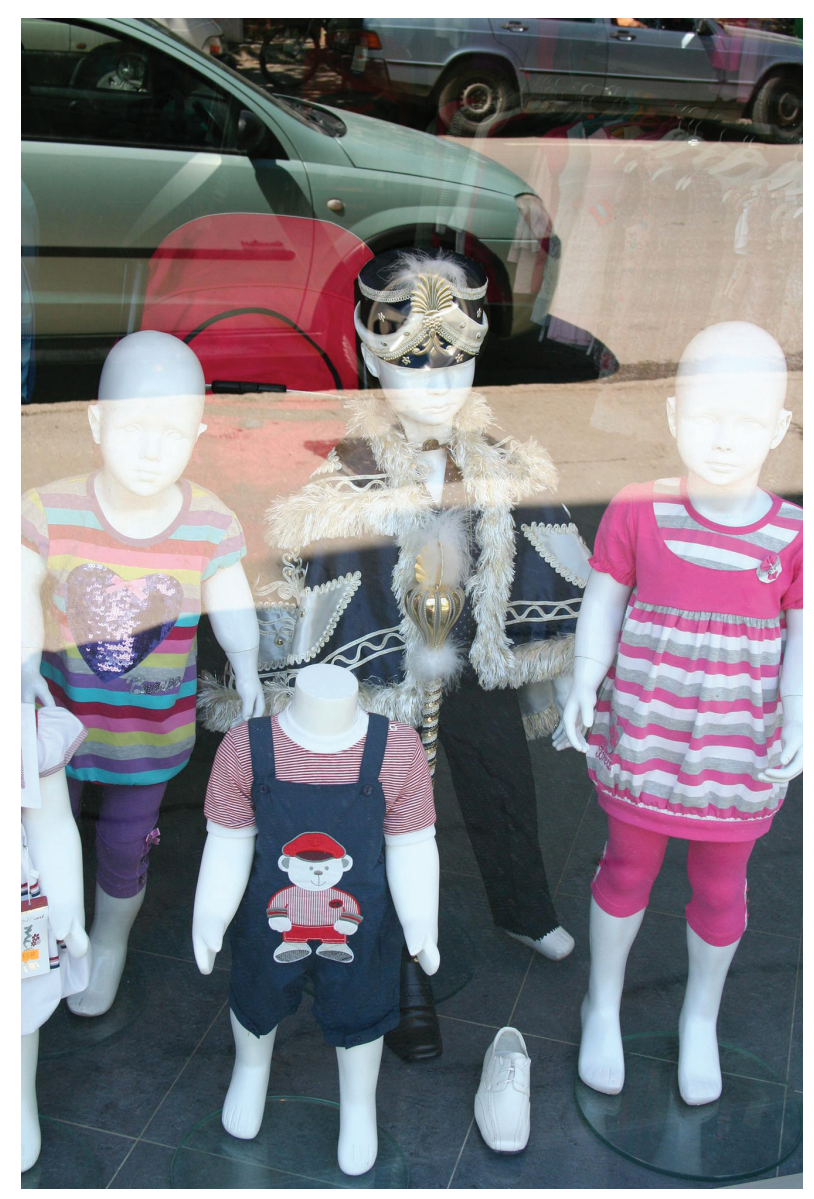


The age at which boys undergo the circumcision rite varies across South-Eastern Europe. There are no specific regulations on that subject as long as an adult Muslim man is circumcised. In modern Turkey circumcision is performed on infant boys - practically in the first months or often days of their life (the same practice is recorded in the Western countries, where the operation is viewed as a medical and hygienic necessity rather than a religious ceremony). In Albania, Kosovo, North Macedonia, Bosnia and Herzegovina, Serbia, Montenegro, and Bulgaria circumcision can be performed on boys under ten - when the ceremony gets performed at an older age, it is viewed by the others as late (the medical data should also be taken into account here: the child's body is already maturing and reacts more painfully to the operation). On rare occasions the parents delay the ceremony, and the grown children, out of their fear of surgery, flatly refuse it. A young man who remains uncircumcised would later hide the fact from his equals in age and the broader audience rather than announce it (Xhagolli 2008: 30-35).

In Albania, Kosovo, North Macedonia and other countries the ceremony of circumcision is usually performed when boys reach the age of 3-7 years. When a family has several sons close in age, the parents would frequently circumcise them all on the same day - this way, they save money on organizing the feast for the guests invited for the occasion (such feasts can sometimes bring ruin to people with a small income) (AMAE: Novik 2013; Novik 2017: 126-127).

Till the middle of the twentieth century, the circumcision ceremony was performed by imams, mullahs or khojas in villages and towns. As a rule, experienced religious workers, who had skills in conducting such operations, were asked to do it. They had the appropriate instrument - a well-sharpened knife, a straight razor or a special blade. These instruments were used exclusively for the operations that held a sacral meaning. For the treatment of the wounds the religious workers also used the medicines (brewed herbs, salves, etc.) and available materials (tissues, bandages, garters) that they were accustomed to and that were approved traditionally. In Bosnia and Herzegovina, for example, in Sarajevo, for several decades after the Second World War circumcision was still performed by barbers (Serbian, Croatian, Bosnian, Montenegrin: бépбер / bérber < Turkish: berbér). The performance of the operation was part of their professional skills and brought them virtually more money than the rest of their job. As the long-present trade system of the city collapsed, the berbers retained their establishments, getting a steady income for this procedure (Novik \& Rezvan 2019: 127).

In Albania, during the years of the communist dictatorship, which is here called the period of monism, conducting religious ceremonies was strictly forbidden. However, circumcision was performed "secretly" - not as a ceremony 
demanded by belief in Allah, but as a medical operation motivated by hygienic concerns. Boys were circumcised by surgeons in hospitals under the guise of "medical necessities", and at home the parents of the newly circumcised made a feast for their relatives and close friends, whom they trusted not to give them away to the authorities for a covered-up performance of a Muslim ceremony.

During the past decades, since the 1980s, circumcision operation has been performed in medical establishments in most Balkan countries. There are applications to surgeons in private as well as in public clinics. Nowadays one of the most frequently encountered advertisements in Kosovo is the announcement that this or that hospital or private clinic performs circumcision (Fig. 2). In most cases the boy is brought to the hospital by his parents (usually the father and one of the relatives). The surgeon operates using medical instruments and local anesthesia (painkiller injections, etc.). No prayers are said in this case (and the surgeon does not even necessarily need to be a Muslim). After the operation the surgeon swabs the wound with an antiseptic salve (most often it is brilliant green) and gives the parents recommendations for its treatment for the first days or weeks after circumcision. The family returns home and hosts a celebration for friends and relatives.

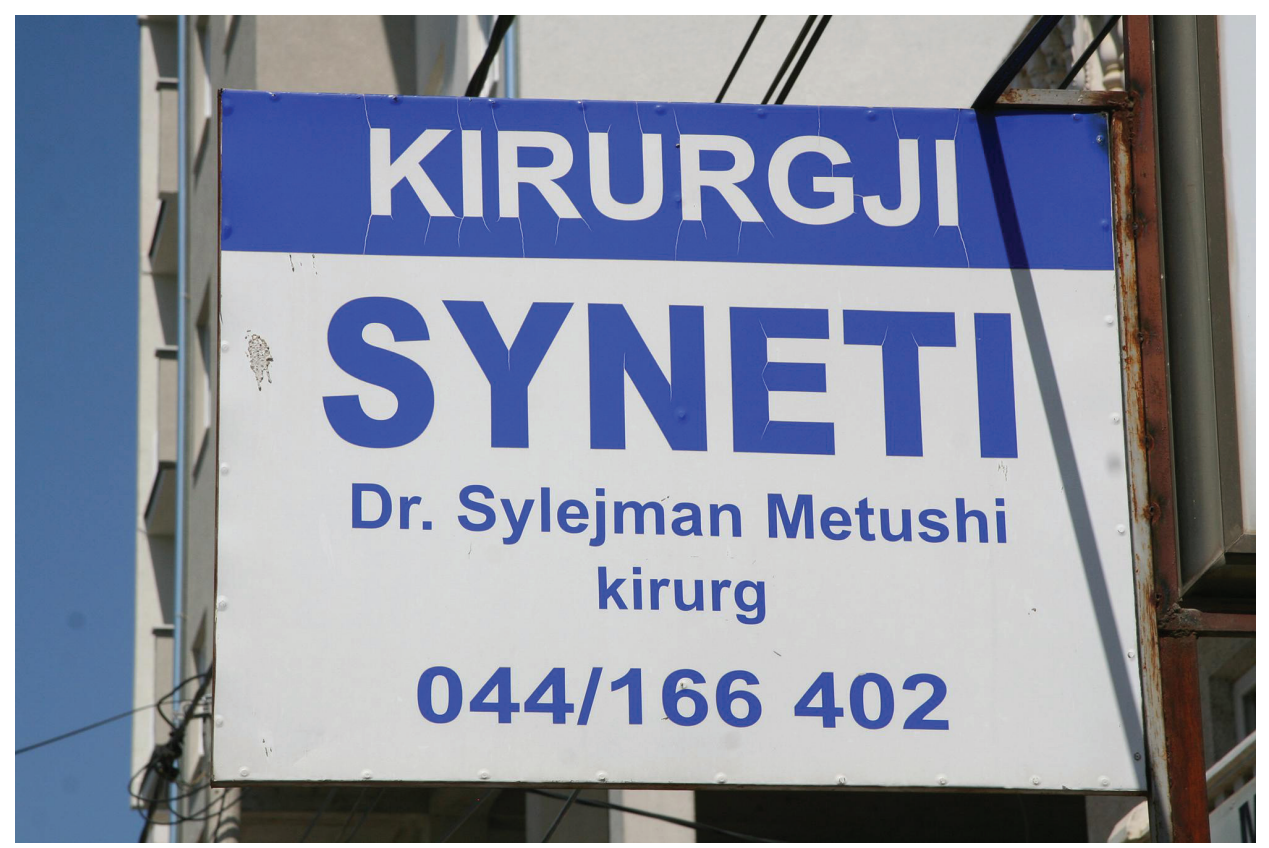

Figure 2. Signboard of a surgical clinic offering circumcision services. Ferizaj, Kosovo. Photograph by Alexander Novik, August 2011. 
In the Muslim community of the Balkans, an uncircumcised man is considered an exception from the rules: Tek ne pa synet janë vetëm të krishterë, ateistë dhe fukarenj - ata nuk kanë páre për kët gjë (Albanian, dialectal: 'Among us, the uncircumcised are only Christians, atheists and paupers - they do not have the money for it's).

In modern Albania, there are still the stories that after Skanderbeg's ${ }^{7}$ death the Turks, ultimately unable to convert the entire population of the country to Islam, ordered men, regardless of their faith, to be circumcised, as a sign of their loyalty to the sultan. ${ }^{8}$ Nevertheless, on most of the territories where the Albanians live, circumcision is viewed as a purely Muslim prerogative - a vast majority of the Orthodox and the Catholics do not perform this operation. The same can be said about the Slavic population of the Balkan Peninsula: circumcision is recorded among the Bosnians, the Gorani (a Muslim ethnic group inhabiting the Gora region - the triangle between Kosovo, Albania, and North Macedonia), the Torbeši (Macedonian Muslims), the Muslims of Montenegro (the Mrković/Mrkojević tribe), the Pomaks in the Rhodope Mountains (Bulgaria), the residents of Sandžak, etc., who practice Islam. The Southern Slavs, who practice Christianity in the form of Orthodoxy or Catholicism, or any other religion apart from Islam, regard circumcision as a marker of belonging to the Muslim community (Fig. 3).

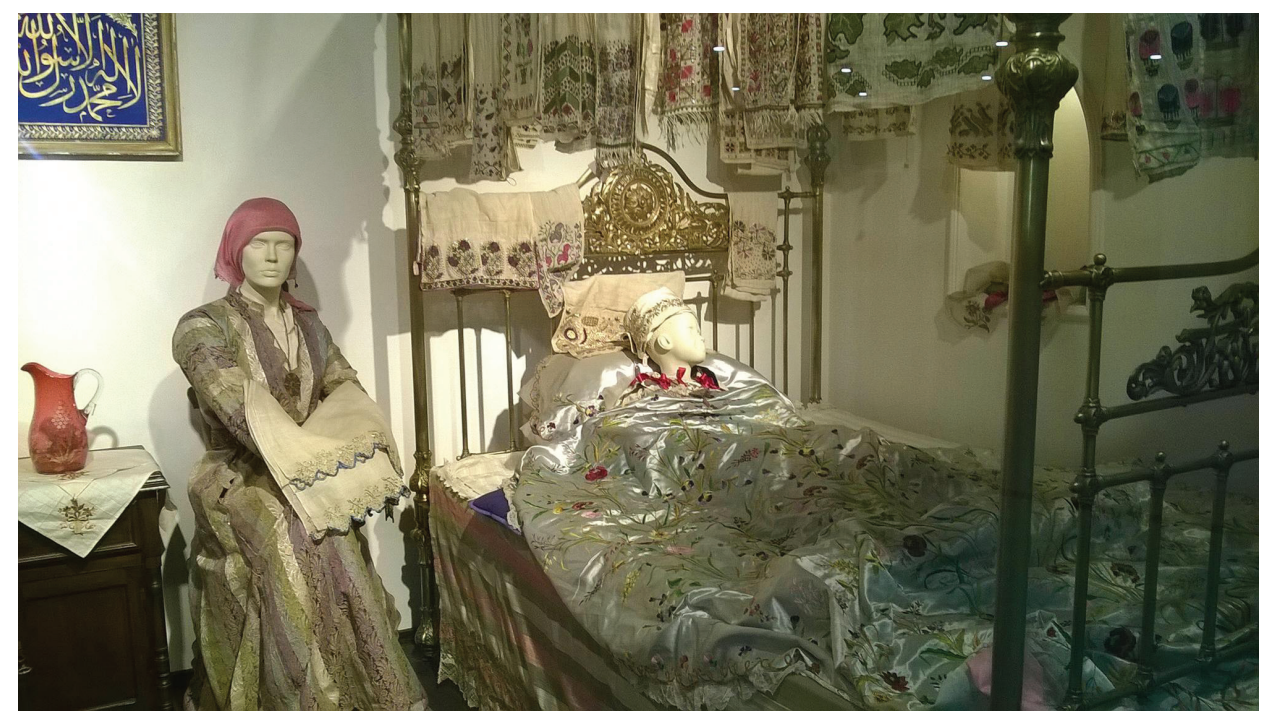

Figure 3. Ethnographic exposition "The Custom of Circumcision". Estergon Castle Turkish Cultural Center, Ankara, Turkey. Photograph by Alexander Novik, November 2019. 


\section{INNOVATIONS VS. "IT IS NOT OUR WAY"}

Though male circumcision is almost obligatory among the Balkan Muslims, female circumcision has almost never been recorded there. In various other regions of the world this type of religious practices are described fairly well (Nussbaum 2000 [1999]). Female circumcision ${ }^{9}$ is recorded in Africa and Oceania; it used to spread in the Caucasus ${ }^{10}$ and elsewhere. Among different hypotheses, the following explanation of the origin of this practice has been suggested. During male circumcision, according to primitive beliefs, the foreskin of the genitals was removed and the head was left open - therefore, the parts that (in the opinion of the authors of the hypothesis which I do not share) looked like female labia were removed and the man was free of "female atavisms" (Novik \& Rezvan 2019: 131). Meanwhile, during female circumcision a special instrument (usually a sharpened wooden spade) was used to dissect the clitoral glans, which was viewed as an underdeveloped male genital organ remaining on a woman's body. Whatever the case, many ethnic groups still retain the practice of what they call female circumcision (Shell-Dunkan \& Hernlund 2004).

In many regions, especially in Africa, female circumcision has always been a more complex operation - it involves the removal of both inner and outer labia. In ancient Egypt female circumcision was a very widespread practice, and it is still performed on the territory today. Thus, in Egypt, according to statistics, up to 85 percent of women are circumcised. Over the last years, both the Egyptian society and the world press have raised voices against the barbaric tradition, but so far these protests have had no effect on the number of girls subjected to the procedure (Female genital mutilation 2020).

On the Balkan Peninsula, most Muslim believers have not even heard of female circumcision (even though extremist views and practices connected with them have lately found many followers there). For this reason, interviews on this topic were conducted only in a very delicate manner during fieldwork with the town and village population (there were only questions such as: Do you know about female circumcision? When did you find out about the existence of such a practice? Where is this rite recorded? etc.). The analysis of field materials shows that only a small number of the informants (not more than 10 percent) know anything about this practice. Usually the recorded answers are: "What, can you circumcise a woman? What can you even cut from her?"; "Nothing of this sort has even existed in our place. We've never even heard of it, not just in the village, but even, say, in town" (AMAE: Novik 2013; AMAE: Novik 2015; FWMA 1987, 2009, 2014, 2015, 2016, 2019). People living in towns (Tirana, Durrës, Pristina, Prizren, Skopje, Ohrid, etc.) demonstrate a better knowledge of the topic of female circumcision than village residents. It can be explained 
by a higher level of urban residents' education, their wider knowledge of events in their country, region, and the world, and wider informational connections. Often the answers of urban residents include opinions such as: "We don't have such a tradition. Now the Arabs are building mosques around here. Maybe they have it. But it has not reached us yet"; "We learned of it when the refugees came, but it's an unheard-of thing for us". The following interview fragment is rather significant, in my opinion:

Lately, we have had an increase of Muslim influence. Saudi Arabia builds all our mosques. It also forces its values on us. Albanian women have never worn shawls, wrapped up completely. It was only in the sultans' time. Under Enver, women served in the army! With machine guns! What hijabs? Now it's coming back to us. But that's not because the Albanians became very strong believers. Just... because of the poverty. Many families are poor. They go to the mosque. And they say to them: here is money for you, but for that your women must wear hijabs and dress in the Muslim fashion. They pay them 200000 leks (in the old money), that's almost 200 euros a month. So women in that family begin walking around dressed in that Muslim fashion. But that's only how they look in the streets, and at home they walk around with bared bellybuttons! It's all for show!

And what's that female circumcision? There, before the Pope of Rome's visit, just a day before, they arrested 29 imams in Kosovo! They said they were preparing extremists there. They studied in Egypt, in short, in the Near East. Maybe they were preaching about female circumcision too. But our people won't accept much of this. That was in Kosovo. And it's more so in Albania! Here, the relatives won't allow to do what hasn't been done in the family! ${ }^{11}$

There have been attempts to introduce female genital mutilation in the west of the Balkans, mainly connected with the refugees that arrive in the region on their way to the wealthy countries of Western Europe. But these attempts have caused violent opposition and revulsion among the local population. In any case, the rite of circumcision among Balkan Muslims is firmly associated with the rite of male initiation and is viewed as an important stage in a man's life.

\section{INTERPRETATIONS OF THE RITE OF CIRCUMCISION}

In the folk Islam the tradition of circumcision can be interpreted differently. Some members of the Muslim culture explain this tradition with several reasons that contributed to the building of the widespread practice. According to 
the folk beliefs, a circumcised young man, compared to his uncircumcised agemates, has his sexual awakening at an earlier age, and it contributes to his maturing on the whole, the wish to enter an intimate relationship and have a wife and a family. That is to say, the circumcision practice aids the creation of Muslim families at a young age, the birth of more children - the loyal servants of Allah and the spiritual and secular powers and leaders, who were the ones that contributed in many ways to the scrupulous observance of this tradition (cf. Xhagolli 2008: 21-37).

At the same time, other folk explanations of the circumcision practice are recorded - they also are directly linked with sexuality and united in the idea of having as many children as possible.

A circumcised man has a larger penis. Well, if not larger, then thicker - the foreskin doesn't prevent it from getting thicker. The others, the Christians, are different. Our tradition's the right one. It's better for the family line to continue. ${ }^{12}$

When you're circumcised, you can perform longer during intercourse. Because the skin is less sensitive - it happens like that. A circumcised penis always touches something, the clothes, the underclothing. That's why it demands more time for the intimate act, the arousal and the sex. And the uncircumcised one - it's protected by the foreskin. That's worse for the intercourse. The uncircumcised have it quick. We Muslim men are better fit for intimate relations. That's why we have more children, too. ${ }^{13}$

Such explanations, as field data demonstrates, are recorded in the Muslim communities not only in the Balkans, but also in the Caucasus region, Central Asia, the Near East and Northern Africa.

There have been new interpretations not just of the religious and pragmatic elements of circumcision, but of the practices accompanying it, which are closely related to the ritual cycle of life, festive culture, everyday customs, moral stereotypes, family relationships, folk medicine etc. - the complex that comprises the cultural code of Balkan Muslims.

We have a large family. When my brothers and I were circumcised, it was a reason to gather everyone. It was an expensive feast for our family. That's why the parents delayed the rite, so that we would all have it on the same day and they won't have to celebrate the circumcision of each of the brothers. We have a tradition of inviting all the friends and relatives. The family prepares the food, and the guests bring presents. Now they only give money. The closer the relative, the more money he has to give. If it's an uncle, they expect a large sum. And if it's some distant relation, he can give little. The rite is when you can see how others view you. 
What does the present-giving look like? My brothers and I were lying in a room. Grown-ups came in one by one. Only the men come in. Women don't participate in it. They came to us one by one and saw if we were circumcised. Afterwards they left us money. It's a special rite-making sure that the circumcision was performed. And then they continued to celebrate - everybody, both men and women.

In the end, we didn't receive that much money. I got maybe 40 euros. And the celebration costs a lot. ${ }^{14}$

This narration excellently shows the traditional nature of the celebration and the family solidarity - the rite is a consolidating factor. As a rule, even when it comes to obviously innovational phenomena and facts, Muslim believers tend to note the elements of legacy that unite them with the ancestors' customs.

For example, among the Muslims of Albania and Kosovo, chamomile infusion is used to treat the wound after the surgery (Novik 2017: 116-131). As noted earlier, the rite used to be performed by an imam or mullah from the village or the city, and some barbers also specialized in performing the operation. In the past few decades, practically the entire Muslim population of Albania, Kosovo, North Macedonia, and Montenegro has asked doctors in private or public hospitals to perform the traditional rite. The circumcision is performed by a surgeon who uses both modern surgical equipment and the newest anesthetics. After the operation, there is a period of recovery, when one needs to watch over the wound, to avoid infection, etc. As a rule, this process is controlled by the new Muslims' mothers. The doctors themselves advise them to use chamomile infusion. ${ }^{15}$ In the society's eyes, this fact legalizes inviting a qualified doctor rather than an imam, since the following actions with using herbs for treatment support the tradition several centuries long.

My brothers and I were circumcised on the same day; it happened because for economy's sake the parents figured out how to organize it simultaneously for all the brothers. The doctor did the circumcision very quickly; he had that instrument, a scalpel or something like a scalpel. And then he smeared it with some green stuff. So that the wound won't hurt. But it didn't hurt anyway ...

And then we lay in bed at home, each of us in their own bed. First they put a shoe box to the ... so that the wound didn't touch the blanket ... And Mom came to us and moistened the wound with chamomile tea. How did she do it? She just took a bag of chamomile tea, a simple one from the shop, brewed it, let it get a bit cooler. Then she took some wool, dipped it in the tea and moistened the wound... She did it for a week, 
once a day. And then she stopped. It didn't hurt, and there was nothing. That's traditional for us. ${ }^{16}$

As we can see from the interview fragment above, nowadays even simple packaged chamomile tea, sold in corner shops, is used as a medicine - many women do not even go to a pharmacy to buy a medical infusion, which is more suitable for the purpose. In the rite of circumcision, this normal medical practice has entered the sacred sphere, ideologically "shielding" the inevitable innovations in the modern technological society that enter the religious and ritual life.

The Muslims in the west of the Balkans demonstrate a more conservative mindset in their religious practices, everyday customs, and family relationships than members of other religious groups (both anthropological studies and sociological surveys show it). The sphere of tradition is usually associated with the sacred among them, so we can freely state that many features and elements are part of a continued tradition several centuries long.

\section{CONCLUSIONS}

Circumcision is one of the most widespread ritual practices among the Muslim peoples of the Balkan Peninsula. Historically, male circumcision spread in the region after the Ottoman invasion in the fourteenth-sixteenth centuries. The Islamization of part of the Southern Slavs, Albanians, and Eastern Romance people led to the practice of circumcision taking root and gradually becoming perceived not just as a tribute to the religious identity but as a cultural norm. The tradition that never gets explicitly brought up in the sacred text of the Quran has become practically mandatory for the Balkan Muslims as well as for most Muslim communities over the world.

During different periods, normative acts of secular and religious authorities, everyday culture of the referent groups, consisting mostly of new converts, have considerably influenced the ritual practices. The practice of circumcision that originates from the East also affected non-Muslims during a particular period in several regions of the West Balkans (such as southeast Albania and Kosovo). However, most people strongly associated circumcision with belonging to the Muslim community; moreover, considered it practically the main act of conversion to the faith. In any case, I have recorded extensive evidence of the fact that most of my informants view circumcision as a more important act than the rite of initiation of a child/adult into the Muslim faith (which is performed by an imam, mullah or khoja, and is obligatory). 
Among the rites of passage (Gennep 2004 [1909]; Sedakova 2007), circumcision is considered by Muslims one of the main ones, as it symbolizes the transition from the status of a child to the status of an adult who has all the rights of a "full-fledged" man - even though circumcision can be performed at an early age. This role of the rite is evidenced in the terminology. For example, in colloquial Albanian circumcision is called dásma e vógël 'little wedding', which shows the important status of the event not just from the religious aspect, but socially as well, for the wide circle of relatives and often the entire local community. Only a circumcised man is considered an adult, all the exceptions are viewed as marginal.

In the second half of the twentieth century, the technical side of the rite was radically changed, but it has not affected its sacred and traditional elements. Instead of the customary practice of circumcision, performed by imams and barbers before the $1950 \mathrm{~s}$, in the past 70 years it has been recorded, with increasing frequency, that the operation is performed by professional surgeons. This way, the prayers, earlier obligatory, are not read, the accompanying speech formulas are not pronounced, etc. However, despite the intrusion of modern medicine into the sacred sphere, there has been no refusal of traditional folk remedies - first of all, because of the popularity of medical herbs due to the global admiration of ecologically safe food. For that reason, after the operation is performed at a hospital, mothers usually continue to treat their sons at home, using traditional medicines - infusions of chamomile, celandine, etc.

\section{NOTES}

1 The Orthodox celebrate the feast on the 14th of January. The Circumcision of Christ, according to the teaching of the Church, is included in the calendar as the celebration of when "on the eighth day after His Nativity Jesus Christ received circumcision. On that day, He was given the name of Jesus" (Prazdnik 2006).

2 During the past fifty years, this operation has been covered by medical insurance in the USA (along with appendix and gland removal), and many parents wish to receive additional medical treatment without financial expenses. Currently, more than 50 percent of men in the USA are circumcised. The popularity of circumcision is also influenced by the information, based on survey results and given by many medical centers, that circumcised men are less at risk of contracting AIDS and other diseases (Krieger 2012: 3-13).

3 This is why critics of Islam point out the overly "physiological" nature of Muslim holy texts. 
4 Fis (Albanian: $f i s,-i$ ) - a tribal group among Albanians, "considering themselves relatives by the male line. They come from one ancestor, observe exogamy" (Ivanova 1973: 65; Novik 2016: 610-612).

5 Krahína (Albanian: krahin/ë, -a) - historical and ethnographic region in the Albanian lands (Zojzi 1962: 16-64).

6 Recorded in August 2015 from an Albanian Muslim Sunni, 26 years old, born in Pristina, Kosovo, lives in Switzerland (AMAE: Novik 2015: 16-18).

7 Gjergj Kastrioti (1405-1468), known as Skanderbeg (Albanian: Skënderbej or Skënderbeu), was an Albanian nobleman, politician and military commander, who led a rebellion against the invasion of the Ottoman Empire.

8 These folklore stories and legends are reflected in modern fiction (for example, in the works of Ben Blushi (b. 1969)) (Blushi 2008). However, historical facts confirming this information have not been recorded.

9 In different Balkan languages no separate term for female circumcision has been adopted. In the Western countries, there has been a fight against this practice since the 1980s. Thus, in international medical and human rights communities (such as the World Health Organization and the UN) the term 'female circumcision' is tabooed. Instead, terms such as 'female genital mutilation' (FGM) and 'female genital cutting' (FGC) are used. Moreover, the UN has established the International Day of Zero Tolerance for Female Genital Mutilation, celebrated on the 6th of February (Zero Tolerance n.d.; see also Female genital mutilation 2020).

${ }^{10}$ Over the past few years, due to the influence of radical religious propaganda, a spread of female circumcision practice has been detected in Dagestan. Many secular communities and human rights organizations try to fight it, along with many priests who are firm opponents of the "medieval" custom (Karpov 2001).

${ }^{11}$ Recorded in September 2014 from an Albanian Muslim Bektashi, 51 years old, born in Këlcyra, Albania, lives in Durrës (FWMA 2014).

12 Recorded in Ukraine in August 1987 from a Tajik Muslim Sunni, 26 years old, born in Leninabad/Khujand, Tajikistan, lives in Tajikistan (FWMA 1987).

${ }^{13}$ Recorded in August 2010 from an Albanian Muslim Sunni, 18 years old, born in Peja/ Peć, Kosovo, lives in Pristina, Kosovo (AMAE: Novik 2010).

${ }^{14}$ Recorded in August 2013 from an Albanian Muslim Sunni, 21 years old, born in Peja/ Peć, Kosovo, lives in Pristina, Kosovo (AMAE: Novik 2013).

${ }^{15}$ Chamomile infusion (Chamomillae Flos L., Matricaria chamomilla L., Compositae family; Albanian variations of the name: kamomíl, $-i$, maráq, $-i$ ) is traditionally used by the Albanians to treat an entire number of diseases - eye diseases, swelling, wound disinfection (Novik 2017: 116-131). The medical uses of chamomile have been recorded among the Albanians both in the first surviving descriptions of folk medicine and in modern times (Sulaj 2013: 131-133).

${ }^{16}$ Recorded in August 2013 in Pristina from an Albanian Muslim Sunni, 21 years old, born in Peja/Peć, Kosovo, lives in Pristina, Kosovo (AMAE: Novik 2013). 


\section{REFERENCES}

Blushi, Ben 2008. Të jetosh në ishull. [To Live on an Island.] Tirana: Shtëpia Botuese "TOENA".

Çoçaj, Nexhat 2012. Hasi - enciklopedi etnokulturore. [Has - Ethnocultural Encyclopedia.] Vol. IV: Ritet e lindjes, dasmës dhe vdekjes. [Rites of Birth, Wedding and Funeral.] Durrës: Pavarësia.

Denny, Frederick Mathewson n.d. Circumcision. In: Jane Dammen McAuliffe (ed.) Encyclopaedia of the Qur'ān. Online edition. http://dx.doi.org/10.1163/18753922_q3_EQSIM_00079.

Elbasani, Arolda \& Roy, Olivier (eds.) 2015. The Revival of Islam in the Balkans: From Identity to Religiosity. London: Palgrave Macmillan.

Gennep, Arnold van 2004 [1909]. Rites of Passage. London \& New York: Routledge.

Ivanova, Iuliia 1973. Severnaia Albaniia v XIX-nachale XX v. Obshchestvennaia zhizn'. [Northern Albania in the 19th - Early 20th Centuries. Public Life.] Moscow: Nauka.

Karpov, Iurii 1996. Dzhigit i volk: Muzhskie soiuzy v sotsiokul'turnoi traditsii gortsev Kavkaza. [Dzhigit and the Wolf: Men's Unions in the Sociocultural Tradition of the Highlanders of the Caucasus.] St. Petersburg: MAE RAN.

Karpov, Iurii 2001. Zhenskoe prostranstvo v kul'ture narodov Kavkaza. [Female Space in the Culture of the Peoples of the Caucasus.] St. Petersburg: Peterburgskoe vostokovedenie. Available at https://rusneb.ru/catalog/000199_000009_000717505/, last accessed on 15 October 2020.

Krieger, John N. 2012. Male Circumcision and HIV Infection Risk. World Journal of Urology, Vol. 30, No. 1, pp. 3-13. https://doi.org/10.1007/s00345-011-0696-x.

Novik, Aleksandr 2016. Svad'ba i traditsii braka u albantsev Ukrainy. [Wedding and Marriage Traditions of the Albanians of Ukraine.] In: A. Novik \& Y. Buchatskaia \& D. Ermolin \& A. Dugushina \& M. Morozova (comps.) "Priazovskii otriad": Iazyk i kul'tura albantsev Ukrainy. Part I, Vol. 1. St. Petersburg: MAE RAN, pp. 586-726. Available at http://ib.kunstkamera.ru/files/lib/978-5-88431-313-2/978-5-88431313-2_11.pdf, last accessed on 15 October 2020.

Novik, Aleksandr 2017. "Gornyi chai", shalfei, chai, romashka i kofe v traditsii, narodnoi meditsine i etikete albantsev i grekov Khimary i Dropula. ["Mountain Tea", Sage, Tea, Chamomile and Coffee in the Tradition, Traditional Medicine and Etiquette of the Albanians and Greeks of Himara and Dropul.] Acta Linguistica Petropolitana. Trudy Instituta lingvisticheskikh issledovanii, Vol. XIII, Part 2: Etnobotanika 2: Rasteniia v iazyke i kul'ture, pp. 116-131. Available at https:// alp.iling.spb.ru/static/alp_XIII_2.pdf, last accessed on 15 October 2020.

Novik, Aleksandr \& Rezvan, Efim 2019. Islam na Balkanakh. Chast'I. Obriady perekhoda i semeinaia obriadnost': rozhdenie, obrezanie: uchebnoe posobie. [Islam in the Balkans. Part I. Rites of Passage and Family Rituals: Birth, Circumcision: A Training Manual.] St. Petersburg: Izdatel'stvo SPbGU.

Nussbaum, Martha C. 2000 [1999]. Sex and Social Justice. New York \& Oxford: Oxford University Press. 
Oren (Nadel'), Itskhak \& Prat, Naftali (eds.) 1992. Obrezanie. [Circumcision.] In: Itskhak Oren (Nadel') \& Naftali Prat (eds.) Kratkaia evreiskaia entsiklopediia. Vol. 6. Jerusalem: The Hebrew University of Jerusalem, pp. 39-42. Available at https://eleven.co.il/judaism/commandments-and-precepts/13031/, last accessed on 15 October 2020.

Sedakova, Irina 2007. Balkanskie motivy v iazyke i kul'ture bolgar: Rodinnyi tekst. [Balkan Motifs in Bulgarian Language and Culture: Birthlore.] Moscow: Indrik. Available at https://inslav.ru/publication/sedakova-i-balkanskie-motivy-v-yazykei-kulture-bolgar-rodinnyy-tekst-m-2007, last accessed on 15 October 2020.

Shell-Dunkan, Bettina \& Hernlund, Ylva 2004. Female Genital Cutting: Social and Cultural Dimensions of the Practice and the Debates. In: Carol R. Ember \& Melvin Ember (eds.) Encyclopedia of Medical Anthropology. Vol. 1: Topics. New York: Springer, pp. 252-262. https://doi.org/10.1007/0-387-29905-X_30.

Sulaj, Elsa (ed.) 2013. Bimët Mjekësore - Instituti i shkencave - 1980. [Medicinal Plants Institute of Sciences - 1980.] Tirana: Shtëpia botuese: Akademia e Shkencave dhe e Arteve e Kosovës.

Wensinck, Arent Jan 1986. Khitān. In: Encyclopaedia of Islam. Vol. 5. Leiden: E. J. Brill, pp. 20-22. Available at https://referenceworks.brillonline.com/browse/ encyclopaedia-of-islam-2/alphaRange/Kh\%20-\%20Kn/K?s.start=240, last accessed on 15 October 2020.

Xhagolli, Agron 2008. Synetia ndër shqiptarë. [Circumcision among Albanians.] Kultura popullore, Vol. 1-2, pp. 21-37.

Zojzi, Rrok 1962. Ndamja krahinore e popullit shqiptar. [Regional Division of the Albanian People.] Etnografia Shqiptare, Vol. 1, pp. 16-64.

\section{ARCHIVAL SOURCES}

AMAE - Archive of Peter the Great Museum of Anthropology and Ethnography (Kunstkamera) of the Russian Academy of Sciences, St. Petersburg, Russia:

AMAE: Novik 2010 = Novik, Aleksandr 2010. Kosovo: Traditsionnaia kul'tura albantsev Kosovo. 15.08-28.08.2010. Polevaia tetrad'. Avtograf. [Kosovo: The Traditional Culture of the Albanians of Kosovo. 15.08.-28.08.2010. Field notebook. Autograph.] Collection K-1, aids 2, No. 1987, 23 pp.

AMAE: Novik 2013 = Novik, Aleksandr 2013. Kosovo: Traditsionnaia kul'tura albantsev Kosovo, iuvelirnoe delo, albantsy i slaviane. Polevye zapisi. Avtograf. 19.08.30.08.2013. [Kosovo. The Traditional Culture of the Albanians of Kosovo, Jewelry, Albanians, and Slavs. Field notes. Autograph. 19.08-30.08.2013.] Collection K-1, aids 2 , No. 2179, 36 pp.

AMAE: Novik 2015 = Novik, Aleksandr 2015. Kosovo. Traditsionnaia kul'tura albantsev Kosovo, iuvelirnoe delo, albantsy i slaviane. Polevye zapisi. Avtograf. 16.0830.08.2015. [Kosovo: The Traditional Culture of the Albanians of Kosovo, Jewelry, Albanians and Slavs. Field notes. Autograph. 16.08-30.08.2015.] Collection K-1, aids 2 , w/no., $32 \mathrm{pp}$. 


\title{
INTERVIEW MATERIALS
}

FWMA 1987 - Fieldwork materials of the author. Ukraine, 1987.

FWMA 2009 - Fieldwork materials of the author. Albania, Kosovo, 2009.

FWMA 2014 - Fieldwork materials of the author. Albania, Kosovo, Montenegro, 2014.

FWMA 2015 - Fieldwork materials of the author. Albania, Kosovo, Montenegro, 2015.

FWMA 2016 - Fieldwork materials of the author. Albania, Kosovo, Montenegro, 2016.

FWMA 2019 - Fieldwork materials of the author. North Macedonia, Albania, Kosovo, 2019 .

\section{INTERNET SOURCES}

Circumcision n.d. MedlinePlus.gov. U. S. National Library of Medicine. Available at https://medlineplus.gov/ency/article/002998.htm, last accessed on 14 October 2020 .

Zero Tolerance n.d. = International Day of Zero Tolerance for Female Genital Mutilation, 6 February. Un.org. Available at https://www.un.org/en/observances/femalegenital-mutilation-day, last accessed on 15 October 2020.

Female genital mutilation 2020. Who.int, 3 February. Available at https://www.who. int/news-room/fact-sheets/detail/female-genital-mutilation, last accessed on 15 October 2020.

Prazdnik $2006=$ Prazdnik obrezaniia gospodnia [Feast of the Circumcision of the Lord.] 2006. Pravoslavie.ru, 14 January. Available at http://www.pravoslavie.ru/2040. html, last accessed on 15 October 2020.

The Noble Qur'an n.d. Available at https://quran.com, last accessed on 14 October 2020.

\begin{abstract}
Alexander Novik is PhD, Head of the Department of European Studies, Peter the Great Museum of Anthropology and Ethnography (Kunstkamera) of the Russian Academy of Sciences, and Associate Professor in Albanian Philology and Balkan Ethnology at the Department of General Linguistics, Saint Petersburg State University, Saint Petersburg, Russia. His research interests are in the field of traditional and modern culture, ethnolinguistics, ethnic and religious minorities, folk costume, and festivity.

njual@mail.ru
\end{abstract}




\title{
A LOCAL MIDWIFE OR A DOCTOR? TWO SYSTEMS OF KNOWLEDGE IN BIRTHING PRACTICES OF RUSSIAN OLD BELIEVERS
}

\author{
Natalia Dushakova \\ Research Fellow, PhD \\ Russian Presidential Academy of National Economy \\ and Public Administration, Russia \\ nataliadusacova@gmail.com
}

\begin{abstract}
The article explores complex relationships between traditional midwifery and medical institutions as two legitimate knowledge systems in the communities of Russian Old Believers in the Republic of Moldova and in Romania. It is aimed at discussing beliefs and practices around giving birth with the help of a local midwife from the same community, their transformation caused by the access to maternity hospitals as well as distribution of roles between a traditional birth attendant and a doctor. The article is based on oral narratives of Old Believers who used to be local midwives or gave birth to children with the help of such a specialist. The narratives were recorded by the author in 2008-2018.
\end{abstract}

Keywords: anthropology of birth, birthing practices, medical doctor, Old Believers, traditional birth attendant, traditional midwifery

\section{INTRODUCTION}

The first maternity hospitals in the rural areas of Moldova and Romania appeared in the early 1960s. From this time on, professional obstetric care started displacing the institution of traditional midwifery. Nevertheless, even despite the official struggle with rural midwives, they have enjoyed great authority for a long time: women often preferred to give birth with the help of a traditional birth attendant, rather than call a doctor or go to any medical institutions.

Since the 1970s, anthropologists have been studying the process of pregnancy and childbirth in the conditions of modern health care, comparing it with traditional birthing practices. In the works of American scholars, childbirth in official medical institutions is considered as a modified rite of passage. These topics became a part of a separate area of studies known as anthropology of birth. Ann Oakley gave consideration to the process of pregnancy and delivery in the 
context of medicalization of everyday life, when control over pregnancy and the birth of a child passed from the mother to doctors. Based on rich materials, she analyzed the issue of choosing between childbirth in hospitals and at home (Oakley 1984). Since the 1990s, Russian researchers also studied the practice of obstetric care in an urban environment (see, e.g., Belousova 2003) and the subculture of women giving birth (Shchepanskaia 1994). Yvonne Lefèber and Henk Voorhoever studied practices of traditional birth attendants in Africa, Asia, and Latin America, and revealed common practices and beliefs despite all the cultural differences. Scholars argue that it can be useful for obstetrics in other countries to learn from these specialists about their techniques in natural childbirth (Lefèber \& Voorhoever 1997).

Jeanmarie Rouhier-Willoughby pays attention to the two views of birth, which are "variously called the 'midwifery' model and the 'medical' model (Lichtman; Rothman) or the 'holistic' model and the 'technocratic' model (DavisFloyd)" (Rouhier-Willoughby 2003: 227). According to Brigitte Jordan, if there are several types of authoritative knowledge, which is the case with childbirth practices, one kind of knowledge often takes over. So when maternity hospitals spread, two institutions - traditional midwifery and modern obstetrics - exist as "equally legitimate parallel knowledge systems" and "people move easily between them, using them sequentially or in parallel fashion for particular purposes" (Jordan 1997: 56). "But frequently", she adds, "one kind of knowledge gains ascendance and legitimacy" (ibid.).

This article explores the way the two knowledge systems have been interacting in the communities of Russian Old Believers in the Republic of Moldova and in Romania since the middle of the twentieth century. Based on oral narratives of former local midwives and women who used the help of a traditional birth attendant from the same community, this article discusses beliefs and practices around giving birth before and after medical institutions were opened, as well as the distribution of roles between a local midwife and a doctor.

\section{THE FIELD AND SOURCES}

Fleeing from the persecution by the tsarist government and the official Orthodox Church, those who refused to follow church reforms (from 1782 called Old Believers) migrated to the confines of the Russian Empire. Establishing closed communities where they could reproduce pre-schism Orthodoxy, they still could not be fully separated from the world around them. Building their claim of true Orthodoxy on the refusal to change (Naumescu 2016: 3), Old Believers maintained their faith together with essential traditional practices. 
In the north-west Black Sea region Old Believers have settled since the early eighteenth century. One of the first Old Believer villages on this territory was Kunichnoe (Cunicea), situated in modern-day Moldova. Apart from that, up to the present Old Believers reside in other settlements in the Republic of Moldova (the villages of Pocrovca, Egorovca, Dobrudja Veche [Staraia Dobrudzha], the cities of Chisinau, Cahul, also Tiraspol and Bender in Transnistria, and others); Southern Ukraine (the villages of Staraia Nekrasovka, Novaia Nekrasovka, Muravlevka, Mirnoe, Zhebriiany (Primorskoe), the cities of Vilkovo, Izmail, Kiliia, and others); Romanian Dobrudja (the villages of Sarichioi, Jurilovca, Slava Rusa, Slava Cercheza, and others). (For general overviews of origin, history, and different aspects of Old Believers' culture in the region see, e.g., Crasovschi 2005; Ipatiov 2001; Litvina 2018; Prygarine 2004; Tudose 2015.)

I have conducted research in 17 settlements of the region since 2008 (see the map below, Fig. 1). For most of these localities the neighboring population includes, first of all, Moldovans, Ukrainians (in the Republic of Moldova and southern Ukraine) and Romanians (in Romanian Dobrudja). As for religious identities of the population living next to Old Believers, they are mostly Orthodox Christians of the main current called Nikonians, because they accepted the reforms introduced by Patriarch Nikon in the mid-seventeenth century. There are also a small number of Catholics, Protestants, and Jews. However, Old Believers themselves are not homogeneous either. In the north-west Black Sea region most Old Believers belong to the Belokrinitskaya Hierarchy, a smaller number of Old Believers are of Novozybkov Hierarchy: they are all popovtsy, which means priestly (with priests). In some localities there are Old Believers of both denominations (in the cities of Bender, Tiraspol). There are just a few localities with bezpopoutsy (priestless Old Believers), for instance, they reside in the city of Edinets in Moldova, but this paper is based on the data collected among the popoutsy.

Despite all the differences in local variants of cultural practices and beliefs, field studies among the Old Believers of the north-west Black Sea region demonstrate that local residents share general knowledge of ritual practices associated with preparing a future mother for the childbirth, the process of delivery, postpartum period, and care for the new mother and the baby (for more details on vernacular beliefs, prohibitions, and prescriptions concerning giving birth in Old Believer communities of Moldova and Romania see Dushakova 2018).

There are not many papers on birth rites of the Old Believers of the northwest Black Sea region. They are mostly either brief descriptions of birthing practices within general studies on Old Believer culture (Ipatiov 2001; Tudose 2015) or descriptions of field materials framed as common knowledge characteristic of a homogeneous tradition and with no metadata provided (Zakharch- 
enko 2004; Zakharchenko \& Petrova 2005; Stoianova \& Trotsyk 2006; Trotsyk 2005). More details on birthing practices of the Old Believers in Romania can be found in Aksiniia Krasovski's paper (Krasovski 2001) and Elena Arslanova's monograph (Arslanova 2010) devoted to life cycle rituals of the Old Believers in the Astrakhan' region, who migrated from Romanian Old Believer villages in 1947 and shared memories of their lives before settling in the USSR. In her studies of archaic peculiarities in the language and folk culture of Russian Old Believers in Romania, Anna Plotnikova pays attention to terminology and old ritual practices associated with birth and traditional midwifery (Plotnikova 2016: 40-50). She also describes a yearly celebration in honor of midwives in Russian villages in the Balkans as a tradition brought from the historical motherland (Plotnikova 2007). On the basis of materials collected among Nekrasov Cossacks - Old Believers who re-emigrated from Turkey to the Stavropol region of Russia - this holiday is described by Tatiana Vlaskina (2009). Peculiarities of birth rites and beliefs concerning midwifery among the Old Believers in Bulgaria have been studied by Elena Uzeneva (2008).

This paper is mostly based on the interviews with Russian Old Believers from the Republic of Moldova and Romania, using also the data from other settlements with Old Believer population for a broader picture and comparison. All the interviews were conducted in Russian, the native language of my interlocutors. On the basis of these materials an online database of folklore and ethnographic data was elaborated. Today the digital archive "Birth-Christening Rites of Old Believers of the North-west Black Sea Region" can be accessed online. ${ }^{1}$ The internet version of the database includes fragments of interviews in textual format accompanied by all the necessary metadata.

Although "the Soviet campaign against rural midwives began in the twenties and thirties and continued until the death of Stalin in 1953" and "after that for some time the persecution of midwives stopped" (Olson \& Adonieva 2016: 233; Ransel 2000), in the explored region of the former Moldovan SSR it was officially forbidden to call a local midwife for much longer, until the end of the 1970s. According to the memories of my interlocutors, in Romanian Old Believer villages the situation was similar: by the late $1970 \mathrm{~s}$, deliveries outside hospitals were already less common.

Currently, traditional obstetric care practices that have given way to qualified medical care are mainly preserved in the memory of the older generation. Therefore I mostly spoke with older women who themselves had acted as midwives or used their help at any stages of pregnancy, childbirth or postpartum care. The names of my interlocutors are encoded in the article, but I provide information on the locality and years of birth. 


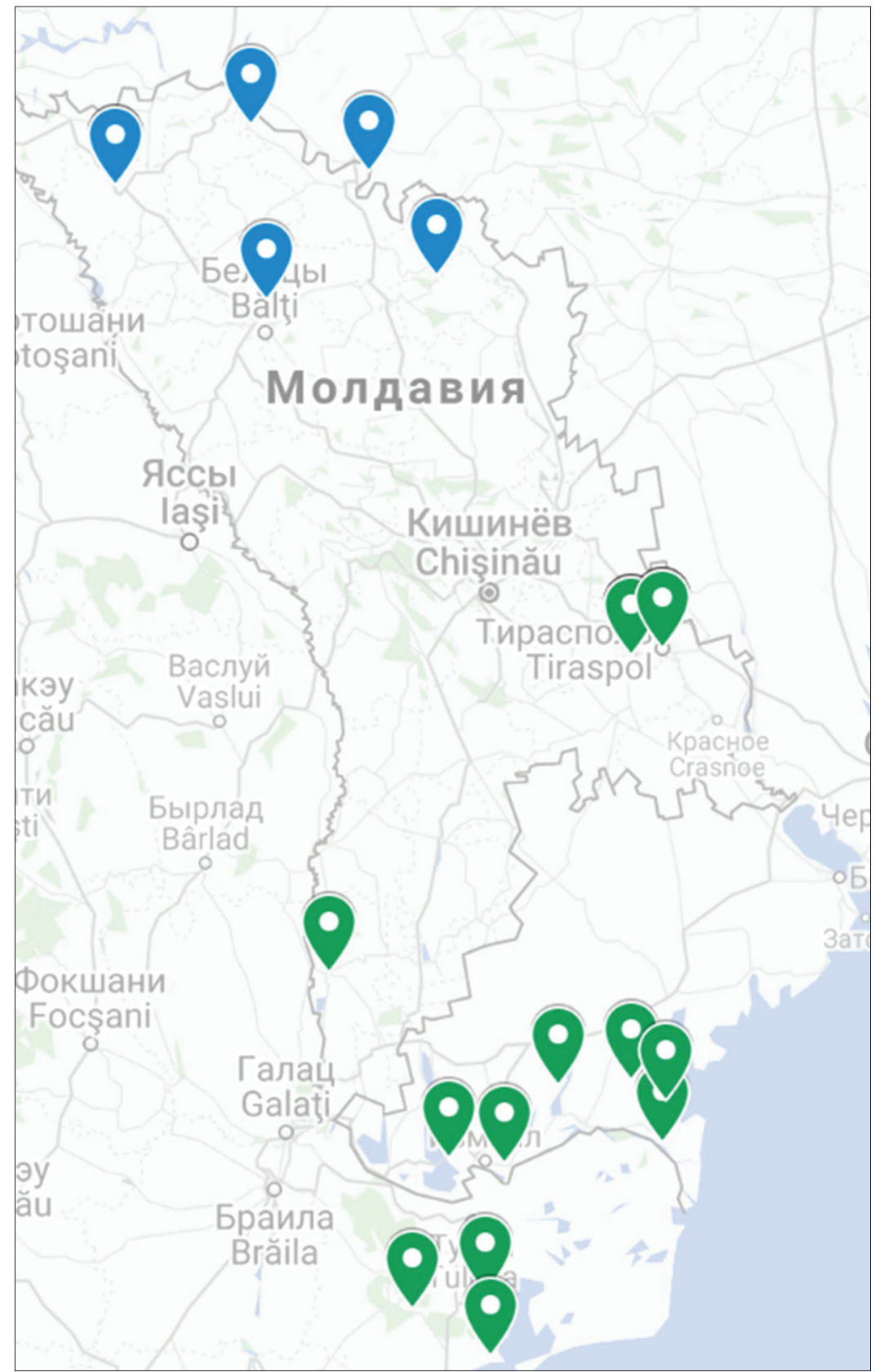

Figure 1. A map of research sites with Old Believer population in the north-west Black Sea region (Republic of Moldova, Romanian Dobrudja, and southern Ukraine), created by Natalia Dushakova based on Google Maps, 2020. 


\section{BEFORE MEDICAL INSTITUTIONS WERE OPENED: TWO PIECES OF EVIDENCE}

On research sites women remember giving birth in a bathhouse or in a separate room with the help of a local midwife. In the Republic of Moldova and in Romania, Old Believers called her babka, babushka, less often povitukha or povivukha. During the season of field work women often gave birth in the field. In such cases, they also turned to midwives:

Now in the hospital, and then babka tied the umbilical cord, yes, babka did everything. Then there was a babka, there were no doctors. There were doctors, they were somewhere, and our village - first of all, we didn't have a hospital, and second, there was nothing to get on, then there was no transport, and if you put a pregnant woman on a cart... She's working in the steppes, and she... suddenly felt unwell. One babka who knew in a moment took water there, and she brought [a child]. The baby was wrapped in her shawl. Then the child was wrapped in her clothes. This is how it used to be. ${ }^{2}$

As a rule, when the child was about to be born, the husband of the woman in labor or a neighbor called the midwife:

I gave birth to my first one in 1948. The first son was born. Well, I had time ... My husband went, brought a babka - a povitukha. Here. He brought a babka, this babka delivered my baby. Here. And the second girl was [delivered] by a babka, too, but the point was that it was too late.... Oh ... I came, but my husband was drunk, asleep. I knocked, knocked, knocked - I couldn't get through, I hardly reached out, it took him a while to open the door... And then I already had contractions. I asked him: "Call a babka!" And he was like... [laughing]: "What babka do you need? Nothing will happen to you!" He didn't want to go. And then he went. While that babka was coming, I - there was no wooden floor, there was dirt floor - I was on that... there was nothing to put on the floor, whatever. I was on the floor, on the dirt floor, on the damp one. Until that babka came, I froze completely. ${ }^{3}$

Sometimes a midwife delivered babies herself, but more often she was assisted by older female relatives or a neighbor of the woman in labor. The presence of children and men was strictly prohibited. 


\section{RURAL MIDWIFE: KNOWLEDGE AND FUNCTIONS}

According to my interlocutors, in the 1940s-1970s several local birth attendees acted at the same time at the research sites. Local residents often emphasized that not every woman could take this role: a widow or an older knowledgeable woman ("clean", in menopause status, see below) was preferable:

[The midwife herself taught a young one, didn't she?] Yes, yes. She was telling what and how to do all the things. [And who could be ... well, not everyone could be a midwife, right?] Well, of course, not anyone. She knew who could. Widows were often taken. [Were widows taken?] Yes, she had to be a widow. ${ }^{4}$

That could be wherever: in the yard, in the garden, and in the house - they could bring children anywhere. And in the bathhouse and around. And there was a special midwife like moaşa ["midwife" in Romanian - N.D.], such a midwife was called. She ... not every person could do these things, but old people did it, they served like doctors. ${ }^{5}$

Earlier, they taught these things, showed them, they knew how to raise the belly, they knew everything... There she put her hand and felt that it hurt here; she did it like a doctor. Or when someone broke an arm, or dislocated, or something, she would come and touch and say: "Hey, it's out of its place, and you should do it this way or that way." They bandaged that, did that, they were all like doctors, they understood everything; they had this talent from God. And they taught a lot. There was, let's say, there were many times when a babka had a younger daughter at home, and she taught her. There were many times that the mother died, and her daughter continued. A lot of this happened. But not any longer. ${ }^{6}$

As the interviews show, the knowledge was transferred either from mother to daughter, or from a knowledgeable woman ( $b a b k a$ ) to a younger woman suitable for this role. Apart from that, she had no professional training. The rules for choosing a midwife were based on special requirements for the purity of a woman, which in many Slavic traditions included a prohibition concerning the contact with death / the dead: midwives were strictly forbidden to wash the dead, "since the same gestures regarding a newborn would be fatal for them: death is contagious" (Kabakova 2001: 112-113). Contact with death among the Slavic people is considered as "a special case of ritual impurity" (Kabakova 2009a: 82). According to Elena Arslanova, Old Believers in Romania preferred a widow as a midwife; also her purity implied the absence of contact with the 
dead (Arslanova 2010: 35). However, in the village of Cunicea (Republic of Moldova), a midwife also washed the dead, and there were no beliefs recorded that this could have been prohibited. Currently, this woman no longer acts as a midwife, but continues to wash the dead, along with other washers.

Midwives knew ways of determining the gender of unborn babies. Besides a widely-spread practice to find out the baby's gender by the shape of the mother's abdomen, they also took into consideration the fetuses' behavior: "If it beats to the right, there will be a boy; if it beats to the left, a girl is to be expected" (recorded from former midwives in Old Believer villages in the Republic of Moldova). In Romanian Dobrudja traditional birth attendees predicted a child's future by birthday or the day of conception:

And babkas said ... that a baby was born on some day or on some holiday, and they read fortune: if the child was born, say, on Annunciation Day - on Annunciation a cuckoo doesn't build a nest - it's a great holiday, and they said if a baby was born on Annunciation Day, they would be happy, but if the conception took place on Annunciation, they would be unhappy. Do you understand? It means a cuckoo doesn't build a nest, but they conceived a baby on Annunciation. They would be unhappy. And there were different ones: they predicted fortune by holidays, by days. ${ }^{7}$

Some midwives in Romania had the gift of providence, the ability to read the fate of the child (Arslanova 2010: 36).

In helping a woman in labor, every midwife knew special massage techniques used to alleviate childbirth pain:

[When you were called to act as a midwife ... and it was bad for her, and she had a hard labor, suffered with childbirth, what did you do to help her?] [CEO:] You need to know the technique, work with your fingers, work with your fingers, you need to help her. ... And how we squeezed them with a towel! [MEA:] And with sheets, not just towels. [CEO:] A big towel, one woman on one side, the other - on the other side. ${ }^{8}$

[And how could a babka help? Was she massaging?] Well, help. She took a towel from here [in the abdomen - N.D.] and squeezed bit by bit, but as the head came out, she began to turn the head a little, and when the arms started to go out, she took them and ... took the baby out. ${ }^{9}$

[Did a babka have any special knowledge?] Nothing, absolutely not. It seemed she only massaged and that's all, nothing more. She fondled the belly a bit here, a bit there, rubbed her legs and hands. But there shouldn't have been earrings, no earrings, and there shouldn't have been any ring on the hand, or any bracelet. ${ }^{10}$ 
As an intermediary between a woman in labor and the higher powers, the birth attendee read special prayers during childbirth. At all the research sites, there is a widespread belief that in order to alleviate childbirth it is necessary to read the canon of the Virgin Fedorovskaya. Midwives accompanied every action by prayers to the Virgin Mother. It is worth mentioning that according to the local beliefs, the future mother had to pray herself, too: first of all, she had to read prayers to the Virgin Mother and Guardian Angel. To make the delivery easier, an icon lamp was lit, but the woman in labor was forbidden to touch it. Across the north-west Black Sea region Old Believers consider Fedorovskaya icon of the Mother of God to help during a difficult childbirth; this belief stands up to the present. In addition to the woman in labor and the midwife, all family members could pray to alleviate childbirth: "Mom told me who had been at home, everyone stood up and prayed ... [To have a good delivery?] Yes, yes, because a lot of women died in childbirth."11

The midwife could take on the functions of a priest and baptize the baby: if it was born weak, she could immerse the baby in the water so that it would not die unbaptized:

[MUN:] It was called immersed by the midwife. When a baby was brought, and it was weak, there ... [DVV:] Yes, yes, yes. [MUN:] ... looked like it would die, and she would do it right in the bucket, and would say: "In the name of the Father and the Son and the Holy Spirit". [DVV:] Yes, yes, and it was considered baptized. [MUN:] Yes, yes. [DVV:] Then they would go to the priest, and he would complete some prayers there, but he did not repeat it. He did not put the baby into the water, which means the baby was immersed in the name of the Holy Trinity. There it was. ${ }^{12}$

[So as the baby would not die unbaptized, could the midwife somehow immerse the baby into the water by herself?] [PSV:] Yes, yes, yes. Yes, I heard something like that too. [SAI:] Yes, yes, in a bucket. A new bucket of water and "I Believe" [a prayer; the canonic name of "I Believe" would be "Nicene Creed", the interlocutor names the prayer by its first words - N.D.], to read three times "I Believe", "Holy God", "I Believe"... Here Natasha was, the deceased sexton's wife, she went. She went, she immersed, it was called "immersed". [PSV:] Immersion. [SAI:] And then, if you didn't manage to baptize, you immersed the baby, and you buried it right after that. [Did they immerse babies three times?] Three times, yes. Natasha went, and such worthy women who prayed to God. Yes, she immersed. And if you didn't manage to immerse, then you didn't bury the baby. [But this way, can it be buried as if baptized?] Yes. Then the priest will add prayers, will read everything. As if baptized. [Did they 
call the baby half-baptized?] No, no. [And if the baby survived, then was it baptized later?] Yes. The priest would complete a bit there. Well, they didn't immerse it in the water, it counted. ${ }^{13}$

As noted by Galina Kabakova, "this precautionary measure is welcomed by both the family and the church, as the infant baptized by the midwife, even in the event of an early death, had the right to a Christian burial. If it survived, the priest completed the baptism" (Kabakova 2001: 117). The cited fragments of the interview show that the Old Believer priest did not immerse the infant for the second time.

The postnatal procedures also performed by the midwife included special actions with the umbilical cord and the afterbirth. The midwife cut the umbilical cord (mothers usually kept a part of it at home):

[And how did she [the midwife - N.D.] cut the umbilical cord?] Just with her scissors. ... Scissors used to sew, to cut the goods. ${ }^{14}$

[What did the midwife cut the umbilical cord with?] Thread. [Thread?] Yes. She would tighten the thread, and then it would fall off itself..$^{15}$

[And who cut the umbilical cord?] Babka. [And with what?] Well, what did she bandage with? I don't know what she was bandaging with. Then she specially wrapped the navel there. I remember my mother... Babushka Anisya delivered them all. So the navel had not fallen off yet, the baby's navel. I remember her tying it with a bandage, she spread some herbs there, put something... well, she knew that. ${ }^{16}$

After the delivery, it was important "to bury" the child's place (placenta, afterbirth) in the ground, to bury it symbolically, because among the Slavs the placenta was traditionally perceived as a twin of the child and/or mother (for more details see Kabakova 2009b: 200). According to Tatiana Listova, among the Russians "there was a belief that through the afterbirth, as well as through the umbilical cord, it is possible to harm a woman in labor and the child. Even the unintentional destruction of it could have a detrimental effect. Therefore, the midwife had to bury the placenta so that no one, neither a person nor an animal, could reach it" (Listova 1997: 508). My interlocutors in the Republic of Moldova and in Romania remember that local midwives buried placenta in the places where no one walked.

Another important function of the midwife was postnatal care of the mother and the newborn. It usually lasted for eight days (less often - three days) and included bathing, rubbing, and, if necessary, treating the mother and the baby: 
Right after the delivery the new mother was given a big glass of wine so that she replenished with blood. ... And after that the babka [took the new mother] to the bath house, and she rubbed her, she came on eight days and washed her in the bathhouse. Eight consecutive days she washed her and her baby. ${ }^{17}$

There were herbs there, in the cast iron those herbs were boiled, one put those herbs under the baby's head, here one took water and poured it from a mug, washed the baby... The babka bathed the baby with a prayer. ${ }^{18}$

According to Alla Galkina and Aleksandr Prigarin, in the Odessa region (southern Ukraine) the babka massaged the baby right after birth. Every day (for three days) she came to the new mother, washed her, rubbed her in the bath, lifted her stomach, looked after the baby (Galkina \& Prigarin 2014: 589).

The responsibilities of the midwife were considered to end with "washing the hands". Local women usually called this rite "seeing the babka off". Memories of this practice were recorded in Sarichioi (Romania):

That babka is then taken to the bathhouse, and she rubs the woman, the new mother. [After giving birth?] Yes, yes, yes. And she would wash the baby and rub it as she knew. And three baths had to be done. And then the babka was given soap, a bar of soap was given, and a towel was given to her. She was given a towel and soap. And money ... [Was it like a gift to her?] Yes. This was when she finished that... When the babka was given water on her hands, and she wiped her hands, washed them and wiped them with the towel you gave her, and the soap was the one you gave her. ${ }^{19}$

Describing the traditions concerning childbirth in Russia (Tambov region), David Ransel noted that "the ceremony of 'washing the hands' and paying the midwife ... and invocations of God's help, together with the control that the village midwife and members of the family exercised, free of the influence of outsiders, endowed the birthing process with a protective intimacy" (Ransel 2000: 128).

It is noteworthy that even after performing the rites of "washing the hands" / "seeing the babka off" new mothers could still address the midwife if they needed help. For instance, in case a woman had no milk to breastfeed her baby, she sought help from the traditional birth attendee. Rural midwives also treated the mother and the baby for the evil eye, prepared evil eye amulets for pregnant women, treated babies for slight illnesses using medicinal herbs and prayers.

Field materials show that after delivering a baby and providing postnatal care, the midwife had to undergo ritual purification. The new mother and the 
baby had to go through it, and all those who could be present at the childbirth or visited the woman before the baby was baptized - during that period the mother and the newborn were considered impure. The midwife was also among these people: local women remembered that after attending a childbirth the babka had to take a prayer from the priest, it was called the purification prayer. The priest would say this prayer. Here I would like to draw attention to the fact that the midwife could take a prayer on the third or eighth day after childbirth, when she had finished the postnatal care of the mother and the newborn, while the woman who gave birth usually went to church with the baby on the fortieth day. Along with the purification prayer, it is called the fortieth prayer. In rare cases, the midwife accompanied the new mother to the church, after having performed the rite of purification.

To sum up, the local midwife's knowledge went far beyond birthing procedures. She acted as a ritual specialist, whom the villagers addressed during the rites of passage (not only birthing, but also funeral rites, as field materials demonstrate), and also performed a number of traditional healer functions. It was in her power to ensure a baby's entrance into the community. In emergency cases, the midwife could take on the functions of a priest: she said prayers to ease pain during labor, and baptized infants born weak to prevent the death of unbaptized children.

\section{EXPRESSING GRATITUDE AND HONORING MIDWIVES}

Traditionally money was not paid for help during the delivery. However, according to Alla Galkina and Aleksandr Prigarin, in Odessa region a local midwife had been given presents and money since the 1930s. Old Believers thanked a babka with soap, a kalach (traditional white ring-shaped bread) and a kerchief; at christening she was given several kalaches, a kerchief, and length of dress fabric (Galkina \& Prigarin 2014: 590). In Romania midwives were presented with money, soap, bread, salt, a piece of fabric, in the village of Carcaliu also matches. The gifts symbolized wishes of purity and well-being to the midwife (Plotnikova 2016: 42-43). As mentioned by Galina Kabakova, until the midwife was fully rewarded, the child symbolically belonged to her (Kabakova 2009a: 84). There was a special day devoted to midwives in the folk calendar, when women would visit the village midwife and bring her gifts, known among Russians in many regions. It was called babii kashki, because the midwife (babka) prepared porridge (kasha) as a treat for her guests. There was also another local variant of the celebration: women prepared porridge and took it together with other presents to the village midwife. The Old Believers of Romanian Dobrudja had 
this celebration on the 14th of January (the day of St. Basil the Great) or during Maslenitsa festival in the villages of the Danube delta (Plotnikova 2016: 46-47). In Aksiniia Krasovski's description of this tradition among the Old Believers in Romania, there is a clarification that women gathered at the midwife's for the first day of St. Basil the Great or Maslenitsa after childbirth (Krasovski 2001: 252). The Old Believers of Bulgaria celebrated the holiday in honor of the midwives on the 14th of January: on this day, all new mothers visited the midwives who had delivered their children, brought them gifts, had a feast (Uzeneva 2008: 177). When describing this holiday among the Old Believers of Romania, Anna Plotnikova pointed out that at the time of her research (in 2006-2013) it only lived in people's memories thanks to older relatives' stories. In the Danube delta, at present the celebration is settled for the midwives' name days (Plotnikova 2016: 49-50). My interlocutors in Moldova and Romanian Dobrudja remembered neither the name of the holiday babii kashki nor such a celebration on St. Basil's Day or Maslenitsa. However, almost all local women told me about visiting village midwives who had delivered their children and giving them presents for their birthdays, sometimes also for children's birthdays (for instance, in Old Believer villages in Moldova).

\section{LOCAL MIDWIVES AND DOCTORS}

In the 1960 s, maternity hospitals appeared at the research sites, and qualified medical care became available. However, the institution of traditional midwives did not recede into the past, but entered into interaction with professional obstetrics. This phenomenon was widespread, characteristic not only for Moldova and Romania. Svetlana Adonieva and Lora Olson paid attention to the fact that "women perceived maternity hospitals as alienating, depersonalizing institutions ... recognizing the need for medical intervention, they continued to seek help from older relatives in search of knowledge about caring for themselves and the baby. In the village, women could go to local old women known for their knowledge" (Olson \& Adonieva 2016: 233). In Old Believers' villages, women had greater confidence in local ritual specialists, since they not only knew the techniques of relieving birth pain, but also knew what prayers should be said during childbirth, they could immerse the baby if necessary, etc., in other words, they knew "tradition".

Recognizing the achievements of medicine, women were not willing to refuse the services of midwives, so they turned to both doctors and traditional birth attendants at the same time: 
There was a hospital, a babka and a doctor. And the babka ... [What did she do?] The babka delivered the baby. And the doctor treated after that, when ... if the child was sick. There were babkas, I witnessed babkas. I brought a girl, in the sixty-third, in January, Tatiana ... [And what did babkas do? They just... did they come when the birth began? Or how?] Yes. And there they were, they sat there - in the hospital, where they gave birth. The babka slept there, and the doctor in this room. ${ }^{20}$

I was a midwife, but I called a doctor. And, on the contrary, they would call a rural midwife to the doctor. A woman came from Poiana the village next to Cunicea - N.D.], and G.I. was absent, she had lunch, one had to go as far as to the forest. And the dentist we had was a man. So what? A woman will give birth. Girls... There were girls there, nurses on duty and junior nurses. All were girls. And he says this: "Babushka E., go to your maternity hospital." There was no junior nurse on duty at that time; there were only two nurses there. Only two were there, and they fell ill, and there was no duty and there were no nurses. And we were, even until then. And there was no junior nurse at all. I went. I went to $S$. and said: "I need help, because," I say, "I ..." And he went out, standing on the threshold, looking at me like that: "Aunt E., honestly, I don't know. Well, forgive me, I am a dentist, we didn't practice this, they didn't take us, they didn't show us anything. I honestly don't know." I say: "As you wish, I will not do it alone. The woman is already giving birth, the waters have already broken." I ran; I didn't talk to him for a long time, because it had already... and he came. And he put on a medical gown and said: "Aunt E., if you know, understand, do it. I will only if, God forbid, I can help you: give injections, something else. And I'm there. What should I do?" And so he stood before me: "What should I do there?" On the table there... And I say: "You stand near me, what I tell you, you will give me." 1

The last fragment of the interview shows that the midwife could act as an obstetrician-gynecologist when state medical institutions were already operating in the villages. In the above interview, the rural midwife performs delivery in a hospital with a dentist at a time when there are no maternity nurses at work. On the other hand, traditional birth attendees recognize the need for more qualified medical care. It can be seen that at this time two institutions traditional midwifery and qualified obstetrics - exist as parallel systems of knowledge and people use both or one of them according to their needs. It results in a gradual distribution of duties: childbirth is attended by trained medical personnel, and the care of a new mother and the baby, as well as the treatment of the newborn, remains the responsibility of the midwife (in rare cases, it is 
the other way round: the midwife delivers the baby and then the doctor treats the woman and the baby, see the example above).

A similar practice of childbirth with the help of traditional midwives and doctors was observed by Elena Arslanova among the Old Believers of the Astrakhan region, who re-emigrated from Romania:

Women who gave birth were cared for by obstetricians and midwives, each according to their own knowledge: "the doctor delivered the baby, the midwife took care of it"... The tasks of the obstetrician included delivering the baby, taking its measurements, weighing it. In the postnatal period, she visited the new mother in order to check whether the navel was not wet. The midwife remained to perform postpartum procedures. (Arslanova 2010: 39)

It is significant that the representatives of official medicine at the research sites did not oppose such a distribution of roles. It was only forbidden to use the services of a midwife without a doctor during childbirth. The struggle against traditional midwifery took place within the framework of the state reorganization of obstetric care practices, which began in Russia in the 1920s, with the foundation of the Department for the Protection of Motherhood and Infancy under the People's Commissariat of State Charity. Nevertheless, during the implementation of this state program, there were no medical facilities at the research sites: women had to call obstetricians to their places or go to the nearest city maternity hospitals. As a result, women in labor did not refuse the help of the local midwives, but concealed that fact:

And she [the babka - N.D.] delivered my baby. She was born to me very big. And then babushkas were forbidden to come. They wanted us to call... doctors, and ... an obstetrician. And we did not have a hospital yet. And then, like, well, a timber house there was, they made one room, and then when they were already there, when they came to me, two of them - like a maternity nurse and one more. They looked and said: "It is not true that you..." I said that I gave birth alone, there was no babushka. And she said: "It's not true, you could not have given birth to her alone. She is so heavy, she weighs," she says, "more than four kilograms. You couldn't have given birth to her alone." 22

It is interesting that in some interviews, local residents not only compared the traditional birth attendee with the doctor, but also called the obstetrician babka. When maternity hospitals opened in the villages, some rural midwives worked there as nurses or junior nurses. In Cunicea (the Republic of Moldova), one of the former midwives told me how her daughter gave birth to a child: they did 
not have time to go to the hospital, therefore the mother (midwife) delivered the baby at home, and then drove the woman to the hospital:

I arrived with her at four in the morning, brought her already. They said: "And who helped to deliver the baby?" I said: "I did!" They came talking. I said: "Girls, faster, the afterbirth did not come out, nothing ..." - "And who," they returned once again, "who helped to deliver the baby?" I said: "I did." - "And who are you?" - "Mother." - "Giiiirls!" The doctor asked this: "Girls, let's get a stretcher faster." They carried her, and at home I prepared a bag for them. What you needed, everything, everything, everything. When I go, I go straight to the hospital - I'm a doctor. And they: "Where are you going?" I say: "Take this bag, have breakfast there. You do everything, then," I say, "have breakfast." And she, the nurse, says: "Could you even also prepare a bag?" I say: "I know, - I say, - I know this. I was, worked in our hospital." Then I began to talk with them. "Well," she says, "that's something! The mother [of the woman in labor - N.D.] delivered the baby and brought, - she says, - breakfast for us. ${ }^{{ }^{23}}$

It can be seen from the above fragment of the biographical narrative that a woman who was a rural midwife began working as a junior nurse in the maternity hospital in the 1960s. She considers herself a doctor, i.e., fits into the system of official medicine. Since the 1980s, the ban on traditional midwifery no longer existed, so home births stopped being hidden. In addition, in the last interview, the form of gratitude of the medical staff is noteworthy: nurses, like the village midwife, were offered food and refreshments as a form of gratitude. My interlocutors often pointed to this analogy themselves.

Let us compare the previous narrative with local women's memories regarding meeting and seeing off the midwife after childbirth:

There was a babka, when she came, a samovar was waiting for her, and with tea, warm wine, and this was for the babka, the treat was for the babka, yes. And she, when it was late or night, or cold, or rain, she did not go home, stayed. And these eight days, although she went home, she came every day. They said: "Today at three o'clock we will heat the bath [bania]." She already knew, she already went at two o'clock. ${ }^{24}$

Right after delivery. The babka washed herself, her hands, the baby was laid, the new mother sat. Here the relatives laid the table, treated her, and the babka was paid, they gave her a present that they had bought. It's like now in the maternity hospital: all the same they give these obstetricians gifts. $^{25}$ 
It should be noted that an important difference between the traditional practice of obstetric care and that of the medical institutions was the connection between the midwife and the children she had delivered. At my research sites in Romania and the Republic of Moldova local women pointed to the connection between a midwife and a child quite literally: it was believed that the midwife brought the baby, therefore she was a part of the future life of the child. Midwives were treated as relatives, they were invited to celebrate children's birthdays; it was customary to give presents to the midwives not only after the childbirth, but also as the child grew older. Traditional birth attendees were thanked not just for technical assistance, but also for the cultural role (Belousova 2003: 365).

The relationship between the doctor who delivered the baby in the hospital and the newborn looks less deep than that between the midwife and the child. However, the situation is not so simple either. Comparing the functions of "a midwife in traditional culture and the functions of an obstetrician-gynecologist in modern urban culture", Ekaterina Belousova argues that doctors feel their important roles in the complex process of giving birth, which requires from them much more than just medical assistance. As "children of their culture", doctors realize key cultural concepts encoding childbirth. Medics actively use "folk methods" in their practice, take into consideration popular beliefs concerning childbirth (for instance, determining the sex of the future child, programming his or her physical and mental development, washing and dressing the baby, constructing norms on how long the new mother has to breastfeed the baby, when the child has to start speaking). Ekaterina Belousova concludes that a typological comparison of actions and statements of doctors with traditional forms of authoritative knowledge suggests that the sociocultural aspect of these actions and statements can be considered even more important than the medical one (Belousova 2003: 358-367).

However, a doctor's help is often not enough: in the villages with Old Believer population, "even today, when women deliver in hospitals, they ask that an older woman come to the bania to wash and massage mother and the newborn" (Crasovschi 2005: 42). This practice is still spread throughout the region (Romania, Moldova, southern Ukraine).

\section{CONCLUSION}

When official medicine began to spread, the institution of midwives was not marginalized, but started competing with it. Many women preferred birthing at home to doing it in rural hospitals. Local midwives not only knew how to relieve physical pain, but remembered appropriate prayers, could serve as priests if 
a child was born weak and needed to be baptized as quickly as possible. When the authorities prohibited the practice of traditional midwifery, local women did not abandon it - they started concealing the fact of giving birth with the help of ritual specialists. But eventually, traditional midwifery, which initially enjoyed great authority in comparison with skilled obstetrics, entered into dialogue with it. This led to a form of coexistence of two legitimate systems of knowledge, in which, at first glance, each of them had a specific role. Women in labor addressed both traditional midwives they trusted and doctors who knew modern medical science. A closer look reveals that it is impossible to draw a clear line between the two systems and institutions (for example, rural midwives worked in hospitals and delivered babies together with doctors), even though the knowledge of a traditional midwife was not limited to birthing practices and she performed many more functions than an obstetrician. Nowadays women prefer official medicine and equipped hospitals. However, long-term parallel use of the services of obstetricians and ritual specialists is still reflected in modern birthing practices in Old Believer communities (transferring interaction models with a midwife to communication with a doctor; treatment of a mother and a newborn for slight illnesses by the former rural midwife, who can also cure the evil eye or share methods of protection from this misfortune). As for obstetricians in modern medical institutions, they also use vernacular knowledge and do more than just provide women in labor with medical assistance.

\section{ACKNOWLEDGEMENTS}

The article was written on the basis of the RANEPA state assignment research program.

\section{NOTES}

1 Online database of folklore and ethnographic data, "Birth-Christening Rites of Old Believers of the North-west Black Sea Region", available at http://eurasianphonology. info/static/childbirth/childbirth_index_location.html (last accessed on 21 September 2020). The elaboration of the digital archive was funded by RFBR, project number 16-36-60024 mol_a_dk.

${ }^{2}$ Recorded in the village of Jurilovca, Romania, from REI, born in 1953.

3 Recorded in the village of Dobrudja Veche, Republic of Moldova, from IER, born in 1926. 
4 Recorded in the village of Dobrudja Veche, Republic of Moldova, from IER, born in 1926.

5 Recorded in the village of Jurilovca, Romania, from REI, born in 1953.

6 Recorded in the village of Jurilovca, Romania, from REI, born in 1953.

7 Recorded in the village of Jurilovca, Romania, from REI, born in 1953.

8 Recorded in the village of Cunicea, Republic of Moldova, from CEO, born in 1940, and MEA, born in 1951.

9 Recorded in the village of Cunicea, Republic of Moldova, from CAE, born in 1931.

${ }^{10}$ Recorded in the village of Dobrudja Veche, Republic of Moldova, from IER, born in 1926.

${ }^{11}$ Recorded in the village of Dobrudja Veche, Republic of Moldova, from HTA, born in 1950.

${ }^{12}$ Recorded in the village of Sarichioi, Romania, from MUN, born in 1942, and DVV, born in 1948 .

${ }^{13}$ Recorded in the village of Cunicea, Republic of Moldova, from SAI, born in 1947, and PSV, born in 1951.

${ }^{14}$ Recorded in the village of Jurilovca, Romania, from REI, born in 1953.

${ }^{15}$ Recorded in the village of Cunicea, Republic of Moldova, from CAE, born in 1931.

${ }^{16}$ Recorded in the village of Cunicea, Republic of Moldova, from SAI, born in 1947.

${ }^{17}$ Recorded in the village of Jurilovca, Romania, from REI, born in 1953.

${ }^{18}$ Recorded in the village of Cunicea, Republic of Moldova, from SAI, born in 1947.

${ }^{19}$ Recorded in the village of Sarichioi, Romania, from SPI, born in 1953.

${ }^{20}$ Recorded in the village of Sarichioi, Romania, from MH, born in 1942.

${ }^{21}$ Recorded in the village of Cunicea, Republic of Moldova, from CEO, born in 1940.

${ }^{22}$ Recorded in the village of Cunicea, Republic of Moldova, from CAE, born in 1931.

${ }^{23}$ Recorded in the village of Cunicea, Republic of Moldova, from CEO, born in 1940.

${ }^{24}$ Recorded in the village of Jurilovca, Romania, from REI, born in 1953.

${ }^{25}$ Recorded in the village of Cunicea, Republic of Moldova, from SAI, born in 1947. 


\section{REFERENCES}

Arslanova, Elena 2010. Obriady zhiznennogo tsikla staroobriadtsev-lipovan Astrakhanskoi oblasti (rodil'no-krestil'nye i pokhoronno-pominal'nye). [Rites of the Life Cycle of Old Believers-Lipovans of Astrakhan Oblast' (Birth-Christening and Funeral).] Monograph. Astrakhan: Izdatel'stvo Sorokin R.V. Available at http://russkayasvyaz.ru/wp-content/uploads/2015/10/Книга-Пауновой.pdf, last accessed on 22 September 2020.

Belousova, Ekaterina 2003. Rodil'nyi obriad. [Birth Rite.] In: Aleksandr Belousov \& Inna Veselova \& Sergei Nekliudov (eds.) Sovremennyi gorodskoi fol'klor. Moscow: Rossiiskii gosudarstvennyi gumanitarnyi universitet, pp. 339-369.

Crasovschi, Axinia 2005. Russian Old Believers (Lipovans) in Romania: Cultural Values and Symbols. In: Irina Vainovski-Mihai (ed.) New Europe College Yearbook 20012002. Bucharest: New Europe College, pp. 17-59. Available at http://docplayer. fr/2290170-New-europe-college-yearbook-2001-2002.html, last accessed on 21 September 2020.

Dushakova, Natalia 2018. Rodil'naia obriadnost' staroobriadtsev Severo-Zapadnogo Prichernomor'ia: aktual'nye vernakuliarnye predstavleniia i praktiki. [Birth Rites among the Old Believers of the North-West Black Sea Region: Current Vernacular Beliefs.] Etnograficheskoe obozrenie, No. 3, pp. 133-150. https://doi. org/10.7868/S0869541518030107.

Galkina, Alla \& Prigarin, Aleksandr 2014. Russkie. [Russians.] In: Anton Kisse \& Aleksandr Prigarin \& Vladimir Stanko (ed.) Budzhak: istoriko-etnograficheskie ocherki narodov iugo-zapadnykh raionov Odesshchiny. [Budzhak: Historical and Ethnographic Essays on the Peoples of South-West Odessa Region.] Odessa: PostScriptUm - SMIL, pp. 555-602. Available at https://yadi.sk/i/ QGt1nLT1xP3bQ, last accessed on 22 September 2020.

Ipatiov, Filip 2001. Ruşii-lipoveni din România: Studiu de geografie umană. [Russian Lipovans from Romania: Studies in Human Geography.] Cluj-Napoca: Editura Presa Universitară Clujeană.

Jordan, Brigitte 1997. Authoritative Knowledge and Its Construction. In: Robbie E. DavisFloyd \& Carolyn F. Sargent (eds.) Childbirth and Authoritative Knowledge: Crosscultural Perspectives. Berkeley \& Los Angeles \& London: University of California Press, pp. 55-79. https://doi.org/10.1525/9780520918733-003.

Kabakova, Galina 2001. Otets i povitukha v rodil'noi obriadnosti Poles'ia. [Father and Midwife in the Birth Rites of the Polesie Region.] In: Ekaterina Belousova \& Sergei Nekliudov (eds.) Rodiny, deti, povitukhi v traditsiiakh narodnoi kul'tury. Moscow: Rossiiskii gosudarstvennyi gumanitarnyi universitet, pp. 107-129. Available at https://www.booksite.ru/fulltext/rodiny/text.pdf, last accessed on 22 September 2020.

Kabakova, Galina 2009a. Posled. [Placenta.] In: Nikita Tolstoi (ed.) Slavianskie dreunosti: etnolingvisticheskii slovar. Vol. 4. Moscow: Mezhdunarodnye otnosheniia, pp. 200-202.

Kabakova, Galina 2009b. Povitukha. [Midwife.] In: Nikita Tolstoi (ed.) Slavianskie drevnosti: etnolingvisticheskii slovar'. Vol. 4. Moscow: Mezhdunarodnye otnosheniia, pp. 82-84. 
Krasovski, Aksiniia 2001. Obriady, obychai i verovaniia russkikh lipovan, sviazannye s rozhdeniem i kreshcheniem. [Rites, Customs and Beliefs of Russian Lipovans Concerning Birth and Christening.] In: Andrei Ivanov \& Svetlana Moldovan \& Angara Niri (eds.) Kul'tura russkikh staroobriadtsev $v$ natsional'nom i mezhdunarodnom kontekste. [Culture of Russian Old Believers in National and International Context.] Vol. 3. Bucharest: Kriterion, pp. 250-256.

Lefèber, Yvonne \& Voorhoever, Henk 1997. Practices and Beliefs of Traditional Birth Attendants: Lessons for Obstetrics in the North? Tropical Medicine and International Health, Vol. 2, No. 12, pp. 1175-1179. https://doi. org/10.1046/j.1365-3156.1997.d01-219.x.

Listova, Tatiana 1997. Obriady i obychai, sviazannye s rozhdeniem detei: Pervyi god zhizni. [Customs and Rituals Associated with the Birth of Children: The First Year of Life.] In: Vadim Aleksandrov \& Irina Vlasova \& Ninel' Polishchuk (eds.) Russkie. Moscow: Nauka, pp. 499-516. Available at https://www.booksite.ru/ fulltext/rus/sian/231.htm, last accessed on 22 September 2020.

Litvina, Natalia 2018. Staroobriadcheskie obshchiny Respubliki Moldova. [Old Believer Communities in the Republic of Moldova.] Pomorskii Sever, 20 November. Available at https://protopop-avvakum.ru/staroobryadcheskie-obshhinyrespubliki-moldova/, last accessed on 22 September 2020.

Naumescu, Vlad 2016. The End Times and the Near Future: The Ethical Engagements of Russian Old Believers in Romania. Journal of the Royal Anthropological Institute, Vol. 22, No. 2, pp. 314-331. http://dx.doi.org/10.1111/1467-9655.12379.

Oakley, Ann 1984. The Captured Womb: A History of the Medical Care of Pregnant Women. Oxford: Basil Blackwell.

Olson, Lora \& Adonieva, Svetlana 2016. Traditsiia, transgressiia, kompromiss: miry russkoi derevenskoi zhenshchiny. [Tradition, Transgression, Compromise: Worlds of a Russian Village Woman.] Moscow: Novoe literaturnoe obozrenie.

Plotnikova, Anna 2007. Chestvovanie povitukhi v russkikh selakh na Balkanakh. [Celebration in Honor of Midwife in Russian Villages in the Balkans.] In: Tatiana Nikolaeva (ed.) Terra Balkanica / Terra Slavica. K iubileiu T. V. Tsiv'ian. Balkanskie chteniia 9. Moscow: Institut slavianovedeniia rossiiskoi akademii nauk, pp. 113-117. Available at https://inslav.ru/images/stories/pdf/2007_ Balkanskie_chtenija_9_Terra_Balkanica_Terra_Slavica.pdf, last accessed on 22 September 2020.

Plotnikova, Anna 2016. Slavianskie ostrovnye arealy: arkhaika i innovatsii. [Slavic Island Areas: Archaism and Innovations.] Moscow: Institut slavianovedeniia rossiiskoi akademii nauk. Available at https://inslav.ru/sites/default/files/editions/2016_ plotnikova.pdf, last accessed on 22 September 2020.

Prygarine, Olexandre 2004. Les "vieux-croyants" (Lipovane) du delta du Danube. Ethnologie Française, Vol. 34, No. 2, pp. 259-266. Available at http://www. ethnologie-francaise.fr/numero/?numero=ETHN_042, last accessed on 22 September 2020.

Ransel, David L. 2000. Village Mothers: Three Generations of Change in Russia and Tataria. Bloomington \& Indianapolis: Indiana University Press.

Rouhier-Willoughby, Jeanmarie 2003. Birth Customs: Ancient Traditions in Modern Guise. The Slavic and East European Journal, Vol. 47, No. 2, pp. 227-250. http:// dx.doi.org/10.2307/3219945. 
Shchepanskaia, Tatiana 1994. Mir i mif materinstva. Sankt-Peterburg, 1990e gody. (Ocherki zhenskikh traditsii i fol'klora). [Maternity: Its World and Mythology (Feminine Traditions and Folklore in St. Petersburg of the 1990s.] Etnograficheskoe obozrenie, No. 5, pp. 15-27. Available at http://journal.iea.ras.ru/ archive/1990s/1994/no5/Schepanskaya_1994_5.pdf, last accessed on 22 September 2020.

Stoianova, Galina \& Trotsyk, Alla 2006. Spetsifika poslerodovogo tsikla u lipovan. [Specificity of the Postnatal Ritual Cycle among Lipovans.] Lipovane: istoriia i kul'tura russkikh staroobriadtsev, Vol. 3, pp. 151-154. Available at http://oldbelivers.com/ download.php?id=29910462, last accessed on 22 September 2020.

Trotsyk, Alla 2005. Povitukha v staroobriadcheskoi obshchine na Dunae. [Midwife in an Old Believer Community on the Danube.] Lipovane: istoriia i kul'tura russkikh staroobriadtsev, Vol. 2, pp. 155-156. Available at https://samstar-biblio.ucoz.ru/ publ/132-1-0-573, last accessed on 22 September 2020.

Tudose, Pavel 2015. Ruşii lipoveni din România - istorie şi actualitate. Comunitatea ruşilor lipoveni din Brăila - model de conviețire multietnică în context național şi European. [Russian Lipovans from Romania - History and Contemporaneity. The Community of Russian Lipovans from Braila - a Model of Multiethnic Cohabitation in National and European Context.] Bucharest: Editura C.R.L.R.

Uzeneva, Elena 2008. Obriady semeinogo tsikla staroverov Bolgarii. [Family Cycle Rites of the Old Believers of Bulgaria.] In: Leonid Kasatkin (ed.) Russkie staroobriadtsy: iazyk, kul'tura, istoriia: sbornik statei $k$ XIV Mezhdunarodnomu s"ezdu slavistov. Moscow: Iazyki slavianskikh kul'tur, pp. 171-183.

Vlaskina, Tatiana 2009. Osnovnye kharakteristiki kul'tury materinstva i detstva u kazakov-nekrasovtsev. [The Main Categories of the Nekrasov Cossacks' Culture of Motherhood \& Childhood.] Vestnik Iuzhnogo nauchnogo tsentra RAN, Vol. 5, No. 3, pp. 69-75. Available at http://www.ssc-ras.ru/files/files/Vectnik_UNZ_3_ Vlaskina_69-75_.pdf, last accessed on 22 September 2020.

Zakharchenko, Galina 2004. Ritualy, soprovozhdaiushchie rozhdenie detei v lipovanskoi traditsionnoi kul'ture Pridunav'ia. [Rituals of Child Birthing in the Lipovan Traditional Culture of the Danube Area.] Lipovane: istoriia i kul'tura russkikh staroobriadtsev, Vol. 1, pp. 115-118. Available at http://oldbelivers.com/content. php?page=etzncgmj_rus\&id=20, last accessed on 6 October 2020 .

Zakharchenko, Galina \& Petrova, Elena 2005. Pervyi god zhizni v narodno-religioznoi praktike lipovan. [The First Year of Life in Folk and Religious Practice of Lipovans.] Lipovane: istoriia i kul'tura russkikh staroobriadtsev, Vol. 2, pp. 157160. Available at http://oldbelivers.com/content.php?page=etzncgmj_rus\&id=20, last accessed on 22 September 2020.

Natalia Dushakova $(\mathrm{PhD})$ is a Research Fellow at the Russian Presidential Academy of National Economy and Public Administration, Moscow (Russia). She is a member of the Commission for the Studies of Old Believers at the International Committee for Slavic Studies. Her main research areas are anthropology of religion and memory studies. Since 2008 she has been conducting field research in Old Believer communities in the north-west Black Sea region. 


\title{
TAKING HOLD OF THE FUTURE: ACTIVE CHILDBIRTH PRACTICES AND BELIEFS IN ROMANIA (IN THE HOME COUNTRY AND IN MIGRATION)
}

\author{
Adina Hulubaş \\ Senior Research Fellow, PhD, Department of Ethnology \\ "A. Philippide" Institute of Romanian Philology \\ Romanian Academy, Iaşi Branch, Romania \\ adina.hulubas@gmail.com
}

\begin{abstract}
The relatively recent urbanization process in Romania allowed traditional knowledge to be transmitted, despite industrialization and technology diffusion. Childbirth is still a mysterious event, and magic thinking fills in the gaps of science in order to keep parents confident and at peace. Taboos are obeyed after birth and before christening, only to reach the phase when the future can be moulded: specific elements are chosen for the ritual bath, the child has to touch several objects that would make them smart, a good singer, etc. A year later, their future occupation will be predicted in a specific ceremony. All these active practices are found in urbanites' families, and also in Romanian immigrant communities in Western Europe. Rituals are mostly compared to neighbouring countries, but also to other distant cultures that show striking similarities. This large geographical spread indicates Indo-European synergies. The identical form of the post-liminal practice of haircutting in Eastern Europe and the Asian rite of passage have not been previously dwelt upon, and it implies the existence of traditional thinking universalia.
\end{abstract}

Keywords: birth customs, magic thinking, migration, rites, superstitions

\section{INTRODUCTION}

Being with child still tests the human ability to master tranquillity in the face of unpredictable outcomes. The traditional worldview helps the future parents considerably. Societies that have recently experienced urbanization (like Romania, where intense internal migration started in the 1960s due to forced industrialization) managed to maintain active magic practices despite the loss of traditional context. It is typical not only for childbirth, but for other situations, too. One can easily observe elements that speak about a former 
rural education in cities. Daily superstitions, such as to avoid hugging someone on the threshold or take the garbage out only when there is sunlight, are rather common. The taboos are often obeyed without the need to understand their significance, the fact that they were transmitted by the elders being more than enough for urbanites. The doorway has been perceived as a sacred space in many ancient cultures of the world, and the resident deities should not be offended by people. Contact with this place in the house is only permitted in ceremonial contexts. As for the trash that should not be disposed of at night time, it represents the well-being of the family, its wealth, and all will be lost in the dark, never to return again.

Recent interviews with 31 Romanian immigrants from Italy and Spain, recorded as part of a project $^{1}$ on their acknowledged identity after arriving in their respective host countries, revealed that traditional gestures are performed abroad, too (some individuals even risk being fined, but they continue to take the garbage out before sunset). Even more so, the rites of passage, such as giving birth or getting married, are more strictly followed in the attempt to assert one's cultural identity.

Traditional codes for life events prove themselves persistent in Slavic regions, too:

The political, social, cultural, and daily life of an ordinary urban Ukrainian is explained by members of the community not through natural causes, but through traditional understanding of the way things happen: if your husband has left you, you must look for the white witch who will help you to win him back; if you are frequently sick, you must look for the black witch who is making you sick. People sincerely believe in superhuman (demonic) influences in their lives, and try to protect themselves with the help of traditional knowledge. (Golovakha-Hicks 2008: 43)

In the case of childbirth practices, folk knowledge managed to fight both against the challenge of uncertainty and against negative states of mind, which might affect pregnant and parturient women. Customs, taboos, and magic gestures that are still performed by Romanians are successful in creating a self-induced confidence in future events. E.G.V. has lived in Rome for the past 20 years and she stressed the fact that all rites pertaining to birth have been enacted "exactly as in Romania". Moreover, she explained why she followed through with customs in clear psychological terms: "It gives you a guarantee, and you are at peace that you did everything for your child to be well." The ontological process of having children reveals itself as "an intimate and complex transaction whose topic is psychological and whose language is cultural" (Jordan \& Davis-Floyd 1993 [1978]: 3). In the following sections I investigate such traditional codes used to pre-set the course of events for a new member of the community. 


\section{FIELDWORK AND THEORETICAL BASIS}

Ethnographic data comes from three different types of fieldwork: the most recent interviews (with a semi-directive approach based on a 35-question questionnaire) were recorded between 2017 and 2019 in Rome, Italy, and Iaşi, Romania. Romanian immigrants who stayed in their destination countries for periods ranging between 7 and 28 years shared their life stories and reckoned the importance of cultural heritage in the effort of adaptation. Previously, three interviews were held in Romania with emigrants to Italy, Spain, and Greece, the latter having decided to remain in her home country for good. The second type of data is also recorded in urban settlements. A post-doctoral project (implemented from 2011 to 2013) allowed me to investigate socio-cultural patterns that characterize migrants and their reaction to the surrounding world when it comes to childbirth customs. The respondents were 23 urbanites, and their responses were compared with information gathered from their friends and family who never left the villages.

The dynamics of customs and beliefs could not be understood properly without a clear image of their initial rural form. The Folklore Archive of Moldavia and Bucovina, founded in 1970, provided the analysis with a rich amount of data on childbirth that I classified and discussed in a book (Hulubaş 2012). All these milestones guided the conclusions on the role played by traditional knowledge in the present-day struggle, since I used the same questionnaire for rural and urban settlers and improved on it for the discussions with immigrants. The same districts that are covered by archived data were investigated for a post-doctoral project, and the majority of the immigrants came from these parts of Moldavia (a north-eastern region of Romania). While in 1970 recording was made on the tape-recorder tape, modern devices were used in 2011 and present-day interviews.

Scholars agree on the fact that the social birth of the child doubles the biological one (see, e.g., Laderman 1984: 549; Pop \& Ruxăndoiu 1978 [1976]: 189; Kabakova 2000: 90; Bartoli 2007: 236; Mathole \& Shamu 2009: 209; Crețu 2014: 85). The "experience is socially constructed" (Liamputtong 2009: 175) and much effort is put into achieving the best qualities for the individual to be easily accepted and even treasured by the community they are part of. "Integration rites and ceremonials" seem to dominate childbirth customs (Pop \& Ruxăndoiu 1978 [1976]: 183), but the coming into the world has in fact three clearly delimited phases. The first is obviously biological and it is defined in Arnold van Gennep's terms (1960 [1909]) by liminal rites. The second birth is spiritual and it consists in the Christian baptism where the entire body of the child aging around 40 days is submersed in water to symbolize the death of the heathen being and the appearance of a new, superior individual. The godmother 
and the godfather, whose selection is based on their moral qualities, assist in this becoming. Therefore, the social birth is the last to take place, also by the hands of the godmother who will mould the profile of the baby, as seen below, in the last section of the paper. Both the spiritual and social beginnings are part of post-liminal rites.

\section{THE WOMB OF TOMORROW: REGULATION OF THE PREGNANT WOMAN'S BEHAVIOUR}

Before any of this could happen, pregnancy has to be completed with a high level of consciousness on what is harmful and what is a good omen for the unborn child. The future mother is highly receptive to the world around her, and there are two types of influences that she needs to manage: the spontaneous, negative ones, cast by people and supernatural entities, and the intentioned positive actions performed by her or members of the community. While the first ones impose an apotropaic reaction, the second ones focus on symbols that augur well (Hulubaş 2014: 117).

As research showed, the former, negative category is still present in the minds of urbanites and immigrant mothers. Three women who experienced their pregnancy abroad declared that they avoided looking at ugly sights or disabled people for fear their child will turn up alike. One of them even used a specialized formula against this unwanted contagion: "Tu ca tini, copilu' meu ca mini!" (Be as you are, let my child be like me!). According to the records of the Folklore Archive of Moldavia and Bucovina, the precaution of staring at less fortunate people with an unpleasant appearance has been documented in all villages. However, this apotropaic saying has only been found in Tansa, in the same district that represents the native place of one of the interviewees. Iaşi is also the present settlement of S.T., an urbanite that indicated this precise formula as a way to ward off the danger of giving birth to a child that resembles the uncanny person that startled her. The conviction is common throughout the world. Lise Bartoli noted similar beliefs in Sri Lanka, Cameroon, Madagascar, and Turkey, where pregnant women constantly look away from ugly people and are in search of the beautiful ones (Bartoli 2007: 93).

Immediately after birth, the child may become an object of negative attention. The fear of being overlooked (Rom. deocheat) worries most of the new mothers from towns situated in and outside Romania. Tying a red thread around the baby's wrist is one of the common ways to divert the gazes of people around both in Romania and in Polesie, where a red woollen thread was tied to the child's right hand (Tolstaia 2009: 234). T.C. and C.T. trusted this strategy and 
used it for their children who were brought up in Rome. The urbanite mothers S.G. and M.G. declared that such an accessory is mandatory for the newborn, while C.T. from Italy explained this measure under the authoritative label of transmitted knowledge: "I do it because this is how it is done, that is the way tradition wants it". The motivation is similar to what urbanites in Romania answered to the questions on how they learned about customs and why they continue to observe them. Numerous phrases contained the word elders as a supreme argument for the necessity and efficiency of traditional practices (Hulubaş 2014: 53).

The fact that your grandparents taught you something is more than enough for the perpetuation of gestures and rites; it simply excludes any other quest on the meaning, and this reaction is mostly represented in a specific type of community: "the oral tradition of a folk society has no check or competitor" (Redfield 1947: 296). G.D. lived in Torino for 13 years and decided to return to Romania in 2013. When I asked her why she observed certain taboos she answered in the same manner rural inhabitants do, by stressing the infallible cultural system: "This is what I heard [that has to be done], I know it is good [to do it], if that is what she [her grandmother] taught me...". M.A., an urbanite from Focşani, ended her life story proving that superstitions are helpful with the following words: "What is learned from our elders... [is always true]".

The good looks of the unborn baby are also kept in mind when it comes to stealing various things. All rural and urban respondents were familiar with the superstition that the shape of an object stolen while being pregnant will appear as a birthmark on the child's body in the same place the mother touched herself after stealing. E.C. lives in Rome and she was fully aware of this interdiction when she brought her twins into this world. The same precaution was respected by M.N. in Spain. "The fundamental principle is that by creating some definite magic analogy the desired object or event is simultaneously assured in reality. Basically, the image and the reality consequent on it are magically identical" (Werner 1980 [1926]: 365). Some time ago in Moldavian villages future mothers would make use of the stealing taboo and take wood shavings from carpenters without permission, in order to have curly-haired babies. They placed them in their bosom to obtain contagious magic (Hulubaş 2012: 176).

Practices that augur well for the baby-to-come have not been found today in interviews carried out in Italy or with the emigrant who turned home for good from Greece. Archived documents indicate that a few decades ago pregnant women used to stare intentionally at beautiful people and to comb their hair on the threshold in order to magically gain the pleasant appearance of their children (Hulubaş 2012: 176). Therefore, the environment used to be carefully mapped for bad and good omens and people knew that on the one hand, "being 
pregnant means one's freedom of body and mind: every gesture, every word spoken, every movement of a pregnant woman also involves the child" (Gélis 1991: 66); on the other hand, unseen forces can be manipulated for the benefit of the mother and her child.

\section{IN THE HANDS OF GODPARENTS: BAPTISMAL RITUAL AND THE FIRST BATH}

Both the spiritual and social birth have to be mediated by people who have proved worthy of being godparents. Their moral profile and social position are essential for the well-being of the child, since it is believed that they will follow their steps. The relationship created by baptism is rather magic since urbanites, like rural inhabitants, are convinced that babies will grow to resemble their godparents. Hence, they have to be "well off, lucrative people, not just anybody", as P.T. declared. Romanian immigrants always choose people coming from their country of origin, a preference that is present in all the rites of passage performed abroad: the wedding sponsors and the recipients of alms have to be Romanians, since other nationalities "do not understand these things", as several immigrants declared.

Social organization around the event of childbirth as an institution has already been noted in relation to the role of empirical midwives by Mongeau, Smith and Maney (1961: 498). Moreover, the Romanian customs create a hierarchy that places godparents on top, since it is forbidden to ever upset them or to have an argument with them. Unlike in the English language, the relationship between the parents and the godparents is defined with a special word that means "with the mother". Cumătri comes from Latin com and mater, and has equivalents in other Romance languages: comare in Italian, comadre in Spanish, commère in French. So they are just as involved in raising the baby as biological parents, but before that they get to mould the child's future through Christian baptism and the following ritual bath. In Guatemala the traditional birth attendant is called comadrona, and 49 percent of labours were still assisted by them at the end of the past century (Callister 1998: 290). So, linguistically speaking, the godmother and the midwife share the same function, since both are "with the mother". Furthermore, in Romania the midwife used to baptize the newborn and became its godmother if the baby was weak at birth and there was a chance it might die.

The ATU classification of tales reflects the importance of choosing righteous spiritual parents under type number 332: Godfather Death. In these texts, man selects a sponsor who treats everyone alike - Death. Romanian variants grant 
a feminine gender to this character, proving once more that the woman bears a more complex ritual role: Moartea cumătră (Godmother Death). Such a tale recorded in Straja, Suceava, in 1977, is even more striking since the new father refuses God himself and also Saint Nicolaus, for they are not "fair men": they allow some people to be wealthy, others to be poor, some are made beautiful, others ugly, and so on. Death, on the contrary, comes to the young and the old, the rich and the poor in an equal manner, and therefore it is "a righteous person" (Hulubaş 2012: 378), suitable to baptize the newborn.

During the religious service the godmother has to hold the baby on her right arm, according to numerous statements archived in the database mentioned above. The same belief is encountered when it comes to the first time the baby is breastfed: it has to suckle from the right breast in order to be right-handed and to be treated right in life. The belief is common in all Slavic areas where explanations vary from avoiding the risk of becoming left-handed to warding off the possibility of growing into a person with evil eyes (Tolstaia 2009: 235).

This spatial choice was acknowledged by three of our urbanite respondents and it is part of an imagery that divides the surroundings into two opposite categories: right is associated with positive characteristics, whereas left refers to their opposite. While Slavic people share the same antagonism of the space visible in everyday life and in the rites of passage (Tolstaia 2009: 233), Mara Mabilia discussed such implications at a distant population, in Tanzania, proving that beliefs are built on a perceptive universalia: "the east, the south, above, men, the right hand, light, fertility and life; and on the other, the west, the north, below, women, the left hand, darkness, sterility and death" (Mabilia 2007 [2005]: 28).

From baptism to the ritual bath given to the baby on the next day, the godmother gets to write the baby's fate through her gestures. Both submersions are "rites of incorporation" (Gennep 1960 [1909]: 54), and social acceptance follows the religious service. Twenty-four hours after the Orthodox baptism, friends and family are expected to gather again to witness the godmother wash up the child. It is fairly important that she is thorough during this bath, because it is supposed to influence the level of cleanness in the child's life, the way they will smell and clean themselves. R.I. and M.T. indicated this in the interview recorded in Rome, saying that "the baby will be just as clean as their godmother makes them", and several urbanites told personal stories about improper washing. M.A.'s son was not bathed well, apparently, and he now suffers from a skin condition on his head. Magic thinking was transmitted to him as, according to his mother, he often says: "Oh, mother. My godmother... I'm going back to her to wash my hair again, not to have crusts on my scalp".

The attention paid to the neatness of clothing is also essential. Urbanite S.T. explained all the steps that echo back after some time: 
You have to wash them little by little, as they say... all over the body, you must not miss any spots on the child's body, you wash them with the corner of the baptism cloth and soap, and blow gently over them with basil. If she doesn't dress them properly, and this is another issue, there has to be no wrinkle in their clothes, all set up and unfolded ... Everything they wear shouldn't be wrinkled or tight on their body, they have to be dressed properly, because this is how they will dress when they grow up.

These clothes represent the second one out of the three gifts (consisting in an entire outfit for the baptized baby, in both cases) that the godparents have to make. The last one is given when the child turns one and a haircut has to be performed. The clothes seal the connection between them and the child (Văduva 1997: 97).

It is compulsory to put the water in the tub in just one pour. If it is too hot people wait for it to cool on its own, because adding cold water would result in misfortune: the child ends up having two marriages when they grow up. This belief is widely spread in villages in Moldavia (Hulubaş 2012: 201-202) and was also mentioned by two immigrants in Rome. Everything that comes in contact with the new baby is decisive for their future.

Initially scăldătoarea (the bath) was a women's gathering only, and the midwife was the one to prepare ritual ingredients. Today, men also attend this event, together with the godfather who holds the lit baptismal candle as long as the washing takes place. Hence, not only the baby becomes the beneficiary of symbolic gestures and objects, but also the group reinforces the bonds: "A ritual is not just a pattern of meaning; it is also a form of social interaction" (Geertz 1957: 52).

The bathtub also contains the cloth used during baptism (Rom. faşa) and a large number of ingredients intended to influence the future of the child on a magic level. They can be divided into four types of symbols: elements that bring good health, some others for beauty, objects improving the child's abilities placed under the tub, and wealth-implying ingredients.

The ritual was performed or witnessed by nineteen of the interviewees abroad. Nine of them stressed that the ritual bath was organized just the way it is done in Romania, and one even offered the word home (Rom. ca acasă) for this comparison. Rituals are not exposed to change or oblivion at the first generation of migrants, a conclusion that became obvious also during interviews with urbanites. And if we introduce the third element of comparison - the rural practice - into this picture, it is safe to say that little difference can be noticed between the choices made by immigrants for the ritual bath and the traditional content, even though no less than five decades have passed since the first recording of such events for the Folklore Archive of Moldavia and Bucovina. 
Basil is the most common ingredient for the second ceremony, and this is what documents from the Folklore Archive of Moldavia and Bucovina also indicate (Hulubaş 2012: 257). One respondent indicated the precise meaning of this ingredient - basil will bring good luck (Rom. noroc) throughout the child's life. The other respondents did not know the specific motivation. C.T. reacted in a slightly irritated manner to my insistence on learning the significance of each magic element she added to the bathing water: "I don't know what to tell you. I know it is good to have them put inside, but to tell you exactly what each and every one means..." Once again, knowledge of cultural heritage is enough; one does not need to know the purpose of the rituals, the feeling of safety induced by them suffices.

Health is magically attracted by adding a beaten egg to the water, along with milk. Both these products nourish the skin, so their immediate effect is visible. The egg will continue to function as a symbol during childhood so that the baby will be healthy / whole like an egg is. The birthday grab, organized when the baby turns one year old, presents the child with various objects, as is discussed in the following section, and egg is one of them. In villages the child takes the first steps by following a rolling egg on the floor. In fact, the egg is a prominent symbol during all rites of passage (Ciubotaru 2012: 108-120), given its mythology. Milk is associated also with feminine charms in Christmas carols (Brătulescu 1964: 167) as well as with good health and rebirth, the latter being a part of liminal rites such as the wedding day. In ATU 425A fairy tales, The Animal as Bridegroom, the bride is taking a bath in milk to prepare herself for the life that she is about to experience. Moreover, in some other fairy tales, horses transform themselves from runts to winged stallions by being bathed in milk (Teodorescu 1996: 43). Bread used to be added to the bathing water, too. I only found it mentioned by three urbanites from Iaşi, but it was common for the majority of villages in Moldavia (Hulubaş 2012: 251). Along with milk, home-made bread is often a ritual gift in childbirth customs (during the first visit to the newborn, it was given to the midwife for her services, colacii (kneaded bread) for the godparents, etc.) and all rites of passage. Immigrants, for example, confirmed that brides still go through a ritual that consists in having a special loaf of bread broken above their head by their confirmation sponsors. These food items "with a noteworthy positive symbolism reveal the accent placed on spiritual meanings of the gift, in the patterns of traditional life" (Văduva 1997: 71).

Beauty is the second aim that is magically pursued according to folk convictions. Flowers or petals, more exactly rose petals, have often been indicated both by immigrants and urbanites (Fig. 1). The child will bloom like the flowers and smell like them, too. But it is not enough to have beautiful features, one has to 
be attractive to gain social visibility, hence women add honey or sugar in the water. The baby will grow to be sweet, as many informants explained, meaning that everybody will be fond of him/her. The ingredients mentioned above and all the following ones used to be added in the first bath that cleansed the baby after expulsion. A ritual text gave the codes for symbols: the child will become "precious as silver / sweet as honey / good as bread / healthy as an egg / rosycheeked as a peony / attractive as basil / and white as milk" (Marian 1995: 58). Feathers are also used to obtain lightness of movement.

Another type of food - rice grains - is also put in the bath according to three immigrants. Its purpose is to acquire wealth, as urbanite M.D. explained: "Just as a rice grain expands a lot and it is useful, the child will thrive a lot and get help". More objects bringing good fortune in life are represented by money and gold.

Being oriented towards the future, the act performs the function of a wish; the magic objects used during these rites are selected in accordance with a comparisons system that connects them with fundamental aspects of the child's status, behaviour, and destiny. (Pop \& Ruxăndoiu 1978 [1976]: 184)

Future abilities were vivid in the mind of the midwife and they were suggested to the newborn right after birth. The baby was put lying on a book, notebooks, and pencils, or a tool was given in its little hand or a pencil, to allow him or her to be good at a certain job when they grow up (Hulubaş 2012: 197-198).

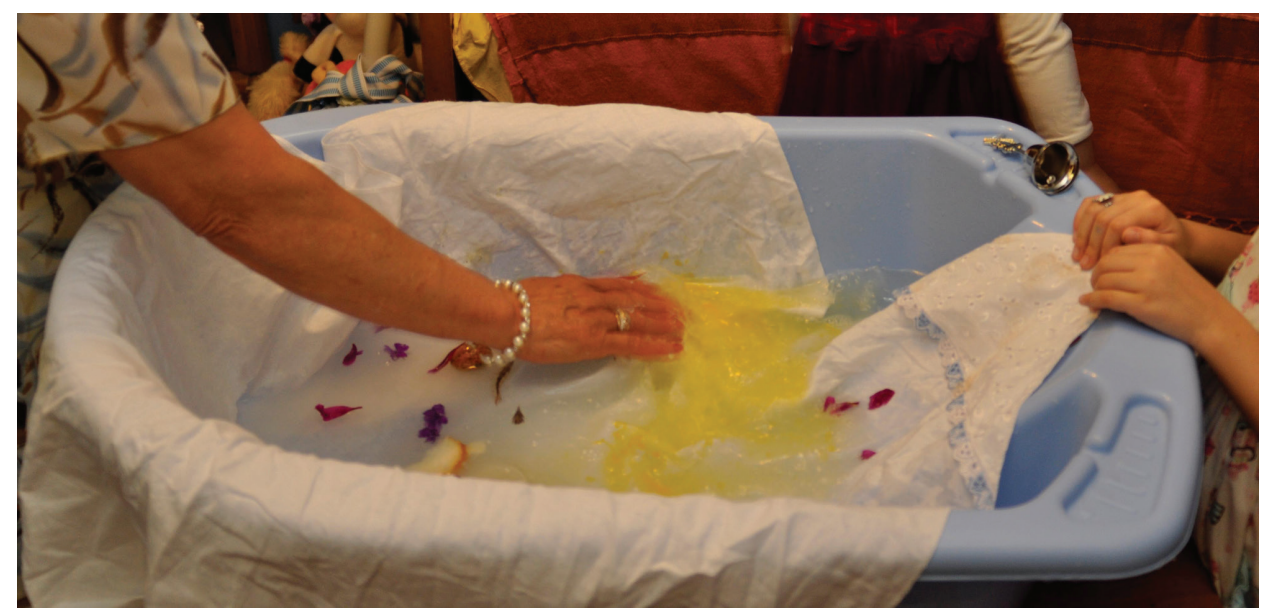

Figure 1. Preparation of a bath in Iaşi. The egg and petals are visible. A bell lies on the rim of the bathtub to positively influence the baby's voice. Photograph by Sergiu Ciubotariu 2013. 


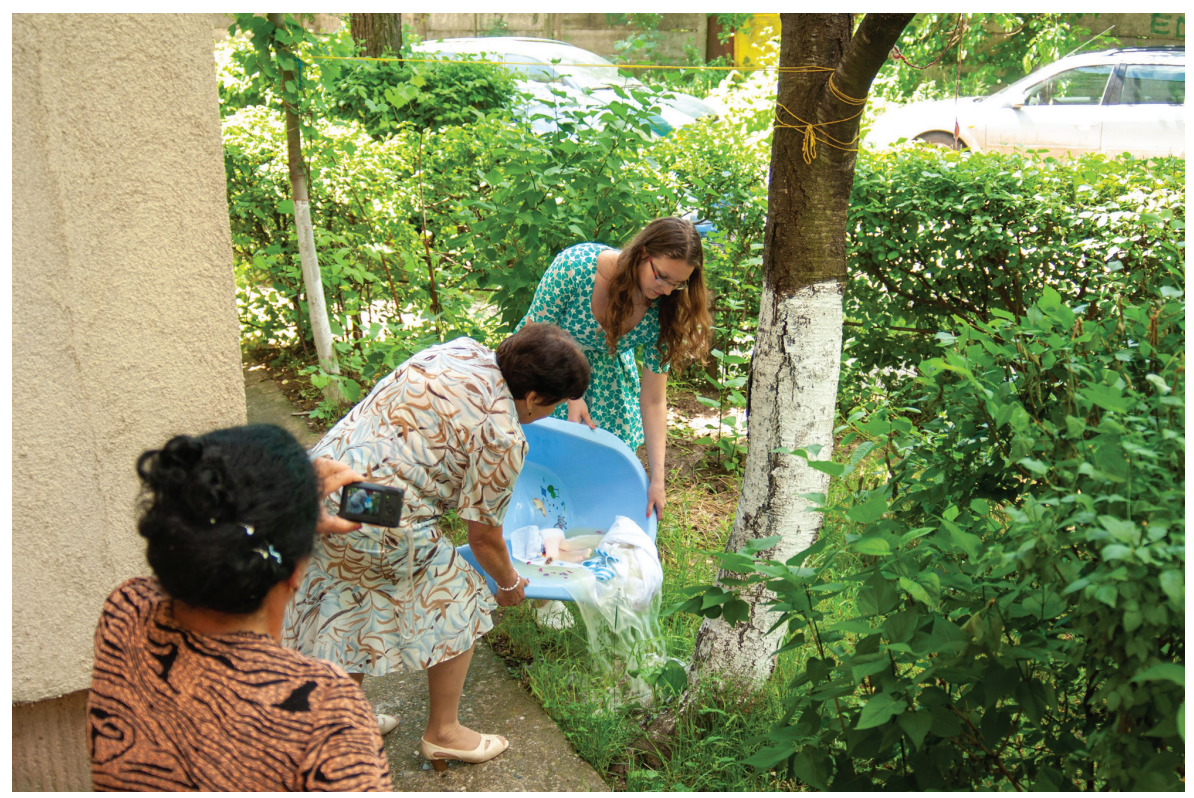

Figure 2. The ritual bathing water is poured at a tree in Iași. Photograph by Sergiu Ciubotariu 2013.

Figure 3. An olive tree planted near Rome, especially for the rite.

Photograph by Adina Hulubaș 2018.

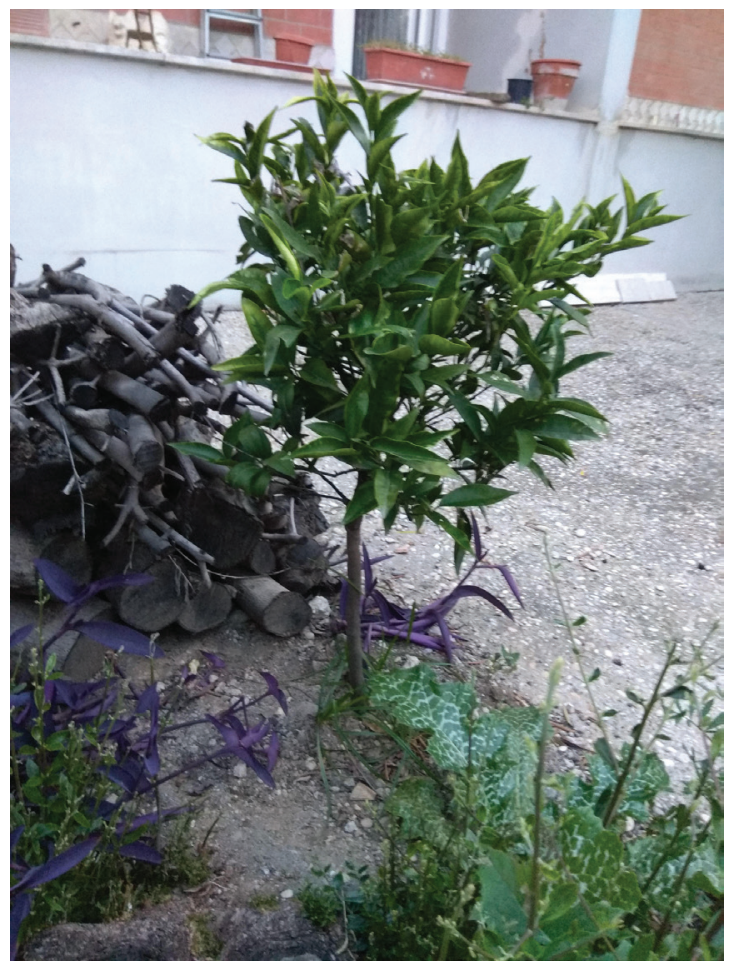


During the first bath and the one after baptism there were similar objects underneath the tub. The practice was maintained by L.N., who was living in Rome during the time of her child's scăldătoare (the washing performed by the godmother a day after christening). She placed a notebook, a pen, a comb, and a mirror under the bathtub, for her son to become smart, educated, and also handsome.

Holy water and drops of melted wax from the baptismal candle are further added in the bath. Hence, the water cannot be disposed of just as any other washing liquid. It has to be taken out and poured out at a tree while chanting and crying out (Fig. 2). The woman playing the role of a midwife leads the women's group regardless of the fact that they are in an urban area or even abroad. G.D. was in Rome when she had her guests carry the water down four storeys. A tangerine tree or an orange tree were too exotic for E.G. and M.N., considering the fact that they do not grow in the home country, Romania. Even more so, in the case of R.Z., the house owner bought him an olive tree especially for this occasion, and had it planted since there were no trees in front of the property (Fig. 3).

Urbanites also perform this ritual. M.D. declared that "you cannot throw the water down the drain, it is mandatory to pour it on a tall fruit tree, for the baby to grow tall and to bear fruit, to have offspring". E.B. believed that the child would be "beautiful like the tree", and G.M. added the feature of stateliness to the pleasant appearance. The practice was performed at childbirth, for the first bathing. The water used was taken to a tree, both by Romanians (Hulubaş 2012: 203) and Bulgarians: “the water from a baby's first bath was often emptied under a fruit tree, so that the child would 'grow as the tree grows"' (MacDermott 1998: 80).

A connection is thus established between the two, and the tree becomes an alter ego for the human being. However, the tree symbolism is ubiquitous during Romanian rites of passage, and the baby learns how to walk with the following words "Tree, little tree / Hold yourself like a tree" (in Tătăruşi village, Iaşi district). When the child grows up and gets married, a tree is decorated for the occasion. An alms tree is offered 40 days after death, since the deceased needs it in "the other world". Early in the morning of the first day of the New Year, children sing a ritual song called "Sorcova" and wish everybody to "grow old as an apple tree, as a pear tree". The verticality maintained even in heavy storms has transformed these tall plants into human ideals. All these beliefs are frequent among the Slavic people.

Among Luzatians in Polesie and in other Slavs' traditions, the custom to plant a fruit tree to mark the birth of a child is known, so that the child 
grows and develops like a tree. It was customary for all Slavs to pour the water in which they bathed the newborn under the fruit tree. Subsequently, the tree received the name of the child, and the Luzatians believed that it would grow like a tree, and the tree, in turn, would bring a rich harvest of fruit. In the case of a child's illness, they used this fruit tree for divinations about the child's fate: if the branches began to dry, they could die, and vice versa. Among the southern Slavs, it is a custom to bring the first cropped hair or nails of a child to a fruit tree, "so that the child develops like a fruit tree”. Among Bulgarians, fruit trees had a special role in the rituals of Babin Day, which is the traditional midwives' festival, many of whose magical acts were performed under the fruit tree. (Agapkina 1999: 71)

The energetic exchange between people and trees takes place in other circumstances as well. On the 1st of March people start wearing spring amulets called Mărţişoare and after 7 to 40 days they take them off and tie them to a blooming tree. Its condition during the year is an indicator of the well-being of the person who knotted the Mărţişor.

Contagious magic and analogies implied by these post-liminal rites confirm that "cultural acculturation comes after the material one, along with the process of integration to the urban setting" (Abraham 1991: 240). Therefore, traditional clothing, animal raising in the household and self-produced food are the first to disappear after migrating from the rural environment to internal urban settlements (international migration differs on the matter of traditional clothing, an increasing interest on ie - a hand-sewn shirt - being noticed in the past years), whereas rites and superstitions are performed continuously, for they also play a psychological role in the effort to cope with the new type of community. The future is not left to hazard and the family seems to be in control of outcomes. However, glimpses of the child's fate will be available just once more when they turn one and all their connections with the mysterious world they came from will be severed.

\section{THE FIRST TRIMMING AND FORETELLING OF THE CHILD'S OCCUPATION}

Up to the age of one, children are believed to be part of an unfamiliar universe. When adults are asked by the young where babies come from, they hide the process by answering in a mythological key. In the village of Ruginoasa, Neamt district, people still said in 1988 that newborns "are brought from the woods or taken from beneath the sun". Since children are not able to speak before the age 
of one, they seem to maintain a connection with this unknown origin. Moreover, the hair they grow during their first year of life belongs to the numinous place that created them. "To cut the hair is to separate oneself from the previous world" (Gennep 1960 [1909]: 166), and for the baby to fully come into the social environment the trimming must be performed by the godmother.

After this symbolic sacrifice that I will return to later, another glance at the future occupation is taken by the family, as if a secret door closes and one last peek is allowed. When the baby turns one, their godparents arrive at their house for the celebration, and a tray with various objects is presented to them. What they choose and take into their hand is to reveal the future job.

In the rural settlements investigated starting at the end of the 1960s, this rite was not found. The future occupation was mainly indicated by voluntary and involuntary acts. In the first category there was magic contagion provoked by the traditional birth attendant: specific tools appropriate for the sex of the baby were placed in his/her little hand right after the expulsion. For example, the newly born boy received a hammer, an axe, nails, a book and pencils or a whistle in his palm, whereas girls had a crochet and thread, a spindle or a needle in their little fists (Hulubaş 2012: 198). In 2011, a respondent from the village Hilița (Iaşi district) said that it is during the ritual bath after birth that the baby's future occupation reveals itself. Whatever objects float next to the baby's head indicate it. Later in the first year, when he/she starts toddling through the house, the first object coming to his/her hand speaks about what the child will do in life (Sălătruc, Bacău district).

The practice of actual choosing of an object has a long history in Asia. Documented as early as during the Song Dynasty (960-1279), Zhuazhou, which can be translated as "first birthday grab/pick", is celebrated when the baby is one year old. "The assortment of articles used to vary between boys and girls" (Zhao 2016 [2011]: 27) when they were subjected to this rite. In a manner similar to the old rural practice in Romania, Chinese boys used to receive a book, ink, money, and scissors (meaning they will become scholars, wealthy or tailors) for their pick, while girls had to choose from thread, a scoop, and a spoon (embroidery was suggested by the first, the other two items referred to cooking).

In Japan the practice is called Erabitori, meaning "choose and take an item". The selection of the objects is similar and so is the moment in the child's life. Boys would get a writing brush, ink, and an abacus, whereas girls find a book and a ruler in front of them (Ah Kim 2019: 97). Interestingly enough, in Armenia, Agra Hadig was initially purposed to find out the sex of the next baby (Rousseau 2017); the child around six months (the ritual is performed whenever their teeth erupt) had to choose between a knife (meaning that they would have a brother), or a comb/mirror (a sister was the next). The latter two 
items are still used by Vietnamese people, who celebrate Thôi Nôi ("to cease/ quit the cradle") when the baby turns one (Youmans 1887: 629). Money, a pencil, and a book are offered for their choice, all these also being present on the tray Romanians bring to their babies for the first birthday.

One more nation - the Koreans - celebrates the first year of life with this practice intended to look into the occupational future. Dol Janchi is "one of the most widely practiced birth customs today" (Kao 2012: 145). A pencil, a book, a ruler, money, thread, a needle, and scissors are given as ritual objects that foretell the occupation. Today, parents may keep using some items while rejecting others (Kao 2012: 146), a dynamic phenomenon that can also be observed at Romanians. Urbanites analyse the change in a rational manner; for example, M.D. says:

The parents place on the tray everything that comes to their mind, but they have bad ideas of putting the things that the child likes, that he/ she plays with frequently, together with new ones. Usually they put a little ball there, a toy car, car keys, maybe a syringe too, without thinking about what the baby will grab first. Of course the baby takes what he/she has never seen before!

The same judgement was made by M.T., who has been living in Rome, Italy, for the last fourteen years: "Everybody has an idea of what has to be presented to the child!" (Fig. 4)

While working with documents from the Folklore Archive of Moldavia and Bucovina I noticed that villagers in the second half of the twentieth century did not practice this forecasting rite; it was in urban settlements in the $2010 \mathrm{~s}$ that all parents made their children choose an item. However, Petru Caraman noted in 1956 that Aromanians (an ethnic group speaking a dialect of the Romanian language, mostly found south of the Danube River) used to present the one-year-old baby with a plate (tipsie) containing tools they selected carefully. The scholar argues that the rite is not a simple divination, but an attempt to influence the future by their own hierarchy of occupations (Caraman 2018 [2005]: 372). Only jobs agreed by parents are therefore available for selection, and the child's development is not left to chance.

Immigrants mentioned car keys, money, and gold rings as objects that might imply the child will be well-off, some paper, books, and pencils as symbols for an intellectual life, a lipstick and a comb as items suggesting an interest in beauty, and a fork or a spoon to see if the child will grow up to be a cook. C.T. declared that Romanian stores in Rome also sell kits for this occasion: a tray already set with various objects that might be decoded as job indicators. The first item picked up by the child is relevant from this point of view. 


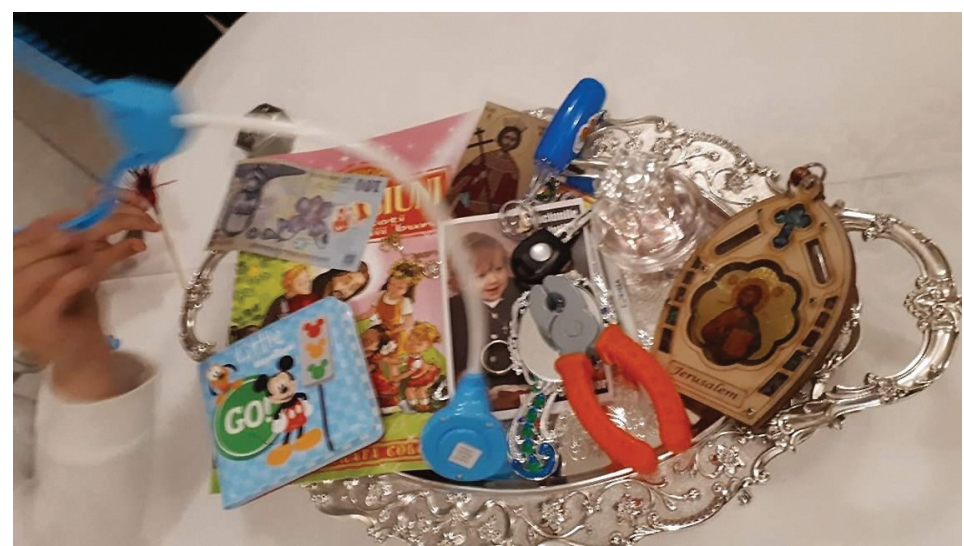

Figure 4. A tray with objects. Botoșani, Romania. Photograph by Alina Manolache 2019.

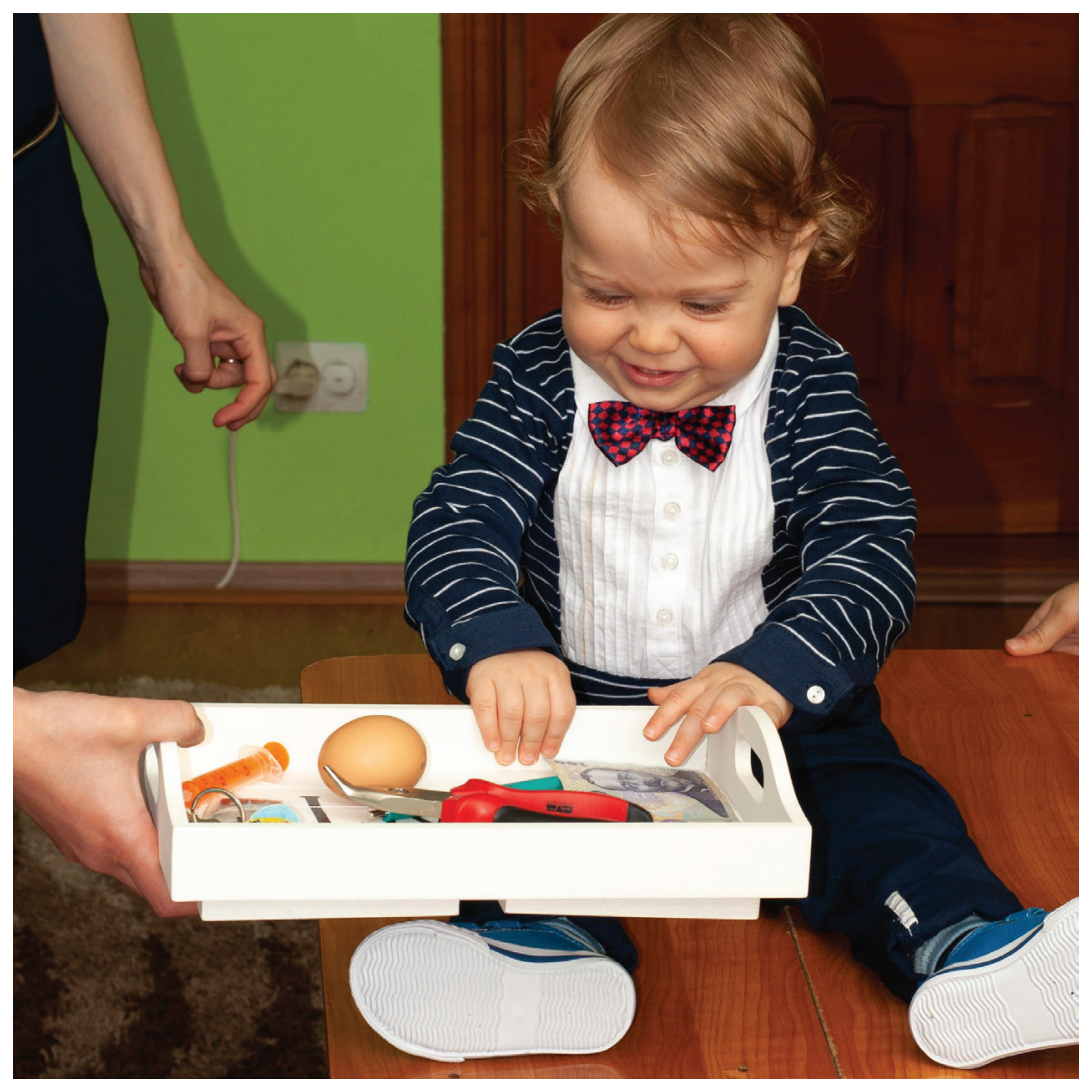

Figure 5. A boy is about to choose tongs from the tray. Iaşi, Romania. Photograph by Sergiu Ciubotariu 2014. 
Hence, many parents make the child choose three objects hoping that a better selection is thus obtained. Today smartphones, stethoscopes, or beads can be seen on the ceremonial tray, instead of hammers, tongs or scissors that were used in villages decades ago (Hulubaş 2014: 121). Among childbirth customs, this rite is most susceptible to modern influences, since it is directly linked to socio-economic development. There can no longer be a gender-based selection of items, but ideal occupations change in the collective mind. This rite of incorporation makes use of the last moments when the child stays in contact with the mysterious world they came from. This may explain their ability to recognize the tool that will define their life in the years to come (Fig. 5).

"The newborn comes from the invisible world, pertaining to the dead and to the night, in order to be integrated to the visible world, the one of the living and of the light" (Lepoutre 1997: 187). This image is familiar to the ritual songs that were sung at the baptism party (cumătrie) some time ago: "From a hole in the sedge / Here comes this Prince Charming / And he demands a hood and a necklace / To go to the white world" (Marian 1995: 158). The newborn enters the sparkling world of humans with the remanent energy. For this reason, the midwife and not anyone else has to carry them to church for christening; the godmother takes the baby in her arms only when the religious service starts. The hair that grew in the first year cannot be cut by anybody but her, since she is initiated and can handle numinous forces safely.

All the urbanites I talked to were familiar with the conviction that the godmother alone can cut the hair of the baby when he/she is one year old. C.T. lives in Rome and she told me she could hardly wait for the godparents to come and complete the ritual so that she could take the child to a hairdresser after that. In fact, the first time the child has his/her nails cut, it is the godmother who has to come and shorten them, otherwise the child will become a thief (Hulubaş 2012: 301). The same superstition was found among Italian immigrants from the United States of America (Malpezzi \& Clements 1998 [1992]: 65). For the first celebration, the godmother trims the baby's hair by cutting some tufts from four places on the head, suggesting the sign of a cross. She also cuts the nails and sticks the clippings on a coin with some melted wax from a candle. Sometimes it is the godfather who cuts the hair. In Gjakova, Kosovo, he performs this ritual on boys, while the godmother cuts the hair of girls (Kabakova 2000: 117).

This practice is also familiar to several other countries. Bulgaria and northern Ukraine are the closest countries to Romania where foretelling takes place in a similar manner (Sedakova 2009: 215). Here the baby lies on a sheepskin (kozhukh) and chooses from the items in front of him/her. This ritual element is significant during haircutting performed in the Lower Don region and on the western border with the Voronezh region in the Upper Don region: 
Of particular interest is the stable use of a kozhukh (a fur coat turned inside out), on which the child sat during haircutting, so that he/she would be rich. They laid out threads with needles, scissors, carpentry tools around the baby, or a book or cigarettes, bottles of alcohol, etc. From what the child reached out for, they learned what his/ her character, fate would be, what they would do. (Vlaskina 2009: 454)

The sheepskin is also used by Romanians when the child is brought home from the church, and on the second day, during the bathing that follows christening. In several districts in Moldavia, the godparents cover the child with this fur whether in the mother's arms or on a table (Hulubaş 2012: 246). The next day, the sheepskin is placed underneath the bathing tub, with the conviction that the child will prove lucky in raising these animals, hence he/she will be rich (Hulubaș 2012: 255).

Lise Bartoli (2007: 236) mentions African and Asian people for whom "it would be bad luck to keep the first hair that is considered to be still impregnated by its previous supernatural universe". In the south of India caudaka is performed "in preparation for the "second birth"' of the child (Hüsken 2009: 68), that is, the social coming into the world. Mundana is the eighth of the sixteen Hindu sacraments called Samskāras - rites of passage (Pelissero 2014: 63) or sacraments. During this rite all the hair is removed from the baby's head to free them from their past lives and from less fortunate features they might have kept. The Chinese call this event "good luck trim", while religious communities shear the hair to express a spiritual integration of the new member (Upsherin for Orthodox and Hasidic Jews).

The practice of removing the newborn's hair has a long documented existence, and this underlines the vitality of the belief that covers both space (as we saw it in many cultures) and time (Fig. 6). No later than 200 A.D., Tertullian acknowledged the first haircut to be a custom inherited by Christianity (1854: 611). The transmission was uninterrupted; we find it in the same disapproving discourse in the seventeenth century, when Bartolomeo Bassetti advocated its ceasing (Holban 1980: 54). The trimming has remained the same across ages and cultures, all elements connecting the child with the past existence or the unknown world they came from being annulled successively. The dried umbilical cord, the nail clippings, and the locks are taken from the baby with the conviction that a new life needs a fresh, undefiled beginning.

Once cut, the hair can be either kept in the house or thrown in a specific place. It is a widely-spread belief in Romanian villages that the tuft represents the child's good luck in life (Hulubaş 2012: 304), therefore it needs to stay inside the household, not to lose the well-being of the entire family. Rural respondents declared that they kept it at a house beam, on the Orthodox icon that is hung on the highest point of the eastern wall, beneath the mirror, or in a chest. In Slavic 
beliefs, it has to be "hidden in the house, as high as possible, to stimulate the growing of the child" (Kabakova 2000: 117).

C.T., who has been living in Rome, Italy, for the last sixteen years, also took care of the hair fixed on a coin and placed it in a pouch in a memory book "to be safe there". The unconscious cultural heritage demanded her not to just throw it away. Like her, most of the urbanites did not feel the need to explain themselves as to why they were keeping the lock in their homes. G.M. remembered that in his native village people used to put it in cow manure "for the child to grow as well as cattle do", a gesture that is also found in Ukraine (Sedakova 2009: 214). E.I. said that the hair should be disposed of in a herd in order to bring good luck (in raising them in the future). Contagious magic is used once more to attract positive events, to make them a part of the child's destiny. Nothing is left to hazard; the life course is charted when entering the community is at its beginning.

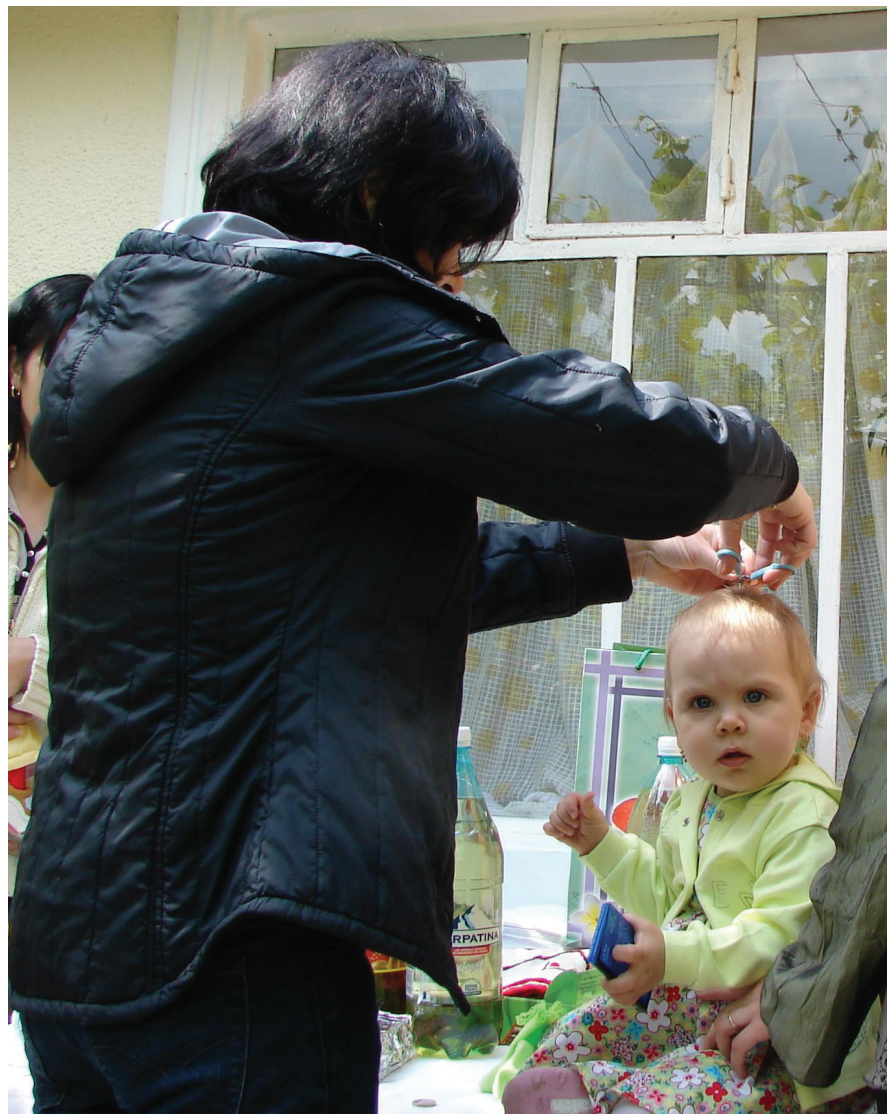

Figure 6. The godmother performs the symbolic first haircut in Tecuci, Romania. Photograph by Sergiu Chiubotariu 2008. 
Sometimes the hair becomes an offering to the surrounding nature. A tree reappears in the context of childbirth customs through the practice of putting the lock in it, so that the child's hair would grow as much as the tree (Hulubaş 2012: 304-305). In Motoșeni, in the district of Botoșani, Romania, people used to throw the first tuft cut from the head into a river, a practice that is also performed in eastern Slovakia and western Ukraine (Sedakova 2009: 214), and is similar to a Hindu ritual. Rishikesh is situated in the north of India and in this community boys are going through the Mundana ritual on the banks of the Ganges River (Agoramoorthy \& Hsu 2015: 1454). Their hair is washed away by the holy waters. People from central Thailand also worship rivers in this manner:

When the top-knot of a Siamese child has been cut with great ceremony, the short hairs are put into a little vessel made of plantain leaves and set adrift on the nearest river or canal. As they float away, all that was wrong or harmful in the child's disposition is believed to depart with them. (Frazer 1925 [1890]: 235)

The first haircut marks the end of taboos for the parent. The offspring now fully belongs to the social world and all wishful rituals are complete. The family is assured that the child's life will follow the path whose landmarks were set by rites. Displacement reinforces the inherited cultural behaviour, as we were able to see both for internal and international migration.

\section{CONCLUSIONS}

The article selected specific practices that on the one hand influence the becoming of the child, and on the other foretell their future. Rituals and superstitions that ward off the evil eye and other young-age afflictions are also well represented in Romanian childbirth practices, but they deal less with the future and more with the crucial moments of the early days, hence they are not discussed here. The fact that pregnant and parturient women as well as unbaptized children are highly receptive to the energies around them led to the appearance of two types of cultural reactions: apotropaic responses to the present possibly negative environment and gestures that augur well for the life to come. The latter intend to bring the generically called good luck (Rom. noroc) and I have analysed them in various ritual contexts.

Both preliminary and postliminary rites have an acknowledged psychological effect on mothers and their families. The attention on things that mould or tell the future also manages to ease the worries on the fate of the newborn. The pregnancy phase is tensed due to mothers being highly aware of the power of 
looking and being overlooked. Such superstitions have survived well in urban settlements and women try to take benefits from pleasant sightings. After birth the child is protected from the evil eye by a strategy that consists in a chromatic distraction.

Postliminary rites discussed above are centred on the figures of the godparents who have to be socially respectable. They will mould the future of the newborn in successive ways: by christening, during the second-day bath, by cutting their nails and hair, and by making the selection of objects to be chosen during the foretelling of the child's occupation. Obvious similarities with countries neighbouring Romania are joined by strikingly resembling practices and convictions from Tanzania, Armenia, China, India, Korea, Vietnam, Thailand, and Japan. Hence, the image of childbirth perception in the world is more complete, revealing common preoccupations and even social processes in coping with a new member of the family.

Examples from fairy tales and Christmas carols stress the magic imagery that I found in the active birth practices in Romania and abroad. Internal and international migration does not reduce the performing of traditional rites for the first generation; on the contrary, they enhance the need to participate in such identity-marked moments. Childbirth practices bear the most divinatory acts amongst the rites of passage and their continuation to the present day is remarkable. Despite the slight shift to aesthetic, entertaining purposes, each phase of these practices is performed in full conviction that the story of the new child will unfold as forecasted.

\section{ACKNOWLEDGEMENTS}

This work was supported by a grant of the Romanian Ministry of Research and Innovation, CCCDI - UEFISCDI, project number PN-III-P1-1.2PCCDI-2017-0116, within PNCDI III. Special thanks to Nina Vlaskina, who translated several Russian references and kindly made them available to me.

\section{NOTE}

1 The interviews were carried out within the series of projects "MIRO: Migration and identity in the Romanian cultural milieu. Research design, methodology, and expectations", supported by a grant of the Romanian Ministry of Research and Innovation, CCCDI - UEFISCDI, project number PN-III-Pl-1.2-PCCDI-2017-0116 I 48PCCDI/2018", within PNCDI III. 


\section{REFERENCES}

Abraham, Dorel 1991. Introducere în sociologia urbană. [Introduction to Urban Sociology.] Bucharest: Editura Ştiinţifică.

Agapkina, Tatiana 1999. Derevo plodovoe. [Fruit Tree.] In: Nikita Tolstoi (ed.) Slavianskie dreunosti:etnolingvisticheskii slovar'. Vol. 2. Moscow: Mezhdunarodnye otnosheniia, pp. 70-73. Available at https://vk.com/wall-112143772_8486, last accessed on 5 October 2020.

Agoramoorthy, Govindasamy \& Hsu, Minna J. 2015. Living on the Societal Edge: India's Transgender Realities. Journal of Religion and Health, Vol. 54, No. 4, pp. 14511459. http://dx.doi.org/10.1007/s10943-014-9987-z.

Ah Kim, Jeong 2019. A Study of Traditional Baby Rituals and Costumes of Japan. Journal of the Korean Society of Costume, Vol. 69, No. 7, pp. 91-108. https://doi.org/10.7233/ jksc.2019.69.7.091.

Bartoli, Lise 2007. Venir au monde. Les rites de l'enfantement sur les cinq continents. Paris: Édition Payot \& Rivages.

Brătulescu, Monica (ed.) 1964. La luncile soarelui. Antologie a colindelor laice. [On the Fields of the Sun. Laic Carols Anthology.] Bucharest: Editura Pentru Literatură.

Callister, Lynn Clark 1998. Giving Birth: Guatemalan Women's Voices. Journal of Obstetric, Gynecologic, and Neonatal Nursing, Vol. 27, No. 3, pp. 289-295. https:// doi.org/10.1111/j.1552-6909.1998.tb02651.x.

Caraman, Petru 2018 [2005]. Restituiri etnologice. [Ethnological Restitutions.] Edited, introduction and notes by Ion H. Ciubotaru. Iaşi: Editura Universităţii “Alexandru Ioan Cuza".

Ciubotaru, Ion H. 2012. Ouăle de Paşti la români. Vechime, semnificaţii, implicații ritual-ceremonial. [Easter Eggs at Romanians. Age, Meanings, Ritual-ceremonial Implications.] Iaşi: Editura Presa Bună.

Creţu, Vasile Tudor 2014. Ethosul folcloric - sistem deschis. Existenţa ca întemeiere. [The Folkloric Ethos - an Open System. Existence as a Foundation.] Timişoara: Editura Universităţii de Vest.

Frazer, James George 1925 [1890]. The Golden Bough: A Study in Magic and Religion. Abridged edition. New York: The Macmillan Company. Available at https://archive. org/details/cu31924021569128, last accessed on 5 October 2020.

Geertz, Clifford 1957. Ritual and Social Change: A Javanese Example. American Anthropologist, Vol. 59, No. 1, pp. 32-54. https://doi.org/10.1525/aa.1957.59.1.02a00040.

Gélis, Jacques 1991. History of Childbirth: Fertility, Pregnancy, and Birth in Early Modern Europe. Boston: Northeastern University Press.

Gennep, Arnold van 1960 [1909]. The Rites of Passage. Transl. by Monika B. Vizedom \& Gabrielle L. Caffee. Introduction by Solon T. Kimball. Chicago: University of Chicago Press.

Golovakha-Hicks, Inna 2008. The Life of Traditional Demonological Legends in Contemporary Urban Ukrainian Communities. Folklore: Electronic Journal of Folklore, Vol. 40, pp. 37-44. http://dx.doi.org/10.7592/FEJF2008.40.golovakha.

Holban, Maria (ed.) 1980. Călători străini despre Ţările Române. [Foreign Travellers about Romanian Lands.] Vol. VII. Bucharest: Editura Ştiinţifică şi Enciclopedică. Available at https://ru.calameo.com/read/0008274337a09cc1eb04b, last accessed on 5 October 2020. 
Hulubaş, Adina 2012. Obiceiuri de naştere din Moldova. Tipologie şi corpus de texte. [Childbirth Customs from Moldavia. A Typology and Texts Corpus.] Iaşi: Editura Universităţii "Alexandru Ioan Cuza". Available at https://www.academia. edu/9703923/Obiceiuri_de_nastere_din_Moldova._Tipologie_si_corpus_de_texte, last accessed on 5 October 2020.

Hulubaş, Adina 2014. Credinţe despre naştere în contextual urban din Moldova: Memoria tradiţională. [Childbirth Beliefs in the Urban Context in Moldavia: The Traditional Memory.] Iaşi: Editura Universităţii “Alexandru Ioan Cuza”. Available at https:// www.academia.edu/9703941/Credinte_despre_nastere_in_contextul_urban_din Moldova._Memoria_traditionala, last accessed on 5 October 2020.

Hüsken, Ute 2009. Vișinu's Children. Prenatal Life-cycle Rituals in South India. Wiesbaden: Harrassowitz Verlag.

Jordan, Brigitte \& Davis-Floyd, Robbie 1993 [1978]. Birth in Four Cultures: A Crosscultural Investigation of Childbirth in Yucatan, Holland, Sweden, and the United States. 4th ed. Prospect Heights: Waveland Press.

Kabakova, Galina 2000. Anthropologie du Corps Féminin dans le Monde Slave. Paris: L'Harmattan.

Kao, Grace Y. 2012. Exploring the Korean First Birthday Celebration (Dol Janchi) as a Site for Comparative Religious Ethics and Asian American Christian Ethics. In: Elizabeth M. Bucar \& Aaron Stalnaker (eds.) Religious Ethics in a Time of Globalism. New York: Palgrave Macmillan, pp. 145-176. https://doi. org/10.1057/9781137273031_7.

Laderman, Carol 1984. Food Ideology and Eating Behavior: Contributions from Malay Studies. Social Science \& Medicine, Vol. 19, No. 5, pp. 547-559. https://doi. org/10.1016/0277-9536(84)90050-9.

Lepoutre, Marie 1997. D’une médecine à l'autre. Grossesse et enfantement: ethno-histoire du pluralisme medical à Lifou Nouvelle-Caledonie, Thése de Doctorat. EHESS.

Liamputtong, Pranee 2009. Pregnancy, Childbirth and Traditional Beliefs and Practices in Chiang Mai, Northern Thailand. In: Helaine Selin (ed.) Science across Cultures: The History of Non-Western Science. Vol. 5. Childbirth Across Cultures, Science Across Cultures: Ideas and Practices of Pregnancy, Childbirth and the Postpartum. Dordrecht: Springer, pp. 175-184. https://doi.org/10.1007/978-90-481-2599-9_15.

Mabilia, Mara 2007 [2005]. Breast Feeding and Sexuality. Behaviour, Beliefs and Taboos among the Gogo Mothers in Tanzania. Transl. by Mary S. Ash. New York \& Oxford: Berghahn Books.

MacDermott, Mercia 1998. Bulgarian Folk Customs. London \& Philadelphia: Jessica Kingsley Publishers Ltd.

Malpezzi, Frances M. \& Clements, William M. 1998 [1992]. Italian-American Folklore. Little Rock: August House Inc.

Marian, Simeon Florea 1995. Naşterea la români: Studiu etnografic. [Childbirth at Romanians: An Ethnographic Study.] Bucharest: Editura Grai şi Suflet - Cultura Naţională.

Mathole, Thubelihle \& Shamu, Simukai 2009. Childbirth in Zimbabwe. In: Helaine Selin (ed.) Science across Cultures: The History of Non-Western Science, Vol. 5. Childbirth Across Cultures, Science Across Cultures: Ideas and Practices of Pregnancy, Childbirth and the Postpartum. Dordrecht: Springer, pp. 205-213. https://doi. org/10.1007/978-90-481-2599-9_18. 
Mongeau, Beatrice \& Smith, Harvey L. \& Maney, Ann C. 1961. The "Granny" Midwife: Changing Roles and Functions of a Folk Practitioner. American Journal of Sociology, Vol. 66, No. 5, pp. 497-505. https://doi.org/10.1086/222972.

Pelissero, Alberto 2014. Introducere în Hinduism. [Introduction to Hinduism.] Iaşi: Editura Polirom.

Pop, Mihai \& Ruxăndoiu, Pavel 1978 [1976]. Folclor literar românesc. [Romanian Literary Folklore.] Bucharest: Editura Didactică şi Pedagogică.

Redfield, Robert 1947. The Folk Society. American Journal of Sociology, Vol. 52, No. 4, pp. 293-308. https://doi.org/10.1086/220015.

Rousseau, Bryant 2017. In Armenia, 'What Do You Want to Be?' Is Asked in Infancy. The New York Times, 12 March. Available at https://www.nytimes.com/2017/03/12/ world/europe/armenia-atam-hatik-agra-hadig.html, last accessed on 5 October 2020.

Sedakova, Irina 2009. Postrizhiny. [Haircutting.] In: Nikita Tolstoi (ed.) Slavianskie dreunosti: etnolingvisticheskii slovar'. Vol. 4. Moscow: Mezhdunarodnye otnosheniia, pp. 212-215.

Teodorescu, G. Dem (ed.) 1996. Basme române. [Romanian Fairy-tales.] Bucharest: Editura Vitruviu.

Tolstaia, Svetlana 2009. Pravyi - levyi. [Right - Left.] In: Nikita Tolstoi (ed.) Slavianskie drevnosti: etnolinguisticheskii slovar'. Vol. 4. Moscow: Mezhdunarodnye otnosheniia, pp. 233-237.

Tertullian, Quinti Septimii Florentis 1854. Quae Supersunt Omnia. Vol. II. Edited by Franciscus Oehler. Leipzig: T. O. Weigel.

Văduva, Ofelia 1997. Magia darului. [The Magic of the Gift.] Bucharest: Editura Enciclopedică. Vlaskina, Tatiana 2009. Pervaia godovshchina rozhdeniia rebenka v traditsiiakh donskikh kazakov. [First Anniversary of a Child's Birth in Don Cossacks'Traditions.] Problemy istorii, filologii, kultury / Journal of Historical, Philological and Cultural Studies, Vol. 23, No. 1, pp. 446-456. Available at https://cyberleninka.ru/article/n/pervayagodovschina-rozhdeniya-rebenka-v-traditsiyah-donskih-kazakov, last accessed on 5 October 2020.

Werner, Heinz 1980 [1926]. Comparative Psychology of Mental Development. New York: International Universities Press.

Youmans, William J. (ed.) 1887. Ethnological Sketches in Annam and Tonquin. The Popular Science Monthly, Vol. 31, pp. 626-635. Available at https://en.wikisource.org/wiki/ Popular_Science_Monthly/Volume_31/September_1887/Ethnological_Sketches_in_ Annam_and_Tonquin, last accessed on 5 October 2020.

Zhao, Lucy 2016 [2011]. Rituals and the Life Cycle. In: Xiaowei Zang (ed.) Understanding Chinese Society. 2nd ed. London \& New York: Routledge, pp. 25-35. Available at https://sgp1.digitaloceanspaces.com/proletarian-library/My-library/Xiaowei\%20 Zang/Understanding\%20Chinese\%20Society\%20(434)/Understanding\%20 Chinese\%20Society\%20-\%20Xiaowei\%20Zang.pdf, last accessed on 5 October 2020.

Adina Hulubaş is Senior Research Fellow working at the Iaşi Branch of the Romanian Academy. She took her doctoral degree on initiatory rites in Romanian literary folklore in 2009. Her main research areas are childbirth customs, vernacular architecture, traditional occupations, folklore didactics, and intangible cultural heritage. She has been a member of UNESCO Global Network of Facilitators since 2017.

adina.hulubas@gmail.com 


\title{
"COMING INTO THE WORLD: FROM SPIRITS TO THE SPIRIT". THE FIRST CHILDHOOD MUSEUM IN ROMANIA
}

\author{
Anamaria Iuga \\ PhD, Head of the Ethnology Studies Department \\ National Museum of the Romanian Peasant \\ Fellow 2019-2020 New Europe College \\ Institute for Advanced Study, Romania \\ anaiuga@gmail.com
}

\begin{abstract}
The present paper follows the National Museum of the Romanian Peasant (Romania) in its endeavour to display the Virtual Museum of Childhood. The context prior to exhibiting material and intangible heritage related to childhood is analysed, and the curatorial challenges of this project are mentioned. This article also refers to the museum's activities dedicated to childbirth (exhibitions, cultural activities), from 1990 to the present day, but it especially focuses on the first exhibition of the Museum of Childhood, "Coming into the world: From spirits to the Spirit", dedicated to birth.
\end{abstract}

Keywords: childbirth, exhibition, intangible heritage, Museum of Childhood, Museum of the Romanian Peasant

\section{INTRODUCTION}

As Horia Bernea, ${ }^{1}$ the creator of the Museum of the Romanian Peasant (Bucharest, Romania), ${ }^{2}$ stated, this institution is "a museum of context, of relation (between objects and space), of rhythm" (Bernea 2001: 71), an unconventional museum, defined by "a perpetually prolific state continuously allowing for new beginnings" (ibid.: 82). This is a perfect definition for a museum which was reborn in 1990, in a building meant to be a village art museum but repurposed by the communist regime to be an ideological museum (Popovăț 1999). The Museum of the Romanian Peasant exhibits and speaks about the traditional world, which "did not 'produce' objects, but begot" (Bernea 2001: 123) - to sum up, a museum where "genesis" can be found at different levels, from the appearance of a new institution to exhibiting intangible heritage related to childbirth, and to creating a new museum dedicated to childhood, as shown below. 
To start from the very beginning, I should first mention that the researchers of the Museum of the Romanian Peasant have always shown a distinct interest in the activities involving children or in events related to childhood, Ioana Popescu, ${ }^{3}$ ethnologist and part of Horia Bernea's founding team, being the consistent promoter of this curatorial focus. Ioana Popescu and Irina Nicolau ${ }^{4}$ were a good team in this research area even since they were both working at the Institute of Folklore (Romanian Academy) (Popescu \& Nicolau 1983). Their interest in studying the cultural heritage referring to childhood and especially to childbirth was so strong that Irina Nicolau once said: "If we are to be experts in something, I'd rather be one in childbirth" (I.P. ${ }^{5}$. Anyhow, it was definitely Ioana Popescu's keenness for childhood that started this research interest: "for years she [Ioana] was haunted by a museological approach to children" (Irina Nicolau in Bernea 2001: 34). However, the two researchers intended to open a "Copilarium" (Childarium) (I.P.), a space dedicated to children - an idea which led to an original cultural project and to opening the Virtual Museum of Childhood ${ }^{6}$ in 2013.

The present paper intends to explore the history of cultural and research approaches related to childhood and childbirth, carried out by the museum. The resources I have used range from published materials (Bernea 2001; Popescu et al. 1991; Martor 2013) to my own experience within the European project Childhood: Remains and Heritage. ${ }^{7}$ Yet, the most important source of information is given by Ioana Popescu, interviewed on 17 February 2020. The ethnologist speaks about the activities carried out at the museum from its very beginning, activities related to events or exhibitions for or about children or childhood. The interview proves a constant interest in this topic as well as the challenges they faced.

\section{MUSEUM, CHILDHOOD, AND BIRTH}

When the museum was initiated, by chance or by hazard, or I don't know how, the first small team of the museum, from the first day of the museum, was mainly made up of women. Most of them women around 30 years of age. So, they were somehow on their way up in their career, at the same time having children, young children ... it felt as if you were stepping on a minefield, as you were not good enough at either museum work or parenting, everything was new. And then, somehow, the solution was to combine parenting with museum development. (I.P.)

These memories were revisited at the very beginning of the interview, emphasising the tight connection between the opening of the museum and children- 
related activities. Moreover, as Ioana remembers, in 1990-1991, children were regularly present in daily activities: "Children's touch was in almost everything we were doing, this was how things were working" (I.P.).

The beginning of the museum is defined by activities dedicated to children. For instance, as the museum was not yet open at the beginning of the year 1990, and in order to attract the attention of the public, the director Horia Bernea decided to open it up to the public with an exhibition hosted by Galeriile Orizont ${ }^{8}$ in the heart of Bucharest. The first one was dedicated to clay toys, "having as the main character a mother holding a baby" (I.P.). It is an important detail considering that the museum was first opening up to the public exhibiting objects dedicated to children. The first creativity workshops (see Oprea-Minoiu et al. 2017) were also organised at that time, as there was a special room for children's creative activities. As a novel and playful detail, the room featured a poster at the entrance "which read, to parents' dismay, 'Access of parents unattended by children strictly forbidden" (I.P.). ${ }^{9}$

While the first public exhibition was dedicated to children, the first temporary exhibition opened in the museum building in $1991,{ }^{10}$ the second year of its existence, and was dedicated to childbirth, another significant gesture in emphasising the interest in the topic of childhood (Fig. 1). The exhibition titled Prunc (Infant) was a novel one, "uncommon even for the ethnographic museology of today, because there were a number of beliefs [exposed] in it. It was a trial, a successful one I would say, to exhibit intangible culture" (I.P.). Irina Nicolau explained:

[It was about] exhibiting a hypothesis hard to digest and even harder to communicate: in its first weeks, maternity is a terrible experience. The child, coming from who knows where, disputed by both people and evil ghosts... We wanted to talk about the horror of childbirth, about a mother's fears and her care for the baby. (Bernea 2001: 37)

The exhibition mostly highlighted the intangible heritage "using tiny signs, tiny handwriting, a detail on the floor, things like these, impactful things, which made you understand a certain belief" (I.P.). The beliefs presented in this exhibition (see Fig. 2 to perceive the way they were exhibited) covered various topics: interdictions during pregnancy, childbirth, signs about the future of the child, baby's first bath, choosing the child's name, practices referring to healing childhood diseases, etc. As Irina Nicolau recalled, one of Horia Bernea's requests referred to including the ritual of baptism, meant to bring peace in the unstable postnatal period: "He came and said: how do you think there can be so much darkness without the deliverance of baptism? And right away he started to paint the 'iconostasis' for the birth in Spirit” (Irina Nicolau in Bernea 2001: 38). 


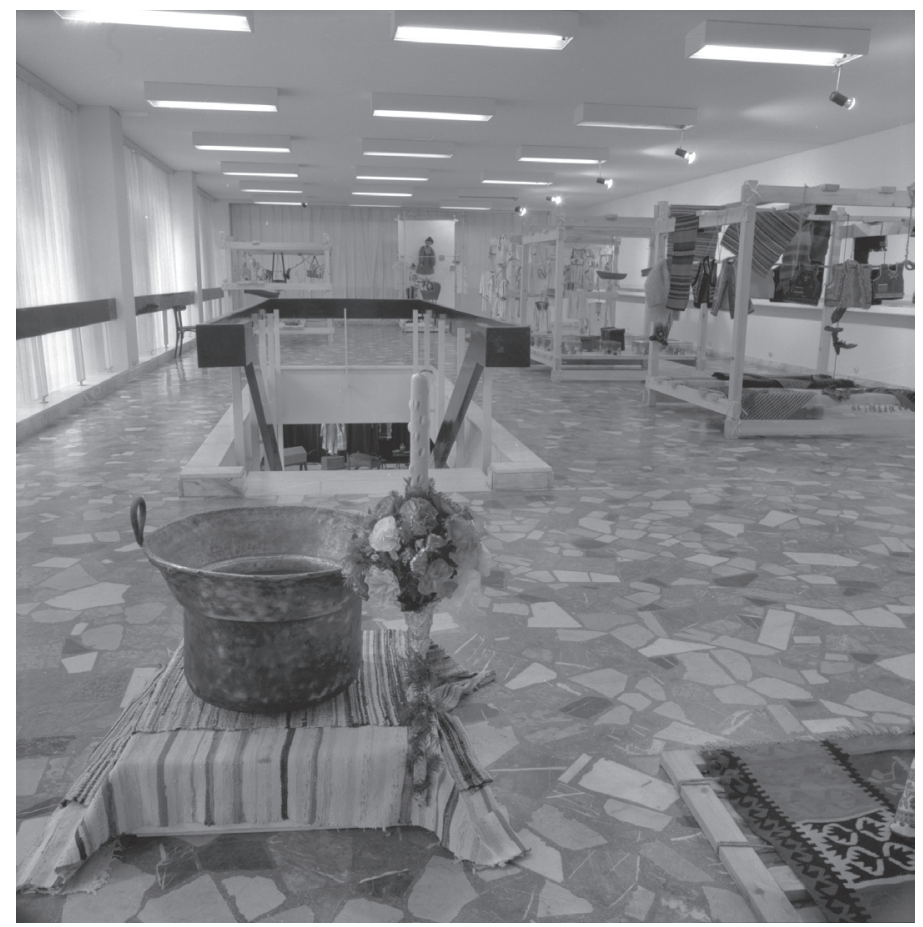

Figure 1. Overview of the exhibition Prunc (Infant), 1991. Photograph by Marius Caraman, in possession of the Ethnological Archive of the National Museum of the Romanian Peasant.

Birthing beliefs were also covered by the catalogue titled Prunc (Popescu et al. 1991), published in "200 numbered copies on white paper in brown ink" (ibid.: ii). The publication was illustrated with children's drawings inspired by icons painted on glass, especially those dedicated to the Nativity of Jesus.

Referring to material culture, "the exhibition displayed only few valuable objects, to put it this way ... The exhibition was conceived as a route running between shown and hidden, somehow you saw some things partially, and you had to guess some things behind some panels, things that you could not see, because, I repeat, we were playing with the immaterial ... Regarding the objects displayed, if I remember well, there were 2-3 clay toys, some thick rural swaddling clothes which had nothing to do with our perception of urban babies, wearing white and lacy outfits ... meant to shock somehow, to show that things could be totally different." (I.P.)

Anyway, from the very entrance visitors were overwhelmed by "dark" beliefs regarding giving birth. The first thing visible when entering the exhibition was "a large piece of paper, in ugly and striking writing, ugly indeed, conspicuously 


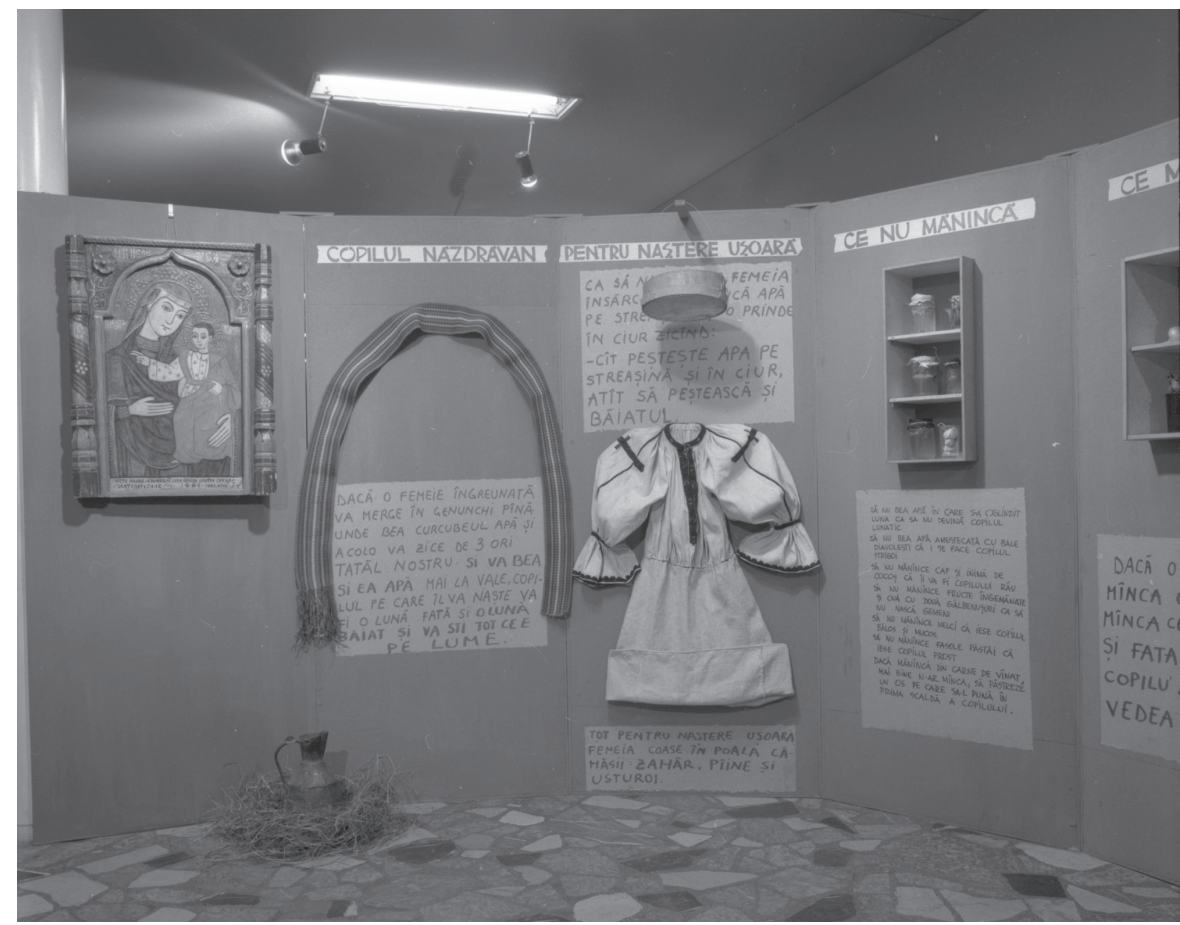

Figure 2. Detail from the exhibition Prunc (Infant), 1991. Photograph by Marius Caraman, in possession of the Ethnological Archive of the National Museum of the Romanian Peasant. Texts from the image, from left to right: "FOR A SPECIAL CHILD. If a pregnant woman would go on her knees to the place the rainbow starts and would say three times Holy Father and drink water, the child she delivers will be one month a girl, and one month a boy, and will know all there is to know in this world." "FOR AN EASY BIRTH. To have an easy birth, the pregnant woman should catch the water that falls from the rims of the house and the sieve, and say: As the water does not remain on the rims of the house and in the sieve, the same will happen to the baby to be born. Also, for an easy birth, the women would sew into the lap of the shirt sugar, bread, and garlic." WHAT PREGNANT WOMEN DO NOT EAT [fragments]. She should not drink water that mirrored the moon, for the child not to be lunatic. She should not eat the head and the heart of a rooster, because the baby will be evil. She should not eat twinned fruits, or eggs with two yolks, or she would have twins. Etc."

ugly, which read: 'A woman without children is running around wildly and knows nothing about God"' (I.P.). Thus, the audience was sifted: if the visitor was a woman who did not have children, after reading this first text she "turned around and left" (I.P.).

Once this warning was walked past, the exhibition opened "with a narrow red area which made you think about the womb" (Irina Nicolau in Bernea 2001: 37). The "abortion corner" was among the first things that could be seen. It was a "shabby rag stained with red paint, meaning blood ... So, it was something 
dirty, dreadful, which was in your way, and could not be avoided" (I.P.). Here are Irina Nicolau's memories:

I can't remember who had the idea of throwing somewhere next to a wall a rag stained with ink 'blood'. At the opening, our friends were trying to hide the rag, kicking it around. The second day we glued it to the floor. Enough! During labour you cannot ignore completely the blood, lochia, the placenta, the navel. This is how people are born, producing some residues, and peasants were in the know about them. (Bernea 2001: 37)

The public had contradictory reactions because "the exhibition was so freshly authentic, so honest that it bothered many people" (I.P.). Undoubtedly, this first exhibition dedicated to childbirth echoed further on, being one of the main sources of inspiration for the exhibition opening the Museum of Childhood years later.

Yet, apart from other events dedicated to children and childhood, ${ }^{11}$ there are two more types of activities worth mentioning, chronologically speaking, in relation to the theme of giving birth. As Ioana recalls:

The next step in the relationship with [the topic of] childbirth, at least in my case, was a surprising request. Médecins Sans Frontières urgently requested a specialist from the Museum of the Peasant to deliver two lectures ... on birth beliefs and practices in Romania. (I.P.)

The talks were given by Ioana and, as she remembers, "[the doctors] were listening carefully, were writing down, interrupting me and asking questions about a lot of details that I wasn't aware of. Details related to gestures, to sequencing: if they spit before or during uttering the charm, things like this. And they would exclaim: Ah! That's why they didn't allow us to do that!" (I.P.)

This experience speaks not only about cultural differences but also about the practical role of ethnology.

Later on, in the 1990s, the programme called "Missionary Museum" was launched. It entailed that the specialists were to go to "places less visited by the museum and to leave something behind: a small exhibition, or a talk, a performance, a gesture, something" (I.P.). Most of the time they would leave behind the brochure titled Kind thoughts with texts of "Romanian and Orthodox wisdom mainly dedicated to maternity. [Irina] would have liked to place a brochure on each bedside cabinet in a maternity ward." (I.P.)

Therefore, the beginning of the museum is linked to the interest in children, and especially to the interest in the traditional culture of giving birth. Thus, the museum is also born out of the endeavour of the researchers who 
are "specialists in childbirth" (I.P.), generating an important direction which, among other things, led to the opening of the Virtual Museum of Childhood.

\section{THE BIRTH OF THE MUSEUM OF CHILDHOOD}

The Museum of Childhood was the natural corollary of the constant interest in this direction. As a result of an EU-funded cultural project, in partnership with other European institutions, this museum was meant to fill a lack in the Romanian cultural landscape, namely the absence of a museum dedicated to childhood, which "will cover this period entirely - meaning childhood in everyday life, childhood with celebrations, childhood with diseases, health, everything you can think of, childhood with children's oral productions, childhood with community's products dedicated to children" (I.P.). Therefore, in 2013, the Museum of Childhood was inaugurated online, as there was no physical space to host such a museum. After a year of research and documentation, a series of six temporary exhibitions were opened. Before closing, each exhibition was photographed, using the technique of panning and turned into a virtual museum room. There are six such exhibition spaces, ${ }^{12}$ one dedicated to creativity workshops organised within the cultural project (Room 7), and another one hosting a travelling exhibition (Room 8) (see also Passima 2013), organised as a summary of the six temporary exhibitions and opened in seven European cities. ${ }^{13} \mathrm{~A}$ unique aspect of this project is that it brought up a larger cultural dialogue, extended over the European cultural area, not restricted to the Romanian one. Therefore, in each exhibition there was "a slight detail, a tiny highlight, a detail of western culture; to find out whether things are similar, how similar or different they are" (I.P.).

Displaying intangible heritage was again one of the challenges; yet, unlike 1991, there was a new technology to be used this time. Consequently, together with objects, images, and written texts, audio materials were also displayed: spoken fragments, stories, part of interviews and lullabies, but also videos present in both physical and virtual exhibitions. Regarding childhood's material culture, the objects from the museum's collections were brought from home by the people involved in this project:

Some of the objects had been collected by volunteers, we brought some things, and others were bought for this very exhibition, because it needed to have elements from other cultural European areas, especially past and present-day ones. ... And, in order to show these things, we went shopping at IKEA, and all sorts of pan-European shops. (I.P.) 


\section{"FROM SPIRITS TO THE SPIRIT": ABOUT BIRTH AT THE MUSEUM OF CHILDHOOD}

As expected, the first exhibition that opened at the Museum of Childhood was dedicated to childbirth.

[It is] a discourse about gestation: the future child appears from nowhere into the mother's womb, ... then his / her organic growth inside the mother's body, the bloody, hurtful and tormented exit; how all these disrupt the quiet, peaceful, serene village. And the village perceives this time as haunted. ... So, everybody focuses on attracting the good forces and on protecting against the evil ones. These are the spirits. And therefore, I said ... from the spirits to the Spirit, as after birth, soon after birth ... baptism is performed. And baptism calms down everything. (I.P.)

The exhibition mainly displayed objects: some traditional, found in the museum's collection, but also modern, contemporary ones (Fig. 3). Many photographs were also shown: from the archives of our partner institutions, but also from our volunteers' personal archives. Moreover, fragments of the intangible heritage (handwritten texts about old rural beliefs, and also about new contemporary Romanian or European beliefs or practices hung or glued to the wall) were also present.

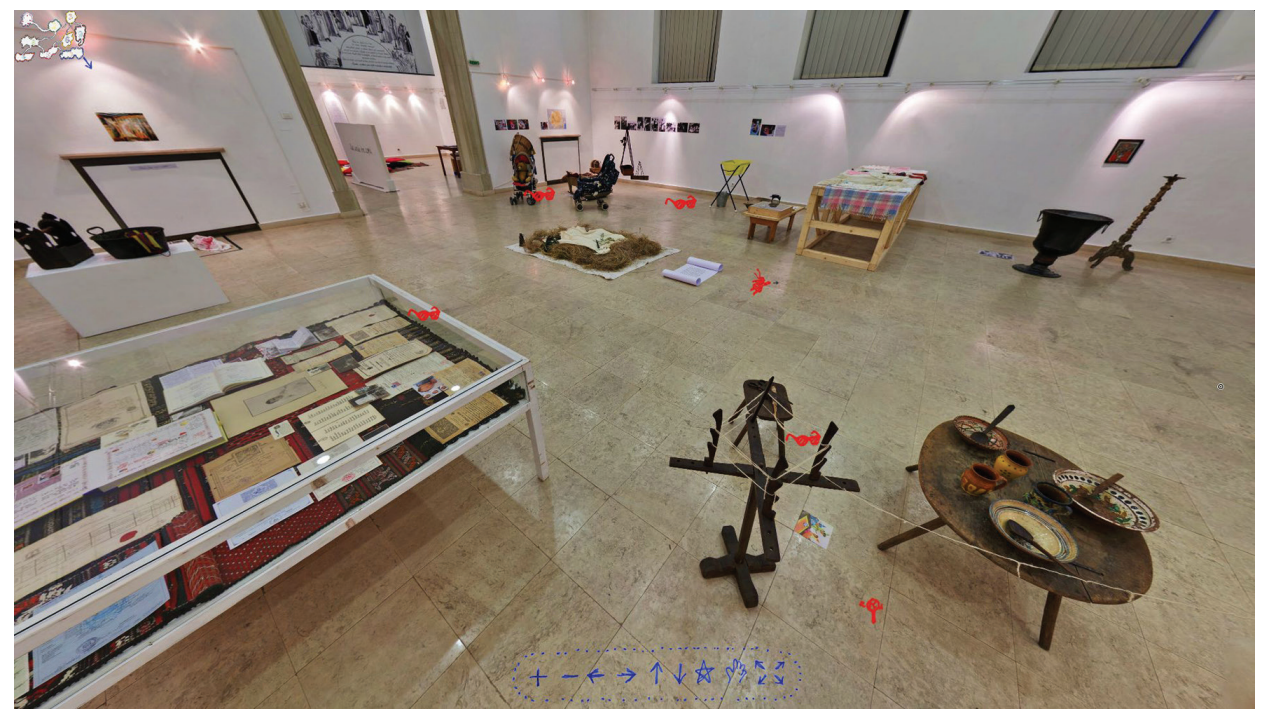

Figure 3. Overview of the exhibition "Coming into the world: From spirits to the Spirit", 2012. Print screen of the virtual museum (http: / / www.childhoodmuseum360.eu/ro). 
Yet, in order to present the exhibition, it is necessary to "walk" through it, mentioning only the most important elements. It starts outside: on the door there is a framed photograph of a door on which a pair of red tassels is stuck with a knife. It was the sign placed by the midwives on the house door, for giving birth easily.

Once stepping over the threshold, we are welcomed by the question "Where do children come from?" (Fig. 4), which sends us to the beliefs regarding pre-birth period, "when children do not really exist, but in fact they are very present in the behaviour of the entire village. They influence the way of living and the way of speaking: suddenly, some words are no longer used and people choose more carefully what they say" (I.P.). This phase is represented by a mask hanging from the ceiling, a symbol of the evil spirits threatening the intrauterine baby, and also by a woman's gown next to it. A short prayer that pregnant women always had with them for protection, as well as all sorts of plants (basil, wormwood, garlic, etc.), also for protective reasons, are sewn on this piece of clothing. The answer to the first question is somehow given by the text handwritten in spiral: "The child in a cabbage, brought by a stork, bought with a sieve of corn flour, dreamt in a flower, brought by water." The exhibition route passes then through an archway featuring an image of life phases as they were represented in the nineteenth century. Childhood is assigned the area under the first step, the message being that, in fact, childhood at the time (nineteenth century),

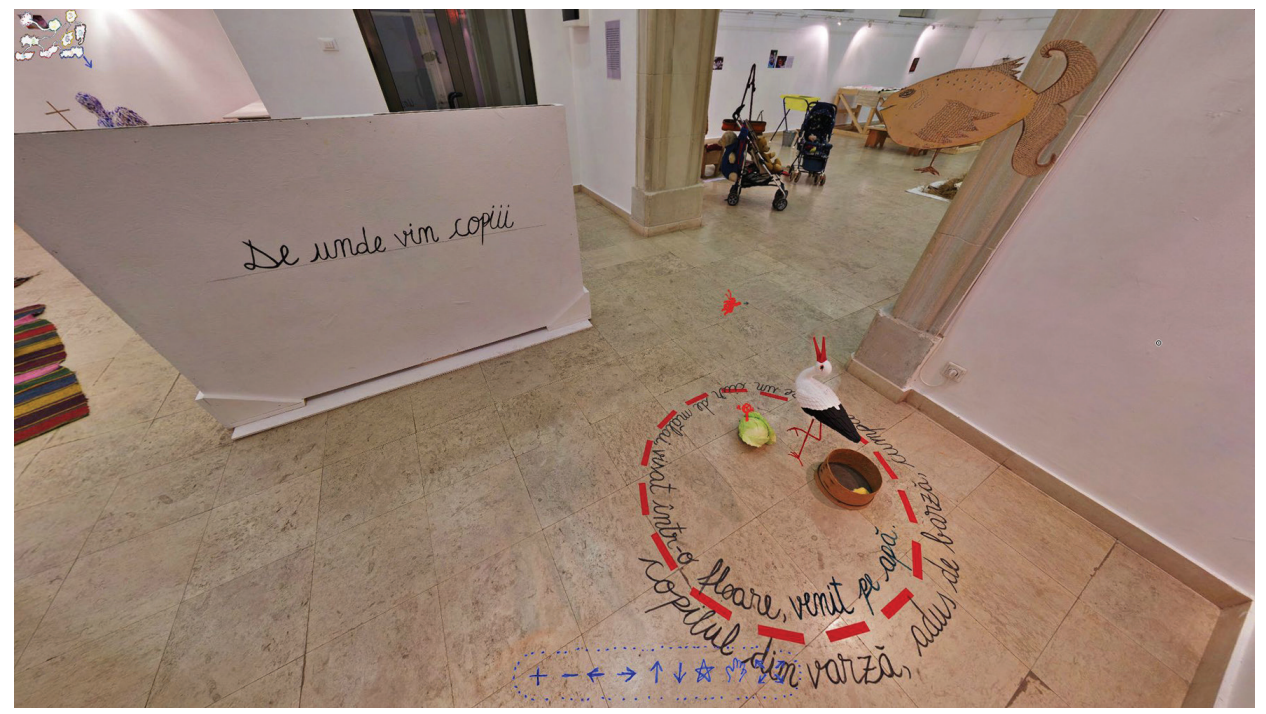

Figure 4. Detail of the exhibition "Coming into the world: From spirits to the Spirit", 2012. Print screen of the virtual museum (http:/ / www.childhoodmuseum360.eu/ro). 
and as the researches in the villages point out, was not given too much attention and space; for example, at a very early age, children would help in the household labours. Thus, it was considered by the curators to be an invention of the modern world.

When entering the second room, attention focuses on its centre. Here the objects present the act of giving birth, which used to take place on a heap of hay, with the woman surrounded by symbolic objects (the father's shirt, an axe placed under the sheets or a bell, as it is believed that strong sounds chase the evil spirits away) meant to ensure an easy labour (Fig. 5). The explanatory text framed as an inscription on a large piece of paper mentions other similar practices and beliefs: "In order to hurry the delivery, the midwife would cut the woman's waistband, in order to remove the baby's obstacles, or would pour water out of an old pot. Could there be a connection between the pot with water and the present pool recommended for painless childbirth?" The exhibition is visually dominated by an icon painted on wood representing Mary, Mother of God, holding the Infant Jesus. In its simplicity, it speaks about maternity.

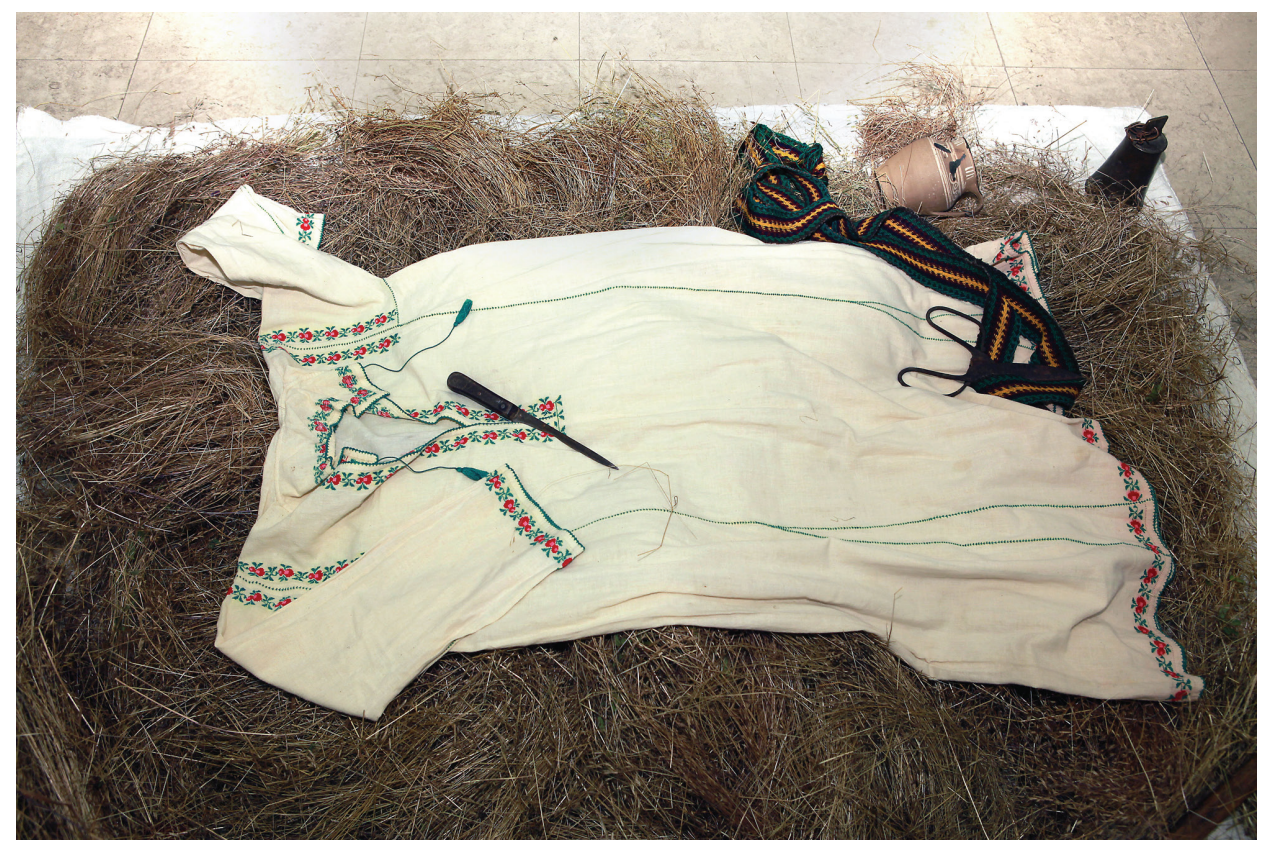

Figure 5. Detail of the exhibition "Coming into the world: From spirits to the Spirit", 2012. Photograph by Marius Caraman, in possession of the Ethnological Archive of the National Museum of the Romanian Peasant. 
On the right side of the exhibition wall other phases prior to birth are displayed. Using the idea of the bloody rag from the 1991 exhibition titled Prunc (Infant), the first thing that can be seen on the right side is such a cloth placed on the floor, in the corner dedicated to abortion. However, right next to it the exhibition goes back to the pre-birth beliefs, namely the practices related to guessing or influencing the gender of the baby. ${ }^{14}$ The texts also refer to contemporary practices, including ultrasound scan. The table with documents related to birth, displayed next, is a good example of combining the old and the new: old and new birth certificates, photos of babies, even a baby diary (Fig. 6). All these talk about the institutionalisation of childbirth and about the contemporary need to produce archive documents. Another comparison between traditional beliefs and pan-European beliefs promoted in mass media (e.g. Disney animated feature film Sleeping Beauty) refers to the Fates in relation to the three fairies from a different area. The still-living practice of placing a mug with water and a slice of bread on the maternity ward window sill to please the Fates, followed by displaying Aromanian ${ }^{15}$ women's simple gesture of placing a loaf of bread

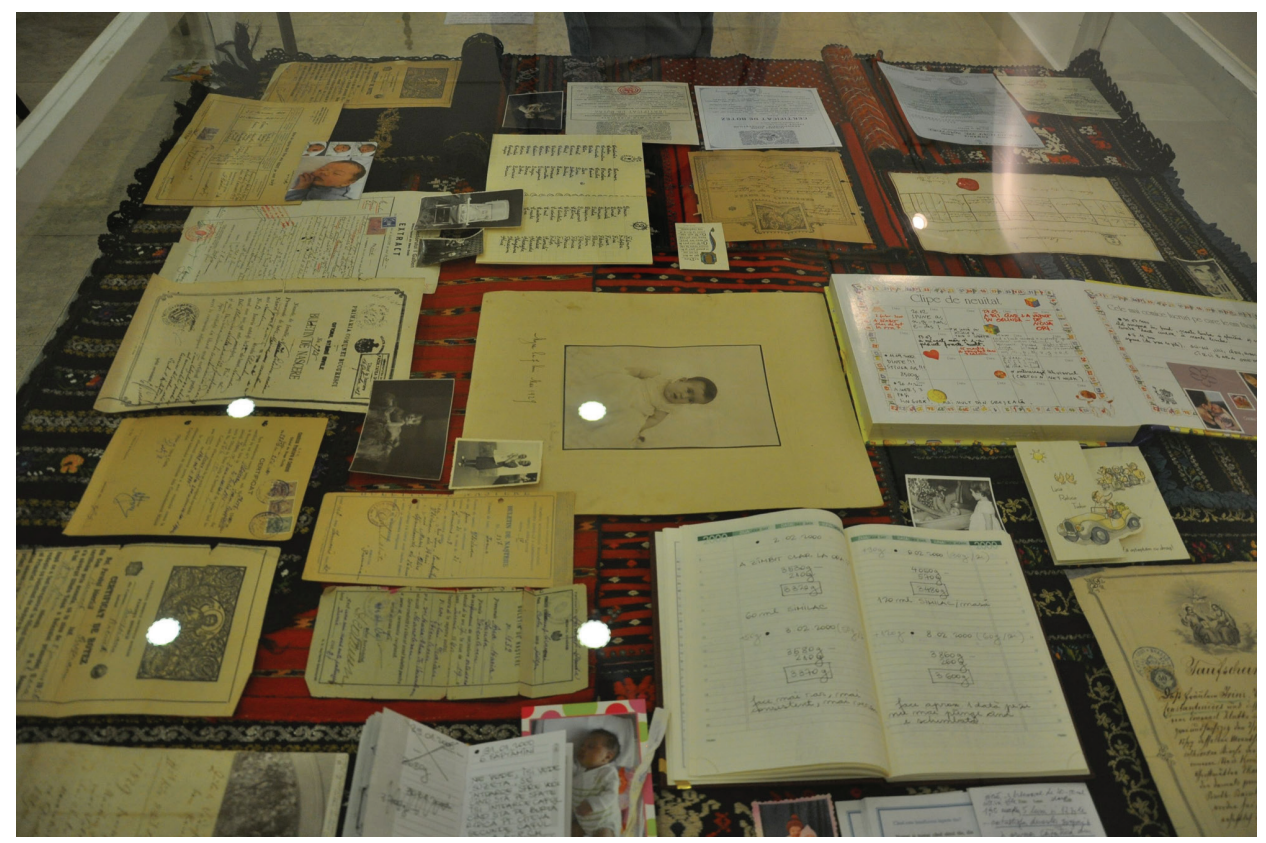

Figure 6. Detail of the exhibition "Coming into the world: From spirits to the Spirit", 2012. Photograph by Marius Caraman, in possession of the Ethnological Archive of the National Museum of the Romanian Peasant. 
into the cradle on the first night after giving birth is also mentioned. Further on, there is a corner dedicated to maternity. There are relevant photographs here, like the one that was taken in a "communist maternity", referring to the abortion ban and to the generation of the "post-decree babies"; there are also some suggestive objects (a baby scale), but also texts of volunteers which appeal to their families' memories in their parents' accounts about the day they were born.

In another part of the room, an installation with old and new objects refers to breast feeding: a few modern baby bottles in contrast to a note saying that "the only baby bottle of the village was the wet-nurse", next to some clay figures representing maternity. An almost iconic object is the shirt with two crosses sewn on the chest. It speaks about the belief that mother's milk could be easily spoilt or stolen by a "milk strigoi" ${ }^{16}$ The two crosses were meant to prevent this from happening.

The next important section is dedicated to baptism - the second birth - into the Holy Spirit. Apart from the religious ritual objects, there are also baby clothes offered by godparents on the baptism day. The clothes displayed were gathered from volunteers, thus their memories bring the exhibition discourse to the present. A small table nearby displays the small gifts given to the guests at the baptising ceremony (mărturii). Next to them there is a wooden bathtub, with its contemporary plastic version, containing small symbolic objects placed in the baby's first bath, such as sugar and honey for the baby's life to be sweet; flour and wheat grains to be prosperous; a coin to provide for richness; flowers and basils for their beauty. The tour in this room finishes with old and new swings, suspended or fixed, back baskets and all sorts of prams and strollers. All these exhibits are illustrated by archive pictures of women holding or carrying children and by some lullabies from the museum's archive, played by a loudspeaker. They are all included in the virtual tour; all you need is to push the button.

The exhibition ends with presenting a dramatic moment, the premature death. "The climax of the first exhibition was embodied in the material and palpable expression of the question 'Where do babies go?"' (Marinescu 2013: 160 ). The answer is given by the angel created and offered by a Romanian artist, Silvia Radu, ${ }^{17}$ a good friend of the museum. The statue points towards the wall displaying a baby's blouse with a cut at the back, reminding of a belief referring to deceased infants. The end is so dramatic, and it touched so many people that it triggered emotional comments from visitors: "I was about to leave the exhibition hall when I saw an object I had missed. The little shirt cut in the back so that the dead baby's wings could grow is simply breath-taking!" (Marinescu 2013: 160). 
The exhibition seen "as a bridge between old and new, a connection between past and present, between the way in which our grandparents were welcomed into this world and the way in which we welcome our own children today" (Marinescu 2013: 160) is a circular course - a course which starts in the "unknown world" where children come from, "shared by both the unborn and the deceased" (I.P.), and which ends with the same world, maybe having a less clear shape, where dead children go as angels. In all these stages, from the protection in the intrauterine period to birth and, later, to the spiritual birth (baptism), rituals, beliefs, and old as well as new practices mark the fragile existence of a new-born baby. Therefore, the curators working on this exhibition selected and exhibited the beliefs considered more relevant, always finding the elements in contemporary culture and in the European area that, from the beginning of the project, they wanted to attach to traditional Romanian culture.

\section{CONCLUSIONS}

One of the purposes of the project Childhood: Remains and Heritage was to awaken some of the public's feelings, as the exhibition was supposed to be "more than a discovery and experience, how shall I put it, [to produce] emotional feedback [in the visitors]" (I.P.). And this happened from the very first exhibition dedicated to childbirth until the last one about games and toys, as "all the museum developed step by step, existed in real form, and then we got to check the reaction of the public" (I.P.). Visitors would leave their comments in a special notebook (Marinescu 2013) and online, on the blog ${ }^{18}$ created back then, at the request of the volunteers. Our public played along. It took only an object, a thought, a text to make them remember their own childhood.

Ioana Popescu recalls:

If childhood moments are situated rather far away in time from the present adulthood, then their remembrance might become a truly exotic journey and the objects that populated that world of the beginning might function as mystery-bearing relics, as triggers of cultural curiosity and surprise. (Popescu \& Bădică 2013: 9)

Childbirth will always be in the stories told by the people close to us and shaped around the objects kept as family treasures. Therefore, for the team of this project, who unexpectedly and surprisingly had the perks of "childlike behaviour", it was important not only to exhibit the objects sheltered by the museum, but also to include a segment of contemporary life, in volunteers' objects and stories, in the photographs from the present or recent past of all the people involved in this 
project. As the exhibitions revolved around the intangible heritage, a relevant role was played by the volunteers' accounts about the beginning of their life, accounts which were recorded, transcribed, and included in the archive of the project. These recordings are an endless source of information and also of joy.

The first exhibition of the Childhood Museum dedicated to birth and continuing all the activities of the Museum of the Romanian Peasant, from its very beginning, was a good start and an example to be followed by the next exhibitions, always including these fragments of contemporary life lived by our volunteers. The success of the Childhood Museum also relies on the fact that it is still in the public eye because of its mentioning in the Romanian language and literature textbook for the 4th grade (Radu \& Jeler 2016), which shows how much the Romanian cultural area needed this approach.

\section{NOTES}

1 Horia Bernea (1938-2000), painter and director of the Museum of the Romanian Peasant from 1990 to 2000.

2 The Museum of the Romanian Peasant, named the National Museum of the Romanian Peasant in 2006, is located in Bucharest, Romania. It is a museum of cultural anthropology dedicated to the peasants' world. The museum was founded in 1990, in the same building that was built in 1912-1941 to host a traditional art museum, but then, in 1953, its collections were moved elsewhere, and in the same building the Museum of the Communist Party was opened (see http://www.muzeultaranuluiroman. ro, last accessed on 15 September 2020).

3 Ioana Popescu (b. 1949), ethnologist and researcher at the Institute of Folklore of the Romanian Academy until 1990. In 1990, she joined the founding team of the Museum of the Romanian Peasant, later coordinating the Department of Ethnological Research.

4 Irina Nicolau (1946-2002), ethnologist and researcher at the Institute of Folklore of the Romanian Academy until 1990. In 1990, she joined Horia Bernea's team to create the Museum of the Romanian Peasant.

5 The excerpts from the interview with Ioana Popescu (aged 71, interviewed in Bucharest on 17 February 2020) are quoted followed by her initials, in order to simplify the endnotes.

6 The Virtual Museum of Childhood (http://www.childhoodmuseum360.eu/ro) is the final result of the project Childhood: Remains and Heritage, carried out by the National Museum of the Romanian Peasant in partnership with the Museum of Lebork (Poland), Romanian Cultural Institute (Romania), and the Association ARTEES (France), financed with the support of the European Union's Culture Programme, between 2011 and 2013. 
7 The team of the National Museum of the Romanian Peasant working on creating the virtual museum: Ioana Popescu (coordinator of the cultural project), Rodica Marinescu, Anamaria Iuga, Raluca Magda Oprea-Minoiu, Liliana Passima, and Cosmin Manolache, together with a team of volunteers of whom I would mention Anca-Maria Pănoiu, Valentina Bâcu, Ioana Barbara Tănase, Simona Gal, and Ioana Corduneanu.

8 The first exhibition was displayed in a different location, because the museum building was being refurbished: the old collection was being packed up (the Museum of the Communist Party) and the space was being prepared for the new exhibition. Back then, Galeriile Orizont belonged to the Union of the Visual Artists in Bucharest.

9 The first attempt to set up a workshop for children failed in "a perfect implosion, but the result was reached, meaning that it was a space where children were totally free and had their creativity stimulated" (I.P.).

${ }^{10}$ Considering all exhibitions organised at the museum between 1990 and 1991, the exhibition Infant is the sixth one, the second one was staged in 1991 (see Bernea 2001: 176).

${ }^{11}$ For instance, the exhibitions displaying archive documents of children presented within the programme "The Image Hall" or the programme "The Village School”, which later led to creativity workshops (Oprea-Minoiu et al. 2017).

12 The first exhibition room under the heading "Coming into the world: From spirits to the Spirit" is dedicated to childbirth. Room 2 is dedicated to children's world under the heading "The small world of the small". Room 3 is about things used by children, "Small things for large needs". Room 4 is about what children do to discover the world around: "Discovering the world, at home and at school". Room 5 is dedicated to childhood challenges: "Relations with the grown-up world", and room 6 is dedicated to children's toys: "Creating the world: Games and toys".

${ }^{13}$ Paris, London, Madrid, Rome, Stockholm, Warsaw, and Lebork, the city of our partner museum. In each of these locations, the exhibition was enriched by at least one added element, a local object, no matter how small, thus growing like an enchanted child in a fairy tale.

14 "If the woman sits on a winder, a boy will be born, if she sits on a tub, a girl will be born" (text in the exhibition).

15 The Aromanians are an ethnic group living in the Balkans (northern and central Greece, southern Romania, central and southern Albania, north Macedonia and southwest Bulgaria), and speaking a Latin-derived language, considered to be a dialect of the Romanian language.

${ }^{16}$ In Romanian villages there is a belief that milk can be stolen by the "milk strigoi" (milk vampires), from animals but also from young mothers.

${ }^{17}$ Silvia Radu (b. 1935) is a Romanian visual artist, ceramist, and painter.

${ }^{18}$ See http://copilariamuzeultaranului.blogspot.com/, last accessed on 15 September 2020. 


\section{REFERENCES}

Bernea, Horia 2001. Cîteva gînduri despre muzeu, cantități, materialitate și încrucișare. [A Few Thoughts about Museum, Quantities, Materiality, and Intersections.] Irina Nicolau \& Carmen Huluță Dosar sentimental. [Sentimental Files.] Bucharest: Ars Docendi.

Marinescu, Rodica 2013. The Childhood Museum - Guestbook. Martor, Vol. 18, pp. 159-162. Available at http://martor.muzeultaranuluiroman.ro/wp-content/ uploads/2015/07/marinescu_site.pdf, last accessed on 15 September 2020.

Martor 2013. Remembering Childhood. Vol. 18. Available at http://martor. muzeultaranuluiroman.ro/archive/revista-martor-nr-18-din-2013/, last accessed on 15 September 2020.

Oprea-Minoiu, Raluca \& Manolache, Cosmin \& Pascu, Ana \& Voicilă, Ciprian \& Grigorescu, Ruxandra \& Florian, Mirela \& Iordan, Beatrice \& Stareș, Lidia \& Bâcu, Valentina 2017. Atelierul de creativitate: A Sentimental Dossier. Martor, Vol. 22, pp. 167-180. Available at https://journals.indexcopernicus.com/api/file/ viewByFileId/197599.pdf, last accessed on 15 September 2020.

Passima, Lila 2013. Childhood: The World Seen through Binoculars. Martor, Vol. 18, pp. 137-160. Available at http://martor.muzeultaranuluiroman.ro/wp-content/ uploads/2015/07/passima_site.pdf, last accessed on 15 September 2020.

Popescu, Ioana \& Bădică, Simina 2013. Two Introductions. Martor, Vol. 18, pp. 9-15. Available at http://martor.muzeultaranuluiroman.ro/wp-content/uploads/2015/07/ popescu_badica_site.pdf, last accessed on 15 September 2020.

Popescu, Ioana \& Nicolau, Irina 1983. Introducere în etnologia primei copilării. [Introduction in the Ethnology of the Early Childhood.] Revista de etnografie și folclor, Vol. 28, No. 1, pp. 46-61.

Popescu, Ioana \& Nicolau, Irina \& Anghelescu, Șerban \& Petrescu Ileana 1991. Prunc. [Infant.] Bucharest: Muzeul Țăranului Român.

Popovăț, Petre 1999. Muzeul de la Șosea. [The Museum Close to the Driveway.] Martor, Vol. 4, Supplement. Available at http://martor.muzeultaranuluiroman.ro/ wp-content/uploads/2017/12/revista-martor-04-1999-supliment.pdf, last accessed on 15 September 2020.

Radu, Alina \& Jeler, Roxana 2016. Limba și literatura română: manual pentru clasa a IV-a. [Romanian Language and Literature: Textbook for the 4th Grade.] Bucharest: Art.

Anamaria Iuga, $\mathrm{PhD}$, is Head of the Ethnology Studies Department at the National Museum of the Romanian Peasant, Bucharest, Romania. She is also a New Europe College Fellow (2019-2020). Her field of research includes the dynamic of material culture and intangible heritage as well as traditional ecological knowledge.

anaiuga@gmail.com 


\title{
REVIEW ESSAY
}

\section{JEWS IN THE RUSSIAN EMPIRE, THE SOVIET UNION, AND THE RUSSIAN FEDERATION}

\author{
T.G. Emelyanenko \& Y.E. Nosenko-Shtein \\ (eds.). Evrei. Moscow: Nauka, 2018. 783 pp. \\ In Russian.
}

\begin{abstract}
Anastasia Kharlamova
Institute for Linguistic Studies

Russian Academy of Sciences, Russia

anastasia_kharlamova@icloud.com
\end{abstract}

\author{
Alexander Novik \\ Museum of Anthropology and Ethnography \\ Russian Academy of Sciences, Russia \\ njual@mail.ru
}

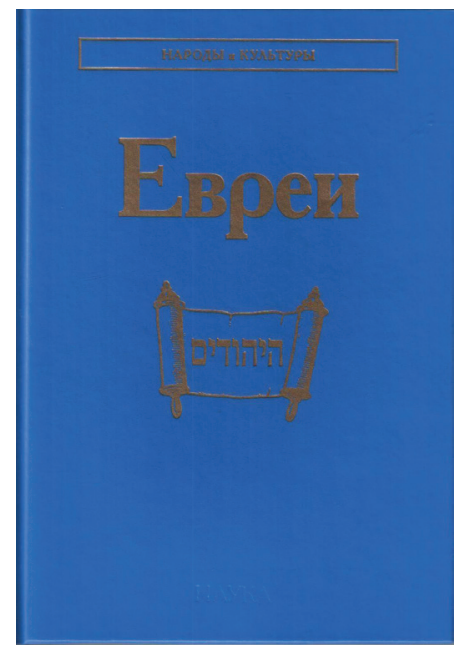

\begin{abstract}
The aim of this essay is to present a comprehensive review of the collective monograph Evrei (The Jews), published in 2018 in the series Narody $i$ kul'tury (Peoples and Culture). The authors give an overview of the modern developments in Jewish studies to acquaint the reader with the background of the reviewed monograph. Every chapter of the monograph is analyzed in detail, taking into account the most recently gathered ethnographic materials, such as the data recorded by Alexander Novik in Priazovye and Crimea in the late 1990s and early 2000s, and the newest publications on the subject, such as a paper by Evgeniya Khazdan on Jewish traditional culture, published in 2018.
\end{abstract}

Keywords: ethnography, Jewish culture, Jewish history, Jewish studies, Jews of Eastern Europe, Jews of Russia, Judaism, review

The collective monograph Evrei (The Jews) was published in the series Narody i kul'tury (Peoples and Cultures), founded in 1992 (editor-in-chief V. Tishkov, executive secretary L. Missonova), which, to a degree, is an important event for ethnographic Jewish studies in Russia and - we would go as far as saying - in Europe. With the available research potential (first of all, the workforce capacity) and the unfailing interest towards Jewish topics expressed by 
researchers working in various academic fields (for example, in Hebrew studies and semitology), it is the ethnology of the Jewish people that turns out to be the least developed field of the study of the humanities in the entire complex of knowledge. In Russia as well as abroad (first of all, in Israel, the United States, Germany, France, Italy, and other countries), quite a few papers on Jewish studies get published every year (Veidlinger 2009; Cohen 2011), but most specialists' academic interests are focused on the issues of history, ancient texts, language, literature and religion, as well as politology and sociology, while studies dedicated to the wide spectrum of ethnographic topics barely ever appear, with the exception of narrowly localized publications focused on specific communities. In the history of Russian ethnographic Jewish studies, starting from the nineteenth century, an important part has been played by papers by local lore researchers, dedicated to various topics of the religious life, festive ritualism, everyday culture, and professional work of Jews living in Russia (note, for example, the expeditions organized by Semyon An-sky). However, regrettably, many materials gathered by local lore researchers and based on primary sources, namely the field surveys of life in specific Jewish communities, either remain completely unknown to the academia or are published with considerable abridgements and many years after their documentation. Over the last decades, we have observed an increase of interest in the study of the languages and culture of the Jewish population of the former Soviet Union (we should especially note the activities of the Sefer Center and the Center for Slavo-Jewish Studies of the Institute for Slavic Studies of the Russian Academy of Sciences (RAS) that both organize yearly complex expeditions with the goal of documenting materials about the Jews and also creating a thesaurus of data about the people that have made an exceptionally large contribution to the history of Europe and other continents) (Amosova 2018).

In this vein, the publication of the volume The Jews is very important and timely. The authoring team led by editors-in-chief T. Emelyanenko and Y. Nosenko-Shtein has managed to display, at a highly professional level, a wide palette of history, religious views, cultural diversity, language, and identity of the Jews of the former Russian Empire and the Soviet Union, modern Russia and its neighboring countries (the former Soviet republics, etc.). The large size of the edition (69.5 standard quires, only the volume Russkie (The Russians) is larger (Aleksandrov \& Vlasova \& Polishchuk 1997; Vlasova \& Tishkov 2014) has allowed them to include a broad variety of topics, traditional for the Peoples and Cultures series. As a result, the book, as a planned synthetic work on the Jews' ethnography, is informative, content-rich, and exceedingly relevant for the academic community. 
In terms of structure, the collective monograph (28 authors have worked on it) is a detailed overview of different topics of history, languages and dialects, traditional culture, rituals, marriage relations, folk beliefs and secret knowledge, calendar feasts, folklore, folk art, and professional culture, modern ethnocultural processes in the former Soviet Union and abroad, outlined in 16 chapters, along with an introduction, a conclusion, a glossary, and highly informative illustrative materials, including a colored inset.

The introduction (T. Emelyanenko, Y. Nosenko-Shtein, V. Tishkov) and the short chapter 1, "The Study of Ethnography and Folklore" (V. Dymshits, Y. Nosenko-Shtein) present, in a very precise way, the goals that the authoring team had set before them, and describe the stages of the study of Jewish people in European countries, including Russia, starting from the 1820s (with the main focus on the work of German and Russian researchers).

In the substantial chapter 2, "Ethnic History from Antiquity to the Collapse of the USSR", the authors (I. Tantlevsky, G. Zelenina, I. Barkussky, Y. Snopov, Y. Suchkova, A. Sinelnikov) have managed, considering the publishing limitations on wordage, to fulfill a very difficult task - to present the main stages of the history of the Jews, including their ethnogenesis, the settling of the Israelites in Canaan, the monarchic period, the Babylon banishment and the Persian period, the Hellenistic age, the early Roman period, the Middle Ages and the early modern period (the Jews of the East, the Jews of the Western Europe: the Ashkenazim and the Sephardim), the ethnopolitical history of Russian Jews before 1917 (with a section dedicated to the early data on Jews in Eastern Europe), the Soviet period (1917-1991) (with a very solid analysis of the events that took place in times of the revolution and the Civil War, the migration of Soviet Jews in the 1920s, the creation of the Jewish Autonomous Oblast, Judaism in the 1920 s and the 1930 s, the Holocaust, the post-war years, the Thaw, the relative liberalization (1953-1967) that followed the death of J. Stalin, and the new wave of crackdown in the Soviet Union (1967-1985), the Perestroika, and the collapse of the Soviet regime (1985-1991)).

This chapter includes a highly interesting section dedicated to the Knaanites the Jews of Eastern Europe in the period of Kievan Rus' (written by I. Barkussky). In the light of the still-ongoing discussion on why medieval Jewish sources before the thirteenth-fourteenth centuries referred to the Slavic countries using the term Knaan (Canaan), the thorough explanation of the folk etymologies with references to the studies by O. Belova, V. Petrukhin, and M. Chlenov looks very convincing (see Belova \& Petrukhin 2008; Chlenov 2014). Here one can recall the mass media's interest in the topic; for example, the documentary film Predki nashikh predkov: Khazary. Po sledu pisem tsaria Iosifa (Our Ancestors' Ancestors: Khazars. Tracing King Joseph's Letters), shot by the All-Russia 
State Television and Radio Broadcasting Company and shown on the Kultura channel (Ancestors 2018), telling, among other things, about the medieval traveler Benjamin of Tudela (late twelfth century) and alluding, through the researchers' academic commentaries, to the image of biblical Canaan, said to become "a servant of servants to his brethren" (Gen. 9:25), and connecting this biblical phrase and the term to the medieval stereotype defining the Slavic peoples as slaves - sclavus, 'slaves'; such nominations and views, though, have been documented since antiquity (p. 66).

Since a book titled Tiurkskie narody Kryma: Karaimy. Krymskie tatary. Krymchaki (The Turkic Peoples of Crimea: Karaites. Crimean Tatars. Krymchaks) was published in the Peoples and Cultures series in 2003 (Kozlov \& Chizhova 2003), the authors have only given concise data on the Karaites (p. 83), whom it would be appropriate to describe as Judaists, according to the long-standing tradition. However, it is not entirely clear why in the section "Karaites in the Russian Empire" the authors of the reviewed collective monograph do not even mention the 2003 publication (one can only learn about it from the list of books in the series at the end of the volume). It is equally unclear as to why there are no facts given concerning A. Firkovich - an iconic figure for the Karaite people. Except that he was a collector of ancient documents and preserved a collection of Karaite manuscripts, an unprepared reader learns absolutely nothing - there is nothing on the dates of his life and death, references to any of his works, let alone the Firkovich Estate - an iconic ethnographic museum in Chufut-Kale (Bakhchisaray) and the symbol of the Karaite identity. For an ethnographic study, it is also odd that apart from the references to historical papers, mentioned practically in every publication dedicated to the Karaites, the collective monograph has no reference to field materials, while over the last decades there have been many studies conducted every year in Chufut-Kale by research teams of ethnographers, philologists, archeologists, etc., from the universities and museums of Simferopol, Sevastopol, Saint Petersburg, Kiev, etc. It would have been useful, in writing a complex book on ethnography, to mention that since the 1990s, there have been, along with all-time archeological and archeographic expeditions, conventions of Karaite youth. As envisioned by the organizers, the latter are to promote the meetings of Karaite young men and women from Crimea, Lithuania, western Ukraine and other centers, including far-abroad countries, for creating new families and preserving the ethnos which is in danger of assimilation. In many academic centers (such as the MAE RAS - Museum of Anthropology and Ethnography of the RAS) field materials on this topic are preserved by the Saint Petersburg department of the RAS Archive and are available for researchers (MAE Archive 2004). 
The chapter "Language and Onomastics" (the sections "Jewish Languages" by A. Polyan and "Onomastics of the Jews of Central and Eastern Europe" by A. Beyder) is written with exceptional professionalism. It quite thoroughly presents a description of Jewish idioms, spoken in the past and currently on different continents, and an analysis of onomastics data, which is a thesaurus of sorts, with materials for further linguistic, ethnological, and historical studies. For example, the paragraph dedicated to surnames presents - very clearly, with flawless references - the system of Jewish anthroponymicon. Only two of the author's statements raise questions, in the description of the adoption of hereditary names in Galicia, according to the state laws, from the end of the seventeenth till the middle of the nineteenth century: "the fraction of "humiliating' names is miniscule (Beider 2004: 27-39)" (p. 195) and "there is an opinion that the Austrian officials, responsible for the assignment of surnames, took bribes for their work. The legend states that there were even precise pricecurrents with special tariffs. 'Beautiful' surnames ... were the most expensive ones. ... The statistical analysis of adopted surnames clearly demonstrates the impossibility of such a 'price-current': the most expensive surnames turn out to be the most widespread, and the wealthy Jews did not constitute a majority in the community" (p. 196). In the former, the author modestly gives no example that would serve as an illustration (considering the plenty of examples in other cases), and as for the latter, it is possible to argue with the author. The 'legend' is passed down much too persistently from generation to generation in the Jewish families in Russia, Germany, Austria, etc.:

You know, I met one of your famous academics here. I have long heard about him. And here there was a conference, a man comes to me, offers his hand and introduces himself: Arsch! You can't help but laugh! He said that their family came from Galicia, and when the Austrian officials started giving surnames to all of the Jews, they demanded money. Who paid them, became Goldfinger or something of that sort. And his greatgreat-great-grandfather refused to pay the officials. So, they wrote him down as Arsch. They accepted the surname and never changed it-it was their conviction, against all odds.

(This interview with a German Jew was recorded in Pristina, Kosovo, in August 2008. The interview was conducted in Albanian and German. MAE Archive 2008: No. 1861)

Along with that, we would also like to note the following. The paragraph "The Origin of Yiddish" has a scrupulous selection of references to almost every statement or conclusion of the author, but the introductory paragraph of the section "Yiddish" has no references to any paper by previous researchers; however, the 
statement that "Yiddish belongs to the Germanic group of the Indo-European languages" is followed by: "about 70 percent of its vocabulary are Germanisms, about 20 percent are Hebraisms (lexemes of Ancient Hebrew and Aramaic origin), about 10 percent are Slavonisms, Romanisms, etc." (p. 179). Considering that in the twentieth century, most researchers wrote about 80 or more percent of German vocabulary in the corpus pool of Yiddish, it would have been appropriate for the author to include a reference to the source of this statistic or to refer to his own calculations.

The chapter "Calendar Feasts" (S. Amosova, M. Kaspina) is written very thoroughly, which is expected of a collective work with the main focus on the ethnographic aspect. The study generalizes the vast materials gathered by the predecessors and presents the field materials gathered by the authors themselves on the enormous territory from the Baltic states to Moldova, from western Ukraine to the central regions of Russia and Caucasus. This approach marks a high level of the problematics' analysis.

However, we would also like to mention some unfortunate mistakes. For example, there is the description of the feast of Sukkot ("Sukkot is described in the Torah as the feast of the new harvest, which lasts a week from the 15 th till the 22nd day of the month of Tishrei" (p. 325). Along with Shavuot and Pesach, Sukkot is one of the Three Pilgrimage Festivals, related to the cycles of the agricultural year and the pilgrimage to the Temple of Jerusalem (Ex. 23:14-17, 34:22; Lev. 23:34-36, 39-43; Num. 29:12-38; Deut. 16:13-15). On the feast of Sukkot, King Solomon brought about the consecration of the Temple of Jerusalem. On the last day of the feast, they start to pray for rain in the synagogues. The Bible dictates to celebrate Sukkot in the following way: "You shall observe the Feast of Tabernacles seven days, when you have gathered from your threshing floor and from your winepress" (Deut. 15:13) (p. 325). Paying enormous attention to the religious aspect of the feast and quoting many memoirs and records of lore researchers, gathered in Belarus, Ukraine, Moldova, and Russia, the authors, for some reason, do not give the translation of the names of herbs and fruits significant for the tradition:

In the Book of Leviticus it is said concerning the feast of Sukkot: 'And you shall take for yourselves ... the fruit of beautiful trees, branches of palm trees, the boughs of leafy trees, and willows of the brook; and you shall rejoice before the LORD your God for seven days' (Lev. 23: 39-43). This instruction is probably related to the agricultural nature of the feast and the motive of the growth of fertility. In the later Jewish tradition these herbs are called arba minim (Hebrew for 'four species'). They include etrog (a species of citrus), a bough of myrtle, the willow, and lulav (a palm frond). 
Among the ceremonies and rituals of the feast, the memoirs and tales describe the custom of blessing the etrog, lulav, and other herbs. (p. 327)

Actually, etrog is the citron, not just "a species of citrus". It can be found out not only by consulting an available Jewish encyclopedia, but even by a simple search in the popular, if not always academically faultless Wikipedia. And there are special studies of the citron in the Jewish tradition in the academic informational field (such as Novik \& Domosiletskaya 2019).

The chapter "The Material Culture of the Jews of Eastern Europe" consists of the following sections: "Crafts" (M. Hakkarainen), "Settlements, Houses" (E. Kotlyar), "Cemeteries" (V. Dymshits), "Traditional Clothing”(V. Dymshits), and "Food" (D. Vedenyapina). In such a structure of the chapter and in the collective monograph in general, the section dedicated to cemeteries somehow drops out. According to the logic of the treatment of the material, it would have been more accurate to place that section in the chapter that has a subsection "Funerary Rituals: Concepts of Death" (S. Amosova, M. Kaspina) and, on the whole, to create another block of paragraphs focused on cemetery culture and the cycle of commemoration. Speaking of which, Jewish commemoration ceremonies are summarized in the section "Concepts of a Dead Person's Soul" (p. 296), which does not completely correspond with its contents.

The abovementioned section, "Traditional Clothing", is a high-quality description of the complexes and specific elements of clothing of the Jews of the Near East and the diaspora in other parts of the world. This analysis begins with antiquity, the mentions of clothing in the books of the Old Testament and the pictures on Assyro-Babylonian monuments are taken into account. Though there are many references to biblical texts, this paragraph (as well as the introductory part, dedicated to the Jews' ethnogenesis) does not mention the texts of the $\mathrm{PhD}$ (candidate) dissertation and the following monograph by I. Bogoslovskaya, Odezhda narodov bibleiskikh stran (po drevneegipetskim istochnikam XVI-XI vv. do n. e.) (The Clothing of the Peoples of Biblical Countries (With the Data from Ancient Egyptian Sources of the 16th-11th Centuries BCE)) (Bogoslovskaya 1995). These studies are just dedicated to the differences between the clothing of the Shasu tribes, the residents of Canaan, etc., and others, which contradicts the conclusion given in the collective monograph: "The clothing of the Jews in antiquity ... was not different from the clothing of other Semitic peoples of the Near East" (p. 241). Both authors (V. Dymshits and I. Bogoslovskaya), by the way, are from Saint Petersburg, and the texts of I. Bogoslovskaya's dissertation, its synopsis and the book itself were quite available during the preparation of the volume The Jews. 
Jewish clothing is the topic of the sections in chapter 11, "Non-Ashkenazi Ethnic and Ethnocultural Groups: Georgian Jews" (K. Lerner, T. Emelyanenko), "Bukhara Jews" (T. Emelyanenko), and "Russian Judaists" (A. Lvov, N. Semenchenko). The clothing and jewelry of the Bukhara Jews are analyzed at a very high level, very conclusively and in great detail (pp. 481-503); the section offers plenty of illustrative materials (mainly the late nineteenth-early twentieth-century photographs kept at the Russian Ethnographic Museum (REM) and the MAE, and the pictures of actual Bukhara exhibits from the REM, as well as the photographic prints by the section's author). This fact demonstrates that T. Emelyanenko has conducted a great deal of research for writing this part of the collective monograph (here one should also mention that in 2012 this author presented her doctoral dissertation on the topic Traditional Clothing of Bukhara Jews: The Problems of Ethnocultural Identity).

Chapter 9, "Folklore of the Jews of Eastern Europe", is written very thoroughly. It consists of two sections: "Narrative Folklore" (V. Dymshits) and "Traditional Musical Culture" (E. Khazdan). It is very pleasing that the collective monograph pays so much attention to the spoken folk tradition and musical culture of the Jews, since over the last years, folkloristics has been leaning more towards anthropology in the world's academic practice, and the study of folklore in its classical meaning has been replaced by research at the intersection of different fields of humanities.

In the section "Narrative Folklore", the author of the text justly remarks that "the phrase 'Jewish folklore' has something suspicious in it for the romantic concept of spoken folk tradition. The Jews of Eastern Europe were definitely not suitable for the role of traditional preservers of folklore. First, they were mostly residents of cities, second, all of them were literate, with not just the 'holy' and edifying books available to them, but the simply entertaining ones as well, both in Ancient Hebrew and in Yiddish" (p. 345). It took some time before the Jewish intelligentsia, educated at the best universities of Europe and inspired by the ideas of the Enlightenment and emancipation, stopped being ashamed of the place where they came from, with their idioms, solidified cultural stereotypes and 'display of superstitions' (for which it took folk songs, legends and fairy tales), and in the late nineteenth-early twentieth centuries began perceiving them, under the influence of Romanticism and Symbolism, as the undoubted cultural heritage of their ancestors. Regrettably, the paragraph "Fairytales" in this section is too laconic; the author merely brings up the importance of the borrowings from the folklore of Germans, Belarussians, Ukrainians, etc., in this genre. The fact that traditional texts in Ancient Hebrew and Aramaic are one of the sources of the Jewish fairytale is described very concisely (p. 346). 
Finally, it is completely incredible for the reader that the author, while speaking of fairytales, does not reference the classical work of V. Propp (in this case it is not criticizing - it is not necessary to pass the well-known passages from article to article - it is just an observation!).

The structure of the abovementioned section, "Narrative Folklore" (pp. 345363), does not look fully clear to the reader. For example, the chapter title, "Folklore of the Jews of Eastern Europe", is followed by the section title "Narrative Folklore" (it is also reflected in the table of contents). The section is, as it seems, divided into paragraphs - we mentioned "Fairytales" as one of them. However, the paragraph "Folk Book in the Culture of the Jews of Eastern Europe" is followed by what looks like another section (or paragraph), "Narrative Folklore in Spoken Popular Tradition" (feel the difference), which, in turn, contains paragraphs such as "Magical Fairytales, Fairytales for Children", and others. Without a doubt, the author of the text and the editors-in-chief should have given more attention to the structure of the collective monograph.

The section "Traditional Musical Culture" is written very professionally. Its author, Evgeniya Khazdan, is an acknowledged authority on the subject hardly studied by specialists, since it demands multifaceted knowledge - in the field of music as well as religious studies and ethnology. In the West, researchers who work in the field of ethnomusicology have to have two educations, as a rule - usually a diploma (preferably at the MA level) of a conservatory, and a PhD degree in the field of ethnology or cultural and social anthropology. In Russia, as well as in the republics of the former USSR, such criteria have not yet been established. That is why we can rarely encounter a specialist of the level of E. Khazdan. In the West, by the way, due to a variety of reasons, very few academics study Jewish musical tradition. Therefore, the possibilities of studying this topic - in Russia and in the West - are practically equal. Such a solid section on musical culture is a credit to the collective monograph.

E. Khazdan traces the musical culture of the Jews who lived on the territory of the former Russian Empire, analyzing the features specific to each group that had formed due to the contacts with neighboring peoples. There are extremely few publications for the author to rely on, as since the mid-1930s there has been a gradual withering of the study of Jewish tradition in the USSR, because of the inner political reasons. In the years that followed the Second World War, there was an unspoken ban on the research on Jewish folklore, traditions, etc. The scarce publications on the musical folklore of the Jews of Russia, Ukraine, and Belarus, which got published in the West and in Israel, were secretly exported out of the USSR as manuscripts - such was the case, for example, with the works of the folklorist Moshe Beregovski (1892-1961) (Beregovski 1968; 
Beregovski \& Lerner 1970), who had gathered song lyrics and tunes in the field for many decades (p. 365). The situation with the research of Jewish musical folklore had radically changed with the start of democratic transformation in the USSR in the mid-1980s, but a considerable part of the cultural heritage had been completely lost by that time.

E. Khazdan analyzes the connection between musical traditions and conducting of rituals, rich in religious meaning. The author focuses more on this topic in her other work (Khazdan 2018). "One of the most important mechanisms that form the cultural memory in Jewish tradition is the consistent, systematic return to the main text and its actualization" (ibid.: 55).

In the paragraph "Songs" the author gives an explanation for the main differences between the Jewish traditional song and the main corpus of the folklore of Eastern Slavs. For example, in a traditional Jewish community, men and women could not sing together due to the active Talmudic ban for men's listening to women singing. Furthermore, Jewish songs are mostly one-voiced, soloistic. It can be explained by the fact that in Jewish culture, there were no situations that would unite people in permanent groups, as it happened in the peasants' everyday life among the Slavs, where people were united for working together in the fields, at spinning during winter evenings, at the plaiting of wood wool, etc.

Chapter 10, "Folk Art of the Jews of Eastern Europe" (V. Dymshits) encompasses the sphere of everyday life, enormous in its contents and complexity. The author analyzes the iconography and symbolism of Jewish art, ritual utensils, printed and handwritten books, furnishings of synagogues, artistic textiles (that he calls "synagogal objects of fabric"), "synagogal jewelry" (not the exact term either!), "house jewelry" (one has to read the entire text to understand - it stands for jewels produced at home), "relief sculptures of grave stelae" (it means the decorations of grave monuments). It is perfectly obvious that this chapter could have been the central one in the collective monograph - exactly because of the clarity of the currently and possibly available materials. However, it is a rather crumpled text, badly proofread by the author himself. We will just give a fragment of the beginning of the chapter as an example: "The art language of the folk art of the Jews of Eastern Europe has formed by the influence of a variety of differently angled impulses and influences" (emphasis ours) (p. 378). The content is not far behind the shape: many explanations offered are shallow. For example, while explaining the symbolism of the eagle (and an entire paragraph is dedicated to this!), V. Dymshits does not give any references to the previous researchers, and the reader has to fully trust the author's opinion. But even these things are not what depletes and over-simplifies the contents of the chapter. It has practically no illustrations! One can, of course, accept this 
in a philosophical tractate. But how can one speak of ritual utensils and not give a single picture of them? Or what should the reader imagine while reading the paragraph on the Jews' jewelry? Or, likewise, on graveside stelae... This is not a matter of some exclusive materials for which it is very difficult to supply illustrations. Everything that the author talks about is very well represented in the museum collections of the REM and other collections, in Russian and foreign synagogues, at Jewish cemeteries, etc.

Chapter 12, "Professional Culture", consists of two sections: "Book Culture" (S. Yakerson) and "Education" (A. Lvov). The section dedicated to the Jewish book as a phenomenon provides an analysis of the genesis of the writing system and book-printing, with specific subsections about the state of affairs in the seventeenth-eighteenth centuries and about Jewish book-printing on the territory of the Russian Empire. Close attention is given to the topics of the books of the traditional Jewish library. The chapter is very informative in general, despite the intended brevity of the exposition.

The collective monograph The Jews as a whole is a complete work of likeminded researchers, who completed the task set in a highly professional way. The publication was planned very skillfully from the beginning, and the best specialists working on different problems of Jewish Studies, including Hebrew Studies and semitology, were invited as authors. The published volume is wellstructured, which is in no small part a credit to the editors-in-chief. The book became a true collective monograph and not a collection of articles on Jewish Studies, as it often happens with a large number of researchers at work.

However, we would also like to turn our attention to some flaws or mistakes of the authors of the collective monograph.

The Jews in the Russian Empire / the Soviet Union / modern Russia have been known as good craftsmen and merchants, businessmen and financiers, who made up a large percentage of the population in towns and, to a lesser degree - and only in some districts - in villages. Thanks to their commercial operations, covering the entire country in a well-developed network, trade, banking, service industry and specialized education have flourished. For a long time - until the industrial revolution at the end of the eighteenth century crafts had been one of the bases, the economical foundation (along with agriculture) of the existence of a major part of the humanity. Jewish craftsmen supplied with goods a good part of the population of the huge country, most of whom were peasants. Therefore, in a book dedicated to the Jews of Russia, one expected to find a substantiated analysis of their professional activities, with multiple examples and statistics. But the section dedicated to crafts looks entirely disproportionate to the size of the publication (pp. 201-207). Crafts as the economical basis of society in certain periods of history would obviously 
demand a more careful analysis. Clearly, such brevity was not the idea of the author of the section (M. Hakkarainen), but rather was dictated by the editors' strategy. On the whole, such a situation is characteristic of other volumes of the Peoples and Cultures series as well. It is not quite understandable why this section does not use illustrative materials, which could have enriched the contents significantly. For example, at the MAE RAS and at the REM they keep quite rich collections of photographs and prints of the photographers who worked with the Jews of Belarus and Ukraine, as well as Central Asia and Caucasus, at the end of the nineteenth and the first decades of the twentieth century (such as the photographs of Jewish workers from the village Mezherichi, the town Shepetovka, etc., taken by Z. Yudovich). These collections are a wonderful treasury of facts of everyday life, which has preserved the Jewish people's life on the cusp of the nineteenth and twentieth centuries for the future generations. The inclusion of the materials of the photographers who had worked in the field would have allowed the authors to present a much more precise image of the household and trade activities of the Jews (among whom, for example, there were many weavers, laborers, and representatives of other professions in Belarus and Ukraine) (Novik \& Golant 2018).

The collective monograph contains only scant information on the history and functioning of Jewish communities in Russia. Of course, this topic would have demanded colossal efforts from the authoring team and participation of other specialists. But for a volume that aspires to be a complex ethnological description of the Jewish people, such a chapter (not even a section) is absolutely necessary.

Rather superficial is the writing on the creation of Jewish kolkhozes in the late 1920s and early 1930s (the section "Jews in the USSR (1917-1991)" by Y. Snopov and Y. Suchkova). The conclusion given in the collective monograph, "the events related to the collectivization and industrialization led to the migration of Jews from the kolkhozes, which were getting poorer, to the cities" (p. 114), can be argued with. In Ukrainian Cis-Azov region, for example, in the Zaporizhia Oblast, following the order of the party leaders, they created kolkhozes where Jews worked. These kolkhozes were quite prosperous. The dissolution of this kind of collective enterprises was due not to the Jews' unwillingness to work on soil, but rather to the command of the party, who began to see these nationbased kolkhozes (there were also Bulgarian, Albanian, Czech, etc.) as a threat to the Soviet regime. The change in national politics led to the liquidation of Jewish kolkhozes in the European part of the USSR. The field materials gathered in Hesed Velvele (Melitopol) in 1998 by one of the authors of this review, Alexander Novik, together with Y. Ivanova and I. Uvarov, and preserved in the archives of the MAE RAS prove exactly this and contradict what is said in the collective monograph The Jews (MAE Archive 1998: No. 1726). 
The attitude of the Soviet Jewish community on the brink of the Second World War is not outlined very clearly. The enormous losses among the Jews can be explained in no small part not just by the suddenness of Nazi Germany's attack on the USSR, but also by the unwillingness of many leaders and functionaries of Jewish communities, as well as people of authority, the intelligentsia, etc., to acknowledge the threat coming from the Third Reich. This is also stated in the narratives recorded during fieldwork on the territories occupied during the Great Patriotic War (MAE Archive 1998: No. 1726).

There are some very unfortunate errors in the book. For example, in the chapter "Non-Ashkenazi Ethnic and Ethnocultural Groups", in the section "Georgian Jews" (K. Lerner \& T. Emelyanenko), in the paragraph "Birth and Circumcision", the following phrase rings quite odd: "The mother's father or elder brother usually stood godfather to the firstborn child. On the eighth day they performed the rite of initiation - the circumcision" (p. 429). Considering that the section itself is written with obviously a good grasp of the material, such phrases and nominations ("godfather") are a sign of a cursory check of the text.

The lack of attention for details reveals itself in the diversity among the descriptive texts for the photo-illustrative data published in the book. Obviously, the large size of the monograph and the considerable number of authors who worked on it have contributed to the fact that some illustrations come with the author's name and the date of the photograph, while others lack this information or only have fragments of it.

In several sections of the collective monograph (for example, in chapter 7, "Folk Beliefs and Knowledge", the section "Traditional Medicine" by N. Kireyeva) there are very few references to field research and field data archives, which is seemingly obvious when one writes on such a topic. There are quite numerous references to the available literature in the text, but, with the exception of the works by O. Belova, most of it was created at the beginning of the twentieth century.

To conclude, it is important to note that the new volume of the Peoples and Cultures series, dedicated to the Jews, is a long-awaited work of an authoring team that has spent many years studying the Jewish people and Jewish culture. By the way, it is the only monograph in the series whose title is written on the cover not just in Russian and in the Cyrillic script, but in the idiom as well. The book is already in high demand among Russian and foreign researchers, as well as all the other interested readers. 


\section{ACKNOWLEDGEMENTS}

This paper was funded by grant 19-18-00244 of the Russian Science Foundation.

\section{SOURCES}

Ancestors 2018 = Predki nashikh predkov: Khazary. Po sledu pisem tsaria Iosifa. [Our Ancestors' Ancestors: Khazars. On the Tracks of King Joseph's Letters.] Available at https://player.vgtrk.com/iframe/video/id/1851072/start_zoom/ true/showZoomBtn/false/sid/kultura/?acc_video_id=episode_id/2000073/video_ id/2059806/brand_id/63419, last accessed on 24 March 2020.

MAE Archive 1998 = Novik, Aleksandr 1998. Albantsy Ukrainy. Zaporozhskaia, Odesskaia oblasti. Polevye zapisi. Avtograf. [The Albanians of Ukraine. Zaporizhia Oblast, Odessa Oblast. Field Records. Autograph.] Arkhiv MAE RAN, K-1, op. 2. No. 1726. $202 \mathrm{l}$.

MAE Archive 2004 = Novik, Aleksandr 2004. Greki, karaimy, arnauty Kryma: Polevye zapisi. Avtograf. [Greeks, Karaites, Arnauts of Crimea: Field Records. Autograph.] Arkhiv MAE RAN, K-1, op. 2. No. vremenno b/n. 32 l.

MAE Archive 2008 = Novik, Aleksandr 2008. Albanskie remesla $v$ Kosovo. Polevye zapisi. Kserokopiia s avtografa. [Albanian Crafts in Kosovo. Field Records. Copied from Autograph.] Arkhiv MAE RAN, K-1, op. 2. No. 1861. 38 l.

\section{REFERENCES}

Aleksandrov, Vadim \& Vlasova, Irina \& Polishchuk, Ninel (eds.-in-chief) 1997. Russkie. [The Russians.] Moscow: Nauka.

Amosova, Svetlana (ed.-in-chief) 2018. Evrei pogranich'ia: Smolenshchina. [Jews of the Border Regions: Smolensk Region.] Moscow: Tsentr Sefer \& Institut slavianovedeniia RAN. Available at https://sefer.ru/rus/publications/smolensk.php, last accessed on 24 March 2020.

Beider, Alexander 2004. A Dictionary of Jewish Surnames from Galicia. Bergenfield, NJ: Avotaynu.

Belova, Olga \& Petrukhin, Vladimir 2008. "Evreiskii mif" v slavianskoi kul'ture. ["Jewish Myth" in Slavic Culture.] Moscow: Mosty kul'tury; Jerusalem: Gesharim. Available at https://inslav.ru/images/stories/pdf/2008_Belova_Petruxin.pdf, last accessed on 25 March 2020.

Beregovski, Moshe 1968. Zeyer lid iz dergangen tsu undz. [Their Song Has Reached Us.] Sovetish heymland, No. 4, pp. 54-56.

Beregovski, Moshe \& Lerner, Ruvim 1970. Yidishe folks-shafung beys der foterlendisher milkhome. [Jewish Folk Art during the Patriotic War.] Sovetish heymland, No. 5, pp. $143-149$. 
Bogoslovskaya, Irina 1995. Odezhda narodov bibleiskikh stran (po drevneegipetskim istochnikam XVI-XI vv. do n. e.). [The Clothing of the Peoples of Biblical Countries (With the Data from Ancient Egyptian Sources of the 16th-11th Centuries BCE.] St. Petersburg: MAE RAS.

Chlenov, Mikhail 2014. Kenaanity: Evrei v srednevekovom slavianskom mire. [The Knaanites: Jews in the Medieval Slavic World.] Moscow: Mosty kul'tury; Jerusalem: Gesharim.

Cohen, Erik H. 2011. The Jews of France Today: Identity and Values. Leiden: Brill. https://doi.org/10.1163/ej.9789004207530.i-238.

Khazdan, Evgeniya 2018. The Traditional Culture of the Jews of Eastern Europe: The Mechanisms of Transmission. In: A. Novik \& N. Golant (eds.-in-chief) Evreiskie diaspory $v$ Evrope i mire: polevye $i$ istochnikovedcheskie issledovaniia: sbornik statei. [Jewish Diasporas in Europe and the World: Field and Source Studies. A Collection of Articles.] St. Petersburg: MAE RAS, pp. 52-67.

Kozlov, Semyon \& Chizhova, Liudmila (eds.-in-chief) 2003. Tiurkskie narody Kryma: Karaimy. Krymskie tatary. Krymchaki. [The Turkic Peoples of Crimea: Karaites. Crimean Tatars. Krymchaks.] Moscow: Nauka.

Novik, Aleksandr \& Domosiletskaya, Marina 2019. Tsitron v iazyke i kul'ture grekov i albantsev Khimary. [Citron in the Language and Culture of the Greeks and Albanians of Himara.] XLVIII Mezhdunarodnaia filologicheskaia nauchnaia konferentsiia. Sankt-Peterburgskii gosudarstvennyi universitet. G. SanktPeterburg, 18-27 marta 2019 g. Balkanistika, neoellinistika i vizantinistika. [XLVIII International Philological Academic Conference. Saint-Petersburg State University. Saint-Petersburg, March 18-27, 2019. Balkan, Neohellenic and Byzantine Studies.] Conference presentation.

Novik, Alexander \& Golant, Natalia (eds.-in-chief) 2018. Evreiskie diaspory v Evrope i mire: polevye i istochnikovedcheskie issledovaniia: sbornik statei. [Jewish Diasporas in Europe and the World: Field and Source Studies. A Collection of Articles.] St. Petersburg: MAE RAS.

Veidlinger, Jeffrey 2009. Jewish Public Culture in the Late Russian Empire. Bloomington: Indiana University Press.

Vlasova, Irina \& Tishkov, Valery (eds.-in-chief) 2014. Russkie. [The Russians.] Izdanie 2-e pererabotannoe. Moscow: Nauka.

Anastasia Kharlamova is a $\mathrm{PhD}$ student at the Institute for Linguistic Studies of the Russian Academy of Sciences. Her research interests are spontaneous speech phonetics, Balkan languages, Germanic languages, Old Church Slavonic and palaeography.

anastasia_kharlamova@icloud.com

Alexander Novik is PhD, Head of the Department of European Studies, Peter the Great Museum of Anthropology and Ethnography (Kunstkamera) of the 
Russian Academy of Sciences, and Associate Professor in Albanian Philology and Balkan Ethnology at the Department of General Linguistics, Saint Petersburg State University, Saint Petersburg, Russia. His research interests are in the field of traditional and modern culture, ethnolinguistics, ethnic and religious minorities, folk costume, and festivity.

njual@mail.ru 


\section{JOINT ESTONIAN-BELARUSIAN WEBINAR "MISSION POSSIBLE V: ADAPTATIONS, TRANSFORMATIONS, AND FUNDAMENTAL ASPECTS OF VERNACULAR CULTURE”}

Academic cooperation between the Estonian Literary Museum and the National Academy of Sciences of Belarus has lasted for more than five years and has resulted in a number of academic events: conferences, seminars, workshops, etc. Previously these events took place either in Estonia or in Belarus, giving all the participants an opportunity to meet face-to-face and discuss their research during the conference sessions and social events. This year's extraordinary circumstances have affected the format of the academic meeting. As international travelling was restricted, the fifth seminar in the "Mission possible" project was held online in MS TEAMS environment. While limiting the possibilities of informal socializing, such a format has nevertheless proved to be a convenient means to bring together scholars with different backgrounds and discuss the important issues of folk culture.

The topic of the seminar "Adaptations, transformations, and fundamental aspects of vernacular culture"1 implied that folklore is deeply embedded in everyday life and swiftly reflects any changes in social, political, economic, and cultural spheres. While these transformations might be subtle and less noticeable than the particular events that stimulate them, the adaptive strategy of folklore is crucial for our understanding of how society functions on a grassroots level. The papers presented at the seminar discussed both recent phenomena and the fundamental aspects of Estonian, Belarusian, and world folklore.

The seminar consisted of three panels which ran in a single track, giving everyone an opportunity to listen to all the presentations. The first panel titled "Vernacular replies to contemporary challenges" reflected on digital and real-life adaptations of folklore to the changes in our everyday life. The panel consisted of three presentations. Mare Kalda's presentation "Fake events as a part of internet folklore" analysed dozens of humorous Facebook events that became popular among Estonian young people in 2018, and placed them into the framework of folk genres classification. The focus on humorousness was also prominent in the subsequent presentation by Piret Voolaid and Anastasiya Fiadotava. In their paper "Comparing virtual activities of Estonian and Belarusian football fans during COVID-19 pandemic" they emphasized the positive aspect of communication between football clubs and their fans. The impact of COVID-19 pandemic on folk culture was also explored in Dzianis Filipchyk's paper "Wearing the namitk $a^{2}$ amidst the pandemic". The presentation illustrated the dynamic adaptations of an old ritual to the new circumstances.

The presenters of the second panel titled "Temporal and spatial dimensions of folklore" combined folkloristic, ethnographic, and semiotic methods to interpret verbal narratives and folk practices. The panel started with Mare Kõiva and Alena Bohaneva's paper titled “The Pied Piper. The amazing life of a medieval event: Estonian 
and Belarusian parallels". The authors underscored that the motif of the Pied Piper of Hamelin was recurrent not only in Western European, but also in Slavic and Finno-Ugric folklore. Ilya Butov's presentation, "The miracle of icons renewal / myrrh-streaming as a sign of the Great Patriotic War" compared the records of miraculous icons in the 1940s and similar events in contemporary Belarus. Yuri Unukovich in his presentation "(De)constructing an ethnographic region: The case of the Vilnius region" provided an extensive overview of ethnographers' efforts to define the boundaries of cultural areas that become particularly crucial in the border regions. The paper "On the semiotics of memory and presence in the folk culture of Belarusians" by Siarhei Hruntou uncovered the deep layers of memorial practices and illustrated how memory is actualized via everyday practices and objects.

The final session titled "Folklore as a form of protest" covered some of the most recent and popular examples of Belarusian and world folklore. Much of the session was dedicated to the use of folklore in the Belarusian protests of 2020 against the falsifications at the elections and the police brutality. Tatsiana Valodzina in her presentation "Rites of passage and modern forms of protest" interpreted the posters, slogans, costumes, and installations created by the protesters within the framework of the rites of passage. She showed how the carnivalesque nature of Belarusian protests and the use of sexual and chthonic symbols point to the transition between the old and the new. Similar datasets were discussed by Nastassia Hulak, whose presentation "Folk art as a form of public protest presentation" focused on the messages of Belarusian protest folklore and the democratic values behind them. Yanina Hrynevich's paper "Kupalinka

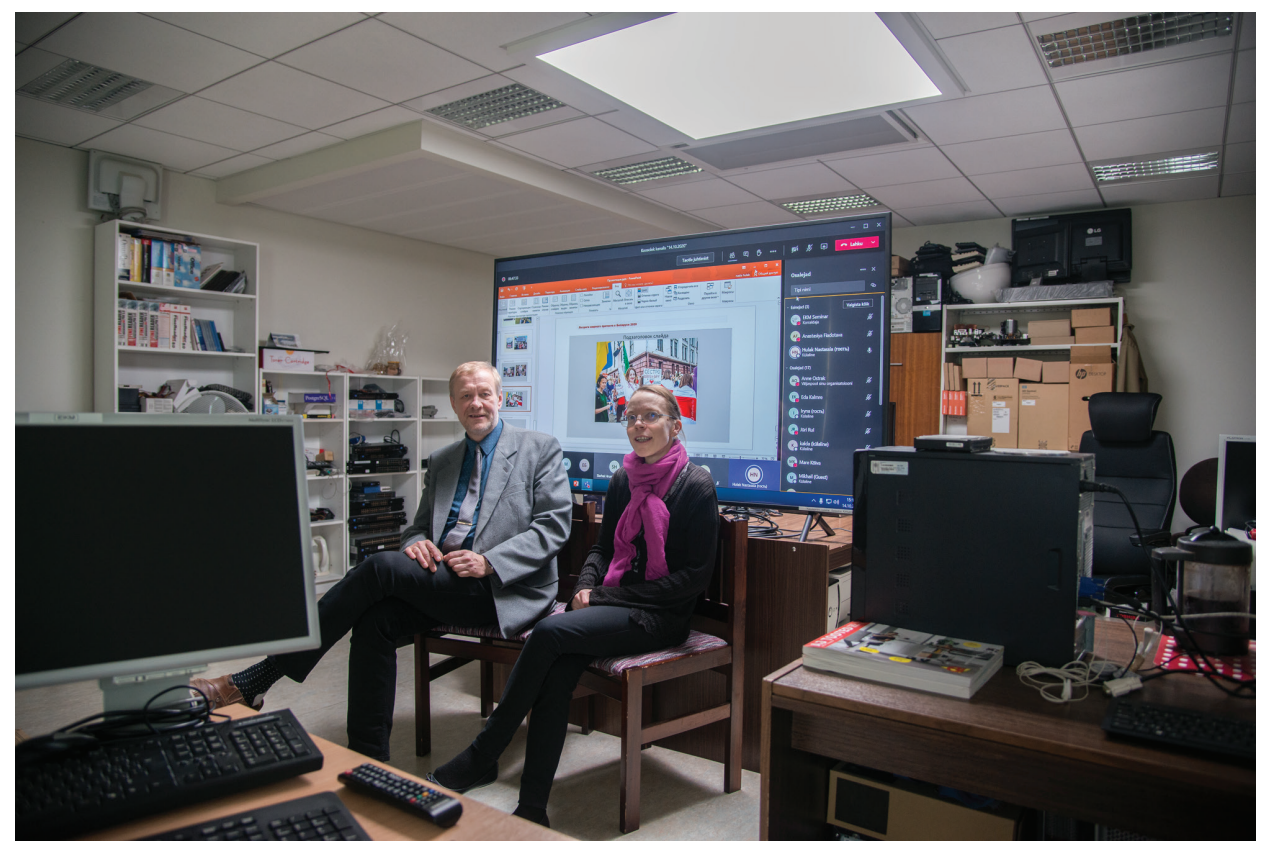

Maris Kuperjanov and Jüri Rui, who took responsibility for the technical side of the seminar. Photograph by Alar Madisson 2020. 
as a work of protest folklore: The story of one song" revolved around the use of popular "Kupalinka" song in Belarusian protests both inside the country and by Belarusian diaspora in other countries. Hrynevich also reflected on the ambiguous status of the song on the borderline between folk and authored work of art. The final paper of the session titled "Protest games' as digital folklore and a form of civil activism" was presented by Mikhail Fiadotau. The author provided a historical overview of mainstream and amateur video games that belong to the field of political discourse, and of the role of these games in civil activism.

The seminar panels were followed by a discussion and reflections on the multifaceted nature of folk narratives and practices. The presenters and listeners mentioned the rich variety of topics and theoretical concepts covered by the participants, and agreed on the future collaborative research activities. Tatsiana Valodzina, one of the seminar co-conveners, announced the publication of the edited volume of Фольклор и фбольклористика: Взгляд из Беларуси и Эстонии (Folklore and folkloristics: Belarusian and Estonian perspectives), which is due in November 2020. The volume features the papers by Estonian and Belarusian scholars that were discussed during the previous "Mission Possible" seminars and conferences. The seminar concluded with the hope that alongside online meetings it will be possible to organize face-to-face academic events in the coming months.

\section{Anastasiya Fiadotava}

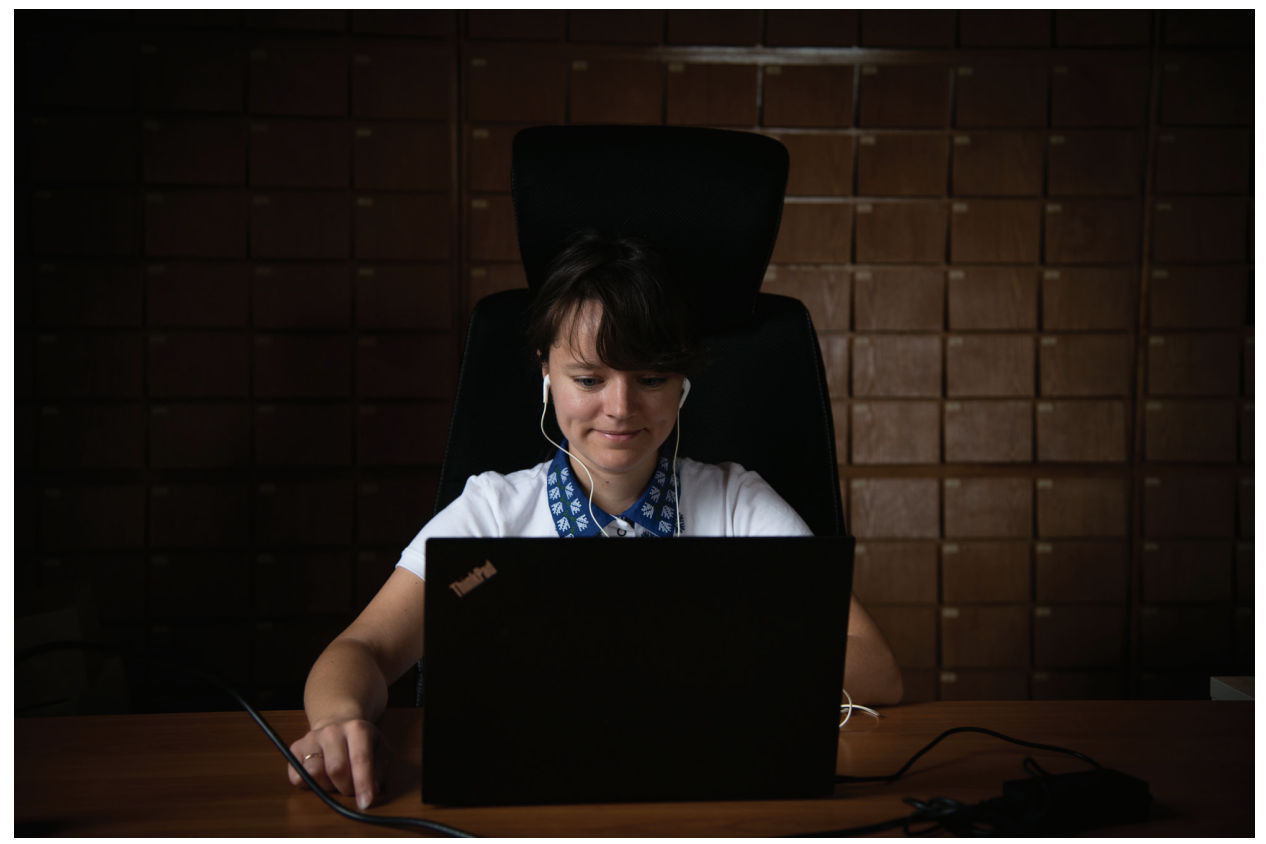

Anastasiya Fiadotava, one of the seminar organizers. Photograph by Alar Madisson 2020. 


\section{Notes}

1 The seminar was supported by the research project EKM 8-2/20/3, the joint project of the Department of Folkloristics of the ELM and the Centre of Studies of Belarusian Culture, Language and Literature of the National Academy of Sciences of Belarus, "Folklore, Religiosity, Language: Transcultural and vernacular aspects", and the Centre of Excellence in Estonian Studies (TK 145).

${ }^{2}$ Namitka is a long piece of fabric that East Slavic women used to wrap around their heads. 


\title{
BOOK REVIEWS
}

\section{SLAVIC ARBORETUM IN THE LIGHT OF ETHNOLINGUISTICS}

\author{
Tatiana Agapkina 2019. Derev'ia v slavianskoi narodnoi \\ traditsii: Ocherki. Moscow: Indrik. 656 pp. In Russian.
}

The year 2019 saw the publication of an ethnolinguistic ${ }^{1}$ monograph by Tatiana Agapkina, Derev'ia v slavianskoi narodnoi traditsii: Ocherki (Trees in the Slavic Folk Tradition: Essays), dedicated to the ethnobotanical fragment of the Slavic traditional culture. The book had been awaited by the academic humanitarian scholars and readers for a long time: the author started to publish her first articles on the mythopoetic dimensions of trees, their role in the folk beliefs system and their symbolism already in the mid-1990s. Some 'portraits' were included in the fundamental five-volume dictionary of Slavic antiquities

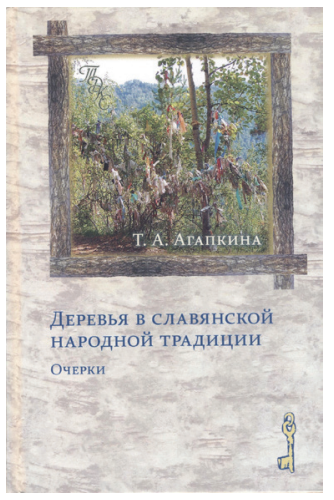
(Agapkina 1999, 2009, 2012; Agapkina \& Usacheva 1995); more detailed versions of these articles appeared in journals and collected works (Agapkina 1996, 1998). T. Agapkina belongs among scientists for whom the theme they study is always linked with the publication of a fundamental monograph (Agapkina 2002, 2010), so the publication of her most recent work dedicated to the Slavic arboretum in ethnolinguistic interpretation is quite logical.

In the introduction, which precedes two sections of the book, T. Agapkina presents the analytical apprehension of her earlier studies, including an analysis of the procedures employed in the descriptions of specific realities according to a certain scheme familiar to ethnolinguists who study demonology (Vinogradova et al. 1989) or, following A. Gura, animals (Gura 1997). These methods are specific to her earlier studies. According to T. Agapkina, adherence to the scheme in drawing a tree 'portrait' frequently brings about duplication of the data that rely on a superordinate term; therefore she makes a formal retreat from this principle in the book under current comment (pp. 17-18). However, the exposition of real, ontological and 'cultural' properties of trees, which precedes the principal part of the monograph, still contains a scheme of a kind, because such a tool allows not only to classify components of the Slavic arboretum in its entire system, but also to see mechanisms of selection and the extent of symbolization of their characteristics.

The ethnocultural data of trees in Slavic traditional cultures are so extensive and manifold that the author has to apply many restrictions. Every ethnolinguistic study urges covering of many spheres of spiritual and material culture, but trees are exceptionally rich in interconnections. In the monograph, the restrictions are introduced at the very beginning. The author states that the parts of trees, such as trunks, branches, fruits, etc., are not specially investigated (though apples and nuts are described to a certain extent). The reduced choice of the material influences the very list of the trees studied (the portrait of a birch is not included in the gallery), the rejection of several mythological topics, ritual acts and complexes (wedding customs), and the set of symbolic notions 
(the tree of life, the tree of knowledge). Agapkina's self-restrain, laconism, and precision can be traced through the whole monograph. It shows in her stylistics: the author often resorts to enumeration and concise description of either the principle properties of trees or the themes and plots connected with the Slavic arboretum. Types of fir tree decorations on the day when a conscript is given a send-off (pp. 90-91), folklore genres related to the theme of the continuation of human life in a tree (pp. 527-528), the conclusion and final ideas, as well as many other things are presented in such a shortened, 'epitomic' way, as T. Agapkina defines it.

Vegetative portraits presented in the first section are based on the classifying properties of trees briefly described in the chapter on classification. A set of properties for each tree, and, what is dominant, their hierarchy, are very different regarding the degree of their involvement in various spheres of traditional culture. It can be said that the tree leads the author and dictates the structure of the article or the 'portrait'. The gallery of portraits begins with the oak, the main representative of the 'world tree' (Toporov 2011) and the tree as such, and ends with the apple tree, in the mythological image of which fruitful and feminine symbols dominate. Essays are different by their length, ranging from very detailed ones (dedicated to oaks, fir trees, thorny trees, and bushes) to quite short ones dedicated to maples, sycamore maples, and ash trees. The 'portraits' also differ by their structure and availability (or absence) of a final generalization that concludes the portrait of a tree. The main and most outstanding properties of a tree, real as well as symbolic ones, show up in every essay, as well as in the most relevant folklore and ritual spheres where a tree is featured. In accordance with that, in every essay-portrait rubrics and subheadings are given, some peculiarities of the tree are distinguished, as well as its place in a certain folklore genre or in a specific ritual complex. Even the technical dressing of such diversified descriptions of trees presents a considerable difficulty. Various techniques are employed in the book: letter spacing, italics, semi-boldface italics, etc.

In the first section the author permanently makes comparisons, either explicit or implicit, which is the most important procedural principle. Due to this methodology, properties of a tree and its place in phraseology in the folklore and rites of every Slavic culture become clearer. T. Agapkina, as it were, occasionally returns to some facts and reminds her readers what they have already learnt. For instance, when describing the cult character of fir trees, she returns to similar characteristics of the oak. Comparison and differentiations assume opposition, such as real-symbolic, for example. The quaking aspen as a plant is more connected with demonology (symbolic properties), while fruiters as a whole manifest predominantly real, not symbolic properties, etc. When collating mytho-poetic images of trees, the author transcends the borders of the Slavic world: for some trees parallels from Baltic, German, Finno-Ugric, and other cultures are given.

In the second section of her work, T. Agapkina offers another, broader perspective of the study: she proceeds from the spheres of traditional culture where trees are invoked. The section begins with a detailed analysis of the 'world tree', which involves "various spheres of macrocosm" in interaction and exerts influence on the entire mythology of trees (p. 391). The universality of this image and many-sidedness of its expressions (notions of the centre, of the vertical, and of the beginning) help to explain contradictory properties of every single tree. Here T. Agapkina is striving to provide generalizations: 
she writes about classes of phenomena, about their parallelisms. For instance, she demonstrates the connection of the arboretum with all mythological characters, a rollcall of humaniform and vegetative spheres as well as demonstrates the systemic role of trees in funeral-commemorative rites. T. Agapkina has succeeded in connecting and organizing very dissimilar facts and presents them in general, at the same time drawing the reader's attention to important and interesting details.

Although it is evident from what was written above, I would like to emphasize that T. Agapkina introduces a whopping amount of material into scientific discourse. She quotes practically all folklore genres: riddles, calendric and wedding songs, lamentations, charms, proverbs, wishful clichés, aetiological legends, idioms, and many other things. Also hagiographical descriptions and historical records are used, not to mention the impressive ethnographic corpus of data. The bibliography comprises over 1,200 sources and studies, and the index covers more than 80 pages. Literature includes the rarest Slavic publications as well as frequent regional ones that are hard to access. These publications are of extreme value. No doubt it is the result of consistent work with sources. For decades, even if she did research work on other topics, T. Agapkina collected material for this particular book. In fact, its index is a glossary of folk culture, which helps not only to work with the book, but it can be used as a guide for different investigations by other researchers. At the very end of the book, the author defines, in her own laconic style, three directions of further studies of the Slavic arboretum. These directions are: to explore the portraits of the trees that are missing in the monograph, to perform an analysis of the tree as a cultural concept, and to continue studies of the real peculiarities of trees with botanical types taken into due account.

The book urges its readers to ponder over the material presented to them, to compare it with ethno-botanical and other data, to look for parallels. As a specialist in Bulgarian ethnography, I noticed certain lexical, folkloric or ritual details which could be added to the portraits of the trees. For example, the Bulgarian popular and religious rite performed in front of "The Holy Virgin Golden Apple" icon could be mentioned. On Saturday, in the fifth week of the Lent, young women eager to conceive or childless married couples bring red apples over to the church. Perhaps this rite and other details are not included in the book, due to limits imposed on its volume.

This monograph is definitely interesting and useful for humanitarians of various specialties. Considering its vast scope, cohesive structure and logic of study, it can serve as a model for young researchers. This book will facilitate further studies in the sphere of the complex discipline of ethnolinguistics. It can serve as a methodological pattern for the ethnolinguistic investigation of similar ethnobotanical and very different folkcultural themes.

\section{Irina Sedakova}

\section{Note}

1 On Moscow Ethnolinguistic School founded by Nikita I. Tolstoi see Tolstoi \& Tolstaia 2013. For a classic example of an ethnolinguistic study see Tolstaia 2001 [2005]. 


\section{References}

Agapkina, Tatiana 1996. Simvolika derev'ev v traditsionnoi kul'ture slavian: osina (opyt sistemnogo opisaniia). [Symbolism of Trees in the Traditional Slavic Culture: The Asp (An Attempt of a Systematic Depiction).] Kodovi slovenskikh kultura. Vol. 1. Belgrade: Clio, pp. 7-22. Available at https://ru.scribd.com/doc/300151594/ Kodovi-Slovenskih-Kultura-Biljke?fbclid=IwAR1o-PUO1o4zzLMnaQ3vPiZeWno rwAM33JiISp8iBVOlxlUzk14JwnTyt7A, last accessed on 17 November 2020.

Agapkina, Tatiana 1998. Mifologiia derev'ev v traditsionnoi kul'ture slavian: leshchina (Corylus avellana). [Mythology of Trees in the Slavic Traditional Culture: Corylus avellana.] Studia mythologica Slavica, Vol. 1, pp. 183-194. Available at http:// sms.zrc-sazu.si/pdf/01/SMS_01_Agapkina.pdf, last accessed on 17 November 2020.

Agapkina, Tatiana 1999. Derevo kul'tovoe. [A Cult Tree.] In: Nikita Tolstoi (ed.) Slavianskie drevnosti: etnolingvisticheskii slovar'. Vol. 2. Moscow: Mezhdunarodnye otnosheniia, pp. 67-70. Available at https://vk.com/doc-83903602_438147196?has $\mathrm{h}=23372 \mathrm{cb} 20 \mathrm{~d} 6 \mathrm{c} 57 \mathrm{~b} 799$, last accessed on 17 November 2020 .

Agapkina, Tatiana 2002. Mifopoeticheskie osnovy slavianskogo narodnogo kalendaria: Vesenne-letnii tsikl. [Mytho-poetic Fundamentals of the Slavic Folk Calendar: Spring and Summer Period.] Moscow: Indrik. Available at https://inslav.ru/images/ stories/pdf/2002_Agapkina_\%20Mifopoeticheskie_osnovy_slav\%27anskogo_ narodnogo_kalendar\%27a_Vesenne-letnij\%20_cikl.pdf, last accessed on 17 November 2020.

Agapkina, Tatiana 2009. Riabina. [Sorbus.] In: Nikita Tolstoi (ed.) Slavianskie dreunosti: etnolingvisticheskii slovar'. Vol. 4. Moscow: Mezhdunarodnye otnosheniia,pp. 514519.

Agapkina, Tatiana 2010. Vostochnoslavianskie lechebnye zagovory v sravnitel'nom osveshchenii: Siuzhetika i obraz mira. [East Slavic Healing Charms in a Comparative Light.] Moscow: Indrik. Available at https://inslav.ru/images/ stories/pdf/2010_Agapkina_Zagovory.pdf, last accessed on 17 November 2020.

Agapkina, Tatiana 2012. Iasen'. [Ash.] In: Nikita Tolstoi (ed.) Slavianskie drevnosti: etnolingvisticheskii slovar'. Vol. 5. Moscow: Mezhdunarodnye otnosheniia, pp. 637-538. Available at https://vk.com/doc35528094_464711466?hash=48064 84bb6725d6c54, last accessed on 17 November 2020.

Agapkina, Tatiana 2019. Derev'ia v slavianskoi narodnoi traditsii: Ocherki. [Trees in the Slavic Folk Tradition: Essays.] Moscow: Indrik.

Agapkina, Tatiana \& Usacheva, Valeria 1995. Buzina. [Elder.] In: Nikita Tolstoi (ed.) Slavianskie drevnosti:etnolingvisticheskii slovar'. Vol. 1. Moscow: Mezhdunarodnye otnosheniia, pp. 267-270. Available at https://vk.com/doc2674442_214184891?ha sh=bda46c1fec73e4bbe7, last accessed on 17 November 2020.

Gura, Aleksandr 1997. Simvolika zhivotnykh v slavianskoi narodnoi traditsii. [Symbolism of the Animals in the Slavic Folk Tradition.] Moscow: Indrik. Available at https:// inslav.ru/images/stories/pdf/1997_Gura.pdf, last accessed on 17 November 2020.

Tolstaia, Svetlana 2001 [2005]. Rites for Providing and Stopping Rain in Slavonic Folk Tradition. Cosmos, Vol. 12, No. 2, pp. 179-195. 
Tolstoi, Nikita \& Tolstaia, Svetlana 2013. Slavianskaia etnolingvistika: Voprosy teorii. [Slavic Ethnolinguistics: Theoretical Questions.] Moscow: Institut slavianovedeniia RAN. Available at https://inslav.ru/publication/tolstoy-n-itolstaya-s-m-slavyanskaya-etnolingvistika-voprosy-teorii-m-2013, last accessed on 17 November 2020.

Toporov, Vladimir 2010. Mirovoe derevo: Universal'nye znakovye sistemy. [World Tree: Universal Sign Systems.] Vol. 1. Moscow: Rukopisnye pamiatniki Drevnei Rusi.

Vinogradova, Liudmila 1989. Skhema opisaniia mifologicheskikh personazhei. [Scheme of Description of the Mythological Beings.] In: Liudmila Vinogradova \& Nataliia Zlydneva \& Svetlana Tolstaia (eds.) Materialy k VI Mezhdunarodnomu kongressu po izucheniiu stran Iugo-Vostochnoi Evropy. Problemy kul'tury. Sofiia, 30.VIII.89 6.IX.89. Moscow: Institut slavianovedeniia i balkanistiki RAN, pp. 78-85. Available at https://inslav.ru/images/stories/pdf/1989_Materialy_k_VI_kongressu_ Problemy_kul\%27tury.pdf, last accessed on 17 November 2020. 


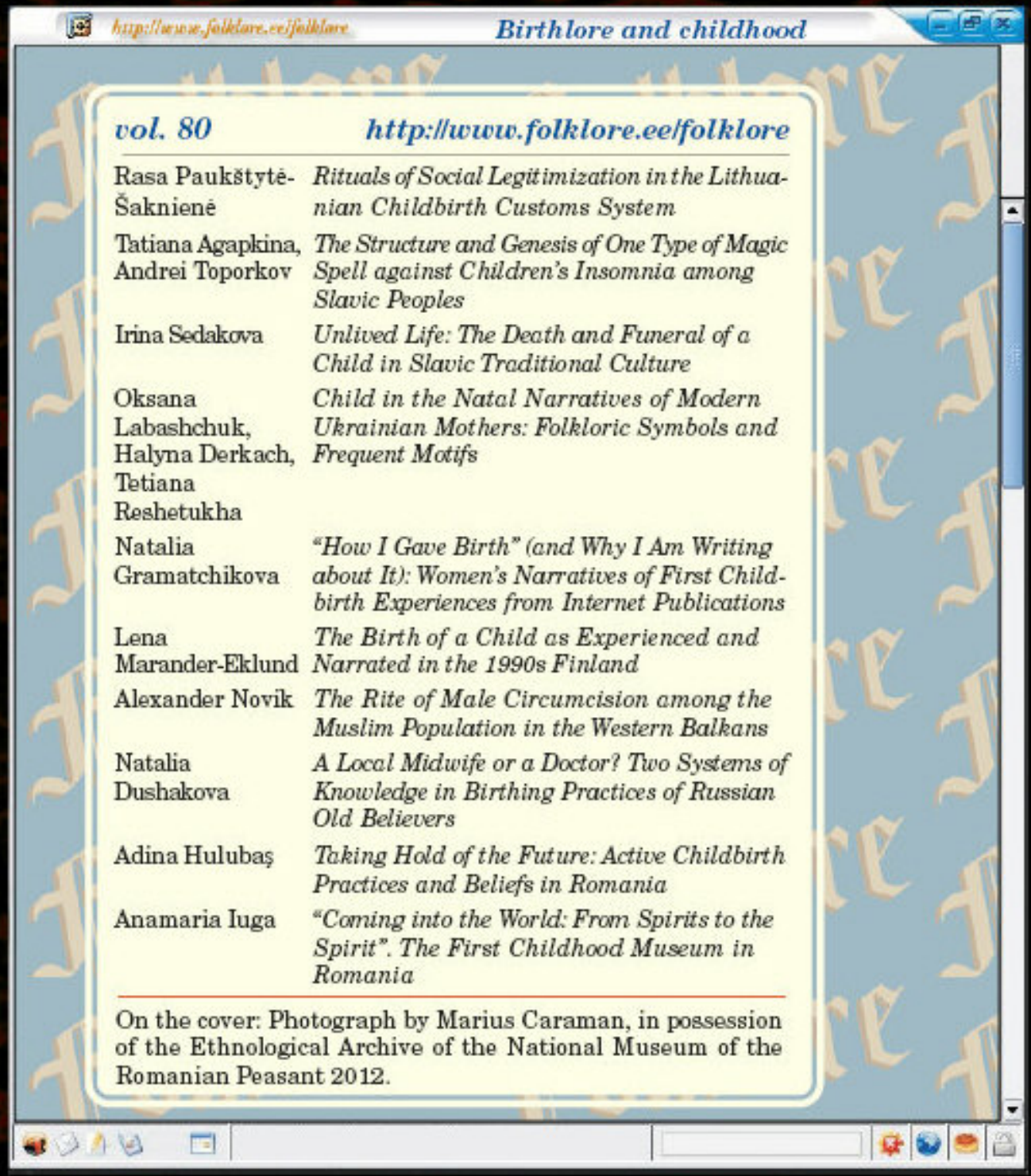

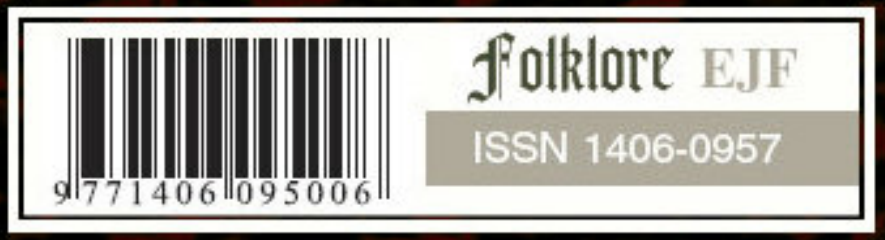

